\title{
Radionuclide Release from Spent Fuel Under Geologic Disposal Conditions: An Overview of Experimental and Theoretical Work Through 1985
}
P. W. Reimus
S. A. Simonson

April 1988

Prepared for the U.S. Department of Energy under Contract DE-AC06-76RLO 1830

Pacific Northwest Laboratory Operated for the U.S. Department of Energy by Battelle Memorial Institute 


\section{DISCLAIMER}

This report was prepared as an account of work sponsored by an agency of the United States Government. Neither the United States Government nor any agency thereof, nor Battelle Memorial Institute, nor any or their employees, makes any warranty, expressed or implied, or assumes any legal liability or responsibility for the accuracy, completeness, or usefuiness of any information, apparatus, product, or process disclosed, or represents that its use would not intringe privately owned rights. Reference herein to any specific commercial product, process, or service by trade name, trademark, manufacturer, or otherwise does not necessarily constitute or imply its endorsement, recommendation, or favoring by the United States Government or any agency thereof, or Battelle Memorial Institute. The views and opinions of authors expressed herein do not necessarity state or reflect those of the United States Government of any agency thereof, or Battelfe Memorial Institute.

\section{PACIFIC NORTHWEST LABORATORY operated by BATTELLE MEMORIAL. INSTITUTE for the UNITED STATES DEPARTMENT OF ENERGY under Contract DE-AC06-76RLO 1830}

\begin{tabular}{|c|c|}
\hline \multicolumn{2}{|c|}{ Printed in the United States af America } \\
\hline \multirow{2}{*}{\multicolumn{2}{|c|}{$\begin{array}{c}\text { Available from } \\
\text { National Technical Information Service }\end{array}$}} \\
\hline & \\
\hline \multirow{3}{*}{\multicolumn{2}{|c|}{$\begin{array}{c}\text { United Stales Depariment of Commerce } \\
5285 \text { Port Royal Road } \\
\text { Springfield, Virginia } 22161\end{array}$}} \\
\hline & \\
\hline & \\
\hline \multirow{2}{*}{\multicolumn{2}{|c|}{$\begin{array}{l}\text { NTIS Price Codes } \\
\text { Micrafiche A01 }\end{array}$}} \\
\hline & \\
\hline \multicolumn{2}{|c|}{ Printed Copy } \\
\hline & Price \\
\hline Pages & Codes \\
\hline $001-025$ & $\mathrm{AOZ}$ \\
\hline $026-050$ & $\mathrm{~A} 03$ \\
\hline $051-075$ & $A 04$ \\
\hline $076-100$ & $\mathrm{~A} 05$ \\
\hline $101-125$ & $A D B$ \\
\hline 126.150 & A07 \\
\hline 151.175 & AOS \\
\hline $176-200$ & $A 09$ \\
\hline $201-225$ & $A 010$ \\
\hline $226-250$ & A011 \\
\hline $251-275$ & A012 \\
\hline $276-300$ & A013 \\
\hline
\end{tabular}


PNL -5551

UC -510

RADIONUCLIDE RELEASE FROM SPENT FUEL UNDER GEOLOGIC DISPOSAL CONDITIONS: AN OVERVIEW OF EXPERIMENTAL AND THEORETICAL WORK THROUGH 1985

P. H. Reimus

S. A. Simonson

April 1988

Prepared for the U.S. Department of Energy under Contract DE-ACD6-76RLO 1830

Pacific Northwest Laboratory

Richland, Washington 99352 



\section{FOREWORD}

This overview of existing experimental and theoretical work on radionuclide release from spent fuel was completed in November 1985. Thus, any work on this topic that was published after that time is not reviewed in this document. As a result of this review, an informal library of literature on radionuclide release from spent fuel was created at Pacific Northwest Laboratory. This library will be maintained by the Waste Package Program of the Salt Repository Project. 


\section{SUMMARY}

This report presents an overview of experimental and theoretical work on radionuclide release from spent fuel and uranium dioxide $\left(\mathrm{UO}_{2}\right)$ under geologic disposal conditions. The purpose of the report is to provide a source book of information that $c$ an be used to develop models that describe radionuclide release from spent fuel waste packages. Modeling activities of this nature will be conducted within the Waste Package Program (WPP) of the Department of Energy's Salt Repository Project (SRP).

The topics discussed in this report include:

- experimental methods for investigating radionuclide release

- how results have been reported from radionuclide release experiments

- theoretical studies of $\mathrm{UO}_{2}$ and actinide solubility

- results of experimental studies of radionuclide release from spent fuel and $\mathrm{UO}_{2}$ (i.e., the effects of different variables on radionuclide release)

- characteristics of spent fuel pertinent to radionuclide release

- status of modeling of radionuclide release from spent fuel. Appendix A presents tables of data from spent fuel radionuclide release experiments. These data have been digitized from graphs that appear in the literature. An annotated bibliography of literature on spent fuel characterization is provided in Appendix B.

Based on what has been learned in spent fuel and $\mathrm{UO}_{2}$ radionuclide release studies, a complete model describing the release of radionuclides from spent fuel should include the following submodels:

- an instant release submodel describing the rate of release of soluble radionuclides (e.g., cesium-134, cesium-137, iodine-129, and possibly technetium-99) that have accumulated in the fuel-cladding gap and at the grain boundaries of the spent fuel (the first surfaces to come in contact with leachant) 
- a kinetic submodel describing the rate of degradation (i.e., oxidation and dissolution) of the spent fuel matrix, which describes the rate at wich many radionuclides become unbound from the spent fuel and available for transport

- a post-release submodel, which describes the accumulation of radionuclides in solution, the formation of precipitates, colloids, and a)teration phases, and the constraints on these processes

- a mass transfer submodel, which describes the transport of the radionuclides away from the spent fuel according to the concentration of radionuclides in solution. 
The authors would like to thank Bill Kuhn and Don Bradley for their reviews of this document. Many thanks are due to Neal Myrick for his work in digitizing the data presented in Appendix $A$ and for his help in conducting the literature search. We thank Elsie Golding, Pat Styris, and Tanya Longaker for their assistance in typing the bibliographies. Thanks are due to Andrea McMakin for her editorial reviews and assistance in preparing this document. The assistance provided by Pacific Northwest Laboratory's word processing and graphics staff were also greatly appreciated. This document was prepared for the Office of Nuclear Waste Isolation (ONWI) as part of the Department of Energy's Salt Repository Project (SRP). The work was supported by the Department of Energy under Contract OE-AC06-76RLO 1830. 
-

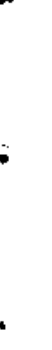


CONTENTS

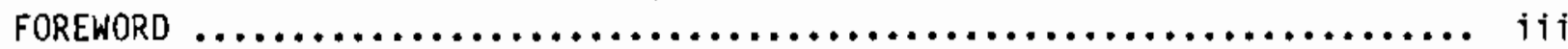

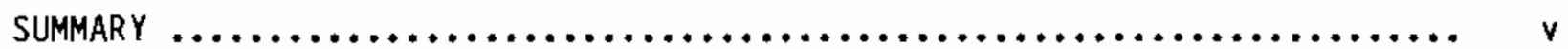

ACKNOWLEDGMENTS $\ldots \ldots \ldots \ldots \ldots \ldots \ldots \ldots \ldots \ldots \ldots \ldots \ldots \ldots \ldots \ldots \ldots \ldots \ldots \ldots \ldots \ldots$

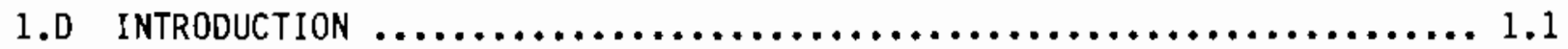

2.0 EXPERIMENTAL METHODS FOR INVESTIGATING RADIONUCLIDE RELEASE ....... 2.I

2.1 NON-ACCELERATED RADIONUCLIDE RELEASE TESTS $\ldots \ldots \ldots \ldots \ldots \ldots \ldots \ldots . \ldots$

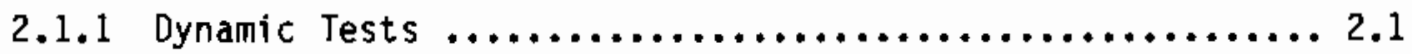

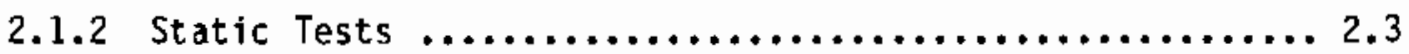

2.2 ACCELERATED DISSOLUTIDN $\ldots \ldots \ldots \ldots \ldots \ldots \ldots \ldots \ldots \ldots \ldots \ldots \ldots \ldots \ldots \ldots \ldots \ldots \ldots \ldots$

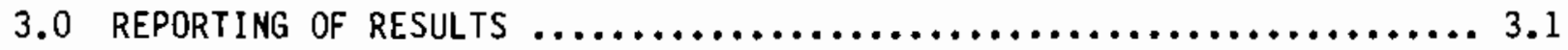

4.D STUDIES OF RADIONUCLIDE RELEASE FROM URANIUM DIOXIDE

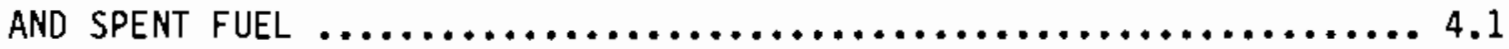

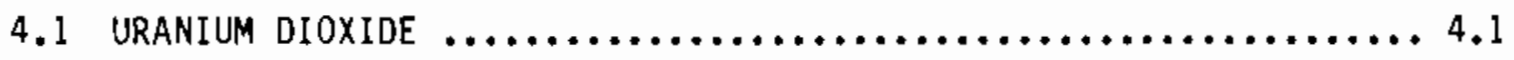

4.2 SPENT FUEL $\ldots \ldots \ldots \ldots \ldots \ldots \ldots \ldots \ldots \ldots \ldots \ldots \ldots \ldots \ldots \ldots \ldots \ldots \ldots . \ldots \ldots$

4.3 SIMULATED SPENT FUEL $\ldots \ldots \ldots \ldots \ldots \ldots \ldots \ldots \ldots \ldots \ldots \ldots \ldots \ldots \ldots \ldots \ldots$

5.0 THEORETICAL STUDIES OF URANIUM AND ACTINIDE SOLUBILITY $\ldots \ldots \ldots \ldots \ldots . .1$

6.0 RESULTS FROM EXPERIMENTAL STUDIES OF RADIONUCLIDE RELEASE FROM

URANIUM DIOXIDE AND SPENT FUEL $\ldots \ldots \ldots \ldots \ldots \ldots \ldots \ldots \ldots \ldots \ldots \ldots \ldots \ldots \ldots .1$

6.1 GENERAL TRENDS OF RELEASE OF VARIOUS RADIONUCLIDES $\ldots \ldots \ldots \ldots \ldots .1$

6.1 .1 Release of Cesium and Iodine $\ldots \ldots \ldots \ldots \ldots \ldots \ldots \ldots \ldots . \ldots . \ldots$

6.1 .2 Release of Other Fission Products and Actinides ........ 6.3

6.2 EFFECT OF SOLUTION CDMPOSITION AND CHEMICAL SPECIES ON

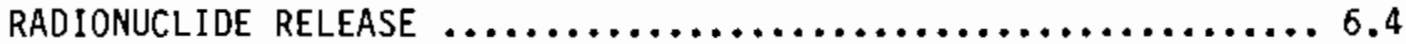

6.3 EFFECT OF TEMPERATURE ON RADIONUCLIDE RELEASE $\ldots \ldots \ldots \ldots \ldots \ldots \ldots .7$

6.4 EFFECT OF pH ON RADIONUCLIDE RELEASE $\ldots \ldots \ldots \ldots \ldots \ldots \ldots \ldots \ldots \ldots .7$ 
6.5 EFFECT OF OXYGEN CONCENTRATION AND En ON

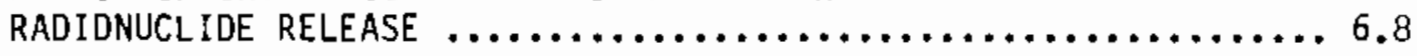

6.6 EFFECT OF FUEL IRRADIATION HISTORY ON

RADIONUCLIDE RELEASE $\ldots \ldots \ldots \ldots \ldots \ldots \ldots \ldots \ldots \ldots \ldots \ldots \ldots \ldots, 6,12$

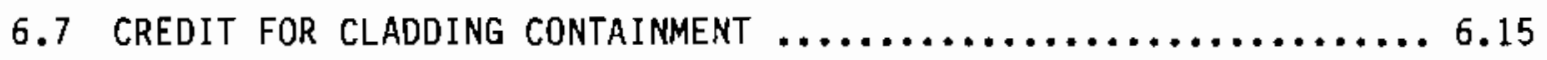

6.8 MECHANISMS OF OXIDATION AND DISSOLUTION $\ldots \ldots \ldots \ldots \ldots \ldots \ldots \ldots, 6.17$

6.9 EFFECT OF RADIOLYSIS ON RADIONUCLIDE RELEASE $\ldots \ldots \ldots \ldots \ldots \ldots 6.20$

6.1D EFFECT OF WASTE PACKAGE CONSTITUENTS ON

RADIONUCLIDE RELEASE $\ldots \ldots \ldots \ldots \ldots \ldots \ldots \ldots \ldots \ldots \ldots \ldots \ldots \ldots \ldots \ldots \ldots \ldots \ldots, 6.22$

6.11 SORPIION, PRECIPITATION, COLLOIDS, AND THE FORMATION OF

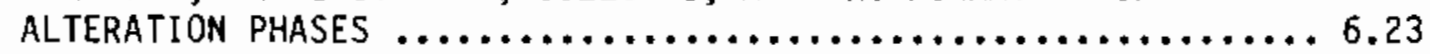

7.0 CHARACTERISTICS OF SPENT FUEL PERTINENT TO RADIONUCLIDE RELEASE $\ldots \ldots 7.1$

8.0 STATUS OF MODELING OF RADIONUCLIDE RELEASE FrOM SPENT FUEL $\ldots \ldots \ldots \ldots .1$

9.0 CONCLUSIONS REGARDING MODELING OF RADIONUCLIDE RELEASE

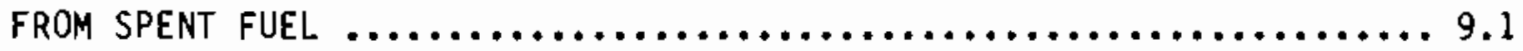

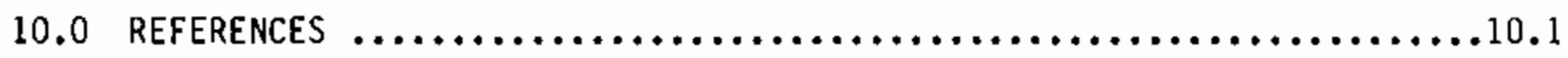

APPENDIX A: DIGITIZED DATA SETS OF SPENT FUEL RELEASE $\ldots \ldots \ldots \ldots \ldots \ldots$... 1

APPENDIX B: ANNOTATED BIBLIOGRAPHY OF LITERATURE ON SPENT FUEL/ $\mathrm{UO}_{2}$

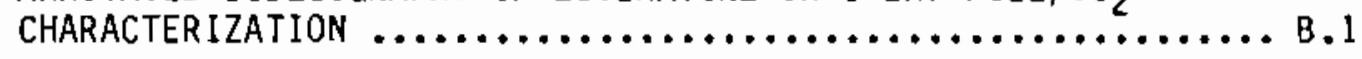




\section{FIGURES}

1 Potential $\mathrm{pH}$ Diagrams for the Uranium/Water System at (a) $25^{\circ} \mathrm{C}$,

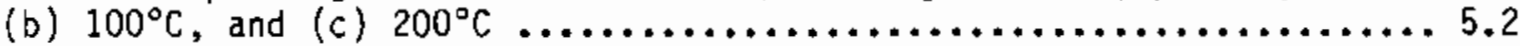

2 Maximum Uranium Solubilities in Brine Ground Water $\ldots \ldots \ldots \ldots \ldots \ldots . . .4$

3 Fractional Release Rate of Various Radionuclides from $28.0 \mathrm{MWd} / \mathrm{kg} U$ Spent Fuel in Deionized Water at $25^{\circ} \mathrm{C} \ldots \ldots \ldots \ldots \ldots . \ldots 6$

4 Fractional Release of ${ }^{137} \mathrm{Cs}$ from $28 \mathrm{MWd} / \mathrm{kg} \mathrm{U}$ Spent Fuel in Various Solutions at $25^{\circ} \mathrm{C} \ldots \ldots \ldots \ldots \ldots \ldots \ldots \ldots \ldots . \ldots . \ldots . \ldots$

5 Fractional Release Rate of ${ }^{244} \mathrm{Cm}$ from $28.0 \mathrm{MHd} / \mathrm{kg} \mathrm{u}$ Spent Fuel in Various Solutions at $25^{\circ} \mathrm{C} \ldots \ldots \ldots \ldots \ldots \ldots \ldots \ldots \ldots \ldots . \ldots \ldots$

6 Fractional Release Rate of Uranium from Unirradiated $\mathrm{UO}_{2}$ Pellets as a Function of $\mathrm{pH} \ldots \ldots \ldots \ldots \ldots \ldots \ldots \ldots \ldots \ldots \ldots \ldots \ldots . \ldots \ldots$

7 Uranium Solution Concentration as a Function of $\mathrm{pH}$ at $23^{\circ} \mathrm{C} \ldots \ldots \ldots . .6$

8 Fractional Release Rate of ${ }^{90} \mathrm{Sr}$ from $28.0 \mathrm{MHd} / \mathrm{kg}$ U Spent Fuel Under Reducing and 0xidizing Conditions ............................

9 Fractional Release Rate of ${ }^{137} \mathrm{Cs}$ from $28.0 \mathrm{MWd} / \mathrm{kg} \mathrm{U}$ Spent Fuel Under Reducing and Oxidizing Conditions ..............6.11

10 Fractional Release Rate of ${ }^{137} \mathrm{Cs}$ from Spent Fuels with Burnups of 9.D, 28.0, and $54.5 \mathrm{MWd} / \mathrm{kg} \mathrm{U}$ in Deionized

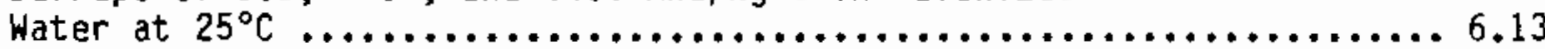

11 Fractional Release Rate of ${ }^{137}$ Cs from Spent Fuels with Moderate and High Power Ratings

12 Fraction of Uranium Inventory in Solution for $31 \mathrm{MWd} / \mathrm{kg} U$ Spent PWR Fuel with Various $\mathrm{Cladding} \mathrm{Defects} \mathrm{in} \mathrm{Yucca} \mathrm{Mountain}$ Well Water at $25^{\circ} \mathrm{C}$

13 Fraction of ${ }^{137} \mathrm{Cs}$ Inventory is Solution for $31 \mathrm{MWd} / \mathrm{kg} \mathrm{U}$ PWR Spent Fuel with Various Cladding Defects in Yucca Mountain Well Water at $25^{\circ} \mathrm{C}$

14 Dissolution Mechanisms for $\mathrm{UO}_{2}$ in Deionized Water .................... 6.19

15 Reaction Scheme for the Anodic 0xidation of $\mathrm{U}_{2} \ldots \ldots \ldots \ldots \ldots \ldots \ldots . \ldots . \ldots . \ldots$

16 Radionuclide Release from $\mathrm{UO}_{2}$ Fuel in water, Oxidizing Conditions 


\section{TABLES}

1 Studies of Uranium Release from $U 0_{2} \ldots \ldots \ldots \ldots \ldots \ldots \ldots \ldots \ldots \ldots \ldots, \ldots \ldots \ldots$

2 Studies of Radionuclide Release from Spent Fuel $\ldots \ldots \ldots \ldots \ldots \ldots \ldots . . .10$

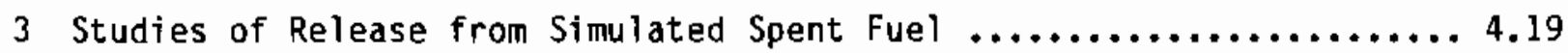




\subsection{INTRODUCTION}

The Waste Package Program (WPP) at Pacific Northwest Laboratory (PNL) is being conducted for the Department of Energy's Salt Repository Project (SRP) to provide technical support in assessing the performance of nuclear waste packages in a conceptual geologic repository for high-level waste. The WPP includes a number of experimental activities to investigate the degradation of proposed waste package components and associated behavior that pertain to licensing a repository. These activities address the problem of demonstrating that waste packages can meet the criteria imposed by regulations such as the Nuclear Regulatory Commission (NRC) regulation 10 CFR 60 and the proposed Environmental Protection Agency (EPA) regulation 40 CFR 191.

The WPP includes a modeling task, which is intended to provide a close link between waste package experimentation and SRP performance assessment activities. The objective of WPP modeling is to develop and validate models that describe the behavior of waste package components under conditions expected in a geologic repository. These models can be easily incorporated by the SRP into a code such as the Waste Package Performance Assessment (WAPPA) code.

The predicted behavior of spent fuel in a geologic repository, after all other waste package barriers have failed (i.e., spent fuel in contact with ground water or brine), is of particular interest because commercial spent fuel is expected to be the major form of nuclear waste disposed in a repository. The release of radionuclides from spent fuel must be predicted to show compliance with the regulatory criteria cited above.

This document is intended to be a source book of information for future modeling efforts to be conducted within the WPP in the area of radionuclide release from spent fuel. It is intended to benefit both modelers and experimentalists who are involved in the assessment of spent fuel as a waste form.

The review is divided into several chapters. The first chapter (Chap* ter 2.0) describes the experimental methods that have been used to measure radionuclide release rates from spent fuel and uranium dioxide $\left(U D_{2}\right)$. The second chapter (Chapter 3.0) describes the various ways that release and 
release rates have been reported. A summary of all the radionuclide release studies that have been conducted on spent fuel, $\mathrm{UO}_{2}$, and simulated spent fuel under geologic disposal conditions is given in Chapter 4.0. This chapter contains tables that sumarize the conditions and parameters studied in each of the experiments. Chapter 5.0 discusses theoretical studies of $\mathrm{UO}_{2}$ dissolution and solubility, which are considered important because the reactions of spent fuel are dominated by the chemistry of $\mathrm{UO}_{2}$. Chapter 6.0 compares the experimental results of the studies discussed in Chapter 4.0 with the theoretical predictions from the studies in Chapter 5.0. Chapter 7.0 contains a brief discussion of the characteristics of spent fuel that are expected to be important to radionuclide release. Chapter 8.0 discusses the status of modeling of radionuclide release from spent fuel. Conclusions regarding the modeling of radionuclide release from spent fuel are made in Chapter 9.0. Two appendices are provided: an appendix of tabular spent fuel release data taken from the literature, and an annotated bibliography of spent fuel characterization. 


\subsection{EXPERIMENTAL METHODS FOR INVESTIGATING RADIONUCLIDE RELEASE}

This chapter discusses the different types of test methods used in radionuclide release experiments. The test methods are divided into two major categories: non-accelerated and accelerated. Non-accelerated tests involve placing a waste form specimen in contact with a solution for a specified period of time without any interference from outside the system. As long as the waste form and solution remain in contact, they will approach a state of equilibrium with respect to each other. These tests are used to study dissolution kinetics, radionuclide release rates, solubility limits, and interactions of the waste form with other waste package barriers and/or the surrounding geology. In accelerated tests, an outside source of power (e.g., an electrical battery) is used to impose an unnatural driving force for reaction between the waste form and the solution. The source of power can generally be controlled to speed up, slow down, or reverse the reactions occurring in the system, which allows the experimentalist to collect data that are useful for deducing mechanisms of reactions. Because the imposed driving forces tend to keep the system from approaching equilibrium, however, it is difficult to study reaction rates and equilibrium conditions in accelerated tests.

\subsection{NON-ACCELERATED RADIONUCLIDE RELEASE TESTS}

Non-accelerated radionuclide release tests fall into two categories: dynamic tests and static tests. Discussions of variations of both types of tests and their objectives are given by Bradley, McVay and Coles (1980), McVay, Bradley and Kircher (1981), and Mendel (1982). Because data from different experiments are frequently difficult or impossible to compare, the Materials Characterization Center (MCC) at PNL has defined a series of standardized tests for nuclear waste forms (Mendel 1980, 1984a, 1984b). Most experimentalists in the United States now follow these standardized tests or modifications of them.

\subsubsection{Dynamic Tests}

Dynamic tests involve either 1) renewal of solution at specified time intervals or 2) continuous flow of solution past a waste form specimen. These tests generally simulate much higher flow rates than those expected in a 
geologic repository. Dynamic tests have been used mainly to study the effects of different variables on forward reaction rates or degradation rates of spent fuel or $\mathrm{UO}_{2}$. Because the solution is constantly renewed, dynamic tests are not suited for observing saturation effects, formation of thermodynamically stable alteration phases, and long-term interactions with waste package constituents that are important at low flow rates. For this reason, most experimentalists have deemphasized or elfminated dynamic testing in their programs.

A brief review of the two types of dynamic tests is given below.

\subsubsection{Renewal of Solution in Batches (IAEA and Modified IAEA Tests)}

In 1971, Hespe proposed a standard test method for radionuclide release studies for the International Atomic Energy Agency (IAEA). In his procedure he specified a solution-volume-to-waste-form-surface-area ratio of $10 \mathrm{~cm}$. He also suggested a sampling/solution renewal frequency of once a day at the start of the experiment, weekly after the first week, monthly after eight weekly changeouts, and finaliy semi-annualiy after six monthly changeouts (Hespe 1971). Many experimentalists have modified this procedure by changing the volume-to-surface area ratio and/or the sampling frequency (generally limiting the changeout to no more than once per month). Some experimentalists have also circulated the solution rather than allow it to sit in static contact with the solid sample. These tests are relatively easy to conduct and do not require a complicated apparatus.

A disadvantage of the IAEA or modified IAEA tests (in addition to those disadvantages already mentioned for dynamic tests in general) is that dissolution kinetics can cause misleading interpretations of the data. For example, if the rate of dissolution of a given component is such that the solubility limit in the solution is reached within one day of contact with the waste form, then the release rate will appear to decrease as contact time with solution is increased. In IAEA tests, the release rate may appear to decrease with time because the same amount of material will be released over successively longer periods of time. Although this is an oversimplified example, it serves to show that rates of dissolution that vary with time and concentration can give rise to misleading results from IAEA tests. A more detailed discussion of this topic is given by Ogard and Bryant (1982). 


\subsubsection{Continuous Flow of Solution (Continuous Flow Tests)}

As the name implies, these tests are conducted with continuous flow of solution past the waste form. Since there is generally no recycling of solution, these tests are often called single-pass, continuous flow tests. Samples are taken periodically from the effluent stream.

As in the case of IAEA and modified IAEA tests (Section 2.1.1.1), misleading results can be obtained from continuous flow tests when the dissolution rate of the waste form varies with time and/or concentration. Generally, the release rate of a given component will be greater when the flow rate is higher because the steady-state concentration of a component near the surface of the waste form will decrease as the flow rate increases, which leads to a greater driving force for dissolution.

The continuous flow test was first used at Lawrence Livermore National Laboratory (Weed and Jackson 1979; Coles 1981), and it has been adopted by the MCC as leach test MCC-4 (Mendel 1980, 1984a, 1984b). This review of the 1iterature has revealed no published studies in which a continuous flow test was conducted on spent fuel.

\subsubsection{Static Tests}

The distinguishing feature of static tests is that the solution is never renewed. These tests simulate the no-flow or very low flow conditions that are expected in a geologic repository. These conditions allow experimentalists to observe saturation effects, the formation of alteration phases (i.e., precipitates and colloids), and interactions of the waste form constituents with the surrounding geology and failed engineered barriers if such materials are included in the test environment along with the waste form.

Some of the conditions used in static tests are sumarized below.

- Low temperature (less than $100^{\circ} \mathrm{C}$ ) with an intact waste form. This test is described by MCC leach test MCC-1 (Mendel 1980, 1984b). 
- High temperature and frequently at elevated pressures (hydrothermal conditions) with an intact waste form. These tests are generally carried out in autoclaves, and are described by MCC leach test MCC -2 (Mendel 1980, 1984b, 1985).

- Either of the above conditions with a crushed waste form. This test is described by MCC leach test MCC-3 (Mendel 1980, 1984a, 1984b).

- Any of the above conditions in the presence of geologic materials. This type of test is currently being incorporated as one of the standard MCC leach tests.

- Any of the above conditions in the presence of engineered barrier materials.

- Any of the above conditions in the presence of both geologic materials and engineered barrier materials. This type of test is currently being incorporated as one of the standard MCC leach tests.

- Any of the above conditions with the system being rocked rather than kept static.

The reader is referred to McVay, Bradley and Kircher (1981) for a discussion of some of the advantages and disadvantages of static tests.

\subsection{ACCELERATED DISSOLUTION (ELECTROCHEMICAL OISSOLUTION)}

Accelerated test methods are generaliy used for investigating mechanisms of dissolution rather than rates of dissolution or solubility limits of various waste form constituents (e.g., Wang 1981a; Sunder et al. 1982). These methods are frequently used in conjunction with sophisticated surface analysis techniques (e.g., scanning electron microscopy, $x$-ray photoelectron spectroscopy), which provide information on the composition, thickness, and uniformity of films that form on the waste form surface under various conditions. 
Accelerated test methods involve an electrochemical cell in which a piece of $\mathrm{UO}_{2}$ or spent fuel is used as one of the electrodes. An outside source of electric power is generally used to step or ramp the potential of this electrode (which is measured against a standard electrode such as the saturated calomel electrode). This induces accelerated oxidation and/or dissolution of the electrode surface. The current observed as a function of time or potential is a direct indication of 1) the oxidation or reduction of a layer on the surface of the electrode, or 2) the dissolution of species from the surface of the electrode. An anodic step or scan (increasing potential) will cause oxidation and consequent dissolution of the electrode surface, while a cathodic step or scan (decreasing potential) will cause reduction of oxidized species on the surface. By abruptly removing the applied potential at various points in time or at various potentials and removing the electrodes from the cell to examine their surfaces, the investigator can determine which oxidized species are formed at the surface and in what order they are formed.

During a scan, sluggish increases in current with increasing potential generally indicate the presence or growth of an oxidized surface layer which serves to passivate the surface, while rapid increases in current with increasing potential indicate that dissolution is occurring. After an anodic step or scan, a reverse cathodic sweep can provide additional information on the thickness and nature of oxidized layers that formed on the surface of the electrode. These reverse scans also allow the experimentalist to determine the fraction of anodic current that went towards oxidation of the electrode surface and the fraction that went towards dissolution (since cathodic scans cause only the reduction of oxidized layers on the electrode surface and not the precipitation of dissolved species).

Electrochemical dissolution experiments have been carried out in a number of different solutions at various temperatures and $\mathrm{pH}^{\prime} \mathrm{s}$. Mechanisms of oxidation and dissolution of $\mathrm{UO}_{2}$ derived from electrochemical experiments have been proposed by Nicol and Needes (1975, 1977), and by a team of Canadian investigators (Sunder et al. 1981, 1982, 1983; Shoesmith et a1. 1983, 1984). Wang and Katayama used electrochemical methods to propose mechanisms for dissolution of 
both $\mathrm{UO}_{2}$ and spent fuel, but they did not propose mechanisms for oxidation (Wang and Katayama 1980; Wang 1981; Wang and Katayama 1981a, b, and c, 1982). Their results indicated, however, that dissolution of uranium occurred primarily after oxidation of the surface of the $\mathrm{yO}_{2}$ or spent fuel. A more detailed discussion of the mechanisms of oxidation and dissolution is given in Section 6.8 . 


\subsection{REPORTING OF RESULTS}

Results from radionuclide release tests have been reported in numerous ways in the literature. An excellent review of these is given by McVay, Bradley and Kircher (1981). The most common methods are summarized below:

Release Rates

- Normalized release rate, $g / m^{2}$-day

- Release rate, g/day

- Activity release rate, Bq/day or Ci/day

- Fractional release rate, fraction/day $\left(\right.$ day $\left.^{-1}\right)$

- Penetration rate, m/day

Integrated Release

- Normalized release, $g / \mathrm{m}^{2}$

- Fractional release, fraction (no units)

- Weight loss, g

- Concentration, $\mathrm{g} / \mathrm{mL}$

Each of these methods of reporting release can be based on different elements in the waste form. Usually the fractional release with respect to a given element is determined by measuring the activity level of that element in the solution and dividing this by the total activity of that element in the waste form specimen. The latter quantity is generally calculated from a computer program for radionuclide generation and depletion such as the ORIGEN-2 code developed at Oak Ridge National Laboratory (Croff 1980). (a) The fractional release can be used to calculate the release or release rate by any of the units given above provided the following parameters are known:

(a) ORIGEN-2 calculations for inventory determinations in small test samples may be subject to large errors. The calculations are frequently relied on for relative inventory determinations while the absolute amounts are determined by "calibrating" the calculations with the measurement of an easily qeasurable fission product that is soluble in the $\mathrm{UO}_{2}$ matrix (e.g., $\left.{ }^{44} \mathrm{Ce}\right)$. 
- weight of the waste form specimen, $g$

- surface area of the waste form specimen, $\mathrm{m}^{2}$

- density of the waste form specimen, $\mathrm{g} / \mathrm{m}^{3}$

- volume of the solution sample, $\mathrm{mL}$

- number of days solution has been in contact with waste form, days.

In this report (Chapter 6.0), all results from dynamic tests have been presented as fractional release rates, and all results from static tests have been presented as fractional release or concentration. Whenever release or release rates were reported in the literature by other methods, the units of the reported values were converted accordingly. These conversions were done primarity to offer consistency in presentation of the data.

It must be acknowledged that fractional release rates are expected to be directly proportional to the surface area of spent fuel samples. For this reason, release rate data are often reported as normalized release rates $\left(g / m^{2}-d a y\right)$. This method of presentation removes the surface area dependence from the reported values and provides a comon basis for comparison of the data. The data in this report are not presented on a normalized basis for two reasons: 1) surface areas are often not reported in the literature, and 2) there is a great deal of uncertainty associated with the measurement of surface area. Most of the comparisons of data in this report are based on results from tests in which the spent fuel samples were obtained from the same source and prepared in the same way. Therefore, it is assumed that the surface areas of the samples are approximately the same, and any observed differences in the release behavior between samples are caused by factors other than surface area. In cases in which there is a reason to expect a difference in surface area between samples, it is pointed out that some of the observed difference in release behavior may be caused by a difference in surface area. 


\subsection{STUDIES OF RADIONUCLIDE RELEASE FROM URANIUM DIOXIDE AND SPENT FUEL}

Most studies of radionuclide release from uranium dioxide $\left(\mathrm{UO}_{2}\right)$ and spent fuel that are relevant to disposal in a geologic repository have been done within the past 10 years. Before that, virtually no studies were conducted on spent fuel. Those that were conducted on $\mathrm{UO}_{2}$ were frequently directed at intentional dissolution processes such as leach mining (Pearson and Wadsworth 1958; Parkhaeva and Gromov 1975; Hiskey 1979, 1980), or at the collection of basic thermodynamic data Gayer and Leider 1957; Tremaine et al. 1981; Ryan and Rai 1983). This section presents all the repository-relevant studies of radionuclide release from $\mathrm{UO}_{2}$ and spent fuel that have been found in the literature. Part of this section is devoted to studies on simulated spent fuel, which is essentially $\mathrm{UO}_{2}$ fabricated to contain quantities of fission product compounds that are typically found in spent fuel.

It should be noted that there are three major differences between unirradiated $\mathrm{UO}_{2}$ and spent fuel that can affect radionuclide release behavior. (The effects that each of these characteristics have on release will be discussed in later sections.) First, spent fuel typically has an intense radiation field associated with it while $\mathrm{UO}_{2}$ has essentially no radiation field. Second, spent fuel pellets are generally fractured due to thermal cycling and large radial and axial temperature gradients that develop during irradiation. In contrast, $\mathrm{UO}_{2}$ pellets are almost always structurally intact. This difference is important when intact waste forms are studied. Third, spent fuel frequently contains a number of secondary phases and inclusions consisting of fission product compounds, actinide compounds, and fission gases that are not incorporated in the original fuel matrix whereas $\mathrm{UO}_{2}$ is generally a homogeneous material.

\subsection{URANIUM DIOXIDE}

Studies of uranium release from unirradiated $\mathrm{UO}_{2}$ provide useful insights into the behavior of spent fuel under geologic disposal conditions because spent fuel is generally over $95 \% \mathrm{UO}_{2}$ and therefore its chemistry can be expected to be dominated by $\mathrm{UO}_{2}$. Also, $\mathrm{uO}_{2}$ studies are much less expensive to conduct than spent fuel studies because they do not require the extensive 
radioactive shielding that spent fuel studies require. Experiments have been conducted under a variety of conditions using both natural and enriched $\mathrm{vO}_{2}$ pellets and crushed $\mathrm{UO}_{2}$.

The literature contains several references to studies that provide useful insights into the dissolution kinetics and solubility of uranium species under various conditions, but in many cases these conditions are not relevant to geologic disposal. Many studies have pointed out the importance of acids and carbonate species in enhancing the rate of dissolution of $\mathrm{NO}_{2}$ (Pearson and Wadsworth 1958; Schortmann and DeSesa 1958; Parkhaeva and Gromov 1975; Grandstaff 1976; Hiskey 1979, 198D; Gromov 1981). However, these studies were generally carried out at higher concentrations of acids and carbonates than are expected in deep geologic ground waters. Also, in many studies the uranium sample being dissolved contained significant quantities of uranium in higher oxidation states than $\mathrm{UO}_{2}$, as is typical in natural uranium ores (Gayer and Leider 1955; Grandstaff 1976; Rich, Holland and Peterson 1977; Scott, Glasser and Nicol 1977; Holland and Brush 1978). The higher oxides of uranium have been observed to dissolve faster than $\mathrm{UO}_{2}$ under most conditions.

Many of the solubility studies of uranium have been conducted under much more alkaline conditions than are considered to be possible in a geologic repository (Gayer and Leider 1957; Tremaine et aT. 1981; Ryan and Rai 1983). The purpose of these studies has been to obtain basic thermodynamic data on species and reactions that are predominant under alkaline conditions (pH>12). In this section, only studies of uranium release from $\mathrm{UO}_{2}$ under conditions that are considered to be possible in a geologic repository are presented.

Table 1 summarizes some of the $\mathrm{UO}_{2}$ studies relevant to geologic disposal that have appeared in the literature. Included among these are two studies of uranium solubility in ground waters and sodium chloride (NaCl) solutions (Dosch 1981; Silva and Yee 1981). The source of uranium in these experiments was the uranyl ion $\left(\mathrm{UO}_{2}^{+2}\right)$, which is expected to be the primary species dissolving from $\mathrm{UO}_{2}$ under disposal conditions. The results from these studies are discussed " $n$ Section 6.0 . 


\section{TABLE 1. Studies of Uranium Release from $\mathrm{UO}_{2}$}

\begin{tabular}{|c|c|c|}
\hline -_-_Labaratory & $\begin{array}{l}\text { Oescription of } \\
\text { Solid Specimen(s) }\end{array}$ & Description of Solution (s) \\
\hline $\begin{array}{l}\text { Pacific Northwest } \\
\text { Laboratory (PNL). USA }\end{array}$ & $\begin{array}{l}\text { Samples: Single crystal } \\
\quad \text { U0 } 2 \\
\text { Mass: } 3-69 \\
\text { Surface Area: }-4 \mathrm{~cm}^{2}\end{array}$ & 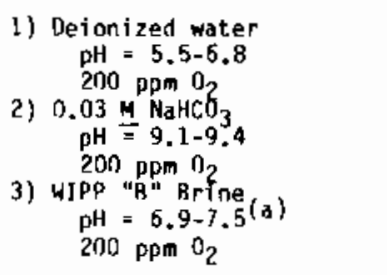 \\
\hline $\begin{array}{l}\text { Los Alamos National } \\
\text { Lahoratory, USA }\end{array}$ & $\begin{array}{l}\text { Samples: Finely divided } \\
\quad 1,02 \\
\text { Mass: } 8-100 \mathrm{mg} \\
\text { Surface Area: } \\
-1.30 \mathrm{~cm}^{2} / \mathrm{mg} \\
(\text { calculated) }\end{array}$ & $\begin{array}{l}\text { 1) Deionized water } \\
\mathrm{pH}=4.2 \pm 0.2 \\
\mathrm{Eh}=-0.15 \pm 0.03 \mathrm{~V} \\
\mathrm{H}_{2} \text { bubbled through } \\
\text { 2) Deionized water } \\
\mathrm{\rho H}=4.1 \pm 0.2 \\
\mathrm{En}=+0.48 \pm 0.04 \mathrm{~V} \\
20 \pm \mathrm{O}_{2} \text { in } \mathrm{N}_{2} \text { hubhled } \\
\text { through } \\
\text { 3) Beionized water } \\
\mathrm{pH}=3.5 \pm 0.2 \\
\mathrm{Eh}=-0.18 \pm 0.3 \mathrm{~V} \\
\mathrm{H}_{2} \text { bubnied through }\end{array}$ \\
\hline
\end{tabular}
Experimental Procedure and Conditions
Purpose: Determine solubility and dissolution rate in 3 different
solutions at different temperatures
Method: Static test
Container Material: Hastelloy C (Auto- clave) ( $1 \mathrm{JO}_{2}$ contained in $\mathrm{Ti}$ capsules)

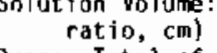

Runs: Tatal of six; once with each solution at two different temps

Temps: $78^{\circ} \mathrm{C}$

Duration: 81 days

Plateout: Yes
Purpose: Determine solubility under oxidizing and reducing conditions axidizing and reducing cond Method: Static test with $\mathrm{H}_{2}$ or $20 \% \mathrm{O}_{2}$ in
Container Material: Polyethylene (sealed from atmosphere)
Solution Volume: 2.0-2.1 biters
Runs: Total of 4
1. Solution 1 at high temp for 55 days
2. Solution 2 at high temp for 55 days
3. Solution 2 at high temp then low temp for last 5 days of 12-day run
4. Solution 3 at low temp for 200 days with conditions altered after 84 days Temps: $25^{\circ} \mathrm{C}$

Platenot: No mention
References

1981

Wang and Katayama 1981b Wang and Katayama 1981 Whe and Katayama 1982
Norris $19 / 8$

Norrts $1979 \mathrm{~b}$

Norris 1979

Norris 1979 d

Norris 1980a

Norris 1980 b

Norris $1980 \mathrm{c}$

Ogard and Duffy 198

(a) $\mathrm{pH}$ values for hrine solutions are inexact because it is difficult to accurately measure pH in high ionic strength solutions. ? = Not reported. 
TABLE 1. (contd)

\begin{tabular}{|c|c|c|c|}
\hline Lahoratory. & $\begin{array}{l}\text { Description of } \\
\text { Solit Specimen(s) }\end{array}$ & & escription of Salution (s \\
\hline $\begin{array}{l}\text { Technical Research } \\
\text { Center. Finland }\end{array}$ & $\begin{array}{l}\text { Somples: } \mathrm{UO}_{2} \text { pellets } \\
\text { Mass: } 13-14{ }^{9} \\
\text { Surface Area: } 7.9 \mathrm{~cm}^{2}\end{array}$ & 2) & $\begin{array}{l}\text { Deionized water } \\
\mathrm{pH}=? \\
\text { Eh }=\text { ? } \\
\text { Saturated with air } \\
\text { Olkiluoto groundwater } \\
\mathrm{pH}=8.2 \text { initially } \\
\text { deaerated prior to use } \\
\text { Stripa groundwater } \\
\text { pH }=8.3 \text { initially } \\
\text { deaerated prior to use }\end{array}$ \\
\hline
\end{tabular}

1) Olkiluato groundwater $\mathrm{ph}=8.2$ initially $E h=-0.40$ to -0.20 2) Stripa groundwater $\mathrm{pH}=8.3$ initially
$\mathrm{Eh}=-0.3$ to $0.0 \mathrm{~V}$

3) nlkiluoto grnuniwater $\mathrm{\rho H}^{\mathrm{H}}=8.2$ initially

"oxidizing conditions"

4) Stripa groundwater $\mathrm{pH}=8.3$ initially
"oxidizing conditions"
Experimental Procedure and Conditions

Purpose: Determine rate of dissolution in 3 different solutians at different temperatures

Method: Madfifed JaEa test

Container Material: Polyethylene

Solution Volume: $77 \mathrm{~mL}$

Runs: Total of 10

2 with solution 1 at low temp

2 with solution 2 at low temp

2 with solution 2 at high temp

2 with solution 3 at low temp

2 with solution 3 at high temp

Temps: $\begin{aligned} & 25^{\circ} \mathrm{C} \\ & 50^{\circ} \mathrm{C}\end{aligned}$

Duration $=612$ to 732 days

Plateout: No ment ion

Purpose: Determine solubility and rate of approach to solubility under oxidizing and reducing conditions in different solutions

Hethod: Static test for oxidizing condi$t$ ions. modified IAEA for reducing conditions

Container Material: Polyethylene

Solutian Volibme: $77 \mathrm{~mL}$ for redisciny $38 \mathrm{~mL}$ for oxidizing

Runs: Several at low temp under reducing conditions for hoth groundwaters

3 each at high temp under oxidizing

conditions for both groundwaters (6.

Temps: $25^{\circ} \mathrm{C}$

Duration: 6, 12, and 22 imonths Plateout: No mention, but precipitates
References

011 ila 1985

\section{Ollila 1965}

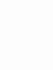




\section{TABLE 1. (contd)}

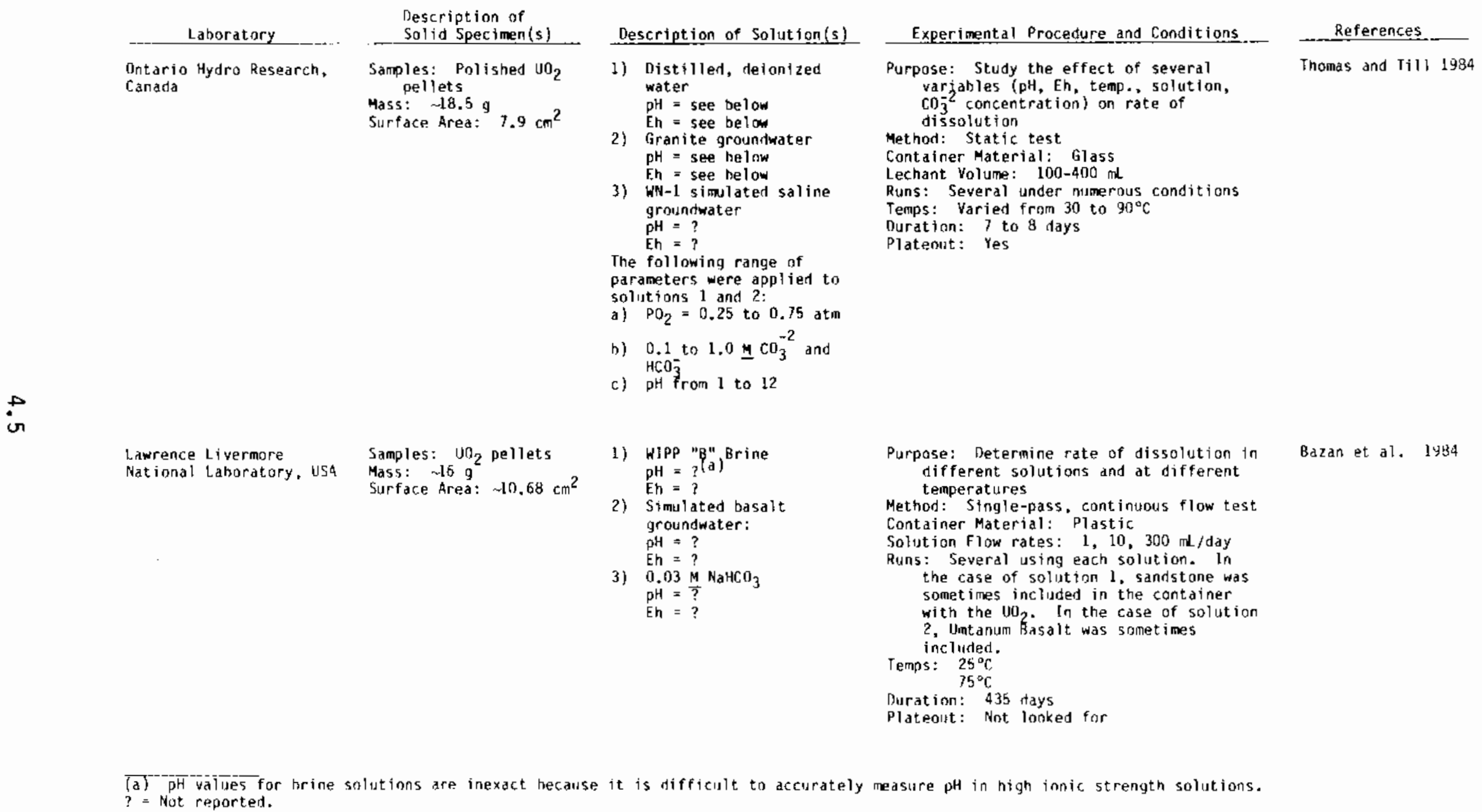




\section{TABLE 1. (contd)}

\begin{tabular}{|c|c|}
\hline Laboratory & $\begin{array}{l}\text { Uescription of } \\
\text { Solid Specimen(s) }\end{array}$ \\
\hline $\begin{array}{l}\text { Pacific Nortnwest } \\
\text { Laboratory (PNL), USA }\end{array}$ & $\begin{array}{l}\text { Samples: } \quad \mathrm{UO}_{2} \text { pellets } \\
\text { Mass:? } \\
\text { Silfface Area: } \begin{array}{l}3.60 \mathrm{~cm}^{2} \\
\end{array}\end{array}$ \\
\hline
\end{tabular}

Sandi National Laboratory, USA
Sample: dissolved J(VI) nitrate salt adder

to solutions

\section{Description of Solution(s)}

1) Synthetic Permian Basin Brine 0 inal $=4.4$ to

Deionized water Final $\mathrm{pH}=3.9$ to 8.1 air atmosphere

\section{Experimental Procedure and Conditions}

Purpose: Study the effects of the presence of various constituents on dissolution in various solutions at different temperatures

Methor: Static test (MCC-1)

Container Material: Teflon lined

Solution Volume: 36 In (10:1 Volume/

SA ratio, cm)

Runs: Several with each solution at different temps and for different durations

Systems studied-

1. $\mathrm{U}_{2}$-solution

2. $\mathrm{UO}_{2}$-i ron-solution

3. $v 0_{2}^{2}$-zirconium-solution

Telnp : :

4. $10_{2}^{2}$-iron-zirconium-solution

$75^{\circ} \mathrm{C}$
$150^{\circ} \mathrm{C}$

Duration: $2,5,7,14,26$, and 60 days

Plateout: Do Iron

Purpose: Determine solubility and sorption

of urantum in different solutions

Simulant representing with potash materials

with potash materials

2) $\mathrm{PH}=7$, WIPP prine in contact with halites $\mathrm{pH}=7, \mathrm{~g}, 9$

3) $\mathrm{simul}$ Simulant representing "typical" potable wipo pH $=7,8,9$ (adjusted)

Method: Static test

Container Material: Polyethylene

Solution Volune: $10-15 \mathrm{~mL}$

Runs: 1 for each solution at each ph.

Starting values of $U\left(V_{I}\right)$ concentration

were 1,10 , and $50 \mathrm{mg} / \mathrm{L}$

Temp: Room temp

ation: 5 days

Plateout: No mention
References

Gray and Mclay 1 yis 4 Gray and McVay 1986

(a) pH values for brine solutions are inexact because it is difflcult to accurately measure pH in high ionic strength solutions. $?=$ Hot reported. 


\section{TABLE 1. (contd)}

Laboratory

Lawrence Berkeley

Laboratory, USA

$+$

South Africa

$?=$ Not reported. - solid specimen(s)

Sample: dissolved U(VI) salt added to solutions

1) $0.001 \mathrm{M} \mathrm{NaCl}$ $\mathrm{pH}=5$ to 10

2) $0.1 \mathrm{M}$

$$
0.1=-\frac{M}{0 H C l} 10
$$

$\mathrm{Eh}=$ ?
Samples: (electrodes): 1) Sintered Uil $_{2}$ pellet.

3) Single crustal 110 3) Fused polycrystal-
line $\mathrm{JO}_{2}$ with $\mathrm{U}_{4} \mathrm{O}_{9}$ Mass: ?
1) 0.1 to $1.1 \mathrm{MAClO}$ $\mathrm{\rho H}=$ varied from 2 to 13

2) $0.1 \mathrm{M}$ to $1.0 \mathrm{M} \mathrm{NaClO}_{4}$

3) ${ }^{\mathrm{PH}}=$ ? $\mathrm{MaClO}$ alus $10^{-3}$ to

$10^{-1} \mathrm{M} \mathrm{Na} \mathrm{NaO}_{3}$
$\mathrm{H}=\frac{9}{9} .8$

4) $0.5 \mathrm{M}$ and $1.0 \mathrm{M} \mathrm{Na}_{2} \mathrm{CU}_{3}$ $\mathrm{pH}=9$ to 11
Experimental Procedure and Conditions

Purpose: Determine solubility and sorption of uranium in different solutions at various $\mathrm{pH}$

Method: Static test

Container Material:

Container Material: No mention

Solution Nolume ment ion

Rans: 2 at each ph with initial concen-$$
\text { tration }
$$

Temp: $23{ }^{\circ} \mathrm{C}$ ( 5 and 10 weeks

Puration: 8.5 and 10

Purpose: Sturdy mechanisms of 100 dissalution in carbonate and perchlorate solutions

Method: Electrochemical

Container Material: Titaniu

Solution Volume: ?

Runs: Several with each sample and each solution

Jemp: $25^{\circ} \mathrm{C}$
References

Silyd and ree lyal

Nicol and Needes 1475 Nical and Reedes $19 / 1$ 
TABLE 1. (contd)

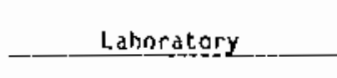

Whiteshell Nuclear

Research Establishment.

Canada

Pacific Northwest Laboratory (PNL), USA
Description of

Solid Specimen(s)
Samples: (electrodes):
Polycrystalline U0,
from unused CANDU
fuel bundle

fuel bundle

Description of Solution(s)

1) $0.5 \mathrm{~mol} / \mathrm{sm}^{3} \mathrm{Ma}_{2} \mathrm{SO}_{4}$

2) $0.5 \mathrm{~mol} / \mathrm{dm}$ Na2 $\mathrm{SO}_{4} \mathrm{pl}$ us

0 to $0.5 \mathrm{~mol} / \mathrm{dm}^{3} \mathrm{CO}_{3}$ $\mathrm{pH}=$ ?

3) $\mathrm{O}_{2}$ a mol mosphere $/ \mathrm{dm}^{3} \mathrm{CO}_{3}=$ $\mathrm{pH}=9.5$

$\mathrm{N}_{2}$ atmosphere

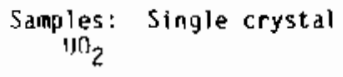

1) Deionized water

2) $0.03=5.3-5.7$

$\mathrm{pH}=\overline{9} .0-9.3^{3}$

3) air atmosphere

WIPP "B" brine,
$\mathrm{pH}=7.0-7.3(\mathrm{a})$

air atmosphere

\section{Experimental Procedure and Conditions}

Purpose: Study mechanisms of axidation and dissolution of $\mathrm{NO}_{2}$

Method: Electrocheni?

Solution Volume:?

Runs: Several in each solutio

Temps: $25^{\circ}$ to $30^{\circ} \mathrm{C}$

Purpose: Study mechanisms of dissolution Method:

Method: Electrochemical

Container Material: Pyrex glass

Runs: At least one $250 \mathrm{~mL}$

at tuo different in each solution

Temps: $25^{\circ} \mathrm{C}$
References

Sunder et al. 1981 Sunder et al. 1982 Shoesmith et al. 1983 Shoesmith et al. 1983
Wang 1981

Wang and Katayama 198la Wang and Katayam 1981 Wang and Katayama $1981 c$ Wang and Katayama 1982 \{a! pH values for brine solutions are inexact becalise it is rifficult to accurately medsure pH in high ionic strength solutions.
$?=$ Not reportes. 


\subsection{SPENT FUEL}

Several studies of radionuclide release from spent fuel relevant to geologic disposal have been conducted within the last 10 years. These have been carried out under a variety of conditions and for numerous purposes. Most

studies have been conducted on 1 ight-water reactor fuels enriched in ${ }^{235} \mathrm{U}$, but the Canadians have done several studies on natural uranium fuel irradiated in deuterium water reactors. The fuels that have been studied have had several different irradiation histories. Fuel specimens have included pellets with cladding, pellets without cladding, and crushed spent fuel; solutions have included deionized water and all types of ground waters. In some experiments, host rock and/or waste package barrier materials have been included in the testing systems. Table 2 summarizes the spent fuel radionuclide release studies that have appeared in the literature. The results from these studies are discussed in Chapter 6.0.

\subsection{SIMULATED SPENT FUEL}

Studies of release from simulated spent fuel (SSF) have been conducted by Rockwell Hanford Operation's Basalt Waste Isolation Project (Apted and Myers 1982; Grandstaff et al. 1983; Myers, Apted and Mazer 1984; McKeon et al. 1984). The simulated spent fuel contains the same stoichiometric quantities of fission product compounds (albeit non-radioactive isotopes) as 1D-year-old pressurized water reactor (PWR) fuel with a burnup of $33 \mathrm{MWd} / \mathrm{kg} \mathrm{U}$. It is fabricated at the Hanford Engineering Development Laboratory (operated by Westinghouse Hanford Company). The SSF provides a waste form of the same bulk composition as spent fuel without the radiation field associated with spent fuel. Details of the composition and the fabrication procedure are given by Woodley, Wilson and Hervig (1981).

Although the simulated spent fuel has the same bulk composition as spent fuel, investigators should be careful when comparing SSF release test results to spent fuel release test results for two reasons: 1) unlike the spent fuel, SSF does not have a radiation field associated with it and 2 ) the various components of SSF are probably not distributed in the grains and along the grain boundaries in the same way that they are in spent fuel. Simulated spent fuel 
TABLE 2. Studies of Radionuclide Release from Spent Fuel

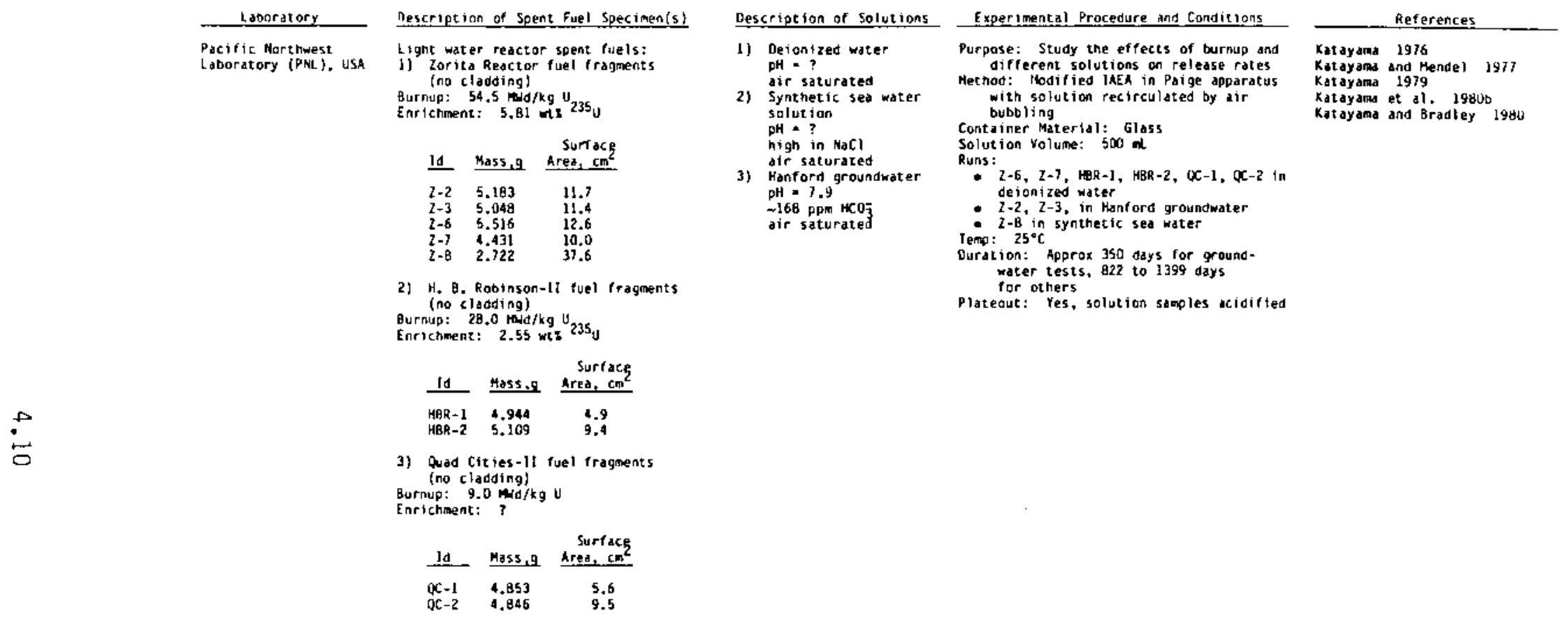

P. Not reported. 
TABLE 2. (contd)

\begin{tabular}{|c|c|}
\hline Labaratory. & Bescription of Spent Fuel Specinen $(s)$ \\
\hline 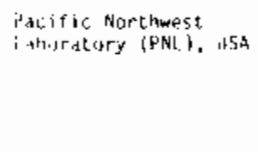 & 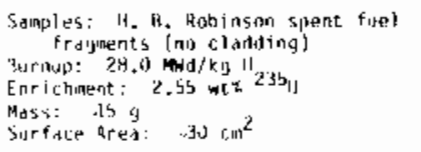 \\
\hline 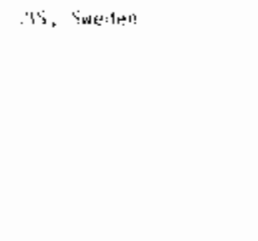 & 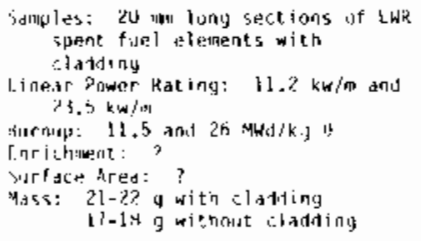 \\
\hline
\end{tabular}

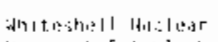

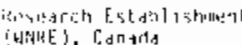
Sintwles: fic cin lung sections ot Burmat: 7.1 madikg is Enrichunent: natural 1.i near Power Ratinal; $53 \mathrm{~km} / \mathrm{n}$ Surface trea: $3.2 \mathrm{~cm}^{2}$ (pands of

flescription of Solution(s)

1) Dernnized water 4.3 at end of run

2) $0.03 \mathrm{M}$. $\mathrm{FaCl}^{\circ}$

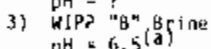

4) $0.03 \mathrm{~m} \mathrm{NaHCU}_{3}$

b) $\begin{aligned} & 2 \mathrm{H}=? \\ & \mathrm{H} H \mathrm{Ul}\end{aligned}$

1) Distilled water

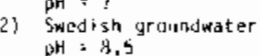
$300 \mathrm{Ppm} \mathrm{HCU} 3$

1) Distilled, deionized water air saturated ) Chlorinated river phot $=7.7$ air saturated
E.xperimental Procmilure and Cond!tions Purpose: Study the eftects of alfferent solutions on release rates Methort: Modified laEA
Container Material: High densit. Container Material: High density
polypropyleme (sealed)

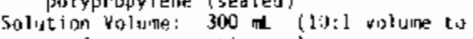
surface dred ratio, cons
Runs: 1 in each solution

Temp: $25^{\circ} \mathrm{C}$

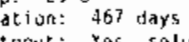

Plat eout: Yes, solution samples acioluted

Purpose: Study the effects of $1 \mathrm{inted}$ power rating and different solutions on release rates Container Material: Gilas Solution Volune: 5.30 id
Runs: 4 total: 1 in each sinlution for each fuel power rating Temp: $611^{\circ} \mathrm{C}$ C

Duration: $113 \mathrm{~s}$ iays
Platenit:

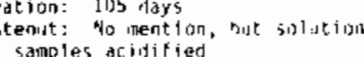

Purpose: Study the effect of tifferent Methorl: Modified LAE: a rates

Container Material: Oolyethylens

solut ion vilutite:

Runs: 4 total: 2 in each solution

Ouration: yuu days

Platenut: Ho mention, fut solut fur samples dcidifles -o_retereitices. ........ Katayans et al. 14tida

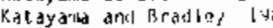

Eklund arist fursyth $\mid y / y$ $19 \mathrm{H}_{3}$

Vanderyrat itis

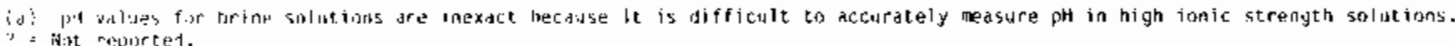




\section{TABLE 2. (contd)}

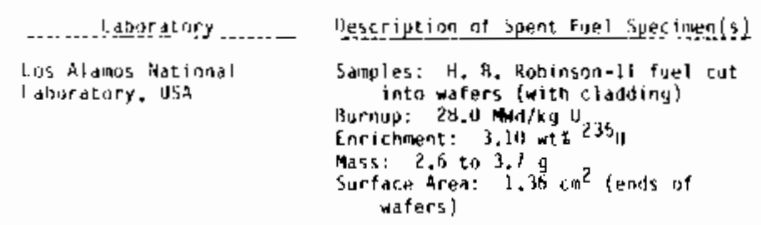

$\stackrel{+}{*}$

Pak Lisye Wat inol
Descrigtion of solutiontsl.

1) Deianized water

$\begin{aligned} \mathrm{pH} & =4-5.5 \\ \mathrm{En} & =+0.49 \mathrm{y}\end{aligned}$

2020 , bubbled through

$\mathrm{pH}=4-5,5$

$\varepsilon h=-0.12 \mathrm{~V}$

in $\mathrm{H}_{2}$ buhssiet throwyh

amples: Crushed ikermet:-1 spant

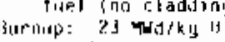

Mass: 104

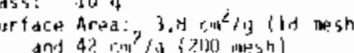

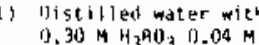
$0.04 \mathrm{M}$ $\mathrm{pH}=\mathrm{B} . \mathrm{O}$

(reactior pool conling
Experinent th Procesture dnat rondicions. urpose: Study the effects of temperature Method: Modified IAEA

Container Materidi; blas

Runs: atotal: 2 in each solut

temp raised froin $25^{\circ} \mathrm{C}$ to $70^{\circ} \mathrm{C}$ after 65 days
remp: $25^{\circ} \mathrm{C}$

$70^{\circ} \mathrm{C}$

Diration: 19u Fdys

Ourpuse: Deterining ruleaser rutus in

react or conling water

Container Material: fildass

Shlution yolune:

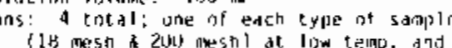
Iennps: $85^{\circ} \mathrm{C}$

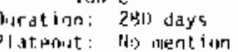

…ㄹeterences

Norris ly7s

Morris $1979 \mathrm{~d}$

Morris $1979 \mathrm{~b}$

Norris $1979 \mathrm{C}$

Norris lybilda

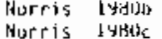

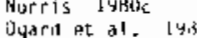

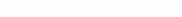

Mitchell, Gnats: 


\section{TABLE 2. (contd)}

\begin{tabular}{|c|c|}
\hline Esporatory & Description of Spent Fuel speciment \\
\hline WNRE, Canada & 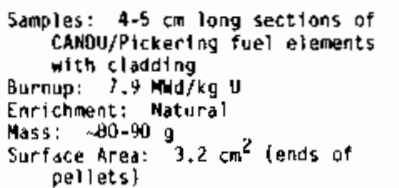 \\
\hline
\end{tabular}

Description of Saluttan(s)

1) Distilled, delonized pht $=5-5.6$

a) Dist saturated pressures ranging from
20 to $700 \mathrm{kPa}$

3) Granite groundwater $\mathrm{pH}$ - 5.9 to 7.5
air saturated

4) Giranitue groundwater $\mathrm{ph}=\sim 7$
at $100 \mathrm{kPa} \mathrm{H}_{2}$ pressure
- Experimental Procedure. dnd Conditions Purpose: Study the effects of $\mathrm{O}_{2}$ pres. solut tons on release rates and tot a Method: Madifled JAEA followed by static tests of varying duration

- polyethylene for madifted laEa tests - statnless steel autociaves for one day Static tests
- titaniuar autoclaves for longer static

- tiraniuir aut

Solution Volumes: $100 \pi$ for modified IAEA and one day static tests
$500 \mathrm{~mL}$ for longer static tests

Runs: 1 il samples leached by IAEA metriod in All samples leached by IAEA method
solut 1 an 1 for $100-120$ days at $25^{\circ} \mathrm{C}$. prior to static testing 5 one day static tests in solution 2
at $20,200,300,400$, and $700 \mathrm{kPa} 0_{2}$ pressure
2 static tests in solution $\mathrm{l}$ at $150^{\circ} \mathrm{C}$ for 10 days
3 static tesis in solution 3 at $150^{\circ} \mathrm{C}$ 3 static tescs in solution 3 at $150^{\circ} \mathrm{C}$
for 8 to 28 days 5) for 8 to to test in solution 4 at $150^{\circ} \mathrm{C}$ for $\sim 20$
Temps : $23^{\circ} \mathrm{C}$

$150^{\circ} \mathrm{C}$

Buration: see NRuns" above samples acidified
Johnson et al. 1961 Johnsan et al. 1961
Johnson and Joling 1962 


\section{TABLE 2. (contd)}

\begin{tabular}{|c|c|}
\hline ….. !abogotat ury & Desctription of Spent Fuet Specinenis \\
\hline MlHEE, Canada & 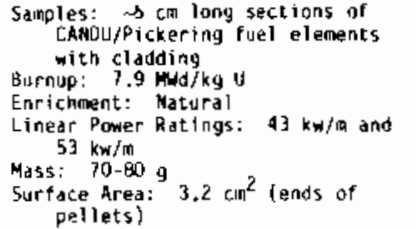 \\
\hline
\end{tabular}

KBS, sweden
Description of Solutionts

1) Distilled, deionized phe $=5.0$

2) 5 medish groundwate

3) Granite groundwater $\mathrm{pH}=6.5-7.0$ at $0_{2}$ from $1 \times 10^{-6}$ to $2.5 \times 10$

4) Standard Candatian snfeld saline solution Samales: $20 \mathrm{~mm}$ long sections of LWR
spent fuel elements with cl adding 42 MHd $/ \mathrm{kg} 11$ Enritchment: ? Mass: $20 \mathrm{~g}$ with cladding Surface trea: ?

1) Deionized water

oxldizing conditions

2) Smedish groundwater

$\mathrm{PH}=8.0-8.2$

-123 $\mathrm{ppm} \mathrm{HCO}_{3}^{-}$

3) Same ds (2), but
Experimental Prucedure and Condt tions

Purpose: Study the effects of $\mathrm{O}_{2}$ concentration, hinear powter rating. rates

Contatner Materials: Polypropylene tod glass (for $U_{2}$ bubbling experinents) Solutian Valume: 100

Runs:

- 2 with each solution

- 1 at each of the $0_{2}$ concentrations in

- I of fuel with each power rating in

emp: $25^{\circ} \mathrm{t}$

Turation: -900 days for each solution

Plateout: Yes solution samples acidified

Purpose: Study the effects of different solutions and different oxidizing/ reducing conditions an release rates

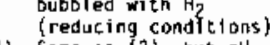

4) Same os (2), but pH
adjusted to 2 to 5

Method: Modifted IKEA and Static Contatmer Matertal: Pyrex glass Solution Vol une: 290 it.

Runs:

Series of motified IAEA tests in

2) Sertes of

solution?

Series of static tests in solution

for to by at

f) for 20 days at end of test solution 2 followed by static test in solut ion 3

Ouration: 360 to 570 days
Plateout: No mention, Dut solution samples acidified
-_- References

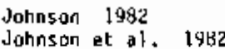

Farsyth 196:2

Forsyth et al. 1984 


\section{TABLE 2. (contd)}

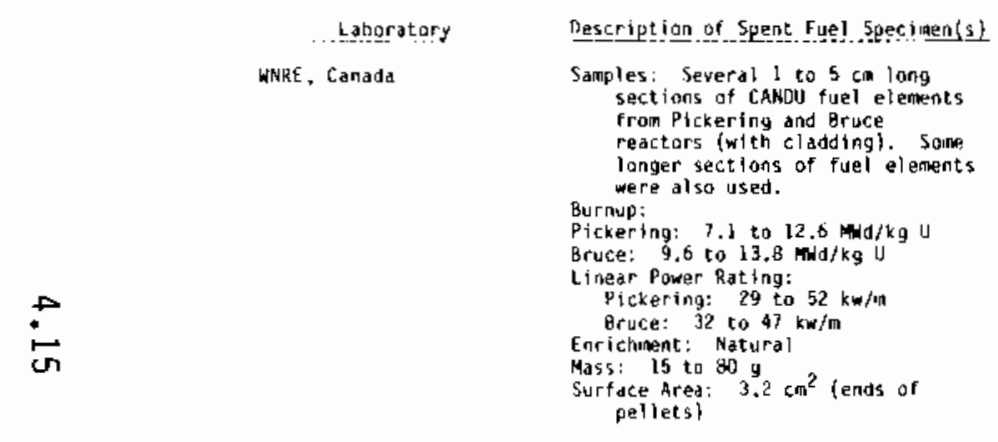

Descriptign of Solution(s)

1) Distilled. deionized $\mathrm{pH}=$ ?

$\mathrm{pH}=$ saturated
air saturi
$0.2 \mathrm{~g} / \mathrm{kI}$

$0.2 \mathrm{~g} / \mathrm{L} \mathrm{KI}$
air 5 sturated

$9 / \mathrm{CSCl}$

4) $1.0 \mathrm{~g} / \mathrm{L} \mathrm{I}^{-0.01} \mathrm{~g} / \mathrm{L} \mathrm{C}_{5}+$

5) 0.5 gaturated $\mathrm{NaCl}$
Experimental Procedure and Condittons-_ Purpose: Study the rapid release of $C_{S}$ Methods: Modifled IAER, continuous flow. and static Container Material: Plastic at low temp.
titantum or stainless steel at high terp. Solution. Volumes: Modified IA

Continuous Flow:
Static: 1 to 7 L

1) Several modified IAEA tests at $25^{\circ} \mathrm{C}$ in solutions 1,2 and 3 for anywhere from 30 to 300 days
Some tests involvis

Some tests involving cont t nuous flow flow bet ng through a long $\mathrm{C}$ with the fuel element

3) Several stat $1 c$ tests with salution

4) Two static tests at $150^{\circ} \mathrm{C}$ on whole Two static tests at $150^{\circ} \mathrm{C}$ on whole
fuel elements with 1 to 5 m slit cladding defects in claddins Temps: $25^{\circ} \mathrm{C}$

Duratian: Few days to 300 days
References Burns. Moore and Johnson et al. 1983
Johnson et al. 1984 
TABLE 2. (contd)

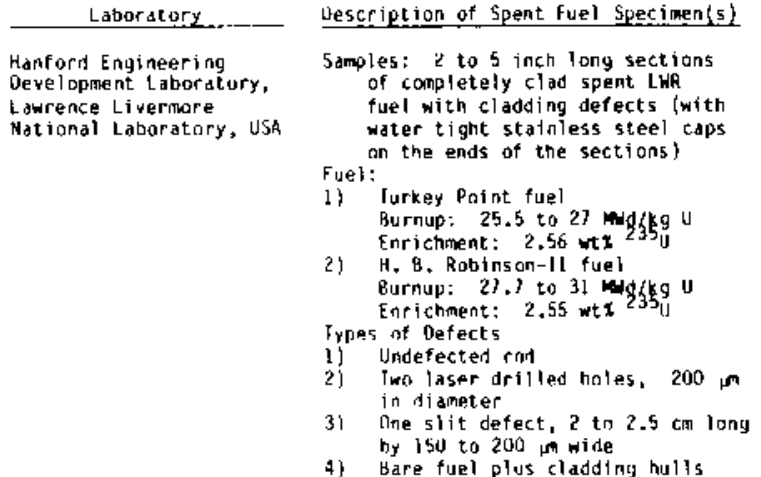

in
Description of Solution(s) Experimental Pracedure and Conditions.

1) Deionized water

2) $\mathrm{pH}=6$ to 7 Yutca Mountain, Nevada
$\mathrm{pH}=7.2$ to 8.5 during ${ }_{\rightarrow 120}^{\text {test }} \mathrm{ppm}_{\mathrm{HCO}}^{-}$ Purpose: Study the containinent of
radionuclides proytded by spent fue athod: Essentially static with some replenishment (semi-static) Cantalner Material: Fused quartz
Solution volume: 250 iL $10 \mathrm{~m}$ samples Solution Volume:
taken in modytied IAEA fashion and volume replentshed with fresh volume rep
solution?

1) Two of each type of defected Turkey

2) Two fuel specimen in solution

Twa of each type of defected solution 2 .

3) Tro of each type of defected Turkey Point fuel specimen in solution?.

Duration: 220 to 250 tays tsome in progressy
Plateout: Yes

Purpose: Study release under high temperature, high pressure candtitans in basalt groundwater

1) Basalt groundwater
$\mathrm{PH}=7.2$ to 8.0 during

amples: Ground
Turkey Point

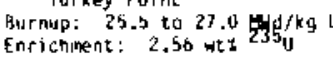

Contalner Material: Gold bay

(within Dickson rocking aut oclave)

Solution Volume: $195 \mathrm{k}$

Run: 1 with

Puration: 55 days
Plateolt: No mention

\section{Wilson 1941}

Wilson and Oversby lyba

Wilson and Overstay 19do
wilson 1965 Schramke, Simbonson
and Coles 1904 


\section{TABLE 2. (contd)}

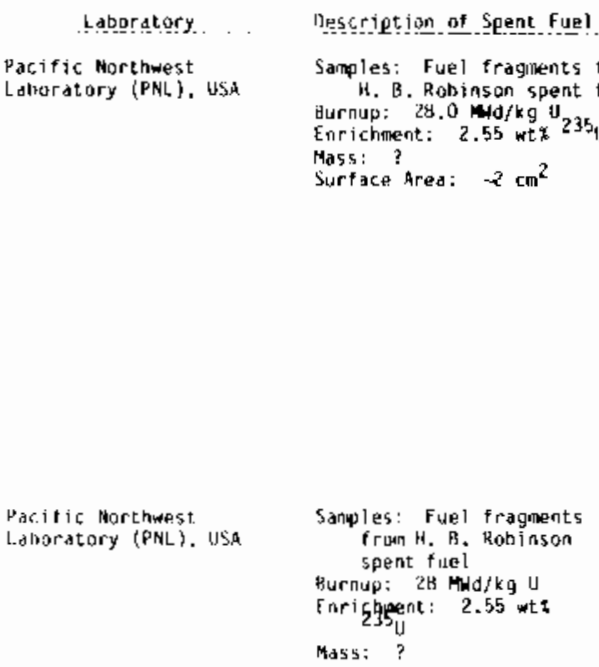
Description of solution(s)
Brinetic Perinian Basin
$\mathrm{pH}=4.65$ to 6.5(
2) Red atmospher
Final $\mathrm{pH}=5.33^{(a)}$
dir atmosphere

Experitnental Procedure dnd Conditions

Purpose: Study the effect of the presence of iran and of temperature on total release Container Material: quartz Solution Yolume: it to $30 \mathrm{~m}$
(10:1 Yolume $5 \mathrm{sa}$ ratio)

Runs:
1) 5 in solution 1 at $25{ }^{\circ} \mathrm{C}$
2) 5 with tron in solution 1 at $2 s^{\circ} \mathrm{C}$

1 in solution 2 at $25^{\circ} \mathrm{C}$
2 in solution 1 at $75^{\circ} \mathrm{C}$

5) with iron in solution 1 at $15^{\circ} \mathrm{C}$ Temps: $25^{\circ} \mathrm{C}$

Ourations: $2,5,14,28$, and 60 days
Plateout: Yes

Purpose: Study mechanisms of spent fuel matrix dissolution

Method: Electrocheinical

Container Material; Pyrex glas

Runs: At least one in each solution

Deionized water
pH $=5,0$

air at mosphere
0.03
$\mathrm{MH}$

air atmosphere
WIPP "B"

Wh
$\mathrm{pH}=6.9(\mathrm{~d})$
----- keferencences

Gray et al. 1 yug

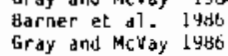

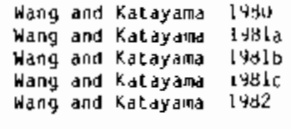

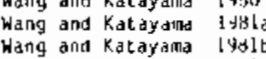
Wany and Kat dyamd $19 y 1$

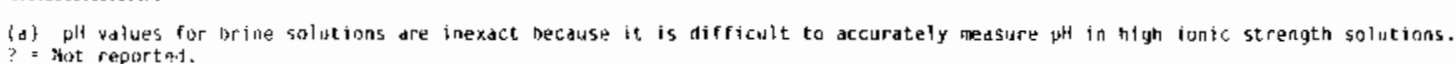


may be of use, however, in observing the formation of alteration phases in a simulated geologic disposal environment and in observing in which phases the various components of the waste form end up after they are released from the waste form.

Table 3 summarizes the studies that have been done on simulated spent fue? . 


\section{TABLE 3. Studies of Release from Simulated Spent Fuel}

\begin{tabular}{|c|c|c|c|c|c|}
\hline Laboratery & $\begin{array}{l}\text { Description of } \\
\text { Spept Fuel.specimen(s) }\end{array}$ & & scription of solution\{s\} & -Experimental Procedure and Conditions & Hefererences \\
\hline $\begin{array}{l}\text { Basals, daste Isolation } \\
\text { Project, USA }\end{array}$ & $\begin{array}{l}\text { Samples: crushed simu- } \\
\text { lated spent fuel }\end{array}$ & 1) & $\begin{array}{l}\text { Synthetic Grande Ronde } \\
\text { Basalt Groundwater } \\
\text { pH = } 6.0 \text { to } 10 \text { during } \\
\text { runs } \\
\text { En = ? }\end{array}$ & 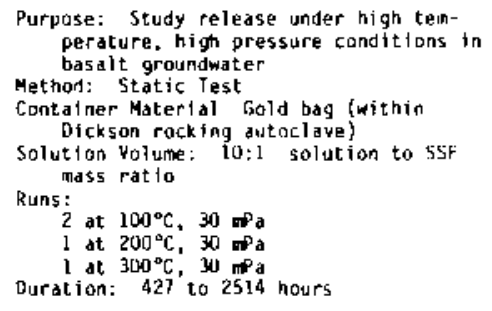 & $\begin{array}{l}\text { Apted and Myers } 1982 \\
\text { Myers, Apted and Mazer } \\
1984 .\end{array}$ \\
\hline Temple University. USA & $\begin{array}{l}\text { Samples: crushed simu- } \\
\text { lated spent fuel } \\
\text { with crushed basalt } \\
\text { rock also present }\end{array}$ & 1) & $\begin{array}{l}\text { Synthet ic Basalt } \\
\text { Graundwater } \\
\text { pH = 6.0 to lol during } \\
\text { runs } \\
\text { Eh = ? }\end{array}$ & 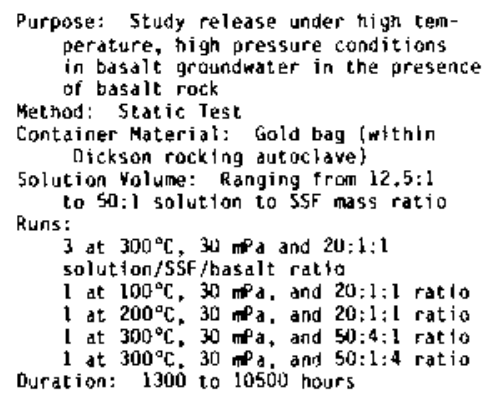 & 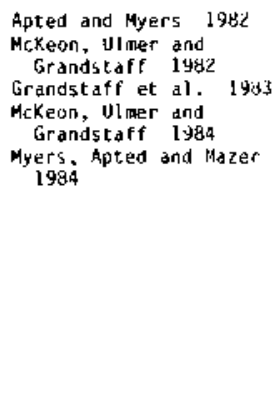 \\
\hline
\end{tabular}

$?=$ Not reported. 
!

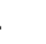




\subsection{THEORETICAL STUDIES OF URANIUM AND ACTINIDE SOLUBILITY}

Much work has been done to develop methods of predicting the solubility of actinide species (uranium in particular) in solutions of various compositions. This work has provided valuable insights into what factors are important in the dissolution of $\mathrm{UO}_{2}$ under a wide range of conditions. The work has proven useful in explaining and interpreting results of tests of radionuclide release from $\mathrm{UO}_{2}$ and spent fuel.

The methods of predicting solubility are all based on fundamental thermodynamic data. These data include standard free energies of formation for each species in the system, and equilibrium constants for each reaction occurring in the system. The reactions include dissolution, complex formation, hydrolysis, dissociation, and redox reactions. Because of the complex chemistry of the actinide elements, this amounts to a great deal of data. Fortunately, several investigators have compiled most of the pertinent data that have appeared in the literature (Smith and Martell 1976; Baes and Mesmer 1976; Rai and Serne 1977; Langmuir 1978; Cleveland 1979; Lemire and Tremaine 1980; Langmuir and Herman 1980; Krupka, Jenne and Deutsch 1983; Lemire 1984).

The thermodynamic data have been used in various ways to arrive at predictions of the equilibrium solubility of uranium and other actinides under various conditions. All of the methods involve the simultaneous solution of the thermodynamic equations that describe the system. This is equivalent to finding the global minimum of the total Gibbs free energy of the system. At equilibrium, all of the expressions describing solubility, complex formation, dissociation, and hydrolysis must be satisfied as well as the Nernst equation for each oxidation or reduction half-reaction as paired with a standard electrode half reaction (Garrels and Christ 1965; Zeleznik and Gordon 1968; van Zeggeren and Storey 1970). Because of the large number of equations that this represents, computer methods are almost always used. Some of the computer codes used to do the complex thermodynamic calculations include SOLMNEQ (Kharaka and Barnes 1973), WATEQ and its later versions (Truesdell and Jones 1974), MINEQL (Westall, Zachary and Morel 1976), PHREEQE (Parkhurst, Thorstenson and Plummer 1980), EQ3/EQ6 (INTERA 1983), MINTEQ (Felmy, Girvin and 
Jenne 1984), and EQ3/6 (Wolery et al. 1985). Solution of the system of equations yields the equilibrium concentrations of each species at a given $\mathrm{pH}$, Eh, temperature, and initial composition of solution.

One of the ways of presenting the results of the above computations is with potential-pH diagrams (Skytte-Jensen 1980; Paquette and Lemi re 1981; Lemire 1984). These diagrams show the most stable species in the system as a function of $\mathrm{pH}$ and Eh. An example of potential-pH diagrams for the $\mathrm{UO}_{2} / \mathrm{water}$ system at different temperatures is given in Figure 1 (from Paquette and Lemire
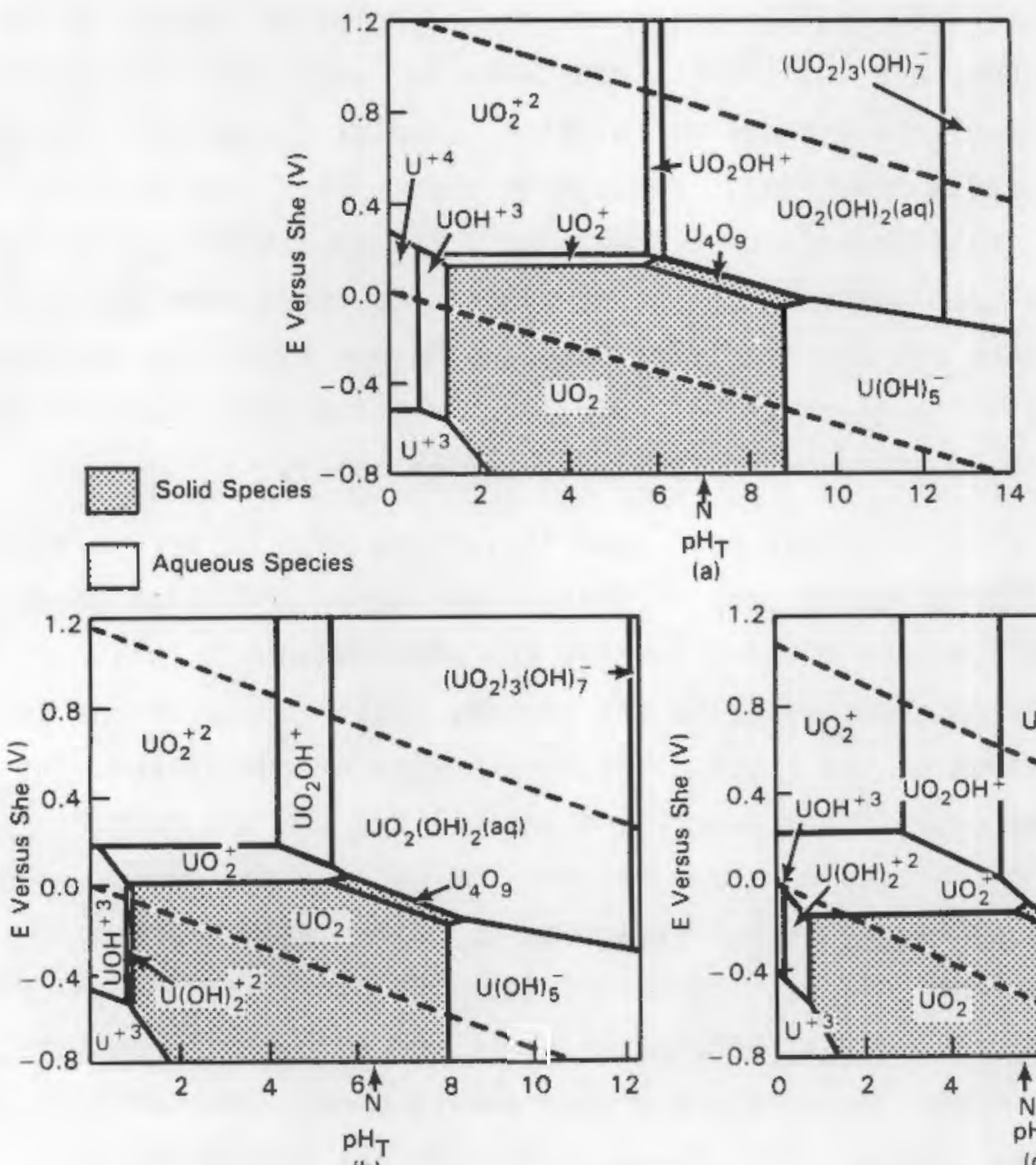

(b)

(c)

FIGURE 1. Potential pH Diagrams for the Uranium/Water System at (a) $25^{\circ} \mathrm{C}$, (b) $100^{\circ} \mathrm{C}$, and (c) $200^{\circ} \mathrm{C}$. Dissolved species activity is $10^{-9}$. Dotted lines represent upper and lower limits of stability of water (Paquette and Lemire 1981). It was later established that the field shown for $\mathrm{U}(\mathrm{OH})_{5}$ is unreasonably large. 
1981). A full treatment of the basis of potential-pH diagrams is given by Pourbaix (1966) and by Garrels and Christ (1965), and an excellent outline of the general principles as applied to actinide species is given by Paquette and Lemire (1981). Contour plotting of isosolubility lines from potential-pH diagrams can provide information on the solubility of various species at different $\mathrm{pH}$ and Eh (Paquette and Lemire 1981).

A shortcoming of potential-pH diagrams is that they provide solubility information on only the most stable species (i.e., those present in highest concentration) as a function of Eh and $\mathrm{pH}$. In many cases, the solubility of the most stable species provides a reasonable approximation to the solubility of all actinide-bearing species (because the other species are present at orders of magnitude lower concentrations), but this is not always the case. For this reason, when actinide solubility is the quantity of interest, most investigators present the results of their calculations as plots or tables of species concentration versus $\mathrm{pH}$ or Eh with all the other variables held constant (Goodwin 1980; Bird 1980; Allard 1982, 1983, 1984a; Duffy and Ogard 1982; Rees 1985). Frequently, the $\mathrm{pH}$ and Eh of a solution are not independent because a reversible reaction is buffering the redox potential of the solution. In this case, the $\mathrm{pH}-$ Eh dependence is described by the Nernst equation for the buffering reaction. An example of a plot of uranium concentration versus $\mathrm{pH}$ where the $\mathrm{Eh}$ is set by magnetite-hematite $\left(\mathrm{Fe}_{3} \mathrm{O}_{4}-\mathrm{Fe}_{2} \mathrm{O}_{3}\right.$ ) equilibria is given in Figure 2 (Goodwin 1980).

At least one team of investigators has attempted to reduce the complexity of solving the large system of equations necessary to predict uranium solubility under various conditions (Garisto and Garisto 1985). They have compiled tables of constants that can be plugged into a formula to calculate total uranium solubility as a function of $\mathrm{pH}$, Eh, temperature, and solution composition. Their model has limits of applicability, however, which they carefully define.

Some of the general limitations of thermodynamic calculations for predicting uranium and actinide solubility are listed below:

- The data base of thermodynamic constants is incomplete and, in many cases, the data that are available have a great deal of uncertainty. 


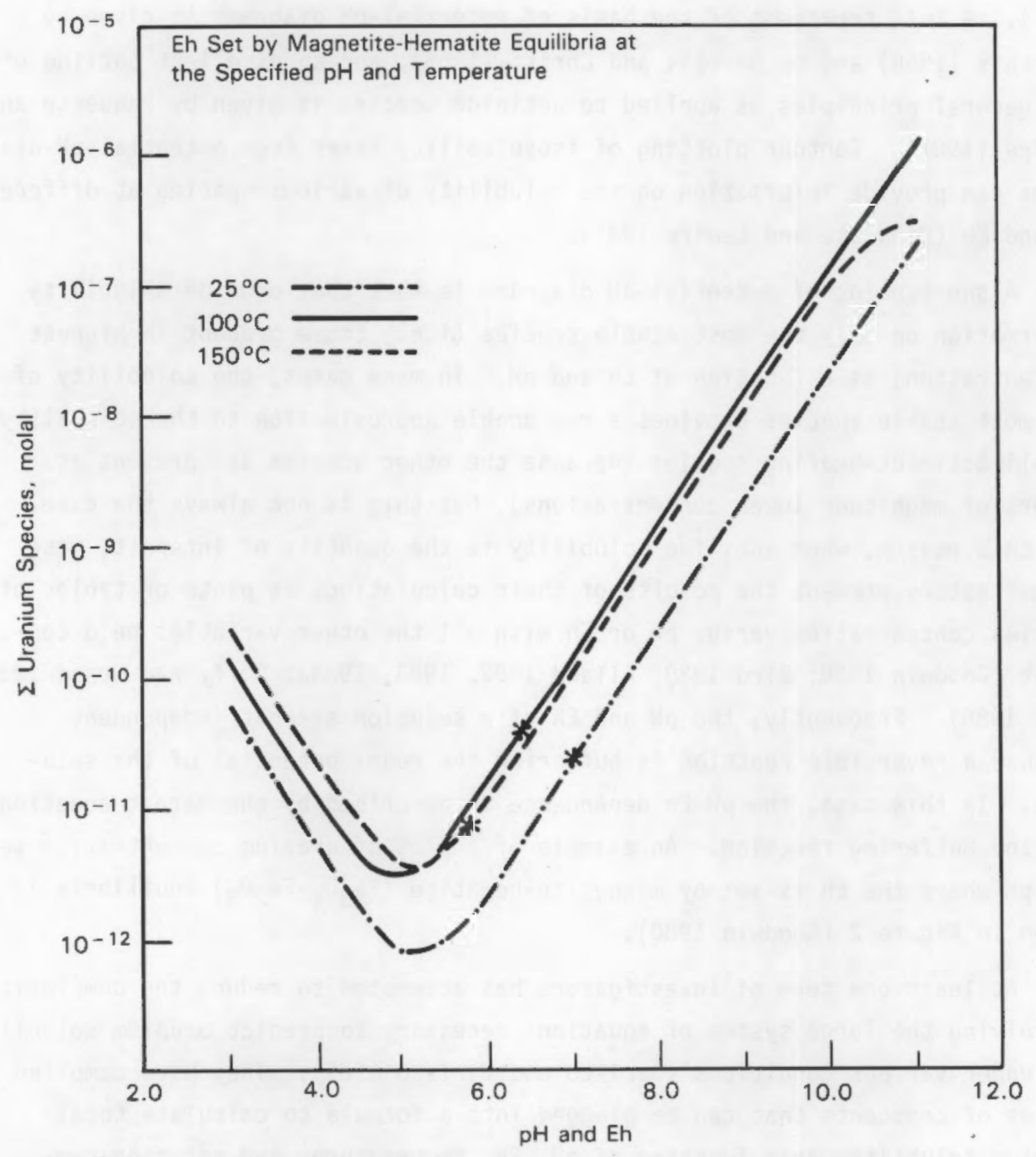

FIGURE 2. Maximum Uranium Solubilities in Brine Ground Water. The abscissa represents the Eh-pH equilibrium boundary of the hematitemagnetite reaction (only $\mathrm{pH}$ values are shown). The asterisks show what is believed to be the natural Eh-pH conditions of the brine at the three temperatures (Goodwin 1980). 
- The thermodynamic calculations predict only equilibrium concentrations--they do not take into account kinetic effects. Some of the geochemical computer codes are capable of calculating reaction kinetics, but much of the kinetic data necessary to do these calculations simply does not exist at the present time. It is possible that under geologic disposal conditions equilibrium will not be attained for thousands of years, and possibly it will never be attained. In this case, the applicability of thermodynamic calculations is limited.

- The thermodynamic calculations do not account for metastable phases. These may be present for indefinite periods of time under geologic disposal conditions.

- The thermodynamic calculations do not account for colloidal species. These have frequently been observed in experimental systems.

- The thermodynamic calculations that have appeared in the literature have dealt almost entirely with actinide-ground-water systems. The situation may be considerably more complex when host rock is included in the system. In this case, thermodynamically stable alteration phases consisting of compounds containing actinides and rock constituents must be considered.

A more complete discussion of these and other limitations is given by Goodwin (1980).

Some of the major conclusions drawn from the theoretical studies of uranium and actinide solubility are:

- The solubility of uranium and the actinides in general is predicted to be lowest in the $\mathrm{pH}$ range 4 to 10 in most solutions. At lower $\mathrm{pH}$ 's, the actinides are apt to be oxidized to more soluble ionic species and/or dissolved by simple acid dissolution. At higher pH's, soluble hydroxyl complexes or other anionic species complexes are more likely to be formed. 
- The solubility of uranium and the actinides is predicted to increase with increasing Eh. This is because the higher oxides of the actinides are generally more soluble than the lower oxides. An exception to this is Plutonium (VI), which can form anionic species that coprecipitate with $\mathrm{Na}^{+}$in brines.

- Temperature has very little effect on the solubility of uranium and the actinides. Its effect is due mainly to the way that it affects the equilibrium constants in the system and the $\mathrm{pH}$ of the solution.

- The solubility of uranium and the actinides is enhanced by the presence of certain anionic species that form complexes with the actinides. These species include $\mathrm{OH}^{-}, \mathrm{HCO}_{3}^{-}, \mathrm{CO}_{3}^{-2}, \mathrm{~F}^{-}, \mathrm{Cl}^{-}, \mathrm{SO}_{4}^{-2}$, $\mathrm{H}_{2} \mathrm{PO}_{4}^{-}, \mathrm{HPO}_{4}^{-2}$, and $\mathrm{PO}_{4}^{-3}$, of which the carbonates and phosphates are the most important. 


\subsection{RESULTS FROM EXPERIMENTAL STUDIES OF RADIONUCLIDE RELEASE FROM URANIUM DIOXIDE AND SPENT FUEL.}

Many experimental studies have been performed to investigate the effects of different variables on the release of radionuclides from $\mathrm{UO}_{2}$ and spent fuel. This section discusses the results of these studies and how well these results agree with what was expected or predicted from theory.

\subsection{GENERAL TRENDS OF RELEASE OF VARIOUS RADIONUCLIDES}

Essentially all of the experimentalists who have studied radionuclide release from spent fuel have observed different rates of release for different radionuclides from spent fuel (see Table 2 for references). Figure 3 shows the release rates of several elements over a three-year period in deionized water at $25^{\circ} \mathrm{C}$ as measured by Katayama, Bradley and Harvey (1980a). To some extent, the different studies listed in Table 2 have yielded conflicting results, but a few basic trends have been observed, which are summarized below.

\subsubsection{Release of Cesium and Iodine}

The fission products cesium- $134\left({ }^{134} \mathrm{Cs}\right)$, cesium-135 ( $\left.{ }^{135} \mathrm{Cs}\right)$, cesium-137 $\left({ }^{137} \mathrm{Cs}\right)$, and iodine-129 ( $\left.{ }^{129} \mathrm{I}\right)$ all release at very high rates initially and then, after a period of a few days to several weeks, they drop off to rates that are comparable to other fission products. ${ }^{99} \mathrm{Tc}$ has also been observed to exhibit this behavior, but the overall release of this radionuclide has generally been slightly lower than that for cesium or iodine (Barner et al. 1985; Wilson 1985). Also, there is less data available for ${ }^{99} \mathrm{TC}$. Certain other radionuclides, such as selenium-79 and carbon-14(a), are also expected to be rapidly released, but there are essentially no data on the release of these elements from spent fuel.

The amount of cesium and iodine released during the initial high release period may be as much as 1 to $5 \%$ of the inventory of these elements. The reason for the high initial release of these elements (and for ${ }^{99} \mathrm{Tc}$ ) has generally

(a) Carbon-14 is an activation product resulting from irradiation of nitrogen impurities in the fuel and from irradiation of $1 \%$. 


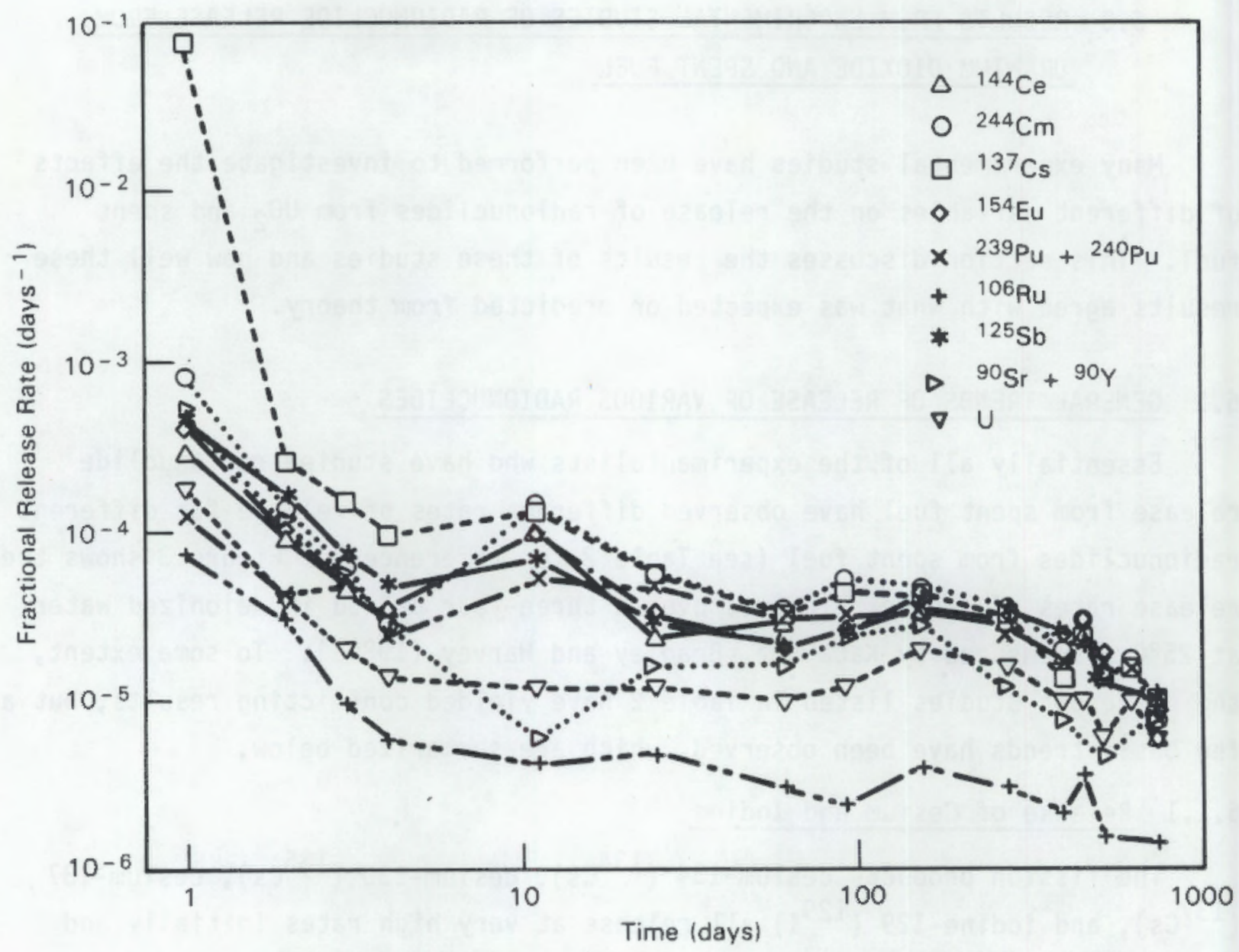

FIGURE 3. Fractional Release Rate of Various Radionuclides from 28.0 MWd $/ \mathrm{kg} U$ Spent Fuel in Deionized Water at $25^{\circ} \mathrm{C}$ (Katayama, Bradley and Harvey 1980a)

been attributed to 1) their relatively high solubility and 2) their tendency to accumulate at exposed surfaces of the fuel during irradiation of the fuel. Regarding the second characteristic, these elements are all very insoluble in the solid $\mathrm{UO}_{2}$ matrix (i.e., they are not easily incorporated into the matrix as oxides or otherwise) and, upon forming, they tend to migrate to grain boundaries or cracks in the fuel and/or down the temperature gradient to the periphery of the fuel. Because these elements are not bound to the $\mathrm{UO}_{2}$ matrix and because the cracks, grain boundaries, and the outer periphery of the fuel are the first surfaces to come in contact with the solution during radionuclide release testing, these elements are very rapidly released from the fuel. 
In addition to being observed in the studies of radionuclide release from spent fuel presented in Table 2, the rapid release of cesium and iodine has been studied by several other investigators (Peehs et al. 1978; Devell and Hesbol 1978; Lorenz et al. 1980; Peehs et al. 1980; Peehs, Kaspar and Neeb 1983). These studies were concerned with the release of cesium and iodine from failed fuel pins (i.e., pins with ruptured cladding) to reactor core water or water storage pools at reactor sites. The results from all of the studies mentioned in this section suggest that the amount of radionuclides that are rapidly released is dependent on conditions that prevailed during irradiation rather than on conditions that prevailed during the release tests themselves.

Some attempts have been made by Canadian investigators to correlate the amount of cesium and iodine released during the initial rapid release period to the amount of the gaseous fission product xenon released from the fuel (Johnson et al. 1983; Johnson et al. 1984). There are reasons to believe that the gap and grain boundary inventories of cesium and iodine are correlated with the noble gas inventory in the gap and grain boundaries. The amount of xenon released (i.e., in the gap) can be predicted using the Canadian computer code, ELESIM, which calculates the release based on the power history of the fuel (Notley 1979). These efforts to correlate cesium and iodine release to xenon release have met with modest success.

\subsubsection{Release of Other Fission Products and Actinides}

Most fission products (other than cesium and iodine) and actinides (including uranium) all tend to be released from the spent fuel matrix at initially lower rates than either cesium or iodine. This has generally been attributed to the inclusion of these elements in the $\mathrm{UO}_{2}$ matrix as solid compounds, generally oxides. Once incorporated in the matrix, the migration of these elements is prevented or retarded. It has been widely proposed that the release of these elements is controlled by dissolution of the $\mathrm{UO}_{2}$ matrix.

Some investigators have argued that fission products and actinides are released from the $\mathrm{UO}_{2}$ matrix congruently with uranium, but many studies have produced results that suggest that some elements are released at slightly higher rates than uranium (i.e., they are preferentially leached). There is little agreement on the relative order of release rates for the different 
elements, but in general, the fission products have been observed to be released slightly faster than the actinides. The latter are released at about the same rate as uranium.

\subsection{EFFECT OF SOLUTION COMPOSITION AND CHEMICAL SPECIES ON RADIONUCLIDE RELEASE}

The effects of different solution compositions on the release rates of various elements from spent fuel and $\mathrm{UO}_{2}$ have been investigated in several studies (see Table 2). The most commonly used liquids have been deionized and/or distilled water and solutions that simulate ground waters from proposed geologic repository sites. The latter include brines, granite ground waters, basalt ground waters, and tuff ground waters. A few studies have been done using salt solutions (e.g., sodium chloride and calcium chloride) and carbonate/bicarbonate solutions.

In general, solution composition has been observed to have a greater effect on the release rates of radionuclides that are incorporated in the $\mathrm{UO}_{2}$ matrix than on the release rates of radionuclides that are present at the exposed surfaces of the fuel (e.g., cesium and iodine). To illustrate this, Figures 4 and 5 show the release rates of ${ }^{137} \mathrm{Cs}$ and Curium-244 $\left({ }^{244} \mathrm{Cm}\right)$, respectively, in the same five solutions (Katayama, Bradley and Harvey 1980a). Curium is expected to be incorporated in the $\mathrm{UO}_{2}$ matrix as an oxide, and it is apparent that its release rate is more affected by solution composition than is the release rate of cesium. This suggests that the main effect of solution composition is on the degradation rate of the $\mathrm{UO}_{2}$ matrix.

The results for uranium (especially in deionized water and carbonate water) are somewhat contradictory, which makes the assertion that solution composition affects $\mathrm{UO}_{2}$ on matrix dissolution difficult to support. Johnson (1982) observed that uranium dissolved faster from spent fuel in carbonate ground water than in air-saturated distilled water. This is in agreement with experimental studies of unirradiated $\mathrm{UO}_{2}$, which show enhanced solubility in carbonate solutions due to the formation of uranyl carbonate complexes (Wang 1981). Eklund and Forsyth (1978), however, used the same carbonate ground water as Johnson and observed no difference between the release rate of uranium 


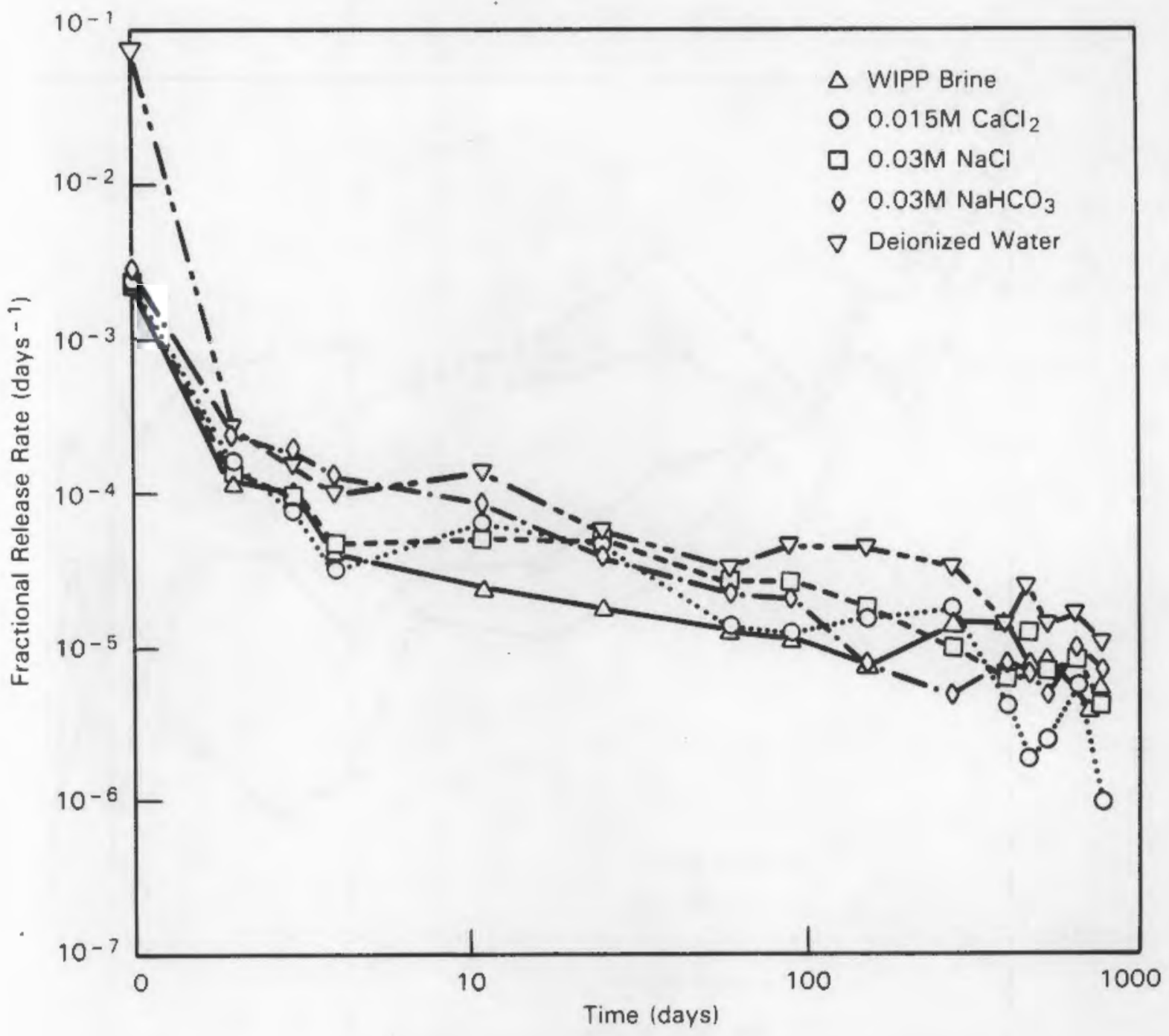

FIGURE 4. Fractional Release of ${ }^{137} \mathrm{Cs}$ from $28 \mathrm{MWd} / \mathrm{kg} \mathrm{U}$ Spent Fuel in Various Solutions at $25^{\circ} \mathrm{C}$

(Katayama, Bradley and Harvey 1980a)

in distilled water and carbonate water. Katayama, Bradley and Harvey (1980a) observed higher uranium release rates in air-saturated deionized water than in any of the other solutions that they studied, including $0.03 \mathrm{M} \mathrm{NaHCO}_{3}$.

Very few explanations have been offered for the conflicting uranium behavior in these experiments. Wang and Katayama (1981b) have suggested that radiolysis may have played a role in the Katayama experiments. They note that the $\mathrm{pH}$ drop that was observed in all the solutions during the course of the experi-. ments was much greater in deionized water than in the other solutions. They 


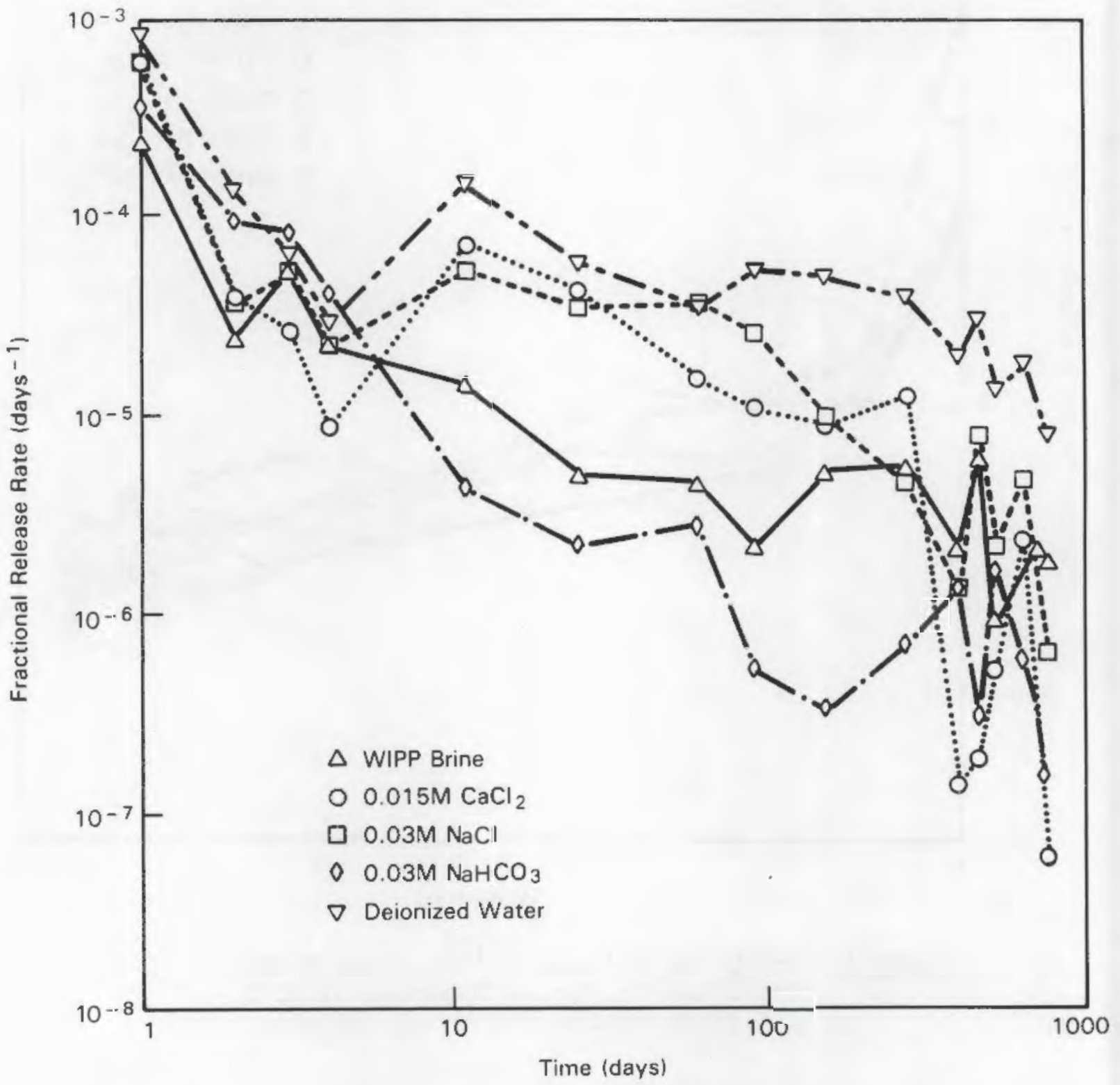

\section{FIGURE 5. Fractional Release Rate of ${ }^{244} \mathrm{Cm}$ from $28.0 \mathrm{MWd} / \mathrm{kg} \mathrm{U}$ Spent Fuel in Various Solutions at $25^{\circ} \mathrm{C}$ (Katayama, Bradley and Harvey 1980a)}

attribute this to the radiolysis-induced formation of nitric acid (with nitrogen coming from air). The $\mathrm{pH}$ drop, which enhances the solubility of $\mathrm{UO}_{2}$, was not so dramatic in the other solutions because they were buffered by other constituents. Johnson et al. (1981) point out that the results of spent fuel radionuclide release experiments with respect to uranium can be affected by the 
degree to which uranium precipitates within the experimental system or adsorbs back onto the surface of the spent fuel if these phenomena are not accounted for.

The issue of how solution composition affects radionuclide release from spent fuel will probably not be resolved until there is a better understanding of two factors: 1) how the solutions are affected by the radiation field from spent fuel, and 2) what the disposition of uranium is in different solutions after it has been released from the waste form.

\subsection{EFFECT OF TEMPERATURE ON RADIONUCLIDE RELEASE}

Temperature is predicted to have very little effect on the solubility of $\mathrm{UO}_{2}$, and it has been observed to have little effect on release rates and cumulative release from spent fuel. Slight increases in release rates of certain elements have been observed in systems in which the temperature was increased during the course of experimental runs (Norris 1979b; Johnson et al. 1982). The increased rates, however, rapidly decayed to rates that were the same as or below the rates observed before the temperature was increased. The cumulative release in these experiments was not noticeably affected by the temperature changes, which is in agreement with the work of Barner et al. (1986), who studied cumulative release from spent fuel in brines at $25^{\circ} \mathrm{C}$ and $75^{\circ} \mathrm{C}$.

\subsection{EFFECT OF $\mathrm{PH}$ ON RADIONUCLIDE RELEASE}

The effect of $\mathrm{pH}$ on radionuclide release from spent fuel has not been studied in detail because most spent fuel studies have been done using deionized water or simulated ground waters at their natural pH. Results from experimental studies of $\mathrm{UO}_{2}$ dissolution and uranium solubility and from the theoretical work discussed in Section 5.0, however, suggest that $\mathrm{UO}_{2}$ dissolution rates and uranium solubilities should be lowest in the $\mathrm{pH}$ range of 5 to 10. All of the solutions that have been used with spent fuel fall into this range.

Figure 6 shows uranium release rates from $\mathrm{UO}_{2}$ as a function of $\mathrm{pH}$ as measured by Thomas and Til1 (1984). Figure 7 shows the measured solubility of uranium in 0.001 M NaCl as a function of $\mathrm{pH}$ (Silva and Yee 1981). 


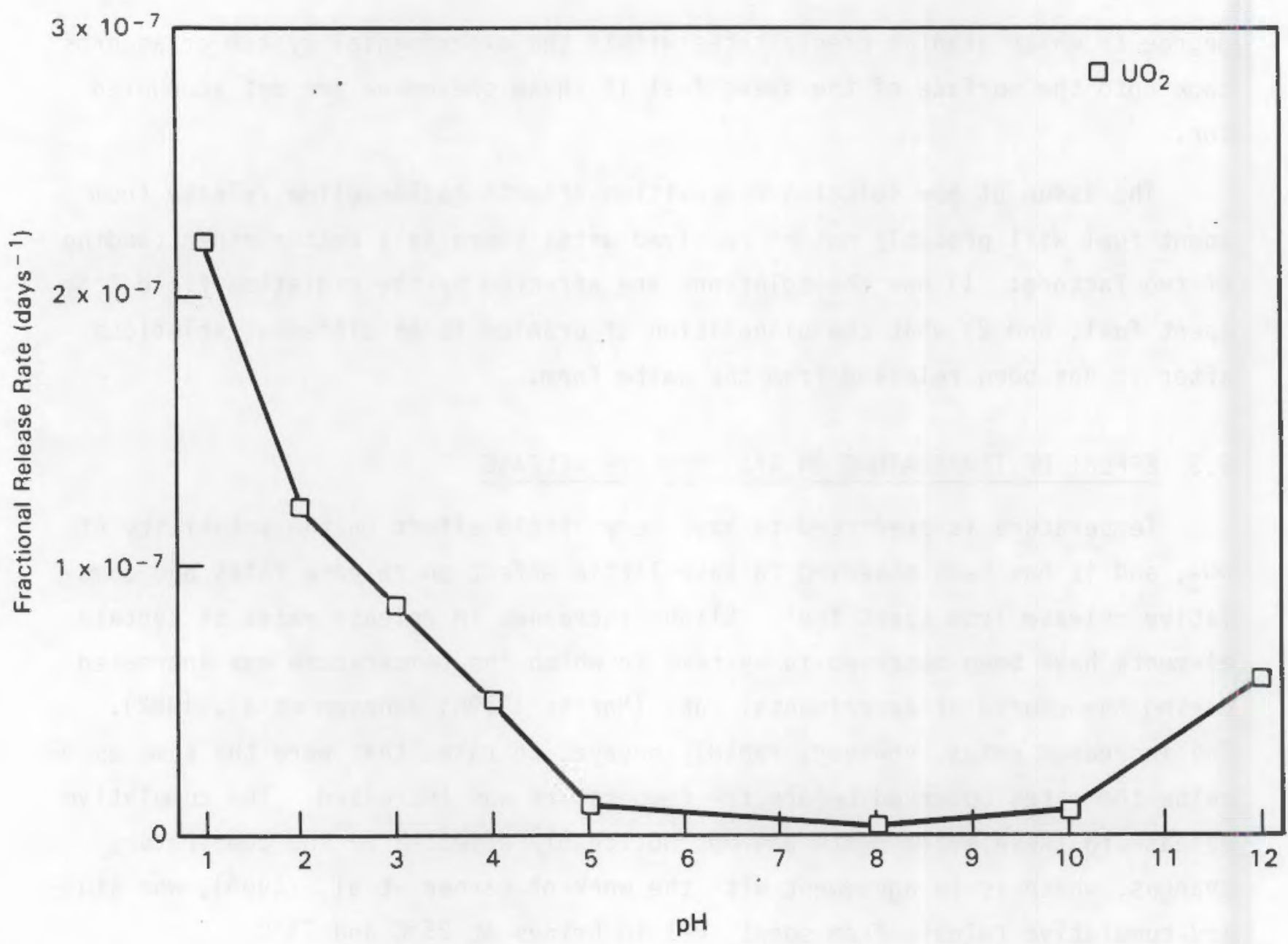

FIGURE 6. Fractional Release Rate of Uranium from Unirradiated $\mathrm{UO}_{2}$ Pellets as a Function of pH (Thomas and Till 1984)

\subsection{EFFECT OF OXYGEN CONCENTRATION AND Eh ON RADIONUCLIDE RELEASE}

Several investigators have studied the effect of oxygen concentration and Eh on radionuclide release from spent fuel and $\mathrm{U}_{2}$. The results indicate that release rates and total release for most elements are greater in oxidizing solutions than in reducing solutions. This has been attributed to the fact that under oxidizing conditions, the surface of the $\mathrm{UO}_{2}$ matrix reacts to form higher oxides of uranium, which are much more soluble than $\mathrm{U}_{2}$ under most conditions. One of these higher oxide species, the uranyl ion $\left(\mathrm{UO}_{2}{ }^{+2}\right)$ complexes 


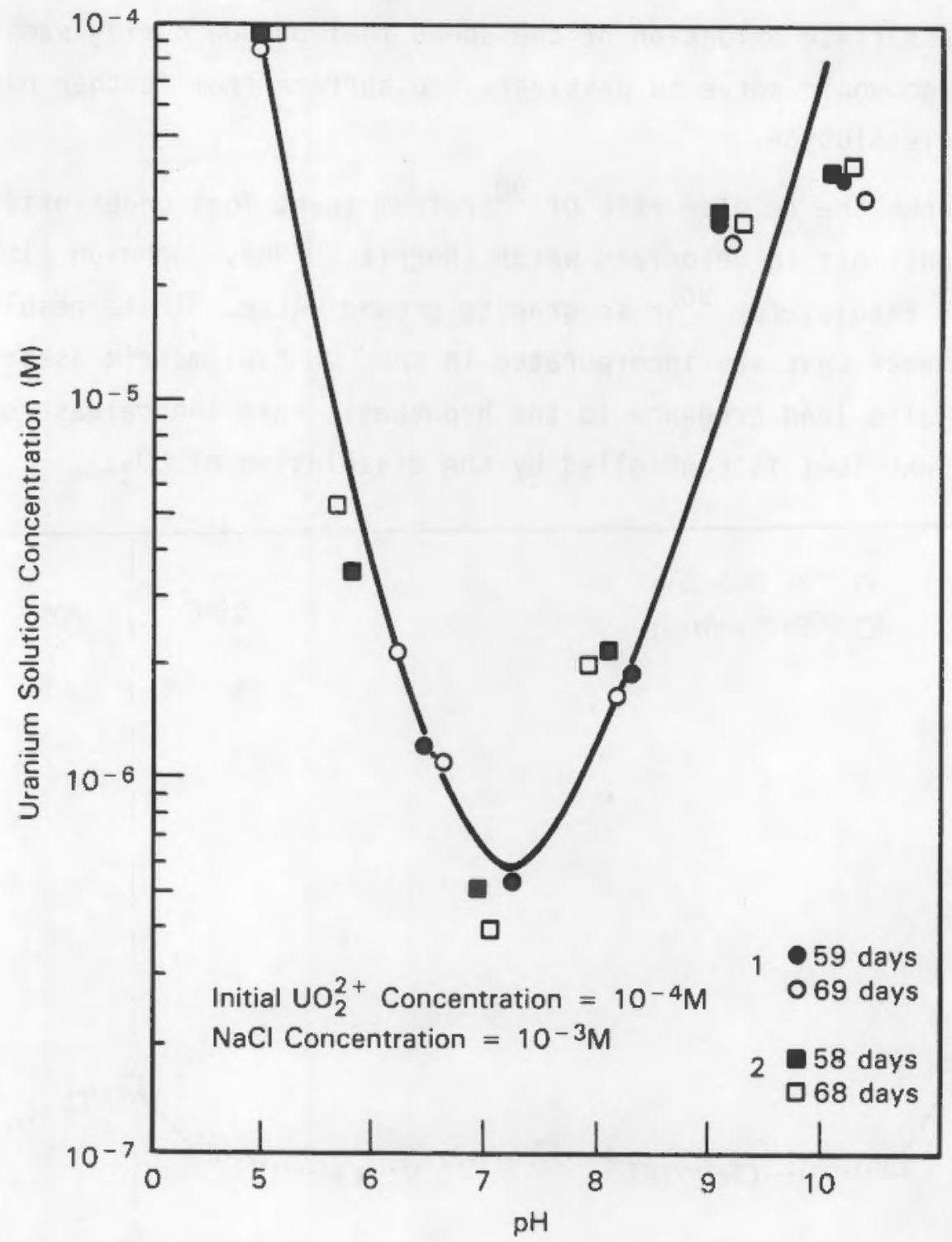

FIGURE 7. Uranium Solution Concentration as a Function of $\mathrm{pH}$ at $23^{\circ} \mathrm{C}$. Points represent experimental results (Silva and Yee 1981)

readily with many anions. This species and its hydrolysis products are believed to be the most prevalent uranium species in solution under disposal conditions.

The release rate dependency on oxygen concentration is generally less than what would be expected if the dependence were first-order. This could possibly 
be attributed to surface oxidation of the spent fuel or $\mathrm{UO}_{2}$ during sample preparation, which would serve to passivate the surface from further oxidation and consequent dissolution.

Figure 8 shows the release rate of ${ }^{90} \mathrm{Sr}$ from spent fuel under oxidizing and reducing conditions in deionized water (Norris 1979b). Johnson (1982) observed similar results for ${ }^{90} \mathrm{Sr}$ in granite ground water. These results are typical for elements that are incorporated in the $\mathrm{UO}_{2}$ fuel matrix as solid compounds. The results lend credence to the hypothesis that the release of these elements from spent fuel is controlled by the dissolution of $\mathrm{NO}_{2}$.

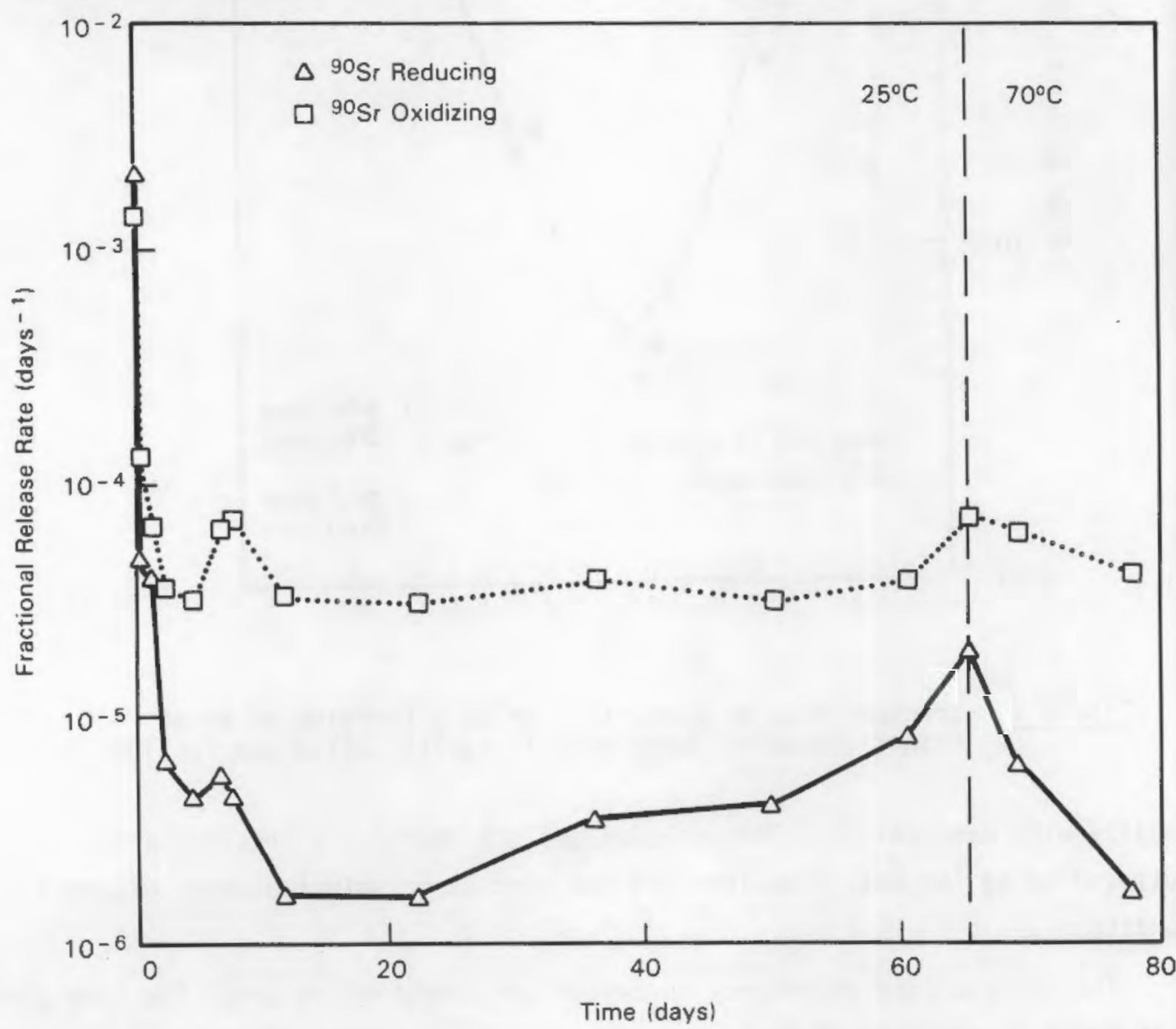

FIGURE 8. Fractional Release Rate of ${ }^{90} \mathrm{Sr}$ from $28.0 \mathrm{MWd} / \mathrm{kg}$ U Spent Fuel
Under Reducing and Oxidizing Conditions (Norris 1979b) 
Figure 9 shows the release rate of ${ }^{137} \mathrm{Cs}$ from spent fuel as measured under oxidizing and reducing conditions (Norris 1979b). The fact that there is very little difference between the release rates under the two conditions suggests that the release of cesium is not controlled by the dissolution of $\mathrm{UO}_{2}$; this is the expected result because cesium does not go into solid solution with $\mathrm{U}_{2}$.

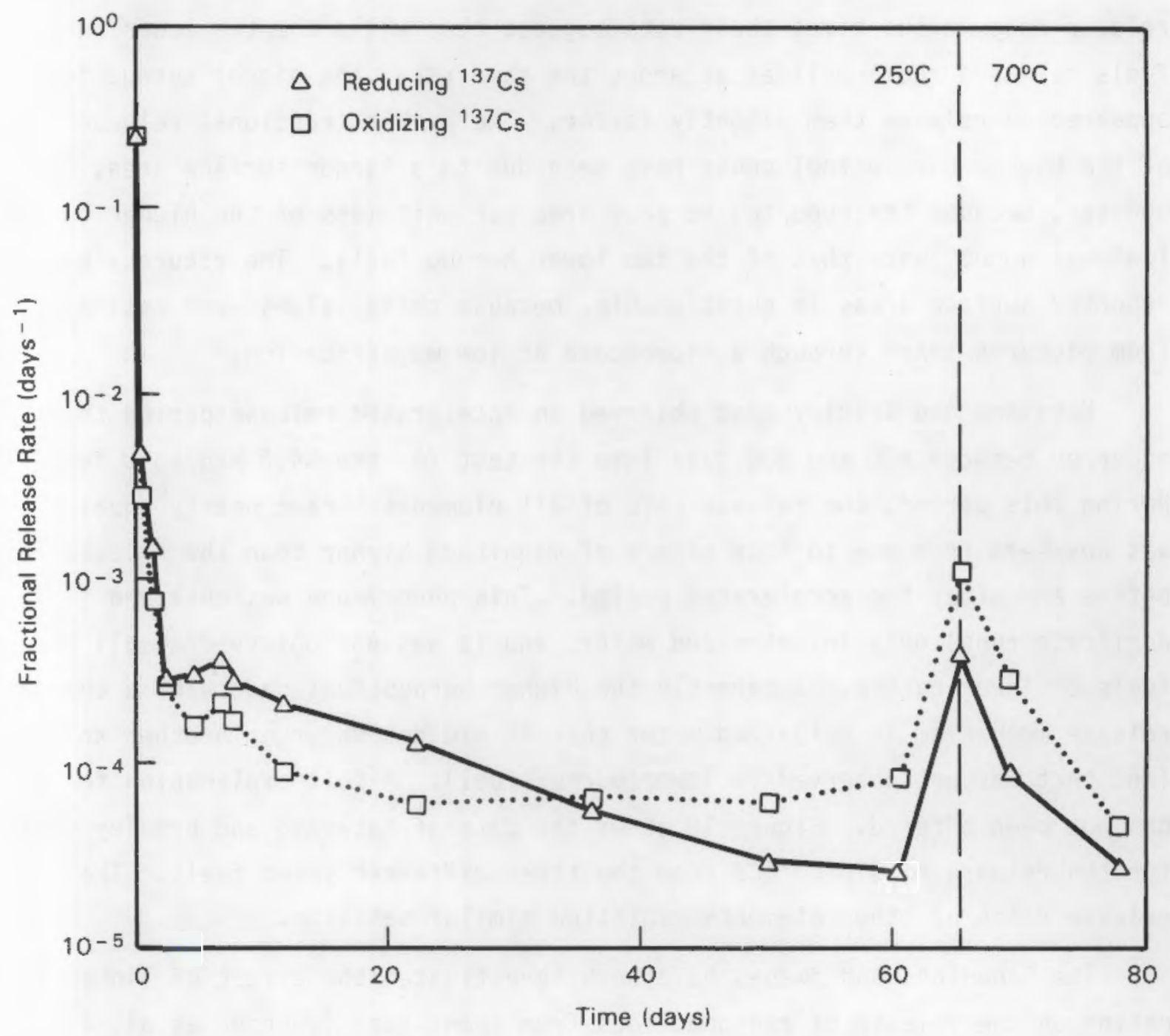

FIGURE 9. Fractional Release Rate of ${ }^{137} \mathrm{Cs}$ from $28.0 \mathrm{MWd} / \mathrm{kg} \mathrm{U}$ Spent Fuel Under Reducing and Oxidizing Conditions (Norris 1979b) 


\subsection{EFFECT OF FUEL IRRADIATION HISTORY ON RADIONUCLIDE RELEASE}

The effect of fuel irradiation history (burnup and linear power rating) on radionuclide release from spent fuel has not been studied in great detail. Katayama and Bradley (1980) conducted modified IAEA tests on fuels with burnups of $9.0,28.0$ and $54.5 \mathrm{MWd} / \mathrm{kg} \mathrm{U}$, and they concluded that there was no discernable effect of burnup on long-term release rate. When plotted as fractional release rate versus time, their data suggest that while the two lower burnup fuels released radionuclides at about the same rate, the higher burnup fuel appeared to release them slightly faster. The faster fractional release rate of the higher burnup fuel could have been due to a larger surface area, however, because the reported surface area per unit mass of the higher burnup fuel was about twice that of the two lower burnup fuels. The accuracy of the reported surface areas is questionable, because these values were estimated from pictures taken through a microscope at low magnification.

Katayama and Bradley also observed an accelerated release period that occurred between 600 and 800 days into the test for the $54.5 \mathrm{MWd} / \mathrm{kg} U$ fuel. Ouring this period, the release rate of all elements became nearly equal and was anywhere from one to four orders of magnitude higher than the release rates before and after the accelerated period. This phenomenon was observed (in duplicate runs) only in deionized water, and it was not observed at all for fuels of lower burnup. Apparently the higher burnup fuel underwent a change of release mechanism in deionized water that it did not undergo in other solutions (and that was not observed in lower burnup fuel). A full explanation for this has not been offered. Figure 10 shows the data of Katayama and Bradley (1980) for the release rate of ${ }^{137}$ Cs from the three different spent fuels. The release rates of other elements exhibited similar behavior.

The Canadians and Swedes have both investigated the effect of linear power rating on the release of radionuclides from spent fuel (Johnson et al. 1982; Eklund and Forsyth 1978). The results indicate that the release of radionuclides that do not go into solid solution with $\mathrm{UO}_{2}$ (e.g., cesium and iodine) are enhanced by a higher power rating, while the release of radionuclides that go into solid solution with $\mathrm{UO}_{2}$ are much less affected by power rating. An 


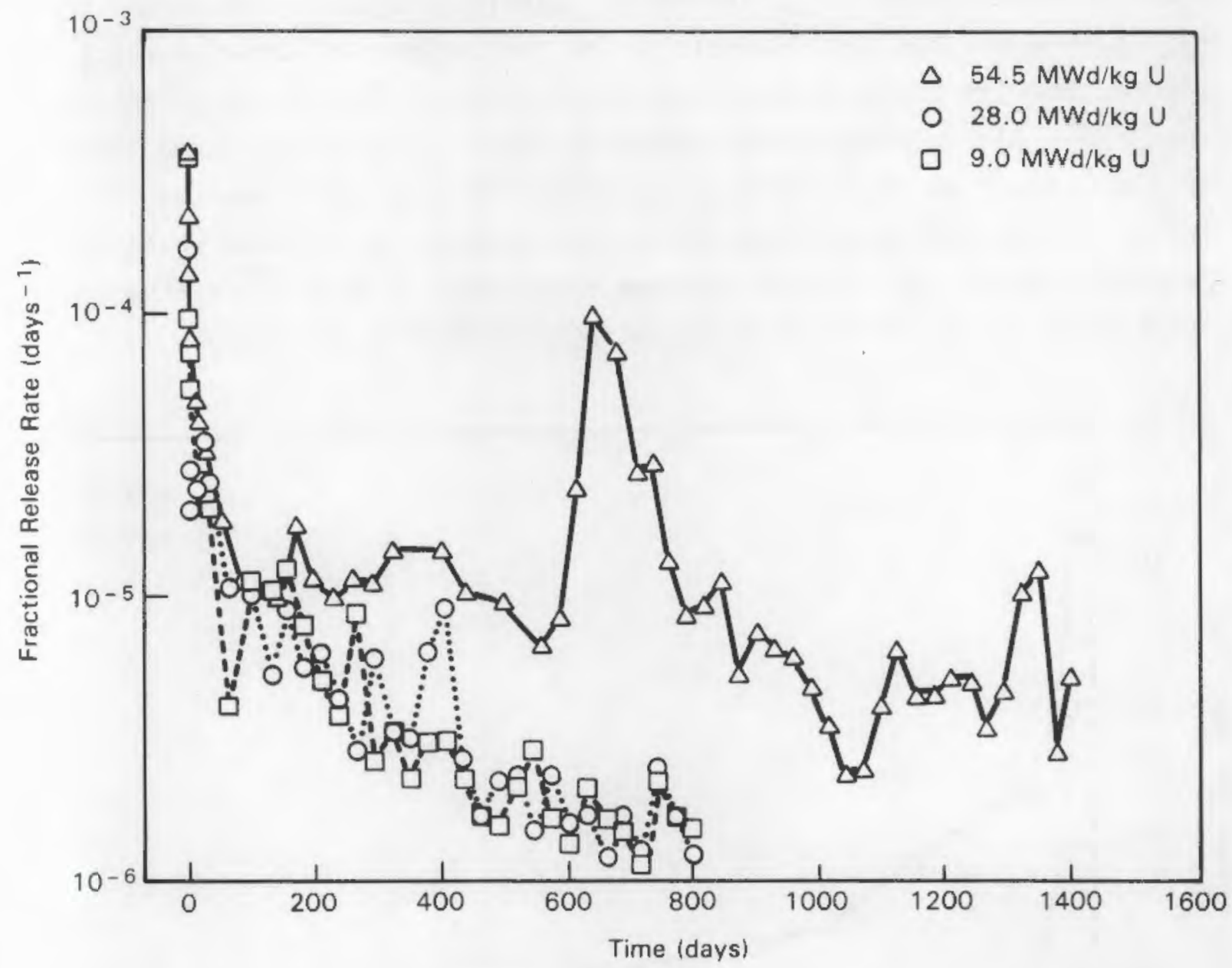

FIGURE 10. Fractional Release Rate of ${ }^{137} \mathrm{Cs}$ from Spent Fuels with Burnups of $9.0,28.0$, and $54.5 \mathrm{MWd} / \mathrm{kg} U$ in Deionized Water at $25^{\circ} \mathrm{C}$ (Katayama and Bradley 1980 ). The reported surfacearea-per-unit-mass of the three fuel samples were 1.16 , 0.99 , and $2.28 \mathrm{~cm}^{2} / \mathrm{g}$ for the $9.0,28.0$ and $54.5 \mathrm{MWd} / \mathrm{kgU}$ fuels, respectively.

exception to this was observed by Eklund and Forsyth (1978) for ${ }^{90} \mathrm{Sr}$, which exhibited a higher release rate from fuel with a higher power rating even though strontium is known to form oxides in the $\mathrm{UO}_{2}$ matrix.

Some of the observed dependence of release rates on linear power rating may be caused by differences in the surface area of the various fuel samples used in the experiments. Unfortunately, neither the Canadians nor the Swedes reported the surface areas of their samples. The fact that the release of 
radionuclides that do not go into solid solution with $\mathrm{UO}_{2}$ is dependent on power rating, however, can also be explained by the tendency of these elements to migrate down the radial temperature gradient of the fuel during irradiation. A fuel with a higher power rating generally has a larger radial temperature gradient, which serves to enhance the migration of elements such as cesium and iodine to the grain boundaries and exposed surfaces of the fuel where they can be readily dissolved. Figure 11 shows the release rate of ${ }^{137}$ Cs from Canadian spent fuels of two different power ratings (Johnson et al. 1982).

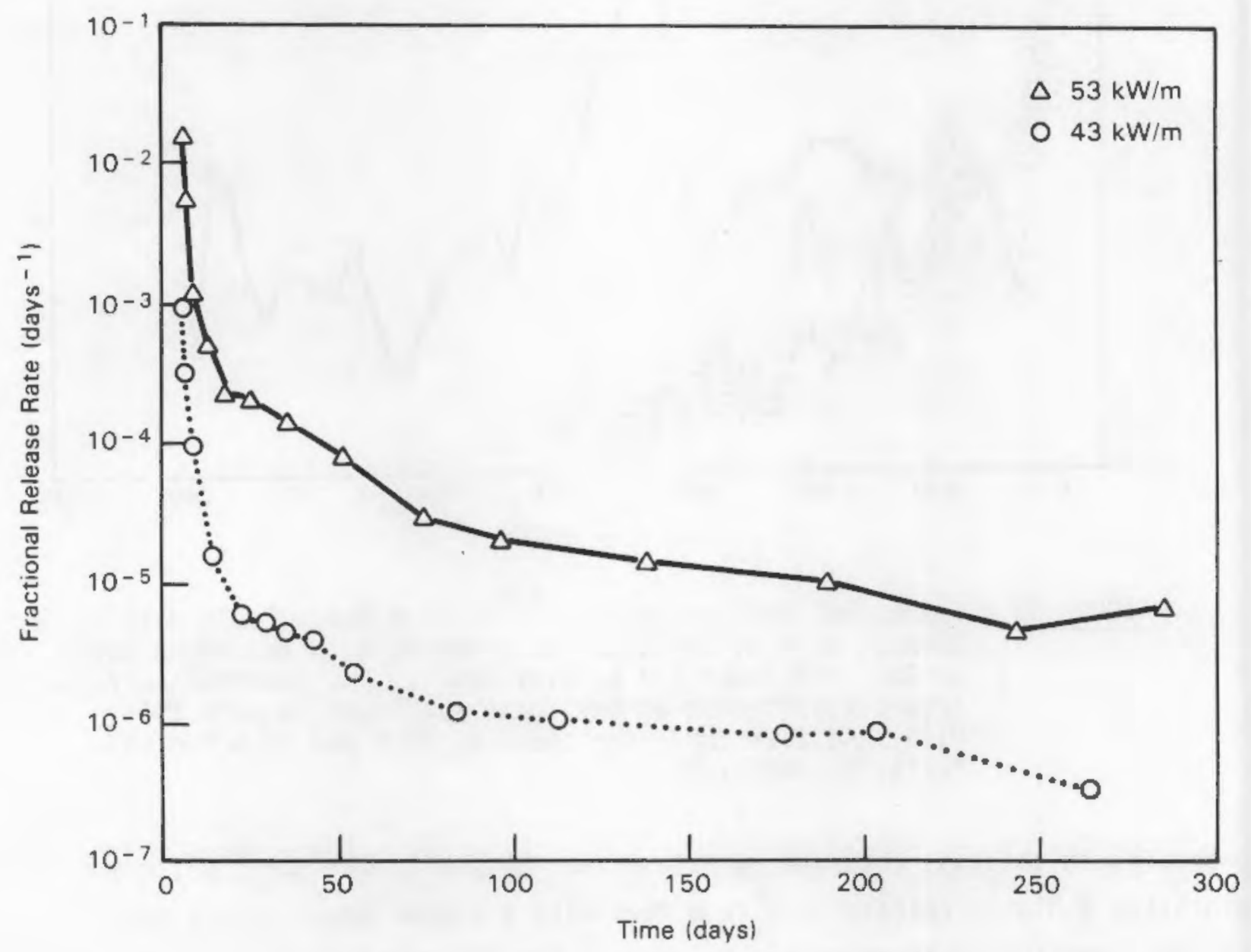

FIGURE 11. Fractional Release Rate of ${ }^{137}$ Cs from Spent Fuels with Moderate and High Power Ratings (Johnson et al. 1982). Surface areas were not reported. 


\subsection{CREDIT FOR CLADDING CONTAINMENT}

A series of studies has been conducted at Westinghouse Hanford Company with the intent of showing that the cladding that surrounds spent fuel rods can significantly hinder the release of radionuclides from the spent fuel, even when the cladding is defected (Wilson and Oversby 1984, 1985; Wilson 1985). Defects in the cladding can occur during reactor operation or during postirradiation handling. This work is being done for the tuff repository project, which is managed by the Nevada Nuclear Waste Storage Investigations (NNWSI). Dissolution tests have been performed on sections of $\mathrm{clad}$ spent fuel rods that have been capped on the ends with stainless steel fittings. The specimens have had cladding in the following conditions:

- No defects (cladding completely intact)

- Two 0.2-mm laser-drilled holes in the cladding

- One slit defect cut in the cladding, 2 to $2.5 \mathrm{~cm}$ long by 0.15 to $0.2 \mathrm{~mm}$ wide

- Cladding completely removed.

The results of these tests have indicated that the defected cladding does hinder the release of uranium and plutonium to the test solutions, but that it has little effect on the release of cesium to the solutions (except when the cladding is intact, in which case essentially no cesium is released). The defected cladding provided retardation of the release of cesium, but after 30 days the amount of cesium in solution was about the same as in the cases where the cladding was completely removed. The tests simulated low repository flow rates; each sample of solution removed for analysis was replenished by an equal volume of fresh solution. Figures 12 and 13 show the fraction of total uranium and cesium inventory in solution at each sampling time for each of the four types of specimens. Well water from the Nevada repository site was used as the solution in these tests.

The main problem with taking credit for cladding containment in predicting the release of radionuclides from spent fuel is that it is very difficult to characterize the disposal condition of the cladding. There is currently no way of predicting a priori what types of defects the cladding will have or what 


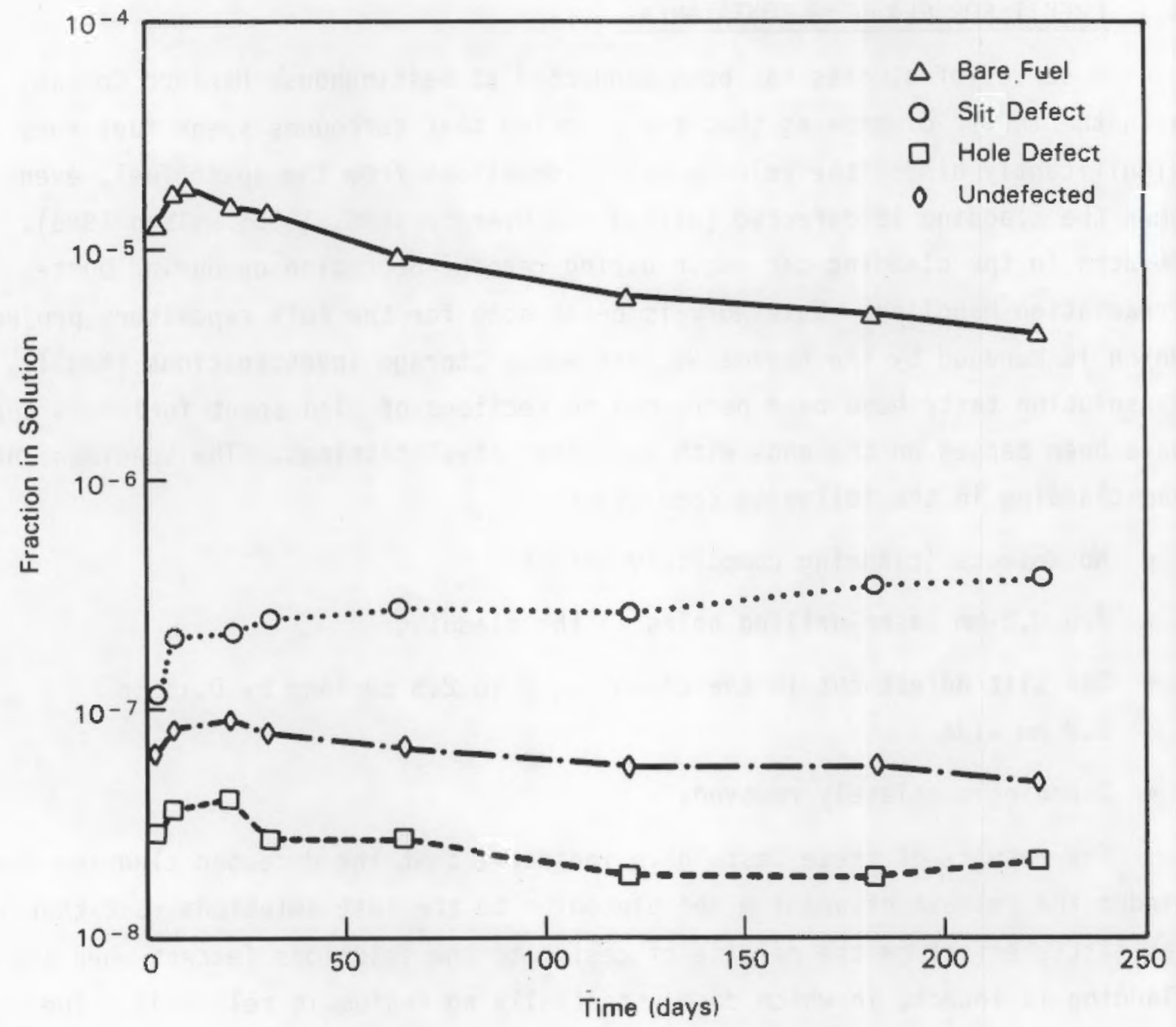

FIGURE 12. Fraction of Uranium Inventory in Solution for $31 \mathrm{MWd} / \mathrm{kg} \mathrm{U}$ PWR Spent Fuel with Various Cladding Defects in Yucca Mountain Well Water at $25^{\circ} \mathrm{C}$ (Wilson and Oversby 1985)

percentage of fuel rods will have these defects. For this reason, most performance assessment studies of spent fuel waste packages have taken the conservative approach of assuming that all cladding has failed and that the waste form is essentially bare fuel. 


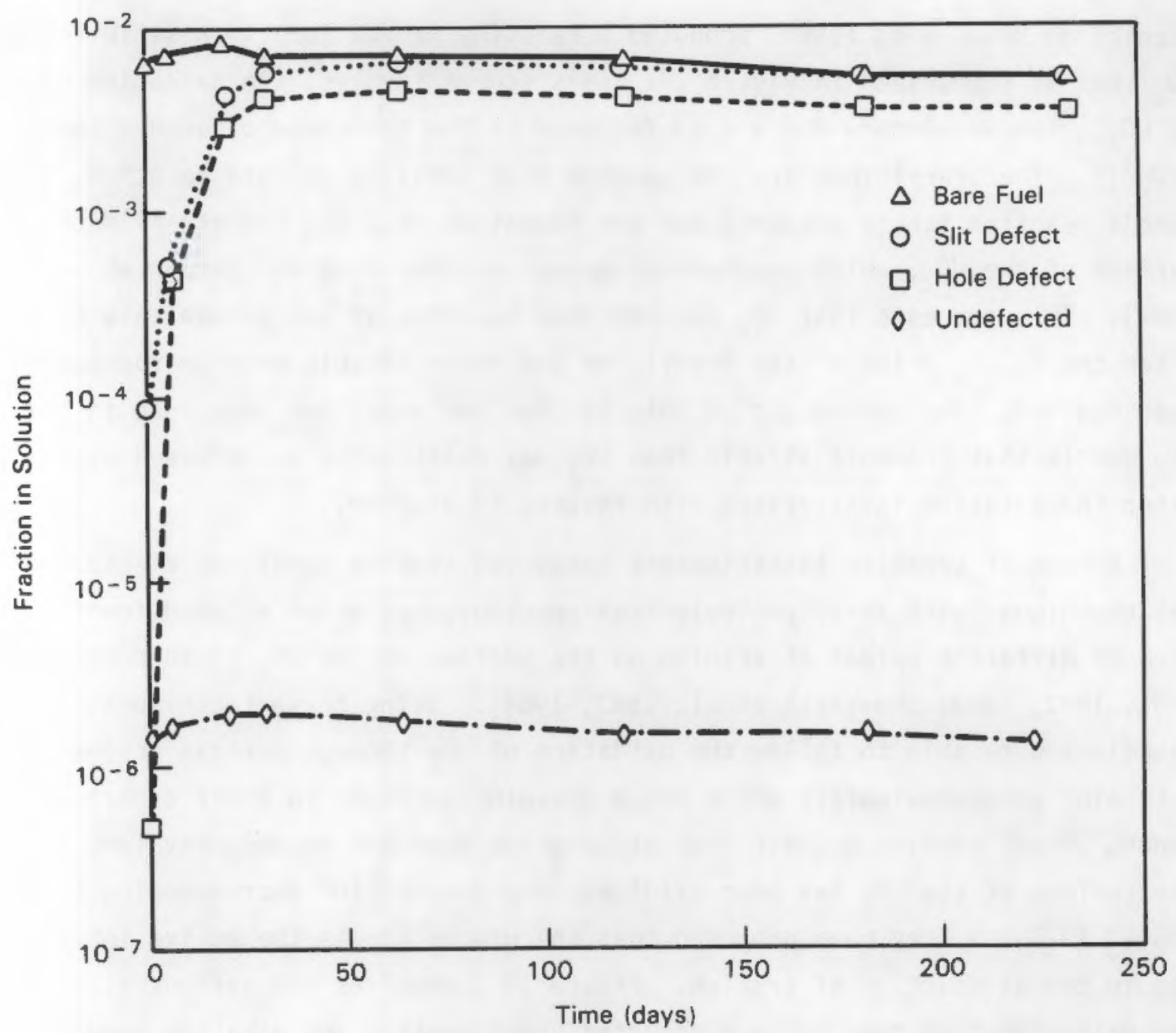

FIGURE 13. Fraction of ${ }^{137} \mathrm{Cs}$ Inventory in Solution for $31 \mathrm{MWd} / \mathrm{kg} \mathrm{U}$ PWR Spent Fuel with Various Cladding Defects in Yucca Mountain We11 Water at $25^{\circ} \mathrm{C}$ (Wilson and Oversby 1985)

\subsection{MECHANISMS OF OXIDATION AND DISSOLUTION}

Because the solubility of $\mathrm{UO}_{2}$ in neutral and alkaline solutions is much lower under reducing conditions than under oxidizing conditions, it is widely believed that the dissolution of $\mathrm{UO}_{2}$ involves first its oxidation and then the dissolution of the oxidized species.

Mechanisms of the oxidation and dissolution of spent fuel have been postulated mainly by experimentalists who have conducted electrochemical dissolution 
studies on $\mathrm{UO}_{2}$. Wang (1981) proposed a reaction scheme for the dissolution of $\mathrm{UO}_{2}$ that is summarized in Figure 14. This scheme involves the oxidation of $\mathrm{UO}_{2}$ to $\mathrm{UO}_{2+x}$ species (where $0<x \leq 1$ ) followed by the formation of uranyl ions $\left(\mathrm{UO}_{2}{ }^{+2}\right)$. The uranyl ions are the species that actually go into solution. Wang's reaction scheme accounts for the formation of a $\mathrm{UO}_{3}$ hydrate film on the surface of the $\mathrm{UO}_{2}$, which has been observed in other studies (Sunder et al. 1982). This suggests that $\mathrm{UO}_{2}$ may continue to dissolve and precipitate even after the solubilities of the uranyl ion and other soluble uranium species have been reached. The end result of this is that radionuclides contained in the $\mathrm{UO}_{2}$ matrix that are more soluble than $\mathrm{UO}_{2}$ may continue to be released even after the solution is saturated with respect to uranium.

A team of Canadian investigators conducted studies combining electrochemical techniques with X-ray photoelectron spectroscopy, which allowed identification of different oxides of uranium on the surface of the $\mathrm{UO}_{2}$ (Sunder et al. 1981, 1982, 1983; Shoesmith et al. 1983, 1984). Using these techniques, the Canadians were able to follow the oxidation of $\mathrm{UO}_{2}$ through various stages and determine at approximately which stage dissolution began in their experiments. Their results suggest that dissolution does not become prevalent until the surface of the $\mathrm{UO}_{2}$ has been oxidized to a composition corresponding to $\mathrm{UO}_{2.33}\left(\mathrm{U}_{3} \mathrm{O}_{7}\right)$. They have proposed that the uranyl ion is the active intermediate in the dissolution of uranium. Figure 15 summarizes the various stages of $\mathrm{UO}_{2}$ oxidation that they believe occurred under neutral and alkaline conditions in their experiments.

The results of the electrochemical/surface analysis studies discussed above suggest that spent fuel should be much more resistant to dissolution in reducing environments than in oxidizing environments, and that dissolution should be minimized under conditions where $\mathrm{UO}_{2}$ is not oxidized beyond the $\mathrm{UO}_{2} .33$ state. Also, since the uranyl ion readily complexes with a number of anions $\left(\mathrm{OH}^{-}, \mathrm{HCO}_{3}^{-}, \mathrm{CO}_{3}^{-2}, \mathrm{~F}^{-}, \mathrm{Cl}^{-}, \mathrm{SO}_{4}^{-2}, \mathrm{H}_{2} \mathrm{PO}_{4}^{-}, \mathrm{HPO}_{4}^{-2}\right.$, and $\left.\mathrm{PO}_{4}^{-3}\right)$, the dissolution of $\mathrm{UO}_{2}$ can be expected to be enhanced by the presence of these anions. 


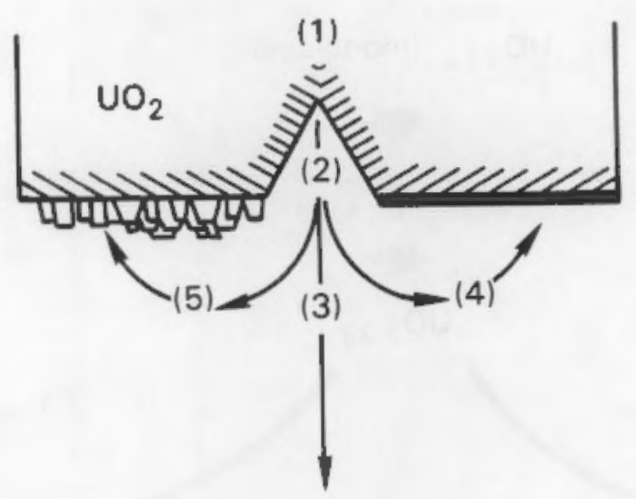

Reactions

(1) Surface Oxidation (several angstroms)

$\mathrm{UO}_{2}+\mathrm{x} / 2 \mathrm{O}_{2} \longrightarrow \mathrm{UO}_{2+x}$

$0<x \leq 1$

(2) Oxidation-Dissolution

$$
\begin{aligned}
& \mathrm{UO}_{2+\mathrm{x}}+2 \mathrm{H}^{+}+(1-x) / 2 \mathrm{O}_{2} \longrightarrow \mathrm{UO}_{2}^{+2}+\mathrm{H}_{2} \mathrm{O}, \\
& \mathrm{UO}_{2+\mathrm{x}}+\mathrm{H}^{+}+(1-x) / 2 \mathrm{O}_{2} \longrightarrow \mathrm{UO}_{2}(\mathrm{OH})^{+}, \\
& \mathrm{UO}_{2+\mathrm{x}}+\mathrm{H}_{2} \mathrm{O}+(1-x) / 2 \mathrm{O}_{2} \longrightarrow \mathrm{UO}_{2}(\mathrm{OH})_{2}^{0}
\end{aligned}
$$

$\mathrm{pH}<4$ $4 \leq \mathrm{pH} \leq 7$ $\mathrm{pH} \geq 7$

$\mathrm{pH} \leq 4$

$4 \leq \mathrm{pH} \leq 7$

$\mathrm{pH} \geq 7$

$\mathrm{pH} \leq 4$

$4 \leq \mathrm{pH} \leq 7$

$\mathrm{pH} \geq 7$

FIGURE 14. Dissolution Mechanisms for $\mathrm{UO}_{2}$ in Deionized Water (Wang 1981) 


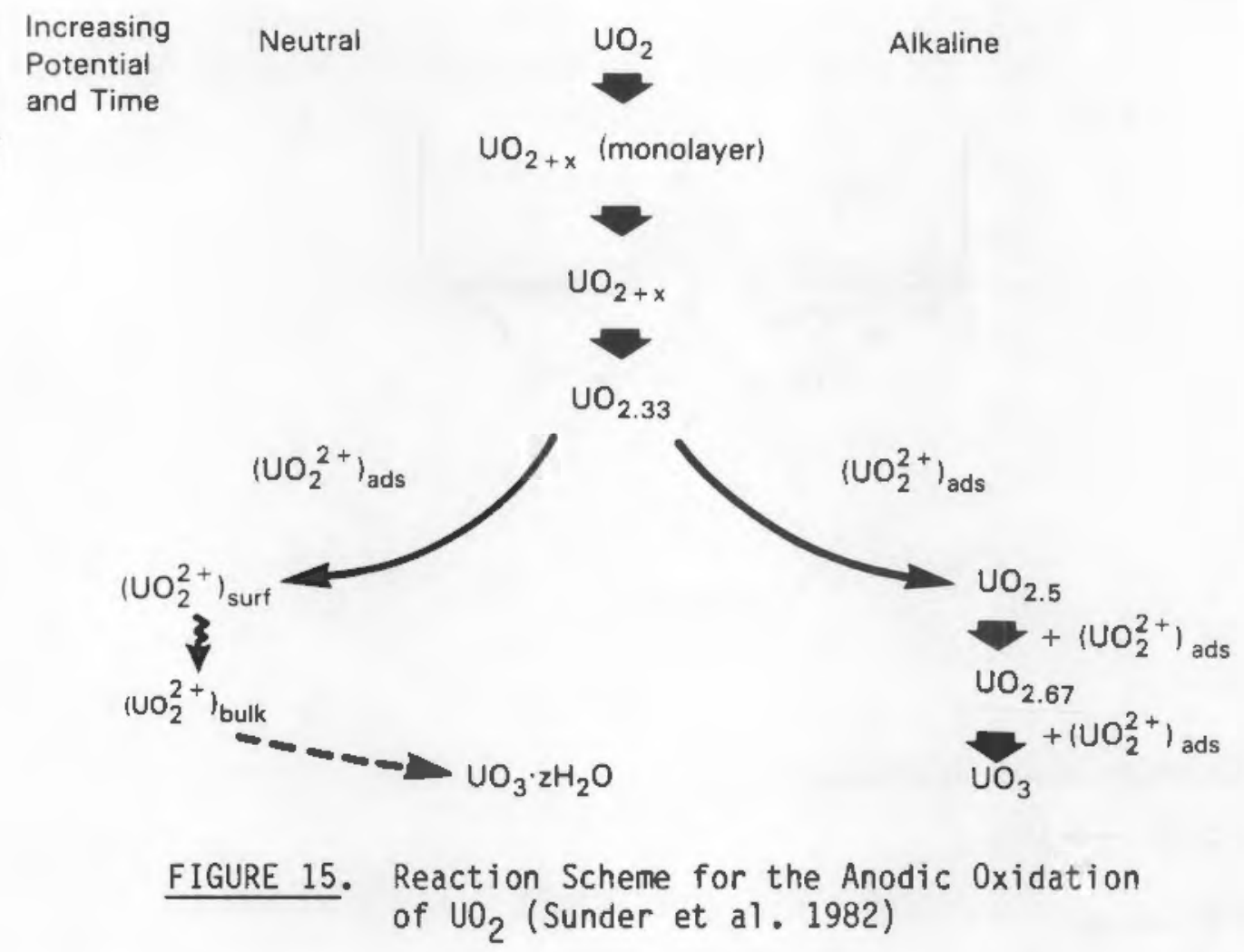

\subsection{EFFECT OF RADIOLYSIS ON RADIONUCLIDE RELEASE}

The effect of radiolysis on radionuclide release from spent fuel has been investigated from a theoretical standpoint, but very few experimental studies have been done to date. Alpha-radiolysis of water is expected to produce hydrogen peroxide $\left(\mathrm{H}_{2} \mathrm{O}_{2}\right)$ and hydrogen $\left(\mathrm{H}_{2}\right)$ within a $30 \mu \mathrm{m}$ layer surrounding the spent fuel surface (the alpha-particles are expected to penetrate the water only to this extent) (Draganic and Draganic 1971; Christensen and Bjergbakke 1982; Simonson and Kuhn 1984; Gray and Simonson 1985). Because hydrogen is relatively inert (in the absence of catalysts) at the temperatures expected under disposal conditions, and because hydrogen peroxide is a strong oxidizing agent, radiolysis is predicted to produce an oxidizing environment in the vicinity of the spent fuel surface. This oxidizing environment is predicted to enhance the dissolution of the spent fuel, which should also enhance the release of radionuclides from the spent fuel (Grenthe, Puigdomenech and Bruno 1983; Neretnieks 1984). 
Other effects of radiolysis on spent fuel dissolution have also been investigated (Christensen and Bjergbakke 1984; Christensen 1984). If gaseous nitrogen or certain organic species are present in the radiation field, the formation of nitric or organic acids could result (Rai et al. 1980; Christensen 1984). This would drop the $\mathrm{pH}$ in the vicinity of the spent fuel surface, which would increase the solubility of $\mathrm{UO}_{2}$ in the ground water. Beta-radiolysis may have a beneficial effect on the solution environment surrounding the spent fuel. Christensen and Bjergbakke (1984) have predicted that beta-radiolysis may help recombine some of the products of alpha-radiolysis, although this effect would probably be most prevalent outside the $30 \mu \mathrm{m}$ layer in which the alpha-radiolysis products are formed.

In a recent study done by the Canadians, a $\mathrm{UO}_{2}$ electrode was exposed to an alpha source at various distances to get an idea of how radiolysis would affect the oxidizing potential of the electrode (Bailey, Johnson and Shoesmith 1985). It was found that the electrode potential was unaffected until the alpha source was within about $30 \mu \mathrm{m}$ of the surface, at which time the potential jumped to a very oxidizing value. Some surface oxidation of the electrode was observed, but the extent of this was not determined. The experimentalists believed that the main reaction occurring was the decomposition of hydrogen peroxide to water and $\mathrm{O}_{2}$.

Differences between the dissolution rates of $\mathrm{UO}_{2}$ and spent fuel under similar experimental conditions have been observed in some studies (Barner et al. 1985; Myers, Apted and Mazer 1984; Schramke, Simonson and Coles 1984). Although one would expect the dissolution rate to be greater from the spent fuel due to radiolysis effects, the results have been mixed. Barner et al. (1985) observed that the total release of uranium from spent fuel in brine was over 100 times greater than the uranium released from $\mathrm{UO}_{2}$ in the same solution. Results from Myers et a1. (1984) and Schramke, Simonson and Coles (1984), however, indicate that the uranium released from simulated spent fuel in basalt ground water was almost an order magnitude greater than the release from spent fuel. Clearly radiolysis cannot be used to explain these results, because the simulated spent fuel does not have a radiation field associated with it. 


\subsection{EFFECT OF WASTE PACXAGE CONSTITUENTS ON RADIONUCLIDE RELEASE}

The effect of the presence of waste package constituents such as iron, zircaloy, and packing materials (e.g., bentonite) on radionuclide release from spent fuel is of interest because it is widely believed that these constituents will help retard the release of radionuclides from waste packages. In one of the few experimental studies that have been done in this area, Barner et al. (1985) have conducted tests on $\mathrm{UO}_{2}$ and spent fuel in brines in the presence of iron and oxidized zircaloy.

In these tests, uranium, plutonium, and technetium were all observed to precipitate in the presence of iron in brine solutions. The iron did not affect the total release of these elements, but it drastically reduced the concentrations of these elements in the brine. Cesium did not exhibit this behavior in the presence of iron. Another finding was that the presence or absence of oxidized zircaloy appeared to have no affect on the disposition of any of the radionuclides in brine.

The fact that the presence of iron caused precipitation of the actinides and technetium can be attributed to two factors: 1) the reducing characteristics of ferrous iron $\left(\mathrm{Fe}^{+2}\right)$, which reduce the radionuclides to less soluble oxidation states, and/or 2) the selective sorption of the multivalent ions onto the iron or container walls. These characteristics make iron (particularly in lower oxidation states) a desirable component of canisters and of packing materials such as bentonite. (The net effect of the iron is to retard the migration of radionuclides by dropping them out of solution.) The ferrous iron that naturally occurs in basalt is expected to have similar beneficial effects on the performance of the waste package. The iron in basalt may explain why the release of uranium from spent fuel was no greater than the release of uranium from simulated spent fuel in the presence of basalt in the Myers, Apted and Mazer (1984) and the Schramke, Simonson and Coles (1984) experiments, even though radiolysis was occurring in the case of spent fuel (i.e., the oxidants formed by radiolysis may have been reduced by the iron). The fact that the disposition of cesium is not affected by the presence of iron can be attributed to its high solubility and lack of redox behavior. 
From the oxidized zircaloy results, it can be concluded that zircaloy does not appreciably reduce the radionuclides and that the radionuclides do not adsorb to the surface of the zircaloy. Zircaloy, therefore, can not be expected to beneficially affect the performance of the waste package other than to provide physical containment of the radionuclides prior to cladding failure (i.e., rupture).

\subsection{SORPTION, PRECIPITATION, COLLOIDS, AND THE FORMATION OF ALTERATION PHASES}

Probably the most complex and least understood aspect of radionuclide release from spent fuel (and the dissolution of $\mathrm{UO}_{2}$ ) is the disposition of the radionuclides after being released from the spent fuel. Once released, the radionuclides are free to interact with waste package constituents (see Section 6.10) and the host rock. Various radionuclides have been observed to 1) adsorb to solid surfaces, 2) precipitate from solution (sometimes only on certain surfaces), 3) combine with constituents in solution or in the host rock to form thermodynamically stable phases, and 4) form colloids with other species in solution. The first three effects are generally beneficial to the performance of the spent fuel waste package, but the problem of how to quantify them so that credit can be taken for them remains unsolved. Indeed these effects may be responsible for some of the disagreement in the release rate data from different radionuclide release experiments.

"Plateout", a term used to describe the sorption or precipitation of an element onto a solid surface, has been observed in many of the radionuclide release experiments described in this report. Differences between the activities of radionuclides in filtered and unfiltered solutions have also been observed, suggesting the formation of filterable colloids or suspended precipitates containing radionuclides. Unfortunately, plateout inventory and colloidal inventory have not always been accounted for in experiments or in the reporting of results, which makes comparison between experiments difficult. In some cases, the plated out and colloidal material have been combined with the material in solution to give the total release from the waste form. In other 
cases, the amount of material accumulated on each surface and in the solution as both dissolved species and filterable species has been meticulously measured and separately reported.

Some general observations regarding the disposition of radionuclides after being released from spent fuel are listed below. (These are in addition to the observations made by Barner et al. (1985) in their study of the effects of iron and zircaloy.)

1. Uranium has been observed to plate out on container walls in a number of spent fuel release tests (see Table 2).

2. Uranium, plutonium, americium, and curium have all been observed to plate out on quartz in tuff ground water (Wilson and Oversby 1985). Technetium and cesium plated out to a much lesser extent in this solution.

3. The alteration phases coffinite $\left(\mathrm{U}\left(\mathrm{SiO}_{4}\right)_{1-x}(\mathrm{OH})_{4 x}\right)$ and weeksite and/or boltwoodite (hydrated potassium-uranium-silicate phases) have been observed to form in autoclave tests on simulated spent fuel at $300^{\circ} \mathrm{C}$ in the presence of basalt rock (Myers, Apted and Mazer 1984). Coffinite is predicted to be the most stable phase in the simulated spent fuel/basalt system, but weeksite/boltwoodite was observed in greater quantities, suggesting that it may be an intermediate phase (Myers, Apted and Mazer 1984).

The formation of stable alteration phases is a thermodynamically driven process that is summarized by the expression (Giggenbach 1981):

$$
\begin{aligned}
& \text { Initial Solution + Primary (unstable) Phases ---> } \\
& \qquad \text { Final Solution + Secondary (stable) Phases }
\end{aligned}
$$

The reactions represented by this expression may be difficult to characterize because the kinetics can be very slow and because the reactions may proceed through a series of metastable intermediates that persist for indefinite periods of time. Excellent discussions of some of the thermodynamic and kinetic considerations that are important in predicting radionuclide release 
from waste forms are given by Apted (1982) and Myers, Apted and Mazer (1984). These discussions reference a number of studies of interactions of nuclear waste with surrounding. rock and of fundamental geothermal equilibria (Garrels and Christ 1965; Helgeson 1968; Mottl and Holland 1978; Berner 1978; McCarthy et al. 1979; Seyfried and Bischoff 1979 and 1981; Giggenbach 1981; Wolery 1981; Dibble and Tiller 1981; Komarneni 1981; Freeborn et al. 1982). Radionuclide sorption and colloid formation studies were not extensively reviewed for this report. We refer the reader to the Scientific Basis for Nuclear Waste Management series (Materials Research Society symposia proceedings) as a starting point for obtaining information on the progress of this work. 



\subsection{CHARACTERISTICS OF SPENT FUEL PERTINENT TO RADIONUCLIDE RELEASE}

The characteristics of spent fuel expected to be important to the release of radionuclides from spent fuel are (Jenson 1982):

- the surface area of the spent fuel exposed to the dissolving solution

- the residence locations of the fission products and actinides and the phases that they exist in

- the grain boundary conditions of the fuel

- the surface oxidation state of the fuel.

The surface area is a function mainly of the irradiation and thermal history of the fuel. Thermal cycling and the development of steep axial and radial thermal gradients during irradiation cause the fuel to crack, which generates more surface area.

The importance of the residence locations of the radionuclides and the phases that they exist in was discussed in Section 6.1. Radionuclides that form compounds (primarily oxides) that are soluble in the $\mathrm{UO}_{2}$ matrix generally remain in the $\mathrm{UO}_{2}$ matrix during irradiation. Nuclides that are not soluble in the $\mathrm{UO}_{2}$ matrix tend to migrate down the temperature gradient to the fuel periphery or grain boundaries, making them more accessible to solutions. Exceptions to this have been observed, however (see some of the references in Appendix B).

The grain boundary conditions of the fuel are important because the grain boundaries may contain significant inventories of radionuclides that are not soluble in the $\mathrm{UO}_{2}$ matrix. If the grains are tightly bound together, release of the radionuclides from the grain boundaries may be restricted; but if the grains are loosely bound and there is sufficient space between them to allow solution access, release may occur quite rapidiy.

The oxidation state of the surface of the fuel is expected to be important to radionuclide release because $U_{2}$ dissolution is believed to proceed by a mechanism that involves oxidation of the $\mathrm{UO}_{2}$ prior to dissolution (see Section 6.8). The presence of an oxidized surface layer on the fuel may speed up 
dissolution under oxidizing conditions because the fuel will already be oxidized to some extent before contacting the solution. Under reducing conditions, the oxidized surface layer may serve to passivate the surface of the fuel, thereby hindering release. Oxidation of the surface of the fuel can occur during pool storage or dry storage if the fuel cladding has been ruptured.

As part of this literature survey, a great deal of published material on the characterization of spent fuel has been compiled for the informal library of the Waste Package Program (WPP) modeling task at PNL. An annotated bibliography of these materials is given in Appendix $B$ for the reader who wants more information concerning the characterization of spent fuel. 


\subsection{STATUS OF MODELING OF RADIONUCLIDE RELEASE FROM SPENT FUEL}

Because so many aspects of radionuclide release from spent fuel are not yet fully understood, modeling of radionuclide release from spent fuel has usually been discussed in general terms rather than mathematical terms $(\mathrm{e} . \mathrm{g}$. , Liebetrau and Apted 1985). Stochastic models of release from spent fuel for use in performance assessment studies have been proposed (Goodwin, Johnson and Wuschke 1983; Goodwin, Lemire and Johnson 1982), but because these models are parametric in nature, they do not properly describe the mechanistic processes of release.

Goodwin (1984), Allard (1984a and b), Skytte-Jensen (1984), and Johnson, Garisto and Stroes-Gascoyne (1985) have all discussed some of the complexities of modeling radionuclide release from spent fuel. In an early modeling attempt, Kuhn (1981) assumed (for computational purposes) that the release of uranium from spent fuel was controlled by uranium solubility and that all radionuclides were released congruently with uranium. Many investigators now believe that oxidation of the $\mathrm{UO}_{2}$ matrix (as a precursor to dissolution) is the controlling process for uranium release, and it is widely recognized that the fission products ${ }^{134} C_{s},{ }^{137} \mathrm{Cs}$ and ${ }^{129} \mathrm{I}$ tend to release more rapidly from spent fuel than other radionuclides ( ${ }^{99} \mathrm{Tc}$ may also be a rapidly releasing radionuclide). Long-term release, however, may still be controlled by thermodynamics if precipitates or stable alteration phases containing radionuclides form in the system.

Johnson and Joling (1984) have used a probability distribution function to predict the instant release fraction of cesium and iodine from the fuelcladding gap and grain boundaries of Canadian (CANDU) fuel. Their work suggests that the inventory of radionuclides at the grain boundaries is far more significant than the inventory in the gap. This point is illustrated graphically in Figure 16 (Johnson, Garisto and Stroes-Gascoyne 1985), which shows the release rate of radionuclides from the gap, grain boundaries, and grains of spent fuel as a function of time. It is assumed here that the $\mathrm{UO}_{2}$ grains dissolve at a constant rate and that the radionuclides contained in the grains are released congruently from them. A major uncertainty that needs to be 


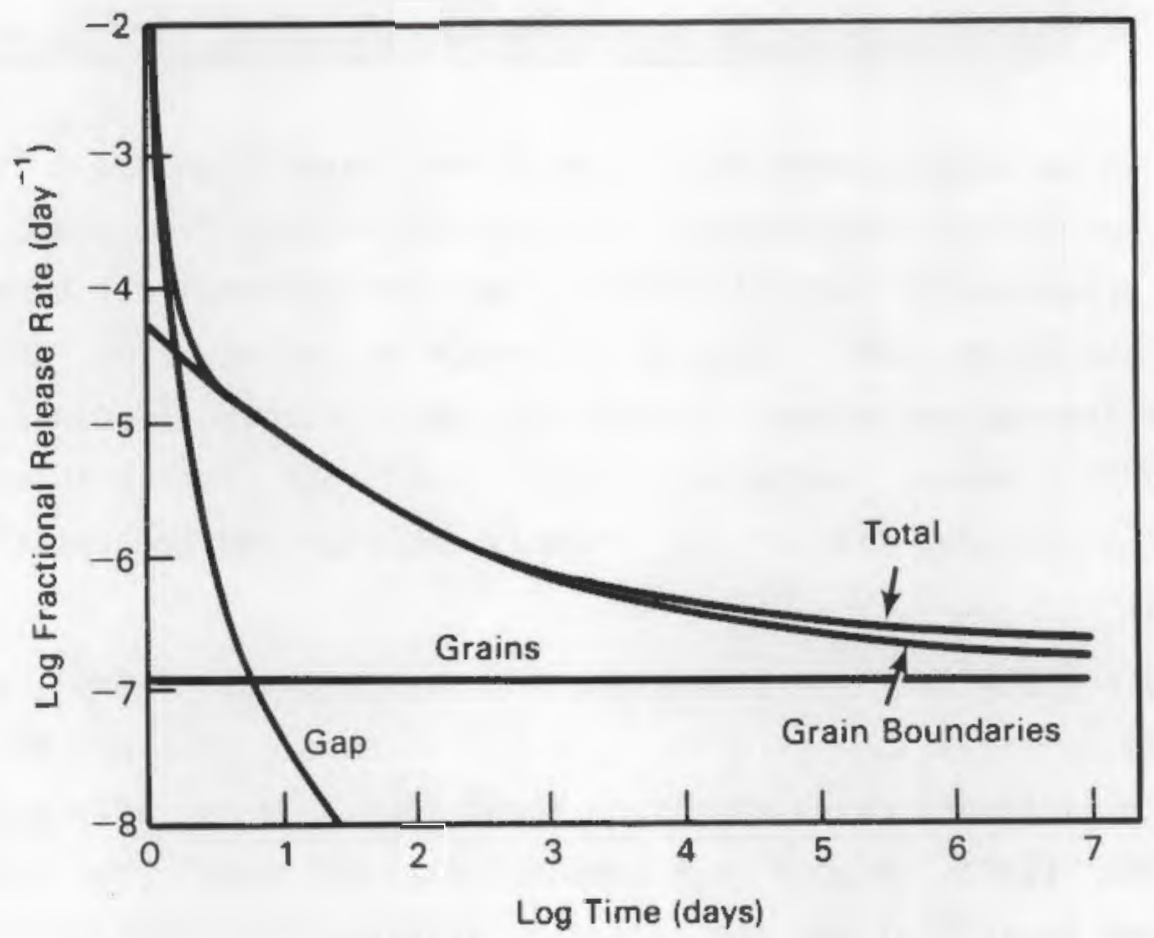

FIGURE 16. Radionuclide Release from $\mathrm{UO}_{2}$ Fuel in Water, Oxidizing Conditions (Johnson, Garisto and Stroes-Gascoyne 1985)

investigated is how quickly the radionuclides at the grain boundaries will become exposed to solution so that the soluble constituents can be dissolved.

Modeling of the release of radionuclides from spent fuel grains (i.e., the $\mathrm{UO}_{2}$ matrix) is still in the conceptual stage. Since spent fuel is primarily $\mathrm{UO}_{2}$ and hydrates slowly if not oxidized, the degradation of spent fuel is expected to be essentially the rate of oxidation of $\mathrm{U0}_{2}$. The resulting oxidized matrix hydrates and releases its radionuclides to varying extents. It appears that most radionuclides contained in spent fuel, including uranium, release roughly in proportion to the square root of time. This behavior is probably a result of release from the grain boundaries of the fuel (see Figure 16). The effect of an increased uranium concentration in the solution on the degradation rate of spent fuel is not known.

The effects of alpha-radiolysis on the release of radionuclides from spent fuel are not clearly understood. Some investigators believe that alpharadiolysis can promote the oxidation of spent fuel through the radiolytic 
production of $\mathrm{H}_{2} \mathrm{O}_{2}$ and other oxidizing species in the solution adjacent to the surface of the spent fuel. Under conditions of low, buffered Eh, however, the radiolytically produced oxidants may be quickly reduced to species that do not affect the spent fuel. Even if radiolysis is capable of generating a locally oxidizing environment near the surface of spent fuel in an overall reducing environment, many of the radionuclides that are released as a result of being oxidized to more soluble valence states might revert to lower valence states and precipitate once they are transported out of the oxidizing environment near the surface.

The formation and degradation of alteration phases in the waste package environment is poorly understood. The rates of formation of these phases, the intermediates involved in this process, and the characteristics of the phases need to be studied in more detail before alteration phases can be accounted for in models. 


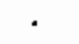

- 


\subsection{CONCLUSIONS REGARDING MODELING OF RADIONUCLIDE RELEASE FROM SPENT FUEL}

Based on what has been learned in studies of radionuclide release from spent fuel and $\mathrm{UO}_{2}$, a complete model for the release of radionuclides from spent fuel should include:

- An instant release submodel describing the rate of release of radionuclides that have accumulated in the fuel-cladding gap and at the grain boundaries of the fuel.

- A kinetic submodel describing the rate of degradation (i.e., oxidation and dissolution) of the spent fuel matrix, which describes the rate at which many radionuclides become unbound from the spent fuel and available for transport.

- A post-release submodel, which describes the accumulation of radionuclides in solution, the formation of precipitates, colloids, and alteration phases, and the constraints on these processes.

- A mass transfer submodel, which describes the transport of the radionuclides away from the spent fuel according to the concentration of radionuclides in solution. 


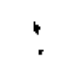

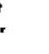




\subsection{REFERENCES}

Allard, B. 1982. "Solubilities of Actinides in Neutral or Basic Solutions." Actinides in Perspective. Permagon Press, Oxford.

Allard, B. 1983. Actinide Solution Equilibria and Solubilities in Geologic Systems. SKBF-KBS-83-35, Swedish Nuclear Fuel Supply Company/Division KBS, Stockholm, Sweden.

Allard, B. 1984a. "Actinide and Technetium Solubility Limitations in Groundwaters of Crystalline Rocks." Scientific Basis for Nuclear Waste Management VII. Elsevier Science Publishing Co., New York, NY, p. 219-226.

Allard, B. 1984b. "The Geochemistry of High-Level Waste Disposal in Granitic Rock." The Geochemistry of High-Level Waste Disposal in Granitic Rock. AECL-8361, Whiteshell Nuclear Research Establishment, Pinawa, Manitoba, Canada.

Apted, M. J. 1982. "Overview of Hydrothermal Testing of Waste Package Barrier Materials at the Basalt Waste Isolation Project" in Workshop on the Leaching Mechanisms of Nuclear Waste Forms, May 19-21, 1982. Summary Report. PNL-4382, Pacific Northwest Laboratory, Richland, WA.

Apted, M. J. and J. Myers. 1982. Comparison of the Hydrothermal Stability of Simulated Spent Fuel and Borosilicate Glass in a Basaltic Environment. RHOBW-ST--38-P, Rockwell Hanford Operations, Richland, WA.

Baes, C. F. and R. F. Mesmer. 1976. The Hydrolysis of Cations. John Wiley and Sons, New York, NY.

Bailey, M. G., L. H. Johnson, and D. W. Shoesmith. 1985. "Effects of AlphaRadiolysis of Water on the Corrosion of $\mathrm{UO}_{2} \cdot$ " Corrosion Science, Vol. 25, No. 4, p. 233-238.

Barner, J. 0., W. J. Gray, G. L. McVay, and J. W. Shade. 1986. Interactive Leach Tests of $\mathrm{UO}_{2}$ and Spent Fuel with Waste Package Components in Salt Brine. PNL-4898-SRP, Pacific Northwest Laboratory, Richland, WA.

Bazan, F., J. Rego, R. Failor, and D. Coles. 1984. Leaching Studies Using PNL 76-68 Glass Beads and $\mathrm{UO}_{2}$ Rods with Umtanum Basalt and Nugget Sandstone. UCID-20013, Lawrence Livermore National Laboratory, Livermore, CA.

Berner, R. A. 1978. "Rate Control of Mineral Dissolution Under Earth Surface Conditions." Amer. J. of Sci., Vol. 278, p. 1235-1252.

Bird, G. W. 1980. "Geochemistry of Radioactive Waste Disposal." Geoscience Canada. Vol. 6, No. 4, p. 199-204. 
Bradley, D. J., G. L. McVay, and D. G. Coles, 1980. Leach Test Methodology for the Waste/Rock Interactions Technology Program. PNL-3326, Pacific Northwest Laboratory, Richland, WA.

Bryant, E. A. 1979. Fission Product Release. LA-7797-PR, Uanuary 1 March 31, Los Alamos National Laboratory, Los Alamos, NM.

Burns, Ko I. , C. J. Moore, and D. G. Boase. 1982. Release of ${ }^{134} \mathrm{Cs},{ }^{137} \mathrm{Cs}$, and ${ }^{129}$ I from the Fuel/Sheath Gap of CANDU Irradiated Fuel. Presented at Canadian Nuctear Society International Conference on Radioactive Waste Management, Winnipeg, Canada.

Christensen, H. 1984. Formation of Nitric and Organic Acids by the Irradiation of Ground Water in a Spent Fuel Repository. KBS-TR-84-12, Swedish Nuclear Fuel and Waste Management Company, Stockholm, Sweden.

Christensen, H. and E. Bjergbakke. 1982. Radiolysis of Ground Water from Spent Fuel. KBS-TR-82-18, Swedish Nuclear Fuel and Waste Management Company, Stockholm, Sweden.

Christensen, H. and E. Bjergbakke. 1984. Effect of Beta-Radiolysis on the Products from Alpha-Radiolysis of Ground Water. KBS-84-03, Swedish Nuclear Fuel Supply Company/Division KBS, Stockholm, Sweden.

Cleveland, J. M. 1979. The Chemistry of Plutonium. American Nuclear Society, LaGrange Park, IL.

Coles, D. G. 1981. "A Continous-Flow Leach Testing Method for Various Nuclear Waste Forms." Nuclear and Chemical Waste Management, Vol. 2, No. 4, p. 245-252.

Croff, A. G. 1980. ORIGEN-2 - A Revised and Updated Version of the ORNL Isotope Generation and Oepletion Code. ORNL-5621, Oak Ridge National Laboratory, Oak Ridge, TN.

Deve1 l, L. and R. Hesbol. 1978. Leachable Gap Activities. KBS-TR-109, Studsvik Energiteknix $A B$, Nykoping, Sweden.

Dibble, W. E. and W. A. Tiller. 1981. "Non-Equilibrium Water/Rock Interactions-I. Model for Interface-Controlled Reactions." Geochimica et Cosmochimica Acta, Vol. 45, p. 79-92.

Dosch, R. G. 1981. Solubility and Sorption Characteristics of Uranium(VI) Associated with Rock Samples and Brines/Groundwaters from WIPP and NTS. SAND-80-1595, Sandia NationaT Laboratory, ATbuquerque, NM.

Draganic, I. G. and Z. D. Draganic. 1971. The Radiation Chemistry of Water. Academic Press, New York, NY.

Duffy, C. J. and A. E. Ogard. 1982. Uranite Immobilization and Nuclear Waste. LA-9199-MS, Los Alamos National Laboratory, Los ATamos, NM. 
Eklund, U, B. and R. Forsyth. 1978. Leaching of Irradiated U0 2 Fuel. KBS-TR-70, Aktiebolaget Atomenergi, Sweden.

Felmy, A. R., D. C. Girvin, and E. A. Jenne. 1984. MINTEQ: A Computer Program for Calculating Aqueous Geochemical Equilibria, EPA-600/3-84-032 (NTIS PB84-157148), Prepared for the U.S. Environmental Protection Agency (Athens, Georgia) by Battelle, Pacific Northwest Laboratories, Richland, WA.

Forsyth, R. S. 1982. KBS U0, Leaching Program Status Report." Studsvik Energiteknik $A B, N F(P)-82 / 49$, Nykoping, Sweden.

Forsyth, R. 1983, KBS U0, Leaching Program. Summary Report, 1983-02-01. SKBF-KBS-TR-83-26, Studsvik Energiteknik AB, Nykoping, Sweden.

Forsyth, R. S., K. Svanberg, and L. Werme. 1984. The Corrosion of Spent U0, Fuel in Synthetic Groundwater. Studsvik Energiteknik AB, Nykoping, Sweden.

Freeborn, W. P., et al. 1982. Hydrothermal Interactions Between Calcine, Glass, Spent Fuel, and Ceramic Waste Forms with Representative Shale Repository Rocks. ONWI-306, Office of Nuclear Waste Isolation, Columbus, $\mathrm{OH}$.

Garisto, F. and N. C. Garisto. 1985. "The U0, Solubility Function for the Assessment of Used Nuclear Fuel Disposal. Nuclear Science and Engineering, $90: 1$, p. $103-110$.

Garrels, R. M. and C. L. Christ. 1965. Solutions, Minerals, and Equilibria. Freeman, Cooper, and Co., San Francisco, CA.

Gayer, K. H. and H. Leider. 1955. "The Solubility of Uranium Trioxide, $\mathrm{UO}_{3}{ }^{\circ} \mathrm{H}_{2} \mathrm{O}$, in Solutions of Sodium Hydroxide and Perchloric Acid at $25^{\circ} \mathrm{C}$." J. of Amer. Chem. Soc., Vol. 77, No. 6, p. 1448-1450.

Gayer, K. H. and H. Leider. 1957. "The Solubility of Uranium(IV) Hydroxide in Solutions of Sodium Hydroxide and Perchloric Acid at $25^{\circ} \mathrm{C}$." Canadian J. of Chem., Vol. 35, No. 1, p. 5-7.

Giggenbach, W. F. 1981. "Geothermal Mineral Equilibria." Geochimica et Cosmochimica Acta. Vol. 45, p. 393-410.

Goodwin, B. W. 1980. Maximum Total Uranium Solubility Under Conditions Expected in a Nuclear Waste Vault. TR-29, Whiteshell Nuclear Research Establishment, Pinawa, Manitoba, Canada.

Goodwin, B. W. 1984. "The Validity of Long-Term Waste-Form Release Models." Geochemistry of High-Level Waste 0isposal in Granitic Rocks. AECL-8361, Whiteshel1 Nuclear Research Establishment, Pinawa, Manitoba, Canada.

Goodwin, B. W., L. H. Johnson, and D. M. Wuschke. 1983. Radionuclide Source Terms for Irradiated $\mathrm{UO}_{2}$ Fuel. AECL-7352, Whiteshell Nuclear Research Establishment, Pinawa, Manitoba, Canada. 
Goodwin, B. W., R. J. Lemire, and L. H. Johnson. 1982. "A Stochastic Model for the Dissolution of Irradiated $\mathrm{UO}_{2}$ Fuel." Proceedings of the International Conference on Radioactive Waste Management, Sept. 1983, Canadian Nuclear Society, Toronto. p. 298-304. Winnipeg, Manitoba, Canada.

Grandstaff, D. E. 1976. "A Kinetic Study of the Dissolution of Uraninite." Economic Geology, Vol. 71, No. 8, p. 1493-1506.

Grandstaff, D. E., G. L. Mckeon, E. L. Moore, and G. C. Ulmer. 1983. Reactions in the System Basalt/Simulated Spent Fuel/Water. RHO-BW-SA-31-7P, Rockwell Hanford Operations, Richland, WA.

Gray, W. J., G. L. McVay, J. O. Barner, J. W. Shade, and R. W. Cote. 1983. Evaluation of a Spent Fuel as a Waste Form in a Salt Repository. PNL-SA11770, Pacific Northwest Laboratory, Richland, WA.

Gray, W. J. and G. L. McVay. 1984. "Comparison of Spent Fuel and U0, Release in Salt Brines." Proceedings of the Third Spent Fuel Workshop, March 1984. KBS-83-76, Studsvi Energiteknik AB, Nykoping, Sweden.

Gray, W. J., and G. L. McVay. 1986. FY-1984 Annual Report: Spent Fuel and $\mathrm{UO}_{2}$ Source Term Evaluation Results. PNL-5650, Pacific Northwest Laboratory. Richland, WA.

Gray, W. J. and S. A. Simonson. 1985. "Gamma and Alpha Radiolysis of Brines." Scientific Basis for Nuclear Waste Management VIII. Materials Research Society, Pittsburgh, PA, p. 623-630.

Grenthe, I., I. Puigdomenech, and J. Bruno. 1983. The Possible Effects of Alfa and Beta Radiolysis on the Matrix Dissolution of Spent Nuclear FueT. KBS-83-02, Swedish Nuclear Fuel Supply Company/Division KBS, StockhoTm, Sweden.

Gromov, V. 1981. "Dissolution of Uranium Oxides in the Gamma Radiation Field." Radiation Physical Chemistry, Vol. 18, №. 1-2, pp. 135-146.

Helgeson, H. C. 1968. "Evaluation of Irreversible Reactions in Geochemical Processes Involving Minerals and Aqueous Solutions - I. Thermodynamic Relations." Geochimica et Cosmochimica Acta., Vol. 32, No. 8, p. 853-877.

Hespe, E. 0., editor. 1971. "Leach Testing of Immobilized Radioactive Waste Solids, A Proposal for a Standard Method." Atomic Energy Review, Vol. 9, No. 1, p. 195-207.

Hiskey, J. B. 1979. "Kinetics of Uranium Oioxide Dissolution in Ammonium Carbonate." Iransactions of the Institution of Mining and Metallurgy, Vol. 88, p. C 145-152.

Hiskey, J. B. 1980. "Hydrogen Peroxide Leaching of Uranium in Carbonate Solutions." Transactions of the Institution of Mining and Metallurgy, Vol. 89, p. 145-152. 
Holland, H. D. and L. H. Brush. 1978. "Uranium Oxides in Ores and Spent Fuels." Proceedings of the Conference on High-Level Radioactive Solid Waste Forms, December 1978, Denver, CO, NUREG/CP 0005 (NTIS), Nuclear Regulatory Comission, Washington, DC, p. 597-615.

INTERA Environmental Consultants, Inc. 1983. EQ3/EQ6: A Geochemical Speciation and Reaction Path Code Package Suitable for Nuclear Waste Performance Assessment. ONWI-472. Prepared for Battelle Memorial Institute, office of Nuclear Waste Isolation, Columbus, $\mathrm{OH}$.

Jenson, E, D. 1982. Characteristics of LWR Spent Fuel with Respect to Properties Pertinent to Leaching and Dissolution. HEDL-7207, Hanford Engineering Development Laboratory, Richland, WA.

Johnson, L. H. 1982. The Dissolution of Irradiated U0, Fuel in Groundwater. $\mathrm{AECL}-6837$, Whiteshe11 Nuclear Research Establishment, Pinawa, Manitoba, Canada.

Johnson, L. H., K. I. Burns, H. Joling, and C. J. Moore. 1981. The Oissolution of Irradiated $U_{2}$ Fuel Under Hydrothermal 0xidizing Conditions. TR-128, Whiteshell Nuclear Research Establishment, Pinawa, Manitaba, Canada.

Johnson, L. H., K. I. Burns, H. H. Joling, and C. J. Moore. 1983. Leaching of $137 \mathrm{Cs}, 134 \mathrm{Cs}$, and $129 \mathrm{I}$ from Irradiated $\mathrm{UO}_{2}$ Fuel." Nuclear Technology, Vol. 63 , p. $470-475$.

Johnson, L. H., N. C. Garisto, and S. Stroes-Gascoyne. 1985. "Used Fuel Dissolution Studies in Canada," In Proc. of Waste Management '85, March 22-24, 1985, Tucson, AZ, Ed: Roy G. Post, p. 479-482.

Johnson, L. H. and H. H. Joling. 1982. "The Dissolution of Irradiated Fuel Under Hydrothermal Conditions." Scientific Basis for Nuclear Waste Management, Elsevier Science Publishing Co., New York, NY, p. 321-327.

Johnson, L. H. and H. H. Joling. 1984. Fission Product Leaching from Used CANDU Fuel: An Estimate of Fuel-Sheath Gap and Grain Boundary Inventories and Probable Releases after Disposal. TR-280, Whiteshell Nuclear Research Establishment, Pinawa, Manitoba, Canada.

Johnson, L. H., D. W. Shoesmith, G. E. Lunansky, M. G. Bailey, and P. R. Tremaine. 1982. "Mechanisms of Leaching and Dissolution of $\mathrm{UO}_{2}$ Fuel." Nuclear Technology, Vol. 56, p. 238-253.

Johnson, L. H., S. Stroes-Gascoyne, J. 0. Chen, M. E. Attas, 0. M. Sellinger, and $H$. G. Delaney ${ }_{37}$ 1984. "The Relationship Between Fuel Element Power and the Leaching of ${ }^{37} \mathrm{Cs}$ and ${ }^{129}$ I from Irradiated $\mathrm{UO}_{2}$ Fuel." Proceedings of the Topical Meeting on Fission Product Behavior and Source Term Research, July 15-19, 1984. Snowbird, UT, p. 15-1 to 15-12. 
Katayama, Y. B. 1976. Leaching of Irradiated LWR Fuel Pellets in Deionized and Typical Ground Water. BNWL-2057, Pacific Northwest Laboratory, Richland, WA.

Katayama, Y. B. 1979. Spent LWR Fuel Leach Tests. PNL-2982, Pacific Northwest Laboratory, Richland, WA, P. 323-334.

Katayama, Y. B. and D. J. Bradley. 1980. "Long-Term Leaching of Irradiated Spent Fuel." Scientific Basis for Nuclear Waste Management, Vol. 2, Plenum Press, New York, NY, p. 323-334.

Katayama, Y. B., D. J. Bradley, and C. 0. Harvey. 1980a. Status Report on LWR Spent Fuel IAEA Leach Tests. (March) PNL-3173, Pacific Northwest Laboratory, Richland, WA.

Katayama, Y. B., D. J. Bradley, and C. 0. Harvey, 1980b. Status Report on LWR Spent Fuel Leach Tests. (November) PNL-3473, Pacific Northwest Laboratory, Richland, WA.

Katayama, Y. B. and J. E. Mendel. 1977. Leaching of Irradiated LWR Fuel Pellets in Deionized Water, Sea Brine, and Typical Ground Water. Presented at American Nuclear Society Meeting, San Francisco, CA, November-December, 1977.

Kharaka Y. K. and I. Barnes. 1973. "SOLMNEQ--Solution Mineral Equilibrium Computations," U.S. Geological Survey Comp. Contr. PB-215-899.

Komarneni, S. 1981. "Hydrothermal Stability of $\mathrm{\beta}-\mathrm{Cs}_{2} \mathrm{U}_{2} \mathrm{O}_{7}$ and $\mathrm{SrZrO}_{3}$ in Fluids." J. of Inorg. and Nucl. Chem., Vol. 43, No. 11, p. 2833-2837.

Krupka, K. M., E. A. Jenne, and W. J. Deutsch. 1983. Validation of the WATEQ4 Geochemical Model for Uranium. PNL-4333, Pacific Northwest Laboratory, Richland, WA.

Kuhn, W. L. 1981. "Development of a Source Term for Radionuclide Release from Spent Fuel in a Basalt Repository." Nuclear and Chemical Waste Management, Vol. 2, p. 253-257.

Langmuir, D. 1978. "Uranium Solution-Mineral Equilibria at Low Temperatures with Applications to Sedimentary 0re Deposits." Geochimica et Cosmochimica Acta, Vol. 42, p. 547-569.

Langmuir, D. and J. S. Herman. 1980. "The Mobility of Thorium in NaturaT Waters at Low Temperatures." Geochimica Cosmochimica Acta, Vol. 44, p. 1753-1766.

Lemire, R. J. 1984. An Assessment of the Thermodynamic Behavior of Neptunium in Water and Model Groundwaters from 25 to $150^{\circ} \mathrm{C}$. AECL-7817, Whiteshell Nuclear Research Establishment, Pinawa, Manitoba, Canada. 
Lemire, R. J. and P. R. Tremaine. 1980. "Uranium and Plutonium Equilibria in Aqueous Solutions to $200^{\circ} \mathrm{C} . " \mathrm{~J}$. of Chem. Engineering Data, Vol. 25, No. 4, P. $361-370$.

Liebetrau, A. M. and M. J. Apted. 1985. "A Generalized Waste Package Containment Model." In Proc. of Waste Management '85, March 22-24, 1985, Tucson, AZ. Ed: Roy G. Post.

Lorenz, R. A., J. L. Collins, A. P. Malinavskas, et al. 1980. Fission Product Release from Highly Irradiated LWR Fuel. NUREG-CR-0722, Nuclear Regulatory Commission, Washington, DC.

McCarthy, G. J., W. B. White, S. Komarneni, B. E. Scheetz, W. P. Freeborn, and D. K. Smith. 1979. Hydrothermal Stability of Spent Fuel and High-Level Waste Ceramics in the Geologic Repository Environment. Pennsylvania State University. From International Symposium on Ceramics in Nuclear Waste Management, Apri1 30, 1979, Cincinnati, OH.

Mckeon, G. L., G. C. Ulmer, and D. E. Grandstaff. 1982. Results of Hydrothermal Reactions in the System Simulated Spent Fuel/Groundwater/Basalt at $200^{\circ}$ and $300^{\circ} \mathrm{C}$ and 300 Bars. RHO-BW-SA-317P, Rockwell Hanford Operations, Richland, WA.

McKeon, G. L., G. C. Ulmer, and D. E. Grandstaff. 1984. Hydrothermal Reactions in the System Basalt/Simulated Spent Fuel/Groundwater at $100^{\circ} \mathrm{C}$ and $30 \mathrm{MPa}$ Pressure. SD-BWI-TI-238, Rockwel1 Hanford Operations, Richland, WA.

McVay, G. L., D. J. Bradley, and J. F. Kircher. 1981. Elemental Release from Glass and Spent Fue1. ONWI-275, Office of Nuclear Waste Isolation, Columbus, $\mathrm{OH}$.

Mende1, J. E., editor. 1980. Materials Characterization Center Workshop on Leaching of Radioactive Waste Forms Summary Report. PNL-3318, Pacific Northwest Laboratory, Richland, WA.

Mendel, J. E. 1982. "The Measurement of Leach Rates: A Review." Nuclear and Chemical Waste Management, Vol. 3, p. 117-123.

Mendel, J. E. 1984a. Test Methods Submitted for Nuclear Waste Materials Handbook. PNL-3990, Pacific Northwest Laboratory, Richland, WA.

Mende1, J. E. 1984b. Nuclear Waste Materials Handbook - Test Methods. PNL-D0E/TIC-11400, Pacific Northwest Laboratory, Richland, WA.

Mitchell, A. D., J. H. Goode, and V. C. A. Vaughen. 1981. Leaching of Irradiated Light-Water-Reactor Fuel in a Simulated Post Accident Environment. ORNL/TM-7546, Oak Ridge National Laboratory, Oak Ridge, TN. 
Mottl, M. J. and H. D. Holland. 1978. "Chemical Exchange During Hydrothermal Alteration of Basalt by Sea Water - I. Experimental Results for Major and Minor Components of Sea Water." Geochimica et Cosmochimica Acta, Vol. 42, p. 1103-1115.

Myers, J., M. J. Apted, and J. J. Mazer. 1984. Hydrothermal Reaction of Simulated Waste Forms with Basalt Under Conditions Expected in a Nuclear Waste Repository in Basalt. RHO-BH-ST-59-P, Rockwell Hanford Operations, Richland, WA.

Neretnieks, I. 1984. "The Impact of Alpha-Radiolysis on the Release of Radionuclides from Spent Fuel in a Geologic Repository." Scientific Basis for Nuclear Haste Management VII. Elsevier Science Publishing Co., New York, NY, p. $1009-1022$.

Nicol, M. J. and C. R. S. Needes. 1975. "The Anodic Dissolution of Uranium Dioxide-I. In Perchlorate Solutions." Electrochim. Acta, Vol. 20, p. 585-589.

Nicol, M. J. and C. R. S. Needes. 1977. "The Anodic Dissolution of Uranium Dioxide-II. In Carbonate Solutions." Electrochim. Acta., Vol. 22, P. 1381-1384.

Norris, A. E. 1978. Fission Product Release, October 1 -December 31, 1978. LA-7682-PR, Los Alamos National Laboratory, Los A7amos, NM.

Norris, A. E. 1979a. Fission Product Release, April 1 - June 30, 1979. LA-7969-PR, Los Alamos National Laboratory, Los Alamos, NM.

Norris, A. E. 1979b. Fission Product Release, July 1 - September 30, 1979. LA-8149-PR, Los Alamos National Laboratory, Los Alamos, NM.

Norris, A. E. 1979c. Fission Product Release, October 1 - December 31, 1979. LA-8272-PR, Los Alamos National Laboratory, Los A1amos, NM.

Norris, A. E. 1979d. Fission Product Release Status Report Concerning Empirical Measurements of Fission Product Release from Nuclear Reactor Spent Fuel. ONWI/sub/79/E511-01200-11, Los Alamos National Laboratory, Los Al amos, NM.

Norris, A. E. 1980a. Fission Product Release, January l - March 31, 1980. LA-8389-PR, Los A1 amos National Laboratory, Los Alamos, NM.

Norris, A. E. 1980b. Fission Product Release, Apri1 1 - June 30, 1980. LA-8539-PR, Los Alamos National Laboratory, Los Alamos, NM.

Norris, A. E. 1980C. Fission Product Release, July 1 -September 30, 1980. LA-8699-PR, Los Alamos National Laboratory, Los Alamos, NM.

Notley, M. J. F. 1979. "ELESIM: A Computer Code for Predicting the Performance of Nuclear Fuel Elements." Nuclear Technology, Vol. 44, p. 445-450. 
Ogard, A., G. Bentley, E. Bryant, C. Duffy, J. Grisham, E. Norris, C. Orth, and K. Thomas. 1981. "Are Solubility Limits of Importance to Leaching?"

Scientific Basis for Nuclear Waste Management, Vol. 3, Plenum Publishing Co., New York, NY, D. 331-337.

Ogard, A. E. and E. A. Bryant. 1982. "The Misused and Misleading IAEA Leach Test." Nuclear and Chemical Waste Management, Vol. 3, p. 79-81.

Ogard, A. E. and C. J. Duffy. 1981. Eh and Fission Product Solubilities: Two Factors in the Leaching of $\mathrm{U0}_{2}$. LA-UR-80-3468, LoS ATamos National Laboratory, Los ATamos, NM.

011 ila, K. 1985. Dissolution Experiments of Unirradiated Uranium Dioxide Pellets. YJT-85-02, Technical Research Center of Finland, Finland.

Parkhaeva, T. N. and V. V. Gromov. 1975. "Dissolution of 0xides of Uranium in Sodium Carbonate Solutions." Soviet Radiochemistry, Vol. 17, No. 2, p. 173-175.

Parkhurst, D. L., D. C. Thorstenson, and L. N. Plummer, 1980. "PHREEQE--A Computer Program for Geochemical Calculations," U.S. Geol. Surv. WaterResour. Invet. 89-96, NTIS PB 81-167801.

Paquette, J. and R. J. Lemire. 1981. "A Description of the Chemistry of Aqueous Solutions of Uranium and Plutonium to $200^{\circ} \mathrm{C}$ Using Potential-pH Diagrams." Nuclear Science and Engineering, Vol. 79, p. 26-45.

Pearson, R. L. and M. E. Wadsworth. 1958. "A Kinetic Study of the Dissolution of $\mathrm{UO}_{2}$ in Carbonate Solution." Trans. Met. SoC. AIME, Vol. 212, p. 294-300.

Peehs, Jung, Schlemmer, and Kaspar. 1980. Long-Term Storage Behaviour of Spent LWR Fuel. Presented at the PATRAM Conference, Berlin, Germany.

Peehs, M., G. Kaspar, and K. H. Neeb. 1983. "Cs and I Release Source Terms from Irradiated LWR Fuel." J. of Nucl. Mater., Vol. 119, p. 284-290.

Peehs, M., W. Petri, H. P. Fuchs, and F. Schlemmer. 1978. "Behavior of Spent LWR Fuel Assemblies." Proceedings of the NEA Seminar on the Storage of Spent Fuel Elements. Organisation for Economic Co-operation and Development, Nuclear Energy Agency, Paris, France, p. 223-233.

Pourbaix, M. 1966. Atlas of Electrochemical Equilibria in Aqueous Solutions. Pergamon Press, oxford.

Rai, D. and R. J. Serne. 1977. "Plutonium Activities in Soil Solutions and the Stability and Formation of Selected Plutonium Materials." J. Environ. Qual, Vol. 6, p. 89-95. 
Rai, D., R. G. Strickert, and J. L. Ryan. 1980. "Alpha Radiation Induced Production of $\mathrm{HNO}_{3}$ During Dissolution of $\mathrm{Pu}$ Compounds (1)." Inorganic Nuclear Chemistry Letters, Vol. 16, p. 551-555.

Rees, J. H. 1985. "The Theoretical Derivation of Solubilities of Long-Lived Radionuclides in Disposal." J. of Nucl. Mater., Vol. 130, p. 336-345.

Rich, R. A., H. D. Holland, and U. Peterson. 1977. "The Chemistry of Uranium Transport in Hydrothermal Fluids." Hydrothermal Uranium Deposits. Elsevier Scientific Publishing Co., New York, NY.

Ryan, J. L. and D. Rai. 1983. "The Solubility of Uranium(IV) Hydrous Dxide in Sodium Hydroxide Solutions Under Reducing Conditions." Polyhedron, Vol.2, No. 9, p. 947-952.

Schramke, J. A., S. A. Simonson, and D. G. Coles. 1984. A Report on the Status of Hydrothermal Testing of Fully Radioactive Waste Forms and Basalt Repository Waste Package Components. SD-BWI-TI-253, Rockwell Hanford Opera.tions, Richland, WA.

Schortmann, W. E. and M. A. DeSesa. 1958. "Kinetics of the Dissolution of Uranium Dioxide in Carbonate-Bicarbonate Solutions." Second United Nations International Conference on the Peaceful Uses of Atomic Energy - Proceedings, Vol. 3, p. 333-341.

Scott, P. D., 0. Glasser, and M. J. Nicol. 1977. "Kinetics of Dissolution of $\beta$-Uranium Trioxide in Acid and Carbonate Solutions," J. of the Chem. Soc., Dalton Transactions: Inorganic Chemistry, No. 2D, pp. 1939-1946.

Seyfried, H. E., Jr. and J. L. Bischoff. 1979. "Low Temperature Basalt Alteration by Sea Water: An Experimental Study at $70^{\circ} \mathrm{C}$ and $150^{\circ} \mathrm{C} . "$ Geochimica et Cosmochimica Acta, Vol. 43, p. 1937-1947.

Seyfried, W. E., Jr. and J. L. Bischoff. 1981. "Experimental Seawater-Basalt Interaction at $300^{\circ} \mathrm{C}, 500$ Bars, Chemical Exchange, Secondary Mineral Formation and Implications for the Transport of Heavy Metals," Geochimica et Cosmochimica Acta, Vol. 45, p. 135-147.

Shoesmith, D. H., S. Sunder, M. G. Bailey, and D. G. Owen. 1983. "Anodic 0xidation of $\mathrm{UO}_{2}$-Part III: Electrochemical Studies in Carbonate Solutions." Passivity of Metals and Semiconductors. Elsevier Publishers, New York, NY, p. $125-130$.

Shoesmith, D. W., S. Sunder, M. G. Bailey, G. J. Wallace, and S. F. Stanchell. 1984. "Anodic Oxidation of $\mathrm{UO}_{2}$, Part IV: X-Ray Photoelectron Spectroscopic. and Electrochemical Studies of Film Growth in Carbonate-Containing Solutions." Applications of Surface Science, Vol. 20, p. 39-57. 
Silva, R. J. and A. W. Yee. 1981. Uranium(VI) Retardation Mechanisms. LBL-136D0 (Earth Sciences Division Annual Report), Lawrence Berkely Laboratory, Berkely, CA.

Simonson, S. A. and W. L. Kuhn. 1984. Predicting Amounts of Radiolytically Produced Species in Brine Solutions." Scientific Basis for Nuclear Waste Management VII. Elsevier Science Publishing Co., New York, NY, p. 781-787.

Skytte-Jensen, B. 1980. The Geochemistry of Radionuclides with Long HalfLives: Their Expected Migration Behavior. RISO-R-430, Riso National Laboratory, Denmark.

Skytte-Jensen B. 1984. "The Applicability of Equilibrium Models, Kinetic Data, and the Use of Low-Temperature Experimental Data." The Geochemistry of HighLevel Waste Disposal in Granitic Rocks. AECL-8361, Whiteshell Nuclear Research Establishment, Pinawa, Manitoba.

Smith, R. M. and A. E. Martell. 1976. Critical Stability Constants. Vol.4. Inorganic Complexes. Plenum Press, New York, NY.

Sunder, S., D. W. Shoesmith, M. G. Bailey, F. W. Stanchell, and N. S. Mc Intyre. 1981. "Anodic Oxidation of $\mathrm{UO}_{2}$, Part I: Electrochemical and X-ray Photoelectron Spectroscopic Studies in Neutral Solutions." J. of Electroanalytical Chem., Vol. 130, p. 163-179.

Sunder, S., D. W. Shoesmith, M. G. Bailey, and. G. J. Wallace. 1982. "Mechanism of Oxidative Dissolution of $\mathrm{UO}_{2}$ Under Waste Disposal Vault Conditions." In Proceedings of International Conference on Radioactive Waste Management, September 1982, Winnipeg, Manitoba, Canada, Canadian Nuclear Society, Toronto, p. 398-405.

Sunder, S., D. W. Shoesmith, M. G. Bailey, and G. J. Wallace. 1983. "Anodic Oxidation of $\mathrm{UO}_{2}$, Part II: Electrochemical and X-Ray Photoelectron Spectroscopic Studies in Alkaline Solutions." J. of Electroanalytical Chem., Vol. 150, p. 217-228.

Thomas, G. F. and G. Till. 1984. "The Dissolution of Unirradiated $\mathrm{UO}_{2}$ Fuel Pellets Under Simulated Disposal Conditions." Nuclear and Chemical haste Management, Vol. 5, p. 141-147.

Tremaine, P. R. J. D. Chen, G. J. Wallace, and W. A. Boivin. 1981. "Solubi1ity of Uranium(IV) Oxide in Alkaline Aqueous Solutions to $300^{\circ} \mathrm{C} . " \mathrm{~J}$. of Solut. Chem., Vol. 10, No. 3, p. 221-230.

Truesdell, A. H. and B. F. Jones. 1974. "WATEQ: A Computer Program for Calculating Chemical Equilibria of Natural Waters," U.S. Geol. Surv. Jour. Research. 2: 233-248.

Vandergraaf, T. T. 1980. Leaching of Irradiated $\mathrm{UO}_{2}$ Fuel. TR-100, Whiteshell Nuclear Research Establishment, Pinawa, Manitoba, Canada. 
Vandergraaf, T. T., L. H. Johnson, and D. W. P. Lau, 1980. "Leaching of Irradiated CANDU $\mathrm{UO}_{2}$ Fuel." Scientific Basis for Nuclear Waste Management.

Vol. 2. Plenum Press, New York, NY, P. 335-342.

van Zeggeren, F. and S. H. Storey. 197D. The Computation of Chemical Equilibria. Cambridge University Press, Cambridge.

Wang, R. 1981. Spent Fuel Special Studies Progress Report: Probable Mechanisms for Oxidation and Dissolution of single-Crystal U0 $\mathrm{U}_{2}$ Surfaces. PNL3566, Pacific Northwest Laboratory, RichTand, WA.

Wang, R. and Y. B. Katayama. 1980. Electrochemical Methods for In-Situ Leaching of Spent Fuel. Presented at ORNL Conference on the Leachability of Radioactive Solids. PNL-SA-8934A, Pacific Northwest Laboratory, Richland, WA.

Wang, R. and Y. B. Katayama. 1981a. "Electrochemical Methods for Leaching of Spent Fuel." Nuclear and Chemical Waste Management. Vol. 2, No. 2,

p. 147-149.

Wang, R. and Y. B. Katayama. 1981b. "Probable Leaching Mechanisms for Spent Fuel." Alternate Nuclear Waste Forms and Interactions in Geologic Media. Conf-8005107, eds. L. A. Boatner and G. C. Battle, Gatlinburg, TN, P. 58-69.

Wang, R. and Y. B. Katayama. 1981C. "Probable Leaching Mechanisms for $\mathrm{UO}_{2}$ and Spent Fuel." Scientific Basis for Nuclear Waste Management, Vol. 3,

p. 379-386.

Wang, R. and Y. B. Katayama. 1982. "Dissolution Mechanisms for $\mathrm{UO}_{2}$ and Spent Fuel." Nuclear and Chemical Waste Management. Vol. 3, p. B3-90."

Weed, H. C. and D. D. Jackson. 1979. Design of a Variable Flow-Rate, SinglePass Leaching System. UCRL-52785, Lawrence Livermore National Laboratory, Livermore, CA.

Westa11, J. C., J. L. Zachary, and F. M. M. Morel. 1976. MINEQL, A Computer Program for the Calculation of Chemical Equilibrium Composition of Aqueous Systems, Technícal Note 18, Department Civil Engineering, Massachusetts Institute of Technology, Cambridge, Massachusetts.

Wilson, C. N. 1983. Test Plan for Spent Fuel Cladding Containment Credit Tests. HEDL-TC-2353-2. Hanford Engineering Development Laboratory, Richtand, WA.

Wilson, C. N. 1984. Test Plan for Series 2 Spent Fuel Cladding Containment Credit Tests. HEDL-TC-2353-3, Hanford Engineering Development Laboratory, Richland, WA.

Wilson, C. N. 1985. Results from NNWSI Series I Spent Fuel Leach Tests. HEDL-TME-84-3D. Hanford Engineering Development Laboratory, Richland, WA. 
Wilson, C. N. and V. M. Oversby. 1984. "Spent Fuel Cladding Containment Credit Tests." In Proceedings of "Waste Management '84, March 1984, Ed: Roy G. Post, Tucson, AZ.

Wilson, C. N. and V. M. Oversby. 1985. "Radionuclide Release from PWR Fuels in a Reference Tuff Repository Groundwater." In Proceedings of Waste Management '85, March 1985, Ed: Roy G. Post, Tucson, AZ.

Wolery, T. J., D. J. Isherwood, K. J. Jackson, J. M. Delany, and I. Puigdomenech. 1985. "EQ3/6: Status and Applications" in Proceedings of the Conference on the Application of Geochemical Models to High-Level Nuclear Waste Repository Assessment, ORNL/TM-9585, May 1985, Oak Ridge, TN.

Woodley, R. E., C. N. Wilson, and R. L. Hervig. 1981. Chemical and Physical Characteristics of Spent Light-Water-Reactor Fuel and a Method for Simulation of a Nonradioactive Analog. RHO-BWI-C-114, Rockwell Hanford Operations, Richland, WA.

Wolery, T. J. 1981. Chemical Modeling of Irreversible Reactions in Nuclear Waste/Water/Rock Systems. UCRL-85582, Lawrence Livermore National Laboratory, Livermore, CA.

Zeleznik, F. J. and S. Gordon. 1968. "Calculation of Complex Chemical Equilibria." Ind. Eng. Chem., Vol. 60, No. 6, p. 27-57. 


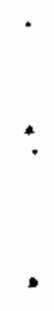




\section{DIGITIZED DATA SETS OF SPENT FUEL RELEASE}

The data contained in the following tables have been digitized from graphs appearing in documents that report results of spent fuel radionuclide release experiments. References, graph symbols, labels, and units are included with each set of data. Conditions under which the data were taken are described in the references; brief descriptions of the experimental conditions are given in Table 2. Data that have already been tabulated in the literature have not been included in this appendix. The tables in this appendix are organized in chronological order; the earliest data appear first, and the most recent data appear last.

The digitizing system used an HP plotter and sight pen in conjunction with a program written in IBM Advanced Basic. Duplicate measurements have confirmed that the system reads data from the graphs within plus or minus $10 \%$. 


\section{DIGITIZED DATA SETS}

REFERENCE: EKLUND AND FORSYTH 1978, FIGURE 3

FIGURE TITLE: 'UTLAKNINGSHASTIGHET FOR URANIUM'

$X$-AXES LABEL IS 'TIME (DAYS)'

CURVE 1

LABEL $=$ DISTILLED WATER $11.2 \mathrm{~kW} / \mathrm{m}$ SYMBOL = OPEN CIRCLE

\begin{tabular}{ccc}
$\begin{array}{cc}X \\
\text { COORDINATE }\end{array}$ & & $Y$ \\
\cline { 1 - 1 } & & COORDINATE \\
\cline { 1 - 1 } 2 & & $3.4 \mathrm{E}-06$ \\
3 & & $3.1 \mathrm{E}-06$ \\
6 & & $1.2 \mathrm{E}-06$ \\
11 & & $1.1 \mathrm{E}-06$ \\
21 & & $9.0 \mathrm{E}-07$ \\
35 & & $7.1 \mathrm{E}-07$ \\
56 & & $5.7 \mathrm{E}-07$ \\
86 & & $4.7 \mathrm{E}-07$
\end{tabular}

CURVE 3

LABEL $=$ GROUND WATER $23.5 \mathrm{~kW} / \mathrm{m}$ SYMBOL $=$ FILLED TR IANGLE

\begin{tabular}{|c|c|}
\hline $\begin{array}{c}x \\
\text { COORDINATE }\end{array}$ & $\begin{array}{c}Y \\
\text { COORDINATE }\end{array}$ \\
\hline $\begin{array}{r}2 \\
3 \\
6 \\
11 \\
21 \\
35 \\
55 \\
86\end{array}$ & $\begin{array}{l}\text { 8. } 3 E-05 \\
3.4 E-06 \\
8.2 E-07 \\
4.7 E-07 \\
4.7 E-07 \\
5.1 E-07 \\
3.1 E-07 \\
3.0 E-07\end{array}$ \\
\hline
\end{tabular}

\section{Y-AXES LABEL IS 'FRACTIONAL RELEASE RATE (1/DAYS $)^{\prime}$}

CURVE 2

\begin{tabular}{|c|c|}
\hline $\begin{array}{c}X \\
\text { COORDINATE } \\
\end{array}$ & $\begin{array}{c}Y \\
\text { COORDINATE } \\
\end{array}$ \\
\hline $\begin{array}{r}2 \\
3 \\
6 \\
11 \\
21 \\
35 \\
56 \\
86\end{array}$ & $\begin{array}{l}\text { 3. } 1 E-06 \\
2.4 E-06 \\
1.4 E-06 \\
1.5 E-06 \\
1.1 E-06 \\
1.0 E-06 \\
8.1 E-07 \\
6.7 E-07\end{array}$ \\
\hline
\end{tabular}

CURVE 4

LABEL $=$ DISTILLED WATER $23.5 \mathrm{~kW} / \mathrm{m}$ SYMBOL $=$ OPEN TRIANGLE

\begin{tabular}{|c|c|}
\hline $\begin{array}{c}X \\
\text { COORDINATE }\end{array}$ & $\begin{array}{c}Y \\
\text { COORDINATE }\end{array}$ \\
\hline $\begin{array}{r}2 \\
3 \\
6 \\
11 \\
21 \\
35 \\
55 \\
86\end{array}$ & $\begin{array}{l}6.4 \mathrm{E}-05 \\
3.4 \mathrm{E}-06 \\
1.4 \mathrm{E}-06 \\
1.5 \mathrm{E}-06 \\
1.3 \mathrm{E}-06 \\
1.2 \mathrm{E}-06 \\
8.7 \mathrm{E}-07 \\
6.6 \mathrm{E}-07\end{array}$ \\
\hline
\end{tabular}


REFERENCE: EKLUND AND FORSYTH 1978, FIGURE 4 FIGURE TITLE: 'UTLAKNINGSHASTIGHET FOR ${ }^{90} \mathrm{Sr}^{\prime}$

$X$-AXES LABEL IS 'TIME (DAYS)'

$Y$-AXES LABEL IS 'FRACTIONAL

RELEASE

RATE

(1/DAYS $)^{\prime}$

CURVE 1

LABEL = DISTILLED WATER $11.2 \mathrm{~kW} / \mathrm{m}$ SYMBOL = OPEN CIRCLE

\begin{tabular}{ccc}
$\begin{array}{ccc}x \\
\text { COORDINATE }\end{array}$ & & $\begin{array}{c}y \\
\text { COORDINATE }\end{array}$ \\
\cline { 1 - 1 } 2 & & $3.3 \mathrm{E}-05$ \\
3 & & $3.7 \mathrm{E}-06$ \\
6 & & $1.0 \mathrm{E}-06$ \\
11 & & $9.3 \mathrm{E}-07$ \\
20 & & $4.7 \mathrm{E}-07$ \\
33 & & $4.8 \mathrm{E}-07$ \\
52 & & $3.4 \mathrm{E}-07$ \\
81 & & $2.4 \mathrm{E}-07$
\end{tabular}

CURVE 3

\section{LABEL = DISTILLED WATER $23.5 \mathrm{~kW} / \mathrm{m}$} SYMBOL $=$ OPEN TRIANGLE

\begin{tabular}{ccc}
$\begin{array}{c}x \\
\text { COORDINATE }\end{array}$ & & $\begin{array}{c}Y \\
\text { COORDINATE }\end{array}$ \\
\cline { 1 - 1 } 2 & & $1.0 \mathrm{E}-04$ \\
6 & & $3.8 \mathrm{E}-06$ \\
10 & & $3.1 \mathrm{E}-06$ \\
20 & & $2.5 \mathrm{E}-06$ \\
33 & & $1.9 \mathrm{E}-06$ \\
53 & & $1.2 \mathrm{E}-06$ \\
82 & & $7.7 \mathrm{E}-07$
\end{tabular}

DRAWING NO. $=$ TPM-BL -133
CURVE 2

LABEL $=$ GROUND WATER $11.2 \mathrm{~kW} / \mathrm{m}$ SYMBOL = FILLED CIRCLE

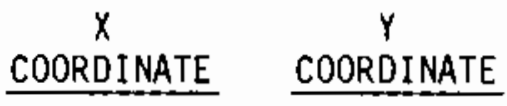

$\begin{array}{rr}2 & 3.7 \mathrm{E}-06 \\ 6 & 2.5 \mathrm{E}-06 \\ 11 & 6.8 \mathrm{E}-07 \\ 20 & 4.4 \mathrm{E}-07 \\ 33 & 3.2 \mathrm{E}-07 \\ 52 & 3.4 \mathrm{E}-07 \\ 82 & 2.4 \mathrm{E}-07\end{array}$

CURVE 4

LABEL $=$ GROUND WATER $23.5 \mathrm{~kW} / \mathrm{m}$ SYMBOL = FILLED TR IANGLE

\begin{tabular}{ccc}
$\begin{array}{ccc}X \\
\text { COORDINATE }\end{array}$ & & $\begin{array}{c}Y \\
\text { COORDINATE }\end{array}$ \\
\cline { 1 - 1 } 2 & & $1.3 \mathrm{E}-04$ \\
3 & & $1.2 \mathrm{E}-05$ \\
6 & & $9.0 \mathrm{E}-06$ \\
11 & & $9.8 \mathrm{E}-06$ \\
20 & & $7.4 \mathrm{E}-06$ \\
33 & & $2.4 \mathrm{E}-06$ \\
52 & & $1.5 \mathrm{E}-06$ \\
82 & & $6.7 \mathrm{E}-07$
\end{tabular}


REFERENCE: EXLUND AND FORSYTH 1978, FIGURE 5

FIGURE TITLE: 'UTLAKNINGSHASTIGHET FOR ${ }^{137}$ Cs '

$X$-AXES LABEL IS 'TIME (DAYS)'

CURVE 1

LABEL = DISTILLED WATER $11.2 \mathrm{~kW} / \mathrm{m}$
SYMBOL $=$ OPEN CIRCLE

\begin{tabular}{|c|c|}
\hline $\begin{array}{c}x \\
\text { COORDINATE }\end{array}$ & $\begin{array}{r}Y \\
\text { COORDINATE }\end{array}$ \\
\hline $\begin{array}{r}1 \\
2 \\
5 \\
10 \\
20 \\
33 \\
52 \\
82\end{array}$ & $\begin{array}{l}1.1 E-04 \\
6.1 E-06 \\
3.3 E-06 \\
2.5 E-06 \\
1.9 E-06 \\
1.6 E-06 \\
1.4 E-06 \\
1.3 E-06\end{array}$ \\
\hline
\end{tabular}

CURVE 3

LABEL $=$ DISTILLED WATER $25.5 \mathrm{~kW} / \mathrm{m}$

SYMBOL = OPEN TRIANGLE

\begin{tabular}{|c|c|}
\hline $\begin{array}{c}x \\
\text { COORDINATE }\end{array}$ & $\begin{array}{c}Y \\
\text { COORDINATE }\end{array}$ \\
\hline $\begin{array}{r}1 \\
2 \\
5 \\
10 \\
20 \\
33 \\
52 \\
82\end{array}$ & $\begin{array}{l}9.9 \mathrm{E}-04 \\
5.0 \mathrm{E}-04 \\
3.4 \mathrm{E}-04 \\
1.9 \mathrm{E}-04 \\
2.7 \mathrm{E}-05 \\
7.8 \mathrm{E}-06 \\
3.9 \mathrm{E}-06 \\
3.5 \mathrm{E}-06\end{array}$ \\
\hline
\end{tabular}

$Y$-AXES LABEL IS 'FRACTIONAL RELEASE
RATE (1/DAYS)'

CURVE 2

LABEL = GROUND WATER $11.2 \mathrm{~kW} / \mathrm{m}$

SYMBOL = FILLED CIRCLE

$\begin{array}{cc}\begin{array}{cc}X \\ \text { COORDINATE }\end{array} & \begin{array}{c}Y \\ \text { COORDINATE }\end{array} \\ 1 & \\ 2 & 1.2 \mathrm{E}-04 \\ 5 & 6.0 \mathrm{E}-06 \\ 10 & 2.3 \mathrm{E}-06 \\ 20 & 1.5 \mathrm{E}-06 \\ 33 & 1.0 \mathrm{E}-06 \\ 52 & 1.1 \mathrm{E}-06 \\ 82 & 1.5 \mathrm{E}-06 \\ & 1.8 \mathrm{E}-06\end{array}$

CURVE 4

LABEL $=$ GROUND WATER $23.5 \mathrm{~kW} / \mathrm{m}$ SYMBOL $=$ FILLED TRIANGLE

\begin{tabular}{ccc}
$\begin{array}{cc}X \\
\text { COORDINATE }\end{array}$ & & $\begin{array}{c}Y \\
\text { COORDINATE }\end{array}$ \\
\cline { 1 - 1 } 1 & & $9.9 \mathrm{E}-04$ \\
2 & & $4.8 \mathrm{E}-04$ \\
5 & & $3.1 \mathrm{E}-04$ \\
10 & & $2.1 \mathrm{E}-04$ \\
20 & & $7.6 \mathrm{E}-05$ \\
33 & & $1.5 \mathrm{E}-05$ \\
53 & & $3.0 \mathrm{E}-06$ \\
82 & & $.4 \mathrm{E}-06$
\end{tabular}


REFERENCE: VANDERGRAAF $1980, \mathrm{p}, 44$

FIGURE TITLE: 'DISSOLUTION RESULTS FOR URANIUM AS A FUNCTION OF TIME'

$x$-AXES LABEL IS 'TIME (DAYS)' Y-AXES LABEL IS 'FRACTIONAL RELEASE
RATE (1/DAYS)'

CURVE 1

LABEL = DISTILLED WATER
SYMBOL $=$ OPEN CIRCLE

\begin{tabular}{|c|c|c|c|}
\hline $\begin{array}{c}x \\
\text { COORDINATE } \\
\end{array}$ & $\begin{array}{c}Y \\
\text { COOROINATE } \\
\end{array}$ & $\begin{array}{c}x \\
\text { COORDINATE } \\
\end{array}$ & $\begin{array}{c}Y \\
\text { COORDINATE }\end{array}$ \\
\hline $\begin{array}{r}16 \\
25 \\
87 \\
93 \\
140 \\
200 \\
290 \\
290 \\
300 \\
300 \\
310 \\
300 \\
330 \\
350 \\
350 \\
360 \\
400 \\
400\end{array}$ & $\begin{array}{l}1.2 \mathrm{E}-05 \\
6.3 \mathrm{E}-05 \\
7.9 \mathrm{E}-06 \\
3.6 \mathrm{E}-06 \\
3.1 \mathrm{E}-06 \\
8.2 \mathrm{E}-05 \\
3.6 \mathrm{E}-05 \\
2.2 \mathrm{E}-06 \\
1.4 \mathrm{E}-06 \\
3.9 \mathrm{E}-05 \\
1.8 \mathrm{E}-04 \\
9.4 \mathrm{E}-07 \\
7.1 \mathrm{E}-07 \\
5.3 \mathrm{E}-06 \\
3.2 \mathrm{E}-06 \\
2.8 \mathrm{E}-06 \\
6.9 \mathrm{E}-07 \\
4.5 \mathrm{E}-07\end{array}$ & $\begin{array}{l}440 \\
460 \\
460 \\
770 \\
790 \\
790 \\
810 \\
810 \\
820 \\
820 \\
840 \\
840 \\
860 \\
860 \\
870 \\
870 \\
890 \\
890\end{array}$ & $\begin{array}{l}1.4 \mathrm{E}-07 \\
1.9 \mathrm{E}-07 \\
1.4 \mathrm{E}-07 \\
5.3 \mathrm{E}-07 \\
1.3 \mathrm{E}-06 \\
2.0 \mathrm{E}-07 \\
3.6 \mathrm{E}-06 \\
3.6 \mathrm{E}-07 \\
2.5 \mathrm{E}-06 \\
1.8 \mathrm{E}-07 \\
3.3 \mathrm{E}-06 \\
1.4 \mathrm{E}-07 \\
2.4 \mathrm{E}-06 \\
1.8 \mathrm{E}-07 \\
6.5 \mathrm{E}-07 \\
9.0 \mathrm{E}-08 \\
6.6 \mathrm{E}-\mathrm{D} 7 \\
5.6 \mathrm{E}-07\end{array}$ \\
\hline
\end{tabular}

A. 5 
REFERENCE: VANDERGRAAF 1980, p. 44 (contd)

\section{CURVE 2}

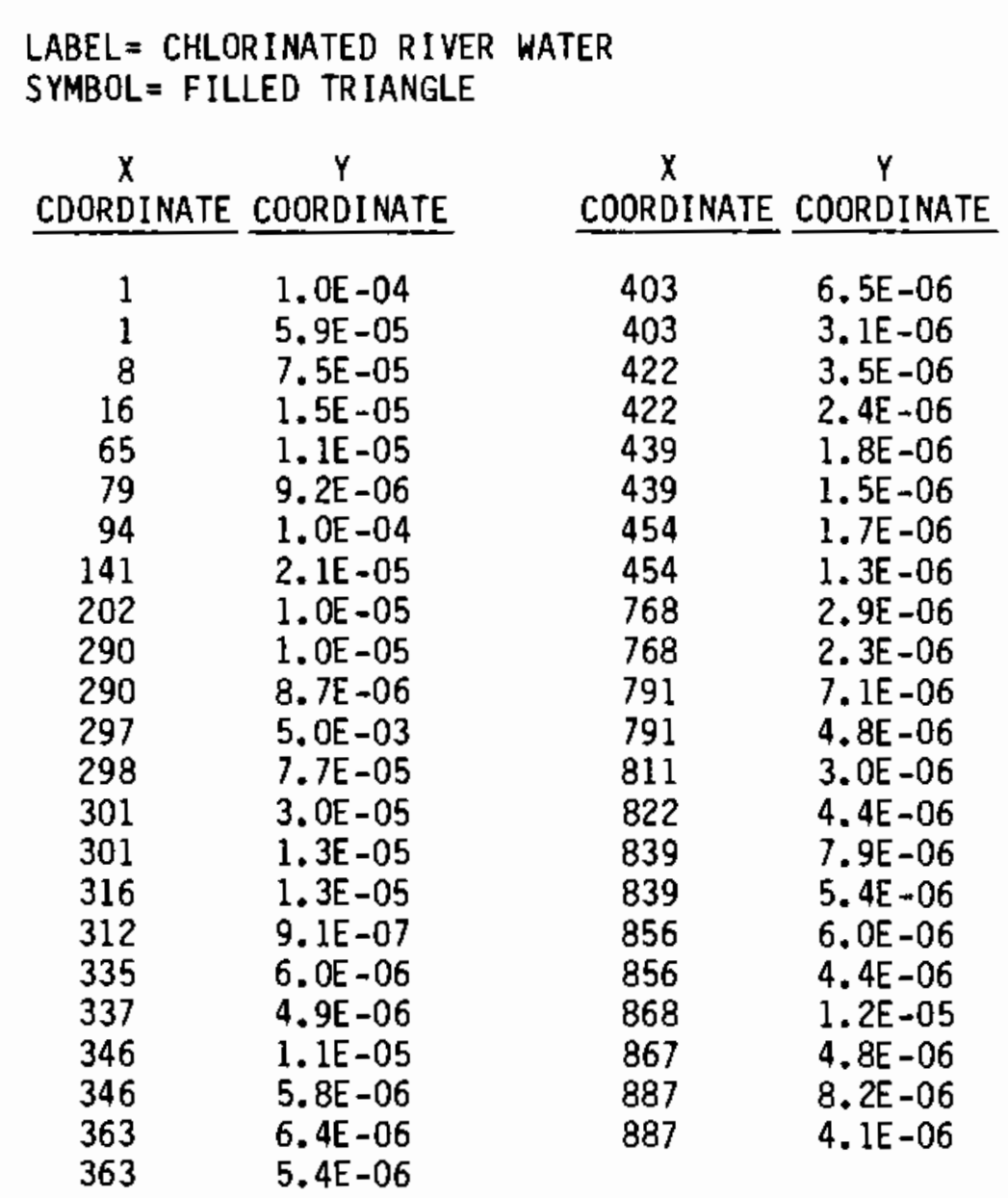


REFERENCE: VANDERGRAAF 1980 , p. 38

FIGURE TITLE: 'LEACHING RESULTS FOR ${ }^{137}$ CS AS A FUNCTION OF TIME'

$X$-AXES LABEL IS 'TIME (DAYS)' Y-AXES LABEL IS 'Bq (1/DAYS)'

CURVE 1

\begin{tabular}{|c|c|c|c|c|c|}
\hline $\begin{array}{c}x \\
\text { COORDINATE } \\
\end{array}$ & $\begin{array}{c}Y \\
\text { COORDINATE } \\
\end{array}$ & $\begin{array}{c}x \\
\text { COORDINATE } \\
\end{array}$ & $\begin{array}{c}Y \\
\text { COORDINATE } \\
\end{array}$ & $\begin{array}{c}x \\
\text { COORDINATE } \\
\end{array}$ & $\begin{array}{c}Y \\
\text { COORDINATE } \\
\end{array}$ \\
\hline $\begin{array}{r}0 \\
0 \\
0 \\
0 \\
0 \\
0 \\
10 \\
10 \\
12 \\
12 \\
17 \\
21 \\
21 \\
25 \\
29 \\
29 \\
33 \\
32 \\
38 \\
51 \\
51 \\
58 \\
58 \\
67 \\
67 \\
75 \\
74 \\
78 \\
78\end{array}$ & $\begin{array}{l}1.1 \mathrm{E}+09 \\
7.3 \mathrm{E}+08 \\
3.7 \mathrm{E}+08 \\
2.3 \mathrm{E}+08 \\
1.0 \mathrm{E}+08 \\
6.4 \mathrm{E}+07 \\
3.3 \mathrm{E}+07 \\
2.2 \mathrm{E}+07 \\
2.1 \mathrm{E}+07 \\
1.4 \mathrm{E}+07 \\
1.5 \mathrm{E}+07 \\
1.3 \mathrm{E}+07 \\
1.1 \mathrm{E}+07 \\
1.2 \mathrm{E}+07 \\
1.0 \mathrm{E}+07 \\
9.7 \mathrm{E}+06 \\
9.6 \mathrm{E}+06 \\
8.7 \mathrm{E}+06 \\
7.5 \mathrm{E}+06 \\
5.3 \mathrm{E}+06 \\
4.2 \mathrm{E}+06 \\
3.9 \mathrm{E}+06 \\
2.3 \mathrm{E}+06 \\
3.2 \mathrm{E}+06 \\
2.1 \mathrm{E}+06 \\
1.9 \mathrm{E}+06 \\
1.3 \mathrm{E}+06 \\
3.3 \mathrm{E}+06 \\
2.4 \mathrm{E}+06\end{array}$ & $\begin{array}{r}90 \\
90 \\
96 \\
96 \\
135 \\
136 \\
144 \\
145 \\
193 \\
193 \\
205 \\
2 D 5 \\
286 \\
287 \\
293 \\
293 \\
303 \\
303 \\
306 \\
306 \\
315 \\
315 \\
321 \\
323 \\
338 \\
338 \\
350 \\
350 \\
366\end{array}$ & $\begin{array}{l}1.1 \mathrm{E}+06 \\
8.5 \mathrm{E}+05 \\
9.5 \mathrm{E}+05 \\
1.4 \mathrm{E}+06 \\
8.7 \mathrm{E}+05 \\
6.3 \mathrm{E}+05 \\
1.0 \mathrm{E}+06 \\
7.4 \mathrm{E}+05 \\
8.7 \mathrm{E}+05 \\
3.9 \mathrm{E}+05 \\
3.8 \mathrm{E}+06 \\
8.7 \mathrm{E}+05 \\
4.1 \mathrm{E}+05 \\
1.4 \mathrm{E}+05 \\
8.6 \mathrm{E}+05 \\
4.5 \mathrm{E}+05 \\
5.6 \mathrm{E}+05 \\
3.9 \mathrm{E}+05 \\
6.8 \mathrm{E}+05 \\
3.5 \mathrm{E}+05 \\
1.1 \mathrm{E}+06 \\
3.1 \mathrm{E}+05 \\
7.3 \mathrm{E}+05 \\
2.8 \mathrm{E}+05 \\
6.4 \mathrm{E}+05 \\
2.1 \mathrm{E}+05 \\
3.6 \mathrm{E}+05 \\
7.3 \mathrm{E}+05 \\
2.5 \mathrm{E}+05\end{array}$ & $\begin{array}{l}368 \\
383 \\
408 \\
428 \\
428 \\
443 \\
443 \\
455 \\
455 \\
500 \\
500 \\
561 \\
561 \\
617 \\
618 \\
775 \\
800 \\
800 \\
819 \\
819 \\
832 \\
832 \\
848 \\
848 \\
866 \\
864 \\
876 \\
878 \\
905 \\
905\end{array}$ & $\begin{array}{l}6.5 \mathrm{E}+04 \\
1.1 \mathrm{E}+05 \\
1.5 \mathrm{E}+05 \\
7.3 \mathrm{E}+04 \\
2.5 \mathrm{E}+04 \\
2.3 \mathrm{E}+05 \\
1.7 \mathrm{E}+05 \\
1.5 \mathrm{E}+05 \\
6.3 \mathrm{E}+04 \\
8.1 \mathrm{E}+04 \\
4.6 \mathrm{E}+04 \\
9.6 \mathrm{E}+04 \\
6.4 \mathrm{E}+04 \\
7.2 \mathrm{E}+04 \\
6.0 \mathrm{E}+04 \\
8.2 \mathrm{E}+04 \\
8.4 \mathrm{E}+04 \\
5.2 \mathrm{E}+04 \\
1.3 \mathrm{E}+05 \\
1.1 \mathrm{E}+05 \\
1.6 \mathrm{E}+05 \\
5.1 \mathrm{E}+4 \\
3.4 \mathrm{E}+4 \\
2.0 \mathrm{E}+4 \\
1.0 \mathrm{E}+5 \\
8.7 \mathrm{E}+4 \\
7.9 \mathrm{E}+4 \\
3.5 \mathrm{E}+4 \\
9.8 \mathrm{E}+4 \\
8.7 \mathrm{E}+4\end{array}$ \\
\hline
\end{tabular}


REFERENCE: VANDERGRAAF 1980 p. 38 (contd)

CURVE 2

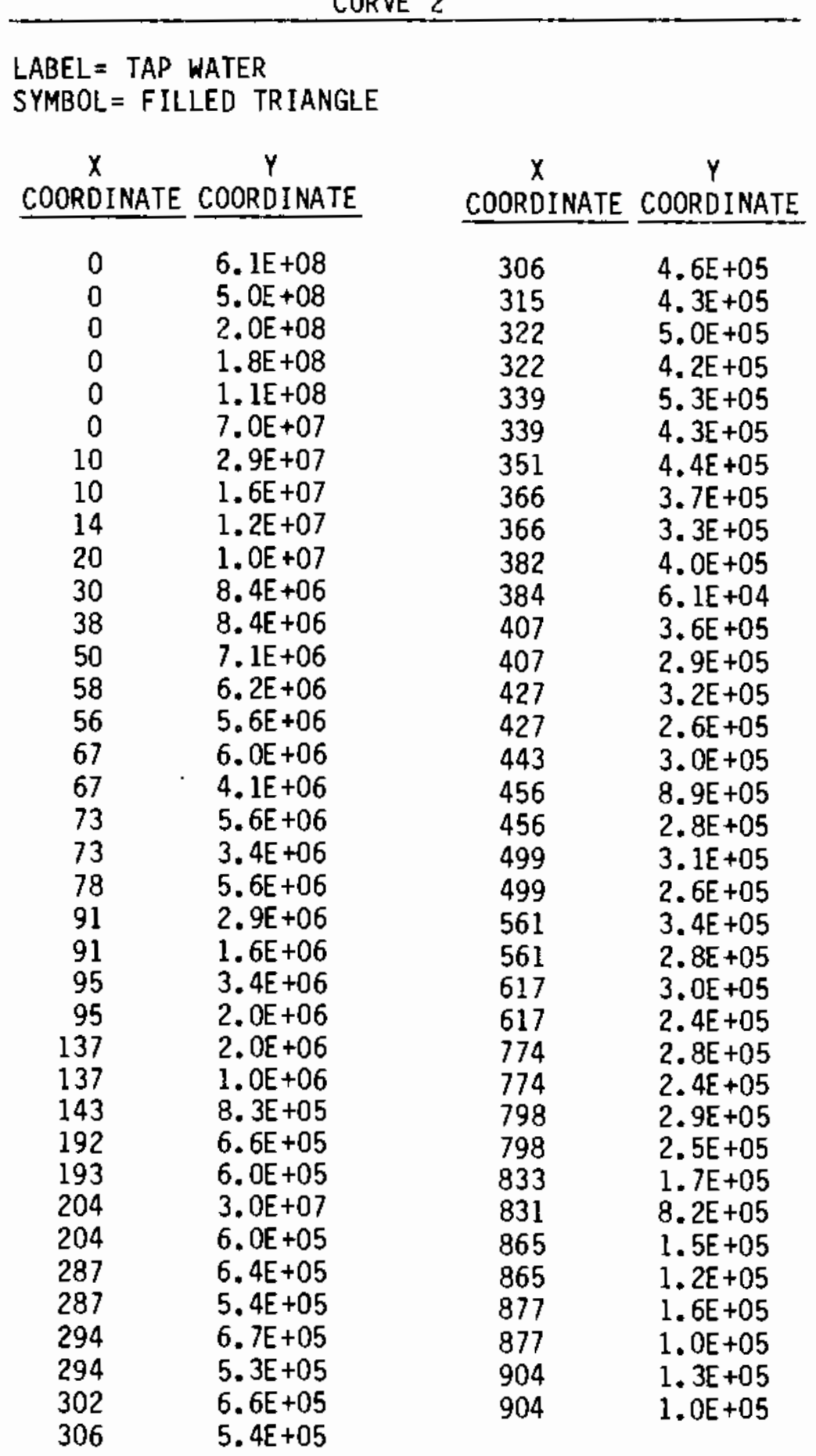


REFERENCE: VANDERGRAAF 1980 p. 34

FIGURE TITLE: 'LEACHING RESULTS FOR ${ }^{90} \mathrm{Sr}$ AS A FUNCTION OF TIME'

$X$-AXES LABEL IS 'TIME (DAYS)' Y-AXES LABEL IS 'Bq (1/DAYS)'

CURVE 1

$\angle A B E L=$ DIST ILLED WATER

SYMBOL $=$ OPEN CIRCLE

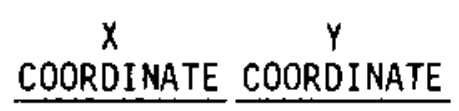

0

22

90

140

199

290

289

300

298

300

303

309

311

316

317

333

335

345

345 .

362

362

378

380

402
7. $5 \mathrm{E}+05$

5. $2 E+05$

5. $2 \mathrm{E}+05$

7. $7 \mathrm{E}+04$

4. $9 \mathrm{E}+06$

3. $0 \mathrm{E}+05$

4. $8 \mathrm{E}+04$

7. $8 \mathrm{E}+03$

5. $1 \mathrm{E}+04$

6. $8 E+03$

3. $6 \mathrm{E}+04$

5. $4 \mathrm{E}+03$

1. $2 E+05$

6. $9 E+03$

4. $9 E+04$

4. $7 \mathrm{E}+03$

4. $3 E+04$

4. $0 \mathrm{E}+03$

2. $0 \mathrm{E}+04$

3. $\mathrm{OE}+03$

2. $2 \mathrm{E}+04$

2. $2 \mathrm{E}+03$

1. $9 \mathrm{E}+04$

1. $0 \mathrm{E}+03$

6. $2 \mathrm{E}+03$

\begin{tabular}{cc}
$X$ & $y$ \\
COORDINATE & COORDINATE \\
\hline
\end{tabular}

402

423

424

450

452

496

496

556

556

614

612

769

792

795

814

814

825

825

842

842

858

858

868

870
1. $\mathrm{DE}+03$

7. $7 \mathrm{E}+03$

1. $1 E+03$

7. $2 \mathrm{E}+03$

1. $0 \mathrm{E}+03$

3. $6 \mathrm{E}+03$

6. $5 \mathrm{E}+02$

3. $2 \mathrm{E}+03$

1. $1 \mathrm{E}+02$

8. $9 \mathrm{E}+03$

2. $3 E+03$

1. $2 E+02$

1. $1 E+03$

3. $2 \mathrm{E}+02$

1. $8 \mathrm{E}+03$

7. $3 \mathrm{E}+02$

1. $3 E+03$

9. $3 E+02$

1. $9 \mathrm{E}+03$

2. $7 \mathrm{E}+02$

1. $8 \mathrm{E}+03$

5. $3 E+02$

1. $0 \mathrm{E}+03$

3. $3 E+02$ 
REFERENCE: VANDERGRAAF 1980, p. 34 (contd)

\begin{tabular}{|c|c|c|c|}
\hline \multicolumn{4}{|c|}{ CURVE 2} \\
\hline $\begin{array}{l}\text { LABEL }=\text { CHLC } \\
\text { SYMBOL = FIL }\end{array}$ & $\begin{array}{l}\text { RINATED RIVER } \\
\text { LED TRIANGLE }\end{array}$ & & \\
\hline $\begin{array}{c}x \\
\text { COORDINATE }\end{array}$ & $\begin{array}{c}Y \\
\text { COORDINATE } \\
\end{array}$ & $\begin{array}{c}x \\
\text { COORDINATE } \\
\end{array}$ & $\begin{array}{c}Y \\
\text { COORDINATE }\end{array}$ \\
\hline $\begin{array}{r}0 \\
0 \\
5 \\
14 \\
22 \\
62 \\
74 \\
91 \\
138 \\
200 \\
289 \\
289 \\
296 \\
301 \\
301 \\
295 \\
308 \\
317 \\
317 \\
335 \\
333 \\
345 \\
361 \\
378\end{array}$ & $\begin{array}{l}7.2 E+06 \\
2.5 E+06 \\
3 . D E+05 \\
2.3 E+05 \\
2.7 E+05 \\
1.1 E+05 \\
1.0 E+05 \\
1.9 E+05 \\
5.8 E+04 \\
3.0 E+04 \\
3.0 E+04 \\
2.6 E+04 \\
1.8 E+05 \\
5.2 E+04 \\
3.4 E+04 \\
3.7 E+06 \\
2.1 E+04 \\
4.2 E+04 \\
2.1 E+04 \\
2.6 E+04 \\
2.1 E+04 \\
2.4 E+04 \\
1.6 E+04 \\
2.0 E+04\end{array}$ & $\begin{array}{l}378 \\
403 \\
403 \\
421 \\
421 \\
439 \\
438 \\
450 \\
496 \\
556 \\
556 \\
597 \\
611 \\
769 \\
769 \\
792 \\
792 \\
813 \\
813 \\
824 \\
841 \\
841 \\
857 \\
869\end{array}$ & $\begin{array}{l}1.7 \mathrm{E}+04 \\
1.7 \mathrm{E}+04 \\
1.5 \mathrm{E}+04 \\
1.5 \mathrm{E}+04 \\
1.3 \mathrm{E}+04 \\
1.0 \mathrm{E}+04 \\
9.4 \mathrm{E}+03 \\
1.0 \mathrm{E}+04 \\
1.2 \mathrm{E}+04 \\
1.2 \mathrm{E}+04 \\
1.0 \mathrm{E}+04 \\
5.7 \mathrm{E}+05 \\
1.0 \mathrm{E}+04 \\
9.9 \mathrm{E}+03 \\
7.7 \mathrm{E}+03 \\
1.4 \mathrm{E}+04 \\
1.0 \mathrm{E}+04 \\
1.2 \mathrm{E}+04 \\
8.9 \mathrm{E}+03 \\
1.0 \mathrm{E}+04 \\
8.2 \mathrm{E}+03 \\
5.7 \mathrm{E}+03 \\
5.5 \mathrm{E}+03 \\
8.3 \mathrm{E}+03\end{array}$ \\
\hline
\end{tabular}


REFERENCE: VANDERGRAAF $1980, p .41$

FIGURE TITLE: 'LEACHING RESULTS FOR ${ }^{239} \mathrm{Pu}$ AND ${ }^{240} \mathrm{Pu}$ AS A FUNCTION OF TIME'

$X$-AXES LABEL IS 'TIME (DAYS)' Y-AXES LABEL IS 'Bq (1/DAYS)'

CURVE 1

\section{LABEL $=$ DISTILLED WATER \\ SYMBOL = OPEN CIRCLE}

\begin{tabular}{|c|c|c|c|c|c|}
\hline \multicolumn{2}{|c|}{$\begin{array}{cc}x & y \\
\text { COORDINATE } & \text { COORDINATE } \\
\end{array}$} & \multicolumn{2}{|c|}{$\begin{array}{cc}x & y \\
\text { COORDINATE } & \text { COORDINATE } \\
\end{array}$} & \multicolumn{2}{|c|}{$\begin{array}{c}X \\
Y \\
\text { COORDINATE } \\
\end{array}$} \\
\hline $\begin{array}{r}7 \\
25 \\
31 \\
209 \\
296 \\
304 \\
317 \\
325 \\
342 \\
385\end{array}$ & $\begin{array}{l}1.2 \mathrm{E}+02 \\
9.5 \mathrm{E}+02 \\
1.8 \mathrm{E}+03 \\
4.8 \mathrm{E}+02 \\
4.8 \mathrm{E}+02 \\
5.6 \mathrm{E}+02 \\
1.1 \mathrm{E}+03 \\
7.5 \mathrm{E}+02 \\
1.9 \mathrm{E}+01 \\
1.9 \mathrm{E}+02\end{array}$ & $\begin{array}{l}429 \\
444 \\
444 \\
461 \\
772 \\
797 \\
797 \\
816 \\
816 \\
827\end{array}$ & $\begin{array}{l}\text { 7. } 7 E+00 \\
1.2 E+01 \\
6.5 E+00 \\
1.1 E+01 \\
1.3 E+01 \\
1.4 E+01 \\
1.2 E+01 \\
8.2 E+00 \\
6.3 E+00 \\
3.2 E+00\end{array}$ & $\begin{array}{l}827 \\
845 \\
843 \\
860 \\
859 \\
873 \\
871 \\
899 \\
899\end{array}$ & $\begin{array}{l}2.7 \mathrm{E}+00 \\
7.4 \mathrm{E}+00 \\
2.5 \mathrm{E}+00 \\
1.1 \mathrm{E}+01 \\
3.1 \mathrm{E}+00 \\
4.6 \mathrm{E}+00 \\
3.9 \mathrm{E}+00 \\
1.4 \mathrm{E}+01 \\
1.1 \mathrm{E}+01\end{array}$ \\
\hline \multicolumn{6}{|c|}{ CURVE 2} \\
\hline
\end{tabular}

LABEL $=$ CHLORINATED RIVER WATER

SYMBOL = FILLED TR IANGLE

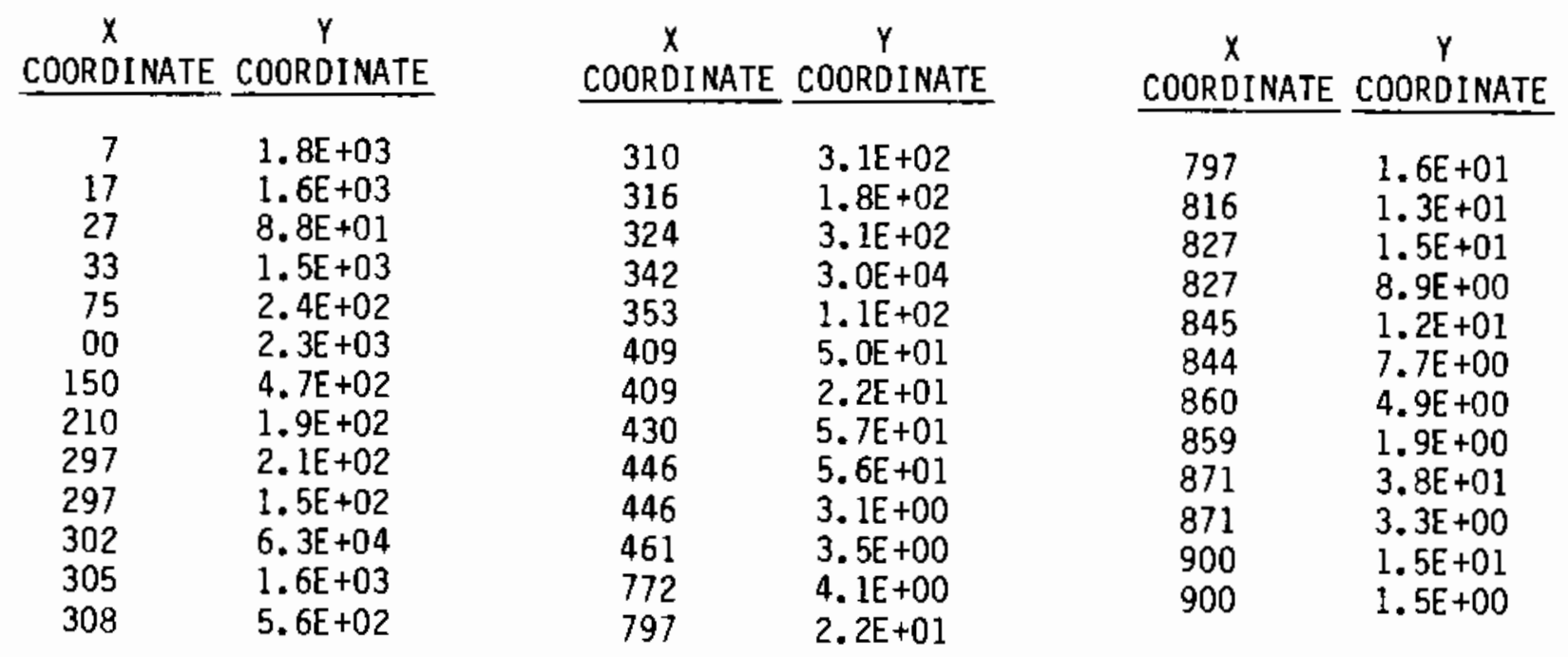


REFERENCE: VANDERGRAAF $1980, p, 39$

FIGURE TITLE: 'LEACHING RESULTS FOR ${ }^{144}$ Ce AS A FUNCTION OF TIME'

$X$-AXES LABEL IS 'TIME (DAYS)' Y-AXES LABEL IS 'Bq (1/DAYS)'

CURVE 1

\begin{tabular}{|c|c|c|c|c|c|}
\hline $\begin{array}{c}x \\
\text { COORDINATE } \\
\end{array}$ & $\begin{array}{c}Y \\
\text { COORDINATE } \\
\end{array}$ & $\begin{array}{c}x \\
\text { COORDINATE } \\
\end{array}$ & $\begin{array}{c}Y \\
\text { COOROINATE } \\
\end{array}$ & $\begin{array}{c}x \\
\text { COORDINATE } \\
\end{array}$ & $\begin{array}{c}Y \\
\text { COOROINATE } \\
\end{array}$ \\
\hline $\begin{array}{r}1 \\
1 \\
8 \\
8 \\
8 \\
8 \\
14 \\
14 \\
14 \\
25 \\
19 \\
19 \\
23 \\
26 \\
30 \\
30 \\
35 \\
35 \\
35 \\
39 \\
39 \\
34 \\
43 \\
43\end{array}$ & $\begin{array}{l}1.3 E+06 \\
3.6 E+05 \\
3.3 E+04 \\
1.1 E+04 \\
8.3 E+03 \\
5.9 E+03 \\
4.2 E+04 \\
3.6 E+04 \\
3.0 E+04 \\
6.1 E+01 \\
3.6 E+04 \\
2.1 E+04 \\
1.8 E+04 \\
2.6 E+04 \\
2.5 E+04 \\
2.0 E+04 \\
2.6 E+04 \\
1.4 E+04 \\
1.3 E+04 \\
2.9 E+04 \\
2.7 E+04 \\
1.5 E+04 \\
3.4 E+04 \\
2.3 E+04\end{array}$ & $\begin{array}{r}55 \\
55 \\
64 \\
64 \\
70 \\
70 \\
78 \\
78 \\
82 \\
82 \\
96 \\
96 \\
100 \\
138 \\
138 \\
146 \\
146 \\
193 \\
195 \\
207 \\
286 \\
294 \\
294 \\
304\end{array}$ & $\begin{array}{l}1.0 E+05 \\
1.0 E+04 \\
2.0 E+04 \\
1.6 E+04 \\
7.4 E+04 \\
4.6 E+04 \\
1.0 E+04 \\
5.8 E+03 \\
1.5 E+04 \\
1.0 E+04 \\
1.0 E+04 \\
9.4 E+03 \\
1.0 E+04 \\
3.3 E+03 \\
2.9 E+03 \\
9.3 E+03 \\
6.7 E+03 \\
4.3 E+04 \\
2.7 E+03 \\
5.9 E+03 \\
1.3 E+03 \\
7.5 E+03 \\
4.6 E+03 \\
1.1 E+04\end{array}$ & $\begin{array}{l}304 \\
307 \\
307 \\
314 \\
316 \\
406 \\
406 \\
426 \\
426 \\
443 \\
443 \\
458 \\
458 \\
499 \\
499 \\
558 \\
558 \\
615 \\
614 \\
769 \\
793 \\
814 \\
814\end{array}$ & $\begin{array}{l}3.3 \mathrm{E}+03 \\
2.0 \mathrm{E}+04 \\
2.6 \mathrm{E}+03 \\
1.0 \mathrm{E}+05 \\
6.4 \mathrm{E}+03 \\
2.2 \mathrm{E}+02 \\
1.3 \mathrm{E}+02 \\
4.2 \mathrm{E}+02 \\
2.6 \mathrm{E}+03 \\
1.1 \mathrm{E}+02 \\
6.4 \mathrm{E}+02 \\
1.0 \mathrm{E}+03 \\
4.2 \mathrm{E}+02 \\
1.6 \mathrm{E}+02 \\
6.7 \mathrm{E}+01 \\
2.7 \mathrm{E}+02 \\
2.0 \mathrm{E}+02 \\
3.4 \mathrm{E}+02 \\
1.3 \mathrm{E}+02 \\
2.4 \mathrm{E}+02 \\
1.1 \mathrm{E}+02 \\
1.2 \mathrm{E}+02 \\
5.0 \mathrm{E}+01\end{array}$ \\
\hline
\end{tabular}


REFERENCE: VANDERGRAAF 1980, p. 39 (contd)

CURVE 2

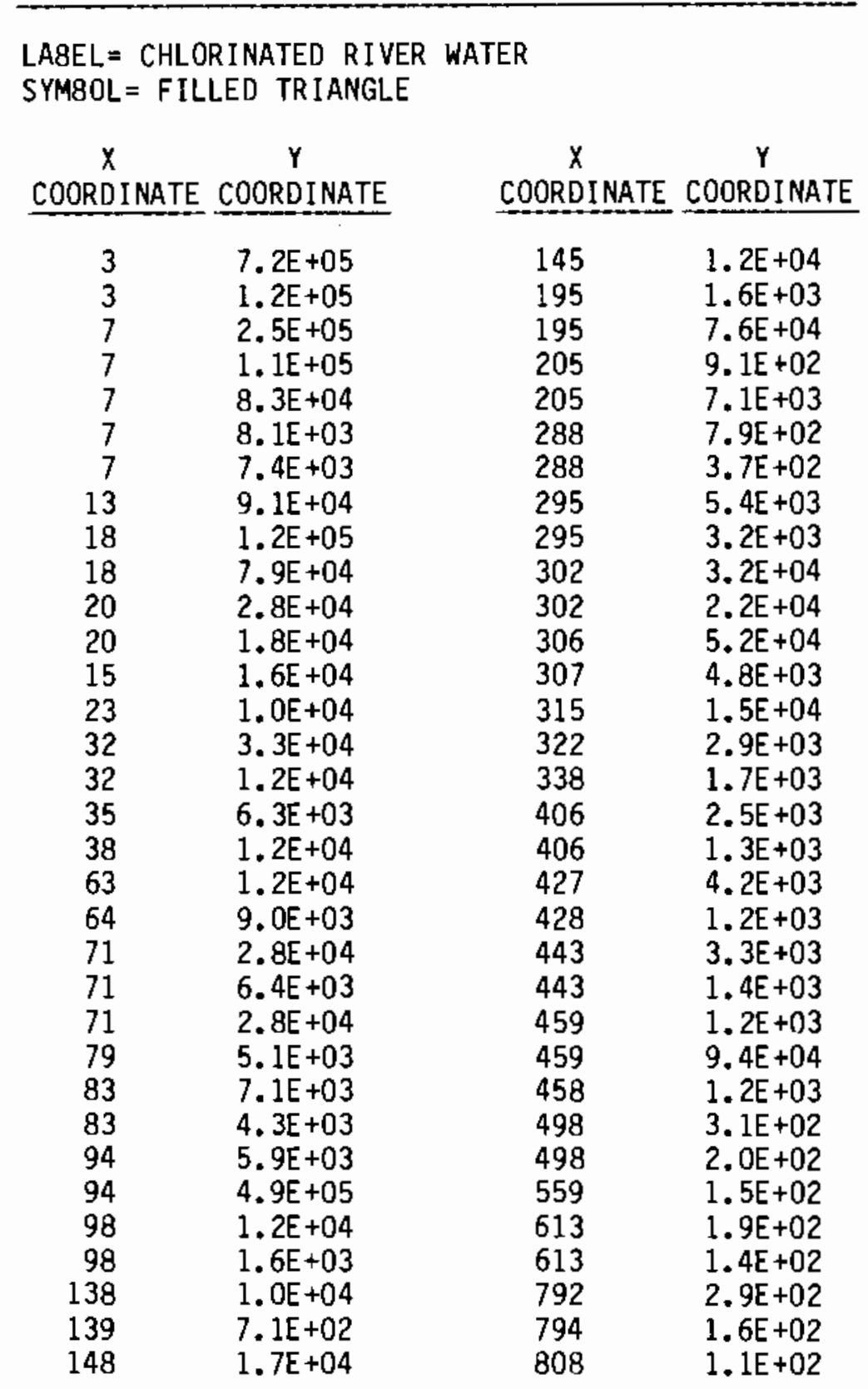


REFERENCE: MITCHELL, GOODE AND VAUGHEN 1981, p. 11

FIGURE TITLE: 'LEACH RATES FOR URANIUM'

$X$-AXES LABEL IS 'TIME (OAYS)'

CURVE 1

\section{LABEL $=85-18$ URANIUM \\ SYMBOL = OPEN SQUARE}

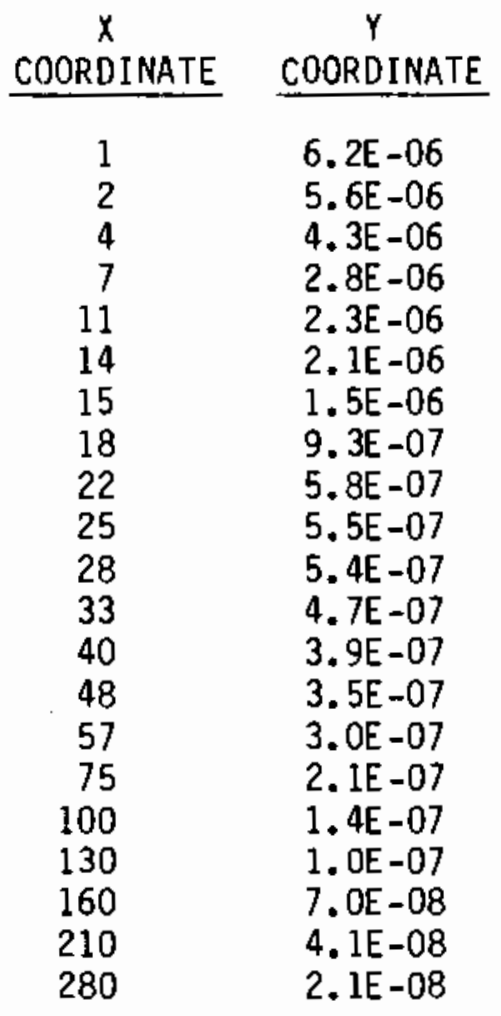

Y-AXES LABEL IS 'LEACH RATE'

CURVE 2

LABEL $=85-200$ URANIUM
SYMBOL $=$ FILLED CIRCLE

$x$ COORDINATE COORDINATE

2

6. $2 \mathrm{E}-07$

$5.2 \mathrm{E}-07$

4. $8 \mathrm{E}-07$

4. $2 \mathrm{E}-07$

3. $3 \mathrm{E}-07$

2.5E-07

2. $1 \mathrm{E}-07$

2. $0 \mathrm{E}-07$

$1.8 \mathrm{E}-07$

$1.4 \mathrm{E}-07$

1. $2 \mathrm{E}-07$

1. $1 \mathrm{E}-07$

7. $9 \mathrm{E}-08$

5. $3 \mathrm{E}-08$

4. $2 \mathrm{E}-08$

3. $8 \mathrm{E}-08$

3. $1 \mathrm{E}-08$

2. $0 \mathrm{E}-08$

1. $4 \mathrm{E}-08$ 
REFERENCE: MITCHELL, GOODE AND VAUGHEN 1981, p. 11 (contd)

CURVE 3

LABEL $=100-18$ URANIUM

SYMBOL = OPEN CIRCLE

$x$ COORDINATE COORDINATE

1

5

11

14

15

18

26

33

40

48

57

75

100

130

160

210

280
2. $4 \mathrm{E}-06$

8. $6 \mathrm{E}-07$

4. $5 \mathrm{E}-07$

3. $0 \mathrm{E}-07$

1. $9 \mathrm{E}-07$

$1.4 \mathrm{E}-07$

$1.2 \mathrm{E}-07$

9. $4 \mathrm{E}-08$

7. $8 \mathrm{E}-08$

7. $6 \mathrm{E}-08$

$6.4 \mathrm{E}-08$

3. $9 \mathrm{E}-08$

2. $2 \mathrm{E}-08$

$1.8 \mathrm{E}-08$

1. $3 \mathrm{E}-08$

5. $6 \mathrm{E}-09$

2. $9 \mathrm{E}-09$
CURVE 4

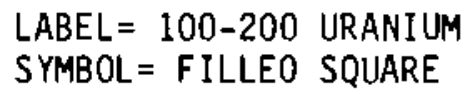

$x$ COORDINATE COORDINATE

1

$5.6 \mathrm{E}-07$

5. $1 \mathrm{E}-07$

3. $5 \mathrm{E}-07$

2. $6 \mathrm{E}-07$

2. $2 \mathrm{E}-07$

2. $0 \mathrm{E}-07$

2.1E -07

2. $5 \mathrm{E}-07$

2. $3 \mathrm{E}-07$

$1.6 \mathrm{E}-07$

8. $5 \mathrm{E}-08$

$5.2 \mathrm{E}-08$

4. $4 \mathrm{E}-08$

4. $1 \mathrm{E}-08$

3. $4 \mathrm{E}-08$

2. $2 \mathrm{E}-08$

$1.6 \mathrm{E}-08$

$1.3 \mathrm{E}-08$

1. $2 \mathrm{E}-08$

1. $2 \mathrm{E}-08$

ORAWING NO. = ORNL-DWG $-80-1454$ 
REFERENCE: MITCHELL, GOODE AND VAUGHEN 1981, p. 14

FIGURE TITLE: 'LEACH RATES FOR ${ }^{144} \mathrm{Ce}$ '

$X$-AXES LABEL IS 'TIME (DAYS)' CURVE 1

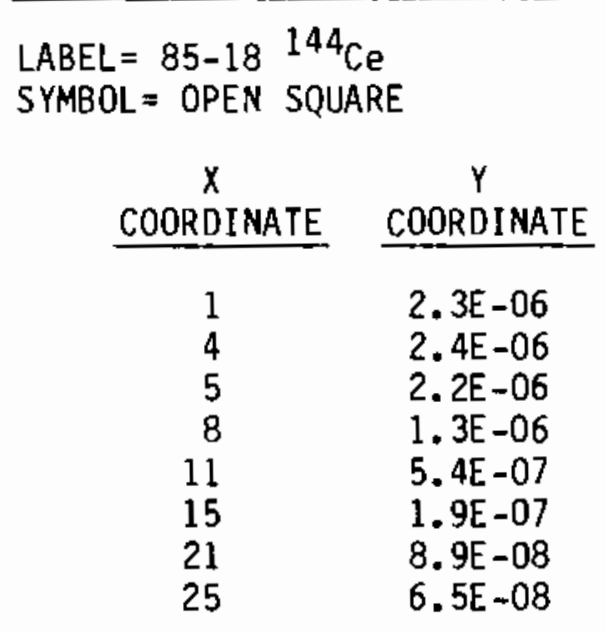

$Y$-AXES LABEL IS 'LEACH RATE'

CURVE 2

LABEL $=85-200{ }^{144} \mathrm{Ce}$
SYMBOL $=$ FILLED CIRCLE

\begin{tabular}{ccc}
$\begin{array}{c}X \\
\text { COORDINATE }\end{array}$ & $\begin{array}{c}Y \\
\text { COORDINATE }\end{array}$ \\
\cline { 1 - 1 } 4 & & $2.4 \mathrm{E}-07$ \\
6 & & $2.2 \mathrm{E}-07$ \\
7 & & $1.5 \mathrm{E}-07$ \\
9 & & $9.0 \mathrm{E}-08$ \\
10 & $5.7 \mathrm{E}-08$ \\
15 & $4.0 \mathrm{E}-08$ \\
21 & $2.8 \mathrm{E}-08$ \\
25 & $2.2 \mathrm{E}-08$ \\
30 & $2.2 \mathrm{E}-08$ \\
38 & $2.3 \mathrm{E}-08$ \\
45 & $2.3 \mathrm{E}-08$ \\
55 & $1.8 \mathrm{E}-08$ \\
72 & $1.1 \mathrm{E}-08$ \\
97 & $9.4 \mathrm{E}-09$ \\
127 & $1.0 \mathrm{E}-08$ \\
162 & $1.2 \mathrm{E}-08$ \\
211 & $1.4 \mathrm{E}-08$ \\
278 & $1.4 \mathrm{E}-08$
\end{tabular}


REFERENCE: MITCHELL, GOODE AND VAUGHEN 1981, p. 14 (contd)

CURVE 3

LABEL $=100-18^{144} \mathrm{Ce}$

SYMBOL = OPEN CIRCLE

\begin{tabular}{|c|c|}
\hline $\begin{array}{c}x \\
\text { COORDINATE }\end{array}$ & $\begin{array}{c}Y \\
\text { COORDINATE }\end{array}$ \\
\hline $\begin{array}{r}0 \\
4 \\
6 \\
7 \\
10 \\
11 \\
14 \\
18 \\
20 \\
23 \\
24 \\
28 \\
40 \\
73 \\
25\end{array}$ & $\begin{array}{l}\text { 4. } 9 \mathrm{E}-06 \\
2.9 \mathrm{E}-06 \\
1.3 \mathrm{E}-06 \\
8.1 \mathrm{E}-07 \\
6.2 \mathrm{E}-07 \\
5.0 \mathrm{E}-07 \\
3.1 \mathrm{E}-07 \\
1.5 \mathrm{E}-07 \\
1.1 \mathrm{E}-07 \\
1.0 \mathrm{E}-07 \\
7.3 \mathrm{E}-08 \\
4.6 \mathrm{E}-08 \\
3.0 \mathrm{E}-08 \\
2.5 \mathrm{E}-08 \\
2.4 \mathrm{E}-08\end{array}$ \\
\hline
\end{tabular}

CURVE 4

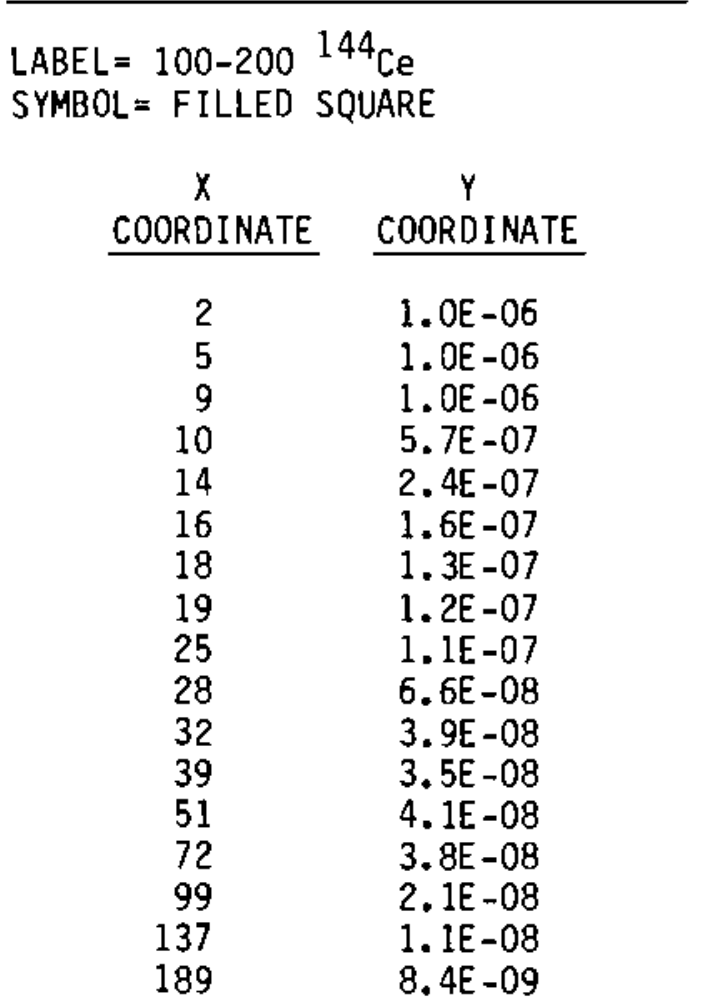

ORAWING NO. ORNL-DWG-80-1456 
REFERENCE: MITCHELL, GOODE AND VAUGHEN 1981, p. 15

FIGURE TITLE: 'LEACH RATES FOR ${ }^{154}$ Eu'

$X$-AXES LABEL IS 'TIME (DAYS)' CURVE 1

$\angle A B E L=85-18{ }^{154} \mathrm{Eu}$

SYMBOL = OPEN SQUARE

$\begin{array}{ccc}X & Y \\ \text { COORDINATE } & & \text { COORDINATE } \\ 2 & & 6.2 E-06 \\ 8 & & 6.2 E-06 \\ 11 & & 6.3 E-06\end{array}$

CURVE 3

LABEL $=100-188^{154}$ EU
SYMBOL $=$ OPEN CIRCLE

\begin{tabular}{ccc}
$\begin{array}{cc}X \\
\text { COOROINATE }\end{array}$ & & $Y$ \\
\cline { 1 - 1 } 3 & COORDINATE \\
5 & & $3.0 \mathrm{E}-06$ \\
8 & & $1.8 \mathrm{E}-06$ \\
10 & & $1.2 \mathrm{E}-06$ \\
10 & & $9.5 \mathrm{E}-07$ \\
13 & & $6.3 \mathrm{E}-07$ \\
19 & & $2.7 \mathrm{E}-07$ \\
27 & & $1.2 \mathrm{E}-07$ \\
41 & & $5.2 \mathrm{E}-08$ \\
65 & & $2.9 \mathrm{E}-08$
\end{tabular}

Y-AXES LABEL IS 'LEACH RATE' CURVE 2

$\angle A B E L=85-2000^{154} E U$

SYMBOL $=$ FILLED CIRCLE

\begin{tabular}{cc}
$x$ & $y$ \\
COORDINATE & COORDINATE \\
\hline
\end{tabular}

$\begin{array}{rr}5 & 1.3 \mathrm{E}-06 \\ 7 & 8.6 \mathrm{E}-07 \\ 9 & 3.6 \mathrm{E}-07 \\ 10 & 2.1 \mathrm{E}-07 \\ 20 & 1.3 \mathrm{E}-07 \\ 48 & 4.7 \mathrm{E}-08 \\ 91 & 1.9 \mathrm{E}-08 \\ 127 & 1.5 \mathrm{E}-08 \\ 161 & 1.5 \mathrm{E}-08 \\ 210 & 1.4 \mathrm{E}-08 \\ 277 & 1.4 \mathrm{E}-08\end{array}$

CURVE 4

LABEL $=100-200{ }^{154} \mathrm{Eu}$
SYMBOL $=$ FILLED SQUARE

\begin{tabular}{|c|c|}
\hline $\begin{array}{c}x \\
\text { COOROINATE }\end{array}$ & $\begin{array}{c}Y \\
\text { CDOROINATE }\end{array}$ \\
\hline $\begin{array}{r}3 \\
4 \\
9 \\
10 \\
12 \\
14 \\
16 \\
19 \\
21 \\
30 \\
38 \\
51 \\
71 \\
98 \\
136 \\
188\end{array}$ & $\begin{array}{l}1.2 \mathrm{E}-06 \\
9.3 \mathrm{E}-07 \\
6.7 \mathrm{E}-07 \\
3.7 \mathrm{E}-07 \\
2.5 \mathrm{E}-07 \\
2.2 \mathrm{E}-07 \\
1.6 \mathrm{E}-07 \\
1.2 \mathrm{E}-07 \\
1.1 \mathrm{E}-07 \\
9 . \mathrm{E}-08 \\
5.9 \mathrm{E}-08 \\
4.8 \mathrm{E}-08 \\
3.2 \mathrm{E}-08 \\
1.4 \mathrm{E}-08 \\
1.0 \mathrm{E}-08 \\
9.6 \mathrm{E}-09\end{array}$ \\
\hline
\end{tabular}

DRAWING NO. = ORNL - OWG-80-1457 
REFERENCE: MITCHELL, GOODE AND VAUGHEN 1981, p. 17

FIGURE TITLE: 'LEACH RATES FOR ${ }^{137} \mathrm{Cs}$ '

$X$-AXES LABEL IS 'TIME (DAYS)'

$Y$-AXES LABEL IS 'LEACH RATE'

CURVE 1

LABEL $=85-18{ }^{137} \mathrm{Cs}$
SYMBOL $=$ OPEN SQUARE

\begin{tabular}{c}
$x$ \\
COORDINATE \\
\hline
\end{tabular}

$\begin{array}{rr}1 & 2.7 \mathrm{E}-04 \\ 3 & 9.0 \mathrm{E}-05 \\ 6 & 3.7 \mathrm{E}-05 \\ 7 & 1.8 \mathrm{E}-05 \\ 9 & 1.0 \mathrm{E}-05 \\ 10 & 8.6 \mathrm{E}-06 \\ 12 & 7.2 \mathrm{E}-06 \\ 14 & 6.2 \mathrm{E}-06 \\ 16 & 5.0 \mathrm{E}-06 \\ 19 & 3.5 \mathrm{E}-06 \\ 21 & 2.7 \mathrm{E}-06 \\ 24 & 2.5 \mathrm{E}-06 \\ 25 & 2.3 \mathrm{E}-06 \\ 29 & 1.9 \mathrm{E}-06 \\ 34 & 1.6 \mathrm{E}-06 \\ 40 & 1.4 \mathrm{E}-06 \\ 48 & 1.2 \mathrm{E}-06 \\ 58 & 9.2 \mathrm{E}-07 \\ 75 & 6.3 \mathrm{E}-07 \\ 100 & 5.1 \mathrm{E}-07 \\ 129 & 4.7 \mathrm{E}-07 \\ 162 & 4.3 \mathrm{E}-07 \\ 210 & 2.6 \mathrm{E}-07 \\ 278 & 1.1 \mathrm{E}-07\end{array}$

CURVE 2
LABEL $=85-200{ }^{137} \mathrm{CS}$
SYMBOL $=$ FILLED CIRCLE

\begin{tabular}{cc}
$x$ & \multicolumn{1}{c}{} \\
COORDINATE & COORDINATE \\
\hline
\end{tabular}

$\begin{array}{rr}2 & 6.3 \mathrm{E}-05 \\ 5 & 2.0 \mathrm{E}-06 \\ 7 & 1.1 \mathrm{E}-06 \\ 9 & 8.3 \mathrm{E}-07 \\ 10 & 7.3 \mathrm{E}-07 \\ 11 & 7.0 \mathrm{E}-07 \\ 14 & 6.3 \mathrm{E}-07 \\ 16 & 5.9 \mathrm{E}-07 \\ 19 & 5.1 \mathrm{E}-07 \\ 21 & 4.1 \mathrm{E}-07 \\ 24 & 3.6 \mathrm{E}-07 \\ 25 & 3.5 \mathrm{E}-07 \\ 29 & 3.6 \mathrm{E}-07 \\ 34 & 3.7 \mathrm{E}-07 \\ 40 & 3.8 \mathrm{E}-07 \\ 48 & 3.5 \mathrm{E}-07 \\ 58 & 2.5 \mathrm{E}-07 \\ 75 & 1.7 \mathrm{E}-07 \\ 100 & 1.4 \mathrm{E}-07 \\ 129 & 1.6 \mathrm{E}-07 \\ 162 & 1.6 \mathrm{E}-07 \\ 210 & 1.6 \mathrm{E}-07 \\ 278 & 1.6 \mathrm{E}-07\end{array}$


REFERENCE: MITCHELL, GOODE AND VAUGHEN 1981, p. 17 (contd)

CURVE 3

LABEL $=100-18{ }^{137} \mathrm{CS}$
SYMBOL $=$ OPEN CIRCLE

$x$ COORDINATE COOROINATE

1
4
7

1
4
7
9

10

12

15

16

21

24

26

29

34

41

48

58

75

100

130

163

211

278
3. $9 E-04$

7. OE-05

9. $8 \mathrm{E}-06$

6. 1E-06

4. $4 E-06$

3. $9 \mathrm{E}-06$

3. $4 \mathrm{E}-06$

2. 5E-06

2. $6 E-06$

2. $4 \mathrm{E}-06$

2. $0 E-06$

1. $4 \mathrm{E}-06$

1. $0 E-06$

8. $8 \mathrm{E}-07$

8. $3 E-07$

6. $8 E-07$

4. 5E-07

3. $6 \mathrm{E}-07$

3. $8 \mathrm{E}-07$

3. $7 \mathrm{E}-07$

2. $6 \mathrm{E}-07$

$1.3 E-07$
CURVE 4

LABEL $=100-200{ }^{137} \mathrm{CS}$
SYMBOL $=$ FILLED SQUARE

SYMBOL = FILLED SQUARE

\begin{tabular}{ccc}
$\begin{array}{cc}X \\
\text { COOROINATE }\end{array}$ & \multicolumn{1}{c}{$\begin{array}{c}Y \\
\text { COORDINATE }\end{array}$} \\
2 & & $1.1 \mathrm{E}-05$ \\
3 & & $7.2 \mathrm{E}-06$ \\
3 & & $4.5 \mathrm{E}-06$ \\
5 & & $2.4 \mathrm{E}-06$ \\
5 & & $2.1 \mathrm{E}-06$ \\
7 & & $1.7 \mathrm{E}-06$ \\
9 & & $1.3 \mathrm{E}-06$ \\
11 & & $1.0 \mathrm{E}-06$ \\
12 & & $8.2 \mathrm{E}-07$ \\
14 & & $7.0 \mathrm{E}-07$ \\
19 & & $5.9 \mathrm{E}-07$ \\
22 & & $6.5 \mathrm{E}-07$ \\
24 & & $6.8 \mathrm{E}-07$ \\
26 & & $6.6 \mathrm{E}-07$ \\
29 & & $4.7 \mathrm{E}-07$ \\
34 & & $3.0 \mathrm{E}-07$ \\
41 & $2.5 \mathrm{E}-07$ \\
48 & $2.5 \mathrm{E}-07$ \\
58 & $2.4 \mathrm{E}-07$ \\
75 & $2.1 \mathrm{E}-07$ \\
100 & $1.9 \mathrm{E}-07$ \\
162 & $1.3 \mathrm{E}-07$ \\
211 & $1.1 \mathrm{E}-07$ \\
278 & $9.9 \mathrm{E}-08$
\end{tabular}


REFERENCE: MITCHELL, GOODE AND VAUGHEN 1981, p. 18 FIGURE TITLE: 'LEACH RATES FOR $129^{\prime}$ '

$X$-AXES LABEL IS 'TIME (DAYS)'

CURVE 1

$$
\begin{aligned}
& \text { LABEL }=85-18{ }^{129} \mathrm{I} \\
& \text { SYMBOL }=\text { OPEN SQUARE }
\end{aligned}
$$

\begin{tabular}{ccc}
$\begin{array}{cc}X \\
\text { COORDINATE }\end{array}$ & & $\begin{array}{c}Y \\
\text { COORDINATE }\end{array}$ \\
\cline { 1 - 1 } 0 & & $3.8 \mathrm{E}-04$ \\
9 & & $3.5 \mathrm{E}-04$ \\
12 & & $5.2 \mathrm{E}-04$ \\
$10 \mathrm{D}$ & & $3.2 \mathrm{E}-06$ \\
131 & & $1.0 \mathrm{E}-06$ \\
163 & & $1.1 \mathrm{E}-06$ \\
280 & & $1.1 \mathrm{E}-06$
\end{tabular}

CURVE 3

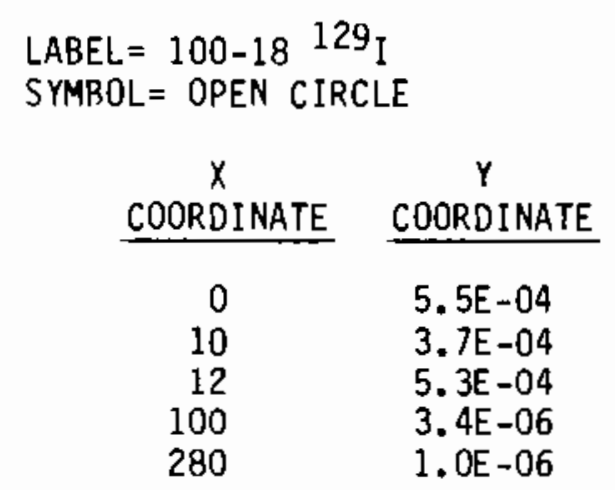

$Y$-AXES LABEL IS 'LEACH RATE'

\begin{tabular}{|c|c|}
\hline \multicolumn{2}{|c|}{$\begin{array}{l}\text { LABEL }=85-200{ }^{129} \mathrm{I} \\
\text { SYMBOL }=\text { FILLED CIRCLE }\end{array}$} \\
\hline $\begin{array}{c}x \\
\text { COORDINATE }\end{array}$ & $\begin{array}{c}Y \\
\text { COORDINATE }\end{array}$ \\
\hline $\begin{array}{r}0 \\
9 \\
12 \\
100 \\
131 \\
163 \\
280\end{array}$ & $\begin{array}{l}1.4 \mathrm{E}-04 \\
4.1 \mathrm{E}-05 \\
6.1 \mathrm{E}-05 \\
4.1 \mathrm{E}-07 \\
1.6 \mathrm{E}-07 \\
4.0 \mathrm{E}-07 \\
2.6 \mathrm{E}-07\end{array}$ \\
\hline
\end{tabular}

CURVE 2

CURVE 4

DRAWING NO. = ORNL-DWG-80-1450 
REFERENCE: MITCHELL, GOODE AND VAUGHEN, $p, 21$

FIGURE TITLE: 'LEACH RATES FOR ${ }^{125}$ Sb'

$X$-AXES LABEL IS 'TIME (DAYS)'

Y-AXES LABEL IS 'LEACH RATE'

CURVE 1

LABEL $=85-18{ }^{125} \mathrm{Sb}$
SYMBOL $=$ OPEN SQUARE

\begin{tabular}{cc}
$X$ & $y$ \\
COORDINATE & COORDINATE \\
\hline
\end{tabular}

1.5E - 04

7. $1 E-05$

3. $4 \mathrm{E}-05$

2. $4 \mathrm{E}-05$

2. $2 \mathrm{E}-05$

2. $0 \mathrm{E}-05$

1. $7 \mathrm{E}-05$

1. $4 \mathrm{E}-05$

$1.1 E-05$

9. $2 E-06$

8. $4 \mathrm{E}-06$

$7.8 \mathrm{E}-06$

$6.8 \mathrm{E}-06$

5. $5 \mathrm{E}-06$

4. $9 \mathrm{E}-06$

4. $8 \mathrm{E}-06$

4. $8 \mathrm{E}-06$

4. $8 \mathrm{E}-06$

4. $1 \mathrm{E}-06$

3. $0 \mathrm{E}-06$

2. $4 \mathrm{E}-06$

1. $7 \mathrm{E}-06$

1. $0 \mathrm{E}-06$

278

6. $4 \mathrm{E}-07$
CURVE 2

LABEL $=85-200^{125}$ Sb
SYMBOL $=$ FILLEO CIRCLE

\begin{tabular}{cc}
$X$ & $Y$ \\
COOROINATE & COORDINATE \\
\hline
\end{tabular}

1. $7 \mathrm{E}-05$

1. $6 \mathrm{E}-05$

1. $2 E-05$

8. $6 \mathrm{E}-06$

6. $2 \mathrm{E}-06$

4. $4 \mathrm{E}-06$

3. $0 E-06$

2. $3 \mathrm{E}-06$

1. $8 E-06$

1. $5 \mathrm{E}-06$

1. $4 E-06$

1. $3 E-06$

1. $3 E-06$

1. $4 \mathrm{E}-06$

1. $3 \mathrm{E}-06$

1. $1 \mathrm{E}-06$

7. $7 \mathrm{E}-07$

6. $3 \mathrm{E}-07$

$6.3 \mathrm{E}-07$

6. $5 E-07$

6. $9 E-07$

7. $0 \mathrm{E}-07$

7. $0 E-07$ 
REFERENCE: MITCHELL, GOODE AND VAUGHEN 1981, p. 21 (contd)

CURVE 3

LABEL $=100-18{ }^{125} \mathrm{Sb}$
SYMBOL $=$ OPEN CIRCLE

$X \quad Y$

\begin{tabular}{|c|c|}
\hline COORDINATE & COORDINATE \\
\hline 0 & $1.9 \mathrm{E}-04$ \\
\hline 2 & 5. $4 \mathrm{E}-05$ \\
\hline 3 & 3. $2 \mathrm{E}-05$ \\
\hline 4 & 2. $3 \mathrm{E}-05$ \\
\hline 5 & $1.7 E-05$ \\
\hline 7 & $1.8 E-05$ \\
\hline 9 & $1.8 \mathrm{E}-05$ \\
\hline 11 & $1.6 \mathrm{E}-05$ \\
\hline 14 & 1. $1 \mathrm{E}-05$ \\
\hline 16 & 8.7E-06 \\
\hline 18 & $6.6 \mathrm{E}-06$ \\
\hline 20 & $5.9 E-06$ \\
\hline 22 & $5.4 \mathrm{E}-06$ \\
\hline 25 & $4.6 \mathrm{E}-06$ \\
\hline 29 & 3. $4 \mathrm{E}-06$ \\
\hline 33 & 2. $1 \mathrm{E}-06$ \\
\hline 40 & $1.4 E-06$ \\
\hline 47 & $1.0 \mathrm{E}-06$ \\
\hline 57 & $6.3 E-07$ \\
\hline 74 & 5.1E-07 \\
\hline 99 & $5.0 E-07$ \\
\hline 128 & $5.5 E-07$ \\
\hline 162 & $6.2 \mathrm{E}-07$ \\
\hline 210 & $6.6 \mathrm{E}-07$ \\
\hline 277 & $6.7 \mathrm{E}-07$ \\
\hline
\end{tabular}

CURVE 4

$\angle A B E L=100-200{ }^{125}$ Sb

SYMBOL = FILLED SQUARE

\begin{tabular}{cc}
$x$ & $y$ \\
COORDINATE & COOROINATE \\
\hline
\end{tabular}

$0 \quad 4.6 \mathrm{E}-05$

$2 \quad 2.5 \mathrm{E}-05$

$7 \quad 1.0 \mathrm{E}-05$

$9 \quad 9.5 \mathrm{E}-06$

$11 \quad 7.2 \mathrm{E}-06$

$13 \quad 4.8 \mathrm{E}-06$

$15 \quad 4.0 \mathrm{E}-06$

$18 \quad 4.0 \mathrm{E}-06$

$20 \quad 3.9 \mathrm{E}-06$

$23 \quad 3.5 \mathrm{E}-06$

$25 \quad 2.7 \mathrm{E}-06$

$27 \quad 1.9 \mathrm{E}-06$

$33 \quad 1.1 \mathrm{E}-06$

$39 \quad 8.7 \mathrm{E}-07$

$46 \quad 7.7 \mathrm{E}-07$

$57 \quad 5.2 \mathrm{E}-07$

$74 \quad 2.7 \mathrm{E}-07$

$99 \quad 2.0 \mathrm{E}-07$

$128 \quad 2.0 \mathrm{E}-07$

$162 \quad 2.0 \mathrm{E}-07$

$210 \quad 2.0 \mathrm{E}-07$

$278 \quad 2.0 \mathrm{E}-07$

DRAWING N0. = ORNL-DWG-80-1452 
REFERENCE: MITCHELL, GOODE AND VAUGHEN 1981, 0. 22

FIGURE TITLE: 'LEACH RATES FOR ${ }^{106}$ Ru'

$X$-AXES LABEL IS 'TIME (DAYS)'

CURVE 1

$\begin{array}{ll}\text { LABEL }=85-18 & 106_{\text {Ru }} \\ \text { SYMBOL }=\text { OPEN SQUARE }\end{array}$

$\begin{array}{ccc}\begin{array}{cc}X \\ \text { COORDINATE }\end{array} & & \begin{array}{c}Y \\ \text { COORDINATE }\end{array} \\ 4 & & 4.0 \mathrm{E}-06 \\ 6 & & 3.1 \mathrm{E}-06 \\ 8 & & 1.9 \mathrm{E}-06 \\ 11 & & 7.7 \mathrm{E}-07 \\ 12 & & 5.3 \mathrm{E}-07 \\ 15 & & 3.7 \mathrm{E}-07 \\ 18 & & 1.4 \mathrm{E}-07 \\ 22 & & 1.0 \mathrm{E}-07 \\ 25 & & 9.3 \mathrm{E}-08 \\ 26 & & 9.0 \mathrm{E}-08 \\ 30 & & 8.3 \mathrm{E}-08 \\ 35 & & 6.8 \mathrm{E}-08\end{array}$

$Y$-AXES LABEL IS 'LEACH RATE'

CURVE 2

LABEL $=85-200{ }^{106} 6_{\mathrm{RU}}$
SYMBOL $=$ FILLED CIRCLE

\begin{tabular}{|c|c|}
\hline $\begin{array}{c}X \\
\text { COOROINATE }\end{array}$ & $\begin{array}{c}y \\
\text { COORDINATE }\end{array}$ \\
\hline $\begin{array}{r}4 \\
6 \\
8 \\
10 \\
11 \\
12 \\
15 \\
18 \\
20 \\
21 \\
25 \\
26 \\
30 \\
35 \\
42 \\
49 \\
58 \\
75 \\
100 \\
129 \\
162 \\
210 \\
277\end{array}$ & $\begin{array}{l}6.7 \mathrm{E}-07 \\
6.3 \mathrm{E}-07 \\
5.0 \mathrm{E}-07 \\
3.3 \mathrm{E}-07 \\
1.9 \mathrm{E}-07 \\
1.0 \mathrm{E}-07 \\
5.2 \mathrm{E}-08 \\
2.7 \mathrm{E}-08 \\
2.0 \mathrm{E}-08 \\
2.0 \mathrm{E}-08 \\
2.4 \mathrm{E}-08 \\
3.1 \mathrm{E}-08 \\
3.6 \mathrm{E}-08 \\
3.5 \mathrm{E}-08 \\
3.3 \mathrm{E}-08 \\
2.7 \mathrm{E}-08 \\
2.0 \mathrm{E}-08 \\
1.8 \mathrm{E}-\mathrm{D} 8 \\
1.8 \mathrm{E}-08 \\
1.9 \mathrm{E}-08 \\
2.2 \mathrm{E}-08 \\
2.3 \mathrm{E}-08 \\
2.3 \mathrm{E}-08\end{array}$ \\
\hline
\end{tabular}


REFERENCE: MITCHELL, GOODE AND VAUGHEN 1981, p. 22 (contd)

CURVE 3

LABEL $=100-18^{106}{ }_{\text {Ru }}$
SYMBOL $=$ OPEN CIRCLE

\begin{tabular}{ccc}
$\begin{array}{c}X \\
\text { COORDINATE }\end{array}$ & & $\begin{array}{c}Y \\
\text { COORDINATE }\end{array}$ \\
\cline { 1 - 1 } 2 & & $7.3 \mathrm{E}-06$ \\
6 & & $3.4 \mathrm{E}-06$ \\
8 & & $1.54 \mathrm{E}-06$ \\
10 & & $1.0 \mathrm{E}-06$ \\
11 & & $7.5 \mathrm{E}-07$ \\
12 & & $5.1 \mathrm{E}-07$ \\
15 & & $3.0 \mathrm{E}-07$ \\
17 & & $2.4 \mathrm{E}-07$ \\
20 & & $1.6 \mathrm{E}-07$ \\
22 & & $1.6 \mathrm{E}-07$ \\
25 & & $1.5 \mathrm{E}-07$ \\
26 & & $1.2 \mathrm{E}-07$ \\
29 & & $6.0 \mathrm{E}-08$ \\
34 & $3.4 \mathrm{E}-08$ \\
40 & $3.1 \mathrm{E}-08$ \\
52 & $2.7 \mathrm{E}-08$ \\
72 & $2.0 \mathrm{E}-08$ \\
100 & $1.7 \mathrm{E}-08$ \\
130 & $1.7 \mathrm{E}-08$
\end{tabular}

CURVE 4

LABEL $=100-200{ }^{106}$ Ru
SYMBOL $=$ FILLED SQUARE

\begin{tabular}{cc}
$X$ & $y$ \\
COORDINATE & CDORDINATE \\
\hline
\end{tabular}

1. $2 \mathrm{E}-06$

1. $2 \mathrm{E}-06$

8. $8 \mathrm{E}-07$

4. $7 \mathrm{E}-07$

2. $9 \mathrm{E}-07$

2. 5E -07

2. $5 \mathrm{E}-07$

2. $9 \mathrm{E}-07$

2. 5E -07

1. $4 \mathrm{E}-07$

7. $8 \mathrm{E}-08$

$6.1 \mathrm{E}-08$

6. $6 \mathrm{E}-08$

3. $7 \mathrm{E}-08$

1. $1 \mathrm{E}-08$

6. $0 \mathrm{E}-09$

6. $1 \mathrm{E}-09$

DRAWING NO. = ORNL-DWG-B0-1469 
REFERENCE: MITCHELL, GOODE AND VAUGHEN 1981, p. 23

FIGURE TITLE: 'LEACH RATES FOR ${ }^{90}{ } r^{\prime}$ '

X-AXES LABEL IS 'TIME (DAYS)'

CURVE 1

LABEL $=85-1890$ Sr
SYMBOL $=$ OPEN SQUARE
$X$
COORDINATE COORDINATE

$\begin{array}{rr}1 & 6.3 \mathrm{E}-06 \\ 3 & 4.1 \mathrm{E}-06 \\ 5 & 2.6 \mathrm{E}-06 \\ 9 & 1.7 \mathrm{E}-06 \\ 12 & 1.3 \mathrm{E}-06 \\ 17 & 1.0 \mathrm{E}-06 \\ 25 & 4.8 \mathrm{E}-07 \\ 38 & 1.9 \mathrm{E}-07 \\ 54 & 9.7 \mathrm{E}-08 \\ 73 & 5.1 \mathrm{E}-08 \\ 100 & 2.7 \mathrm{E}-08 \\ 129 & 2.0 \mathrm{E}-08 \\ 169 & 1.7 \mathrm{E}-08 \\ 226 & 1.5 \mathrm{E}-08\end{array}$

Y-AXES LABEL IS 'LEACH RATE'

CURVE 2

LABEL $=85-20090_{\text {Sr }}$
SYMBOL $=$ FILLED CIRCLE

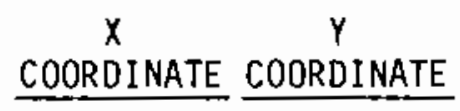

$\begin{array}{rr}1 & 2.1 \mathrm{E}-07 \\ 3 & 2.0 \mathrm{E}-07 \\ 7 & 1.6 \mathrm{E}-07 \\ 12 & 1.4 \mathrm{E}-07 \\ 17 & 9.4 \mathrm{E}-08 \\ 25 & 4.2 \mathrm{E}-08 \\ 38 & 2.4 \mathrm{E}-08 \\ 54 & 1.8 \mathrm{E}-08 \\ 73 & 1.1 \mathrm{E}-08 \\ 100 & 5.7 \mathrm{E}-09 \\ 129 & 4.2 \mathrm{E}-09 \\ 169 & 4.2 \mathrm{E}-09 \\ 226 & 4.3 \mathrm{E}-09\end{array}$

CURVE 3

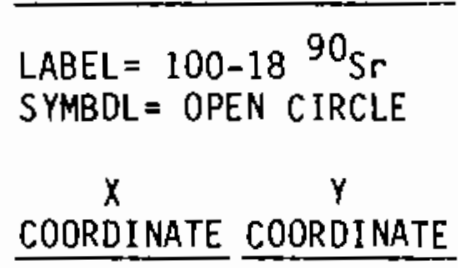

COORDINATE COORDINATE

$\begin{array}{rr}1 & 4.1 \mathrm{E}-06 \\ 3 & 3.5 \mathrm{E}-06 \\ 6 & 2.3 \mathrm{E}-06 \\ 7 & 1.3 \mathrm{E}-06 \\ 10 & 9.5 \mathrm{E}-07 \\ 12 & 7.6 \mathrm{E}-07 \\ 17 & 4.6 \mathrm{E}-07 \\ 25 & 3.2 \mathrm{E}-07 \\ 38 & 2.9 \mathrm{E}-07 \\ 54 & 2.9 \mathrm{E}-07 \\ 73 & 1.6 \mathrm{E}-07 \\ 100 & 5.4 \mathrm{E}-08 \\ 129 & 2.8 \mathrm{E}-08 \\ 169 & 2.7 \mathrm{E}-08 \\ 226 & 2.7 \mathrm{E}-08\end{array}$

CURVE 4

LABEL $=100-20090_{S r}$
SYMBOL = FILLED SQUARE

\begin{tabular}{|c|c|c|c|}
\hline $\begin{array}{c}x \\
\text { COORDINATE } \\
\end{array}$ & $\begin{array}{c}Y \\
\text { COORDINATE } \\
\end{array}$ & $\begin{array}{c}x \\
\text { COORDINATE } \\
\end{array}$ & $\begin{array}{c}y \\
\text { COORDINATE }\end{array}$ \\
\hline 0 & 4.2E -07 & 38 & 2.5E-08 \\
\hline 3 & $4.2 \mathrm{E}-07$ & 54 & $1.2 E-08$ \\
\hline 6 & 4. $2 \mathrm{E}-07$ & 73 & $8.3 \mathrm{E}-09$ \\
\hline 7 & 3. $3 E-07$ & 100 & 8.1E-09 \\
\hline 10 & $1.8 \mathrm{E}-07$ & 129 & 8.1E-09 \\
\hline 13 & $1.1 \mathrm{E}-07$ & 169 & $7.2 \mathrm{E}-09$ \\
\hline 17 & $8.4 E-08$ & 226 & $5.9 E-09$ \\
\hline 25 & $5.4 E-D 8$ & & \\
\hline
\end{tabular}

DRAWING NO. = ORNL-DWG-80-1470 
REFERENCE: JOHNSON et al. 1981, p. 23

FIGURE TITLE: 'FRACTIONAL RELEASE OF ${ }^{137}$ CS FROM FUEL DURING $25 \mathrm{C}$ LEACHING PERIOD'

$X$-AXES LABEL IS 'TIME (DAYS)'

CURVE 1

LABEL = RUN \#1

SYMBOL = OPEN SQUARE

\begin{tabular}{|c|c|}
\hline $\begin{array}{c}x \\
\text { COORDINATE } \\
\end{array}$ & $\begin{array}{c}Y \\
\text { COORDINATE }\end{array}$ \\
\hline $\begin{array}{r}9 \\
22 \\
39 \\
59 \\
72 \\
92\end{array}$ & $\begin{array}{l}1.3 E-04 \\
8.2 E-06 \\
6.2 E-06 \\
3.4 E-06 \\
2.1 E-06 \\
1.6 E-06\end{array}$ \\
\hline
\end{tabular}

CURVE 3

LABEL $=$ RUN \#4

SYMBOL = OPEN TRIANGLE

\begin{tabular}{|c|c|}
\hline $\begin{array}{c}x \\
\text { COORDINATE }\end{array}$ & $\begin{array}{c}Y \\
\text { COOROINATE }\end{array}$ \\
\hline & $2.5 E-04$ \\
\hline 0 & 7. $3 \mathrm{E}-05$ \\
\hline 15 & $1.7 \mathrm{E}-05$ \\
\hline 29 & $5.4 E-06$ \\
\hline 59 & 3.0E -06 \\
\hline 88 & 1.7E-06 \\
\hline 110 & $6.1 E-07$ \\
\hline
\end{tabular}

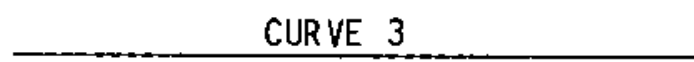

$Y$-AXES LABEL IS 'FRACTIONAL RELEASE RATE (1/DAYS)'

CURVE 2

\section{$\mathrm{LABEL}=\mathrm{RUN} \# 3$}

SYMBOL = INVERTED TR IANGLE

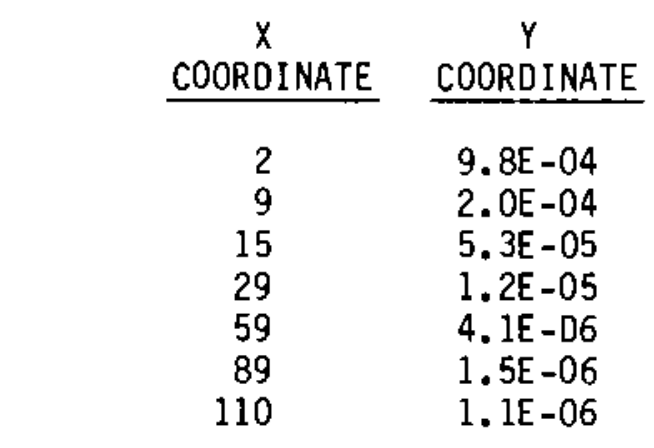

\begin{tabular}{|c|c|}
\hline \multicolumn{2}{|c|}{ CURVE 4} \\
\hline \multicolumn{2}{|c|}{$\begin{array}{l}\text { LABEL }=\text { RUN } \# 5 \\
\text { SYMBDL }=\text { DPEN CIRCLE }\end{array}$} \\
\hline $\begin{array}{c}x \\
\text { COORDINATE } \\
\end{array}$ & $\begin{array}{c}y \\
\text { COORDINATE }\end{array}$ \\
\hline $\begin{array}{r}2 \\
8 \\
16 \\
29 \\
59 \\
89 \\
120\end{array}$ & $\begin{array}{l}2.7 \mathrm{E}-03 \\
3.6 \mathrm{E}-04 \\
8.6 \mathrm{E}-05 \\
1.8 \mathrm{E}-05 \\
5.4 \mathrm{E}-06 \\
2.2 \mathrm{E}-06 \\
1.5 \mathrm{E}-06\end{array}$ \\
\hline
\end{tabular}


REFERENCE: JOHNSON 1982, p. 18

FIGURE TITLE: 'FRACTIONAL RELEASE RATES OF RADIONUCLIDES IN DEIONIZEO OISTILLED WATER (LEACHANT A)'

$X$-AXES LABEL IS 'TIME (DAYS)'
$Y$-AXES LABEL IS 'FRACTIONAL RELEASE RATE (1/DAYS)'
CURVE 1

$\begin{aligned} & \text { LABEL }={ }^{137} \mathrm{CS} \\ & \text { SYMBOL }=\text { OPEN } \\ & \text { TR IANGLE } \\ & \times Y \\ & \text { COOROINATE COORDINATE }\end{aligned}$

COORDINATE COORDINATE

$\begin{array}{rr}3 & 9.9 E-04 \\ 6 & 3.0 E-04 \\ 9 & 1.1 \mathrm{E}-04 \\ 15 & 1.5 \mathrm{E}-05 \\ 17 & 6.4 \mathrm{E}-06 \\ 29 & 5.7 \mathrm{E}-06 \\ 35 & 4.6 \mathrm{E}-06 \\ 43 & 4.0 \mathrm{E}-06 \\ 54 & 2.2 \mathrm{E}-06 \\ 84 & 1.2 \mathrm{E}-06 \\ 114 & 1.1 \mathrm{E}-06 \\ 148 & 9.5 \mathrm{E}-07 \\ 181 & 8.2 \mathrm{E}-07 \\ 207 & 9.0 \mathrm{E}-07 \\ 274 & 3.2 \mathrm{E}-07 \\ 335 & 4.0 \mathrm{E}-07 \\ 398 & 4.4 \mathrm{E}-07 \\ 459 & 4.8 \mathrm{E}-07 \\ 516 & 4.7 \mathrm{E}-07 \\ 579 & 3.6 \mathrm{E}-07 \\ 666 & 2.1 \mathrm{E}-07 \\ 779 & 3.1 \mathrm{E}-07 \\ 809 & 5.5 \mathrm{E}-07 \\ 820 & 1.2 \mathrm{E}-06 \\ 911 & 5.0 \mathrm{E}-07\end{array}$

CURVE 2

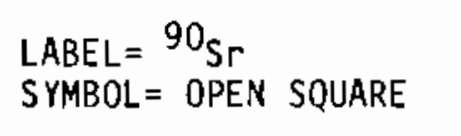

\begin{tabular}{cc}
$x$ & $y$ \\
COORDINATE & COORDINATE \\
\hline
\end{tabular}

$8.0 \mathrm{E}-06$

9.2E-D6

7. $6 \mathrm{E}-06$

$6.5 \mathrm{E}-06$

5. $5 \mathrm{E}-06$

4. $9 \mathrm{E}-\mathrm{D} 6$

4. $0 \mathrm{E}-06$

3. $4 \mathrm{E}-06$

3. $3 \mathrm{E}-06$

2. $8 \mathrm{E}-06$

1. $6 \mathrm{E}-06$

1. $6 \mathrm{E}-06$

1. $5 E-06$

1. $1 E-D 6$

6. $5 \mathrm{E}-07$

3. $9 \mathrm{E}-07$

2. $6 \mathrm{E}-07$

$1.6 \mathrm{E}-07$

9. $3 \mathrm{E}-08$

8. $5 \mathrm{E}-08$

8. $5 E-D 8$

2. $9 \mathrm{E}-08$

2. $0 E-08$

1. $7 \mathrm{E}-08$

4. $5 \mathrm{E}-08$

779

817

820
CURVE 3

$\angle A B E L=U$

SYMBOL = OPEN CIRCLE

$\stackrel{x}{\text { COOROINATE COORDINATE }}$

181

214

275

337

395

458

517

579

673

783

812

823
1. $7 \mathrm{E}-09$

$1.3 \mathrm{E}-09$

9. $0 E-10$

2. $9 \mathrm{E}-09$

1. $0 \mathrm{E}-09$

2. 0 E -09

$1.8 \mathrm{E}-09$

1. $1 \mathrm{E}-09$

7. $7 E-10$

1. $0 E-09$

4. $2 \mathrm{E}-10$

1. $0 E-08$ 
REFERENCE: JOHNSON 1982, p. 18 (contd)

CURVE 4

\begin{tabular}{|c|c|}
\hline $\begin{array}{l}\mathrm{LABEL}={ }^{99} \mathrm{TC} \\
S Y M B O L=X\end{array}$ & \\
\hline $\begin{array}{c}x \\
\text { COORDINATE } \\
\end{array}$ & $\begin{array}{c}Y \\
\text { COORDINATE }\end{array}$ \\
\hline $\begin{array}{l}578 \\
669 \\
815 \\
821\end{array}$ & $\begin{array}{l}1.0 E-07 \\
4.7 E-08 \\
8.8 E-08 \\
2.1 E-07\end{array}$ \\
\hline
\end{tabular}

CURVE 5

LABEL $=239+240 \mathrm{PU}$
SYMBOL $=$ FILLED CIRCLE

$X \quad Y$ COORDINATE COORDINATE

1. $5 \mathrm{E} \rightarrow 06$

5. $1 \mathrm{E}-07$

$5.8 E-07$

$5.1 \mathrm{E}-07$

4. $8 \mathrm{E}-07$

5.7E-07

3. $4 \mathrm{E}-07$

3. $5 \mathrm{E}-07$

3. $6 \mathrm{E}-08$

$3.5 \mathrm{E}-08$

6. $5 \mathrm{E}-08$

4. $3 \mathrm{E}-08$

$6.3 \mathrm{E}-08$

9. $5 \mathrm{E}-09$

1. $7 \mathrm{E}-08$

2. $1 \mathrm{E}-08$

3. $2 \mathrm{E}-08$

2. $4 \mathrm{E}-08$

1. $4 \mathrm{E}-08$

1. $0 E-08$

1. $6 \mathrm{E}-08$

1. $3 \mathrm{E}-08$

3. $8 \mathrm{E}-08$ 
REFERENCE : JOHNSON 1982, ค. 19

FIGURE TITLE: 'FRACTIONAL RELEASE RATES OF RADIONUCLIOES IN KBS GROUNDWATER (LEACHANT B)'

$X$-AXES LABEL IS 'TIME (DAYS)'

Y-AXES LABEL IS 'FRACTIONAL RELEASE RATE (1/OAYS)'

CURVE 1

LABEL $={ }^{137}$ CS
SYMBOL $=$ OPEN TRIANGLE
X
COOROINATE COOROINATE

$\angle A B E L={ }^{137} \mathrm{Cs}$

INATE

$\begin{array}{rr}0 & 9.6 \mathrm{E}-04 \\ 0 & 2.3 \mathrm{E}-04 \\ 4 & 4.3 \mathrm{E}-05 \\ 13 & 1.5 \mathrm{E}-05 \\ 22 & 7.6 \mathrm{E}-06 \\ 25 & 6.0 \mathrm{E}-06 \\ 33 & 6.6 \mathrm{E}-06 \\ 83 & 3.7 \mathrm{E}-06 \\ 114 & 3.2 \mathrm{E}-06 \\ 181 & 1.6 \mathrm{E}-06 \\ 212 & 8.9 \mathrm{E}-07 \\ 277 & 4.6 \mathrm{E}-07 \\ 332 & 6.7 \mathrm{E}-07 \\ 404 & 3.2 \mathrm{E}-07 \\ 461 & 3.6 \mathrm{E}-07 \\ 524 & 8.3 \mathrm{E}-07 \\ 584 & 5.4 \mathrm{E}-07 \\ 676 & 1.9 \mathrm{E}-07 \\ 787 & 2.8 \mathrm{E}-07 \\ 818 & 2.8 \mathrm{E}-07 \\ 824 & 2.3 \mathrm{E}-07 \\ 919 & 2.5 \mathrm{E}-07\end{array}$

CURVE 2

$\angle A B E L={ }^{90} \mathrm{Sr}$

SYMBOL = OPEN SQUARE

\begin{tabular}{cc}
$X$ & $y$ \\
COOROINATE & COORDINATE \\
\hline
\end{tabular}

7. $1 \mathrm{E}-06$

3. $3 E-06$

2. $3 E-06$

1. $2 \mathrm{E}-06$

9.7E-07

8. $3 E-07$

5. $5 E-07$

5. 5E -07

$3,8 \mathrm{E}-07$

3. $6 \mathrm{E}-\mathrm{D} 7$

2. $6 \mathrm{E}-07$

2. $7 \mathrm{E}-07$

1. $2 \mathrm{E}-07$

8. $3 E-08$

$9.5 E-08$

7. $8 \mathrm{E}-08$

9. $1 \mathrm{E}-08$

3. $6 \mathrm{E}-07$

2. $4 \mathrm{E}-07$

$6.4 \mathrm{E}-08$

9. $3 E-08$

9. $6 \mathrm{E}-08$

1. $2 \mathrm{E}-07$
CURVE 3

LABEL = URANIUM

SYMBOL = OPEN CIRCLE

\begin{tabular}{cc}
$X$ & $y$ \\
COOROINATE & COORDINATE \\
\hline
\end{tabular}

184

218

277

335

402

464

522

588

676

789

818

826
9. $2 \mathrm{E}-08$

$6.8 \mathrm{E}-08$

7. 0 E -08

7. $7 \mathrm{E}-08$

6. $3 \mathrm{E}-08$

7. $6 \mathrm{E}-08$

4. $1 \mathrm{E}-07$

6. $9 E-08$

5. $4 E-08$

1. 7E-08

3. $9 \mathrm{E}-08$

4. $4 \mathrm{E}-08$ 
REFERENCE: JOHNSON 1982, p. 19 (contd)

CURVE 4

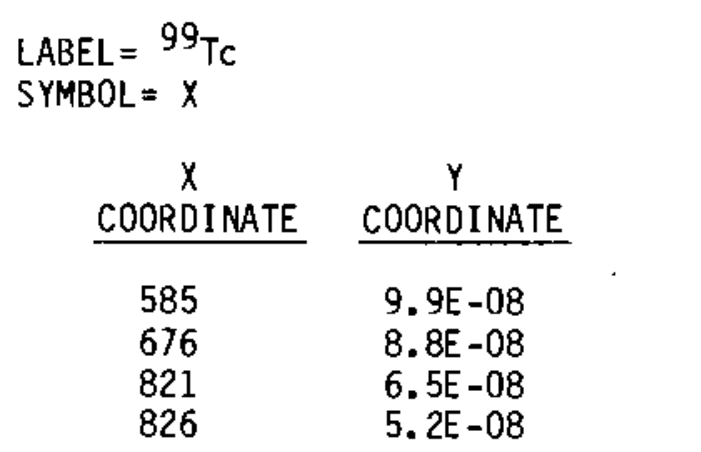

CURVE 5

\begin{tabular}{cc} 
LABEL $=$ & $239+240 \mathrm{Pu}$ \\
SYMBOL $=$ & \\
$X$ & \\
COORDINATE & COORDINATE \\
\cline { 2 - 3 } 2 & $1.1 \mathrm{E}-06$ \\
5 & $1.2 \mathrm{E}-07$ \\
7 & $3.1 \mathrm{E}-07$ \\
17 & $6.7 \mathrm{E}-08$ \\
22 & $7.4 \mathrm{E}-08$ \\
30 & $4.8 \mathrm{E}-08$ \\
34 & $3.5 \mathrm{E}-07$ \\
45 & $2.7 \mathrm{E}-08$ \\
57 & $1.1 \mathrm{E}-07$ \\
89 & $5.9 \mathrm{E}-08$ \\
117 & $3.5 \mathrm{E}-08$ \\
154 & $3.3 \mathrm{E}-08$ \\
186 & $3.7 \mathrm{E}-08$ \\
217 & $5.5 \mathrm{E}-08$ \\
335 & $2.0 \mathrm{E}-08$ \\
402 & $2.8 \mathrm{E}-08$ \\
464 & $7.5 \mathrm{E}-09$ \\
524 & $5.2 \mathrm{E}-08$ \\
586 & $6.1 \mathrm{E}-09$ \\
678 & $3.2 \mathrm{E}-09$ \\
789 & $3.1 \mathrm{E}-09$
\end{tabular}


REFERENCE: JOHNSON 1982, p. 20

FIGURE TITLE: 'FRACTIONAL RELEASE RATES OF RADIONUCLIOES IN GRANITE GROUNDWATER (LEACHANT C)'

$X$-AXES LABEL IS 'TIME (DAYS)'

CURVE 1

LABEL $={ }^{137} \mathrm{CS}$
SYMBOL $=$ OPEN TRIANGLE

\begin{tabular}{cc}
$X$ & $Y$ \\
COOROINATE & COORDINATE \\
\hline
\end{tabular}

$\begin{array}{rr}0 & 4.5 \mathrm{E}-04 \\ 2 & 1.6 \mathrm{E}-04 \\ 5 & 6.9 \mathrm{E}-05 \\ 13 & 1.5 \mathrm{E}-05 \\ 21 & 3.7 \mathrm{E}-06 \\ 26 & 2.9 \mathrm{E}-06 \\ 35 & 2.5 \mathrm{E}-06 \\ 43 & 1.8 \mathrm{E}-06 \\ 55 & 1.7 \mathrm{E}-06 \\ 83 & 1.3 \mathrm{E}-06 \\ 116 & 9.5 \mathrm{E}-07 \\ 181 & 8.6 \mathrm{E}-07 \\ 217 & 3.6 \mathrm{E}-07 \\ 276 & 5.3 \mathrm{E}-07 \\ 338 & 6.6 \mathrm{E}-07 \\ 401 & 5.1 \mathrm{E}-07 \\ 461 & 4.7 \mathrm{E}-07 \\ 523 & 5.3 \mathrm{E}-07 \\ 583 & 3.8 \mathrm{E}-07 \\ 672 & 2.8 \mathrm{E}-07 \\ 784 & 3.2 \mathrm{E}-07 \\ 816 & 2.7 \mathrm{E}-07 \\ 821 & 2.8 \mathrm{E}-07 \\ 914 & 3.3 \mathrm{E}-07\end{array}$

$Y$-AXES LABEL IS 'FRACTIONAL RELEASE
RATE (1/OAYS)'

CURVE 2

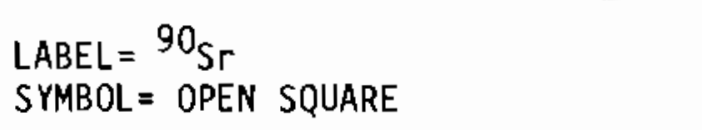

\begin{tabular}{cc}
$X$ & $y$ \\
COORDINATE & COORDINATE \\
\hline
\end{tabular}

$\begin{array}{rr}0 & 9.1 \mathrm{E}-06 \\ 2 & 5.7 \mathrm{E}-06 \\ 5 & 4.8 \mathrm{E}-06 \\ 12 & 3.7 \mathrm{E}-06 \\ 20 & 2.4 \mathrm{E}-06 \\ 29 & 2.5 \mathrm{E}-06 \\ 29 & 2.0 \mathrm{E}-06 \\ 38 & 1.6 \mathrm{E}-06 \\ 43 & 1.3 \mathrm{E}-06 \\ 56 & 1.2 \mathrm{E}-06 \\ 87 & 9.3 \mathrm{E}-07 \\ 116 & 6.5 \mathrm{E}-07 \\ 151 & 4.8 \mathrm{E}-07 \\ 186 & 3.8 \mathrm{E}-07 \\ 217 & 2.0 \mathrm{E}-07 \\ 278 & 1.5 \mathrm{E}-07 \\ 339 & 2.3 \mathrm{E}-07 \\ 402 & 1.7 \mathrm{E}-07 \\ 462 & 1.5 \mathrm{E}-07 \\ 525 & 1.8 \mathrm{E}-07 \\ 583 & 1.1 \mathrm{E}-07 \\ 675 & 9.3 \mathrm{E}-08 \\ 784 & 1.2 \mathrm{E}-07 \\ 815 & 1.3 \mathrm{E}-07 \\ 825 & 1.6 \mathrm{E}-07\end{array}$


REFERENCE: JOHNSON 1982, p. 20 (contd)

\begin{tabular}{|c|c|c|c|c|c|}
\hline \multicolumn{2}{|c|}{ CURVE 3} & \multicolumn{2}{|c|}{ CURVE 4} & \multicolumn{2}{|c|}{ CURVE 5} \\
\hline $\begin{array}{l}\text { LABEL }=\text { URA } \\
\text { SYMBOL }=0 P\end{array}$ & $\begin{array}{l}\text { NIUM } \\
\text { EN CIRCLE }\end{array}$ & $\begin{array}{l}\angle A B E L={ }^{99} T \\
\text { SYMBOL }=x\end{array}$ & & $\begin{array}{l}\angle A B E L=239 \\
\text { SYMBOL }=F I\end{array}$ & $\begin{array}{l}+240 \mathrm{PU} \\
\text { LLED CIRCLE }\end{array}$ \\
\hline $\begin{array}{c}x \\
\text { COORDINATE }\end{array}$ & $\begin{array}{c}Y \\
\text { COORDINATE }\end{array}$ & $\begin{array}{c}x \\
\text { COORDINATE }\end{array}$ & $\begin{array}{c}Y \\
\text { COORDINATE }\end{array}$ & $\begin{array}{c}x \\
\text { COORDINATE }\end{array}$ & $\begin{array}{c}Y \\
\text { COORDINATE }\end{array}$ \\
\hline $\begin{array}{l}182 \\
214 \\
278 \\
334 \\
397 \\
461 \\
524 \\
583 \\
671 \\
786 \\
820 \\
826\end{array}$ & $\begin{array}{l}9.5 \mathrm{E}-08 \\
4.7 \mathrm{E}-08 \\
3.6 \mathrm{E}-08 \\
4.0 \mathrm{E}-08 \\
2.9 \mathrm{E}-08 \\
3.1 \mathrm{E}-08 \\
5.5 \mathrm{E}-08 \\
2.2 \mathrm{E}-08 \\
3.9 \mathrm{E}-08 \\
5.7 \mathrm{E}-09 \\
1.4 \mathrm{E}-08 \\
4.4 \mathrm{E}-08\end{array}$ & $\begin{array}{l}581 \\
674 \\
814 \\
824\end{array}$ & $\begin{array}{l}2.5 \mathrm{E}-07 \\
1.2 \mathrm{E}-07 \\
1.6 \mathrm{E}-07 \\
3.3 \mathrm{E}-08\end{array}$ & $\begin{array}{r}D \\
5 \\
7 \\
13 \\
18 \\
26 \\
35 \\
42 \\
57 \\
87 \\
115 \\
151 \\
186 \\
218 \\
276 \\
336 \\
402 \\
461 \\
524 \\
584 \\
675 \\
786 \\
818\end{array}$ & $\begin{array}{l}1.5 \mathrm{E}-06 \\
1.5 \mathrm{E}-07 \\
2.4 \mathrm{E}-07 \\
1.8 \mathrm{E}-07 \\
9.5 \mathrm{E}-08 \\
8.8 \mathrm{E}-08 \\
1.2 \mathrm{E}-07 \\
8.7 \mathrm{E}-08 \\
8.2 \mathrm{E}-\mathrm{D} \\
3.7 \mathrm{E}-08 \\
2.1 \mathrm{E}-08 \\
1.7 \mathrm{E}-08 \\
3.5 \mathrm{E}-08 \\
1.8 \mathrm{E}-08 \\
6.0 \mathrm{E}-09 \\
1.4 \mathrm{E}-08 \\
6.1 \mathrm{E}-09 \\
1.1 \mathrm{E}-08 \\
1.2 \mathrm{E}-08 \\
8.2 \mathrm{E}-09 \\
9.7 \mathrm{E}-09 \\
4.2 \mathrm{E}-09 \\
1.0 \mathrm{E}-08\end{array}$ \\
\hline
\end{tabular}


REFERENCE: JOHNSON 1982, p. 21

FIGURE TITLE: 'FRACTIONAL RELEASE RATES OF RADIONUCLIDES IN STANDARD CANADIAN SHIELD SALINE SOLUTION (LEACHANT D)'

$X$-AXES LABEL IS 'TIME (DAYS)'

CURVE 1

LABEL $={ }^{137}$ CS
SYMBOL $=$ OPEN TRIANGLE

\begin{tabular}{ccc}
$\begin{array}{cc}X \\
\text { COORDINATE }\end{array}$ & & $\begin{array}{c}Y \\
\text { COORDINATE }\end{array}$ \\
\cline { 1 - 1 } 0 & & $2.5 \mathrm{E}-04$ \\
0 & & $8.0 \mathrm{E}-05$ \\
4 & & $4.3 \mathrm{E}-05$ \\
13 & & $1.1 \mathrm{E}-05$ \\
19 & & $3.1 \mathrm{E}-06$ \\
28 & & $1.7 \mathrm{E}-06$ \\
32 & & $1.3 \mathrm{E}-06$ \\
41 & & $1.2 \mathrm{E}-06$ \\
117 & & $7.3 \mathrm{E}-07$ \\
182 & & $8.7 \mathrm{E}-07$ \\
213 & & $8.4 \mathrm{E}-07$ \\
272 & & $8.7 \mathrm{E}-07$ \\
338 & & $1.3 \mathrm{E}-07$ \\
400 & & $2.3 \mathrm{E}-07$ \\
461 & & $1.6 \mathrm{E}-07$ \\
518 & $2.2 \mathrm{E}-07$ \\
580 & $1.9 \mathrm{E}-07$ \\
672 & $5.4 \mathrm{E}-07$ \\
781 & $5.3 \mathrm{E}-07$ \\
817 & $1.3 \mathrm{E}-07$ \\
823 & $1.0 \mathrm{E}-07$ \\
914 & $1.2 \mathrm{E}-07$
\end{tabular}

Y-AXES LABEL IS 'FRACTIONAL RELEASE RATE (1/DAYS)'

CURVE 2

$\angle A B E L={ }^{90} \mathrm{Sr}$

SYMBOL = OPEN SQUARE

$\begin{array}{ccc}\begin{array}{cc}X \\ \text { COORDINATE }\end{array} & & \begin{array}{c}Y \\ \text { COORDINATE }\end{array} \\ 3 & & 7.4 \mathrm{E}-06 \\ 3 & & 3.4 \mathrm{E}-06 \\ 10 & & 2.7 \mathrm{E}-06 \\ 13 & & 2.3 \mathrm{E}-06 \\ 22 & & 2.5 \mathrm{E}-06 \\ 28 & & 2.3 \mathrm{E}-06 \\ 35 & & 1.9 \mathrm{E}-06 \\ 44 & & 1.4 \mathrm{E}-06 \\ 55 & & 1.1 \mathrm{E}-06 \\ 84 & & 5.4 \mathrm{E}-07 \\ 117 & & 4.6 \mathrm{E}-07 \\ 149 & & 6.1 \mathrm{E}-07 \\ 183 & & 2.7 \mathrm{E}-07 \\ 216 & & 3.7 \mathrm{E}-07 \\ 338 & & 3.5 \mathrm{E}-08 \\ 399 & & 2.6 \mathrm{E}-08 \\ 459 & & 5.0 \mathrm{E}-08 \\ 521 & & 8.9 \mathrm{E}-08 \\ 583 & & 1.9 \mathrm{E}-08 \\ 673 & & 1.1 \mathrm{E}-07 \\ 782 & 7.6 \mathrm{E}-08 \\ 816 & 7.4 \mathrm{E}-08 \\ 822 & 5.9 \mathrm{E}-08\end{array}$

CURVE 3

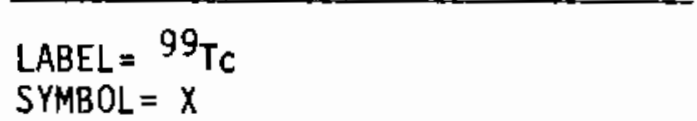

\begin{tabular}{ccc}
$\begin{array}{cc}X \\
\text { COORDINATE }\end{array}$ & & $\begin{array}{c}Y \\
\text { COOROINATE }\end{array}$ \\
\cline { 1 - 1 } 580 & & $3.6 \mathrm{E}-07$ \\
672 & & $2.7 \mathrm{E}-07$ \\
785 & & $1.8 \mathrm{E}-07$ \\
816 & & $1.5 \mathrm{E}-07$ \\
825 & & $9.0 \mathrm{E}-08$
\end{tabular}


REFERENCE : JOHNSON 1982, p. 23

FIGURE TITLE: 'FRACTIONAL RELEASE RATES OF ${ }^{137} \mathrm{CS}$ UNDER CONTROLLED OXYGEN PRESSURE CONDITIONS'

$X$-AXES LABEL IS 'TIME (DAYS)'

CUR VE 1

$\angle A B E L=2.5 E-04$

SYMBOL $=$ OPEN CIRCLE

\begin{tabular}{cc}
$X$ \\
COORDINATE \\
\hline
\end{tabular}

$\begin{array}{rr}0 & 4.4 \mathrm{E}-04 \\ 2 & 1.6 \mathrm{E}-05 \\ 4 & 5.5 \mathrm{E}-06 \\ 11 & 4.7 \mathrm{E}-06 \\ 26 & 1.9 \mathrm{E}-06 \\ 47 & 2.1 \mathrm{E}-06 \\ 75 & 1.7 \mathrm{E}-06 \\ 105 & 1.0 \mathrm{E}-06 \\ 136 & 5.9 \mathrm{E}-07 \\ 167 & 4.2 \mathrm{E}-07 \\ 194 & 2.4 \mathrm{E}-07 \\ 224 & 3.7 \mathrm{E}-07 \\ 253 & 2.5 \mathrm{E}-07 \\ 287 & 2.1 \mathrm{E}-07 \\ 313 & 2.4 \mathrm{E}-07 \\ 346 & 2.6 \mathrm{E}-07 \\ 374 & 2.3 \mathrm{E}-07\end{array}$

Y-AXES LABEL IS 'FRACTIONAL RELEASE

RATE (1/DAYS)'

CURVE 2

$\mathrm{LABEL}=6,1 \mathrm{E}-06$

$S Y M B O L=$ OPEN SQUARE

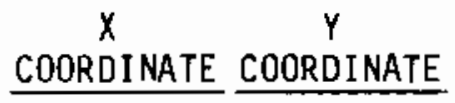

2. $3 E-04$

$1.8 \mathrm{E}-05$

6. $2 \mathrm{E}-06$

1.8E -06

8. $0 \mathrm{E}-07$

9.7E-07

$6.3 E-07$

3.7E-07

2. $5 \mathrm{E}-07$

3. $5 \mathrm{E}-07$

3. $7 \mathrm{E}-07$

3. $0 \mathrm{E}-\mathrm{D} 7$

$2.2 E-07$

1. $2 \mathrm{E}-07$

1. $2 \mathrm{E}-07$

1. $0 \mathrm{E}-07$

7. $5 \mathrm{E}-08$

1. $5 \mathrm{E}-07$

1. $0 \mathrm{E}-07$
CURVE 3

$\mathrm{LABEL}=1 . \mathrm{DE}-06$

SYMBOL = OPEN TRIANGLE

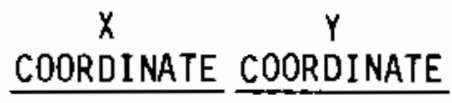

0

3

$3 \quad 3.5 \mathrm{E}-05$

$5 \quad 1.1 \mathrm{E}-05$

10

27

47

77

107

135

166

194

225

255

287

313

346

376

403

434
3. $6 \mathrm{E}-06$

1. $6 \mathrm{E}-06$

4. $1 \mathrm{E}-07$

5. $0 \mathrm{E}-07$

3. $1 E-07$

5. OE -07

3. $1 \mathrm{E}-07$

$2.8 \mathrm{E}-07$

2. $6 \mathrm{E}-07$

3. $3 \mathrm{E}-07$

3. $9 \mathrm{E}-07$

3. $6 \mathrm{E}-07$

2. $1 \mathrm{E}-07$

1. $8 \mathrm{E}-\mathrm{D} 7$

1. $8 \mathrm{E}-07$

1. $9 \mathrm{E}-07$

$[02] \mathrm{mo}]^{*} \mathrm{~kg}$ e-01 
REFERENCE: JOHNSON 1982 , p. 24

FIGURE TITLE: 'FRACTIONAL RELEASE RATES OF ${ }^{90}$ Sr UNDER CONTROLLED OXYGEN PRESSURE CONOITIONS'

$X$-AXES LABEL IS 'TIME (OAYS)'

Y-AXES LABEL IS 'FRACTIONAL RELEASE

RATE (1/DAYS)'

CURVE 1

$L A B E L=2.5 E-04$

SYMBOL = OPEN CIRCLE

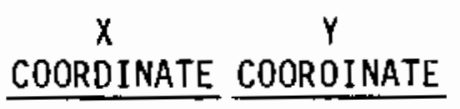

3. $5 E-05$

3. $5 \mathrm{E}-05$

6. $6 \mathrm{E}-06$

8. $3 \mathrm{E}-06$

4. $0 E-06$

3. $2 \mathrm{E}-06$

2. $5 \mathrm{E}-07$

2. $2 \mathrm{E}-07$

1. $3 \mathrm{E}-07$

1. $6 \mathrm{E}-07$

1. $4 \mathrm{E}-07$

1. $\mathrm{OE}-07$

8. $7 \mathrm{E}-08$

1. $2 \mathrm{E}-07$

1. $1 E-07$

1. 1E -07

1. $1 E-07$
CURVE 2

$\angle A B E L=6.1 \mathrm{E}-06$

$S Y M B O L=$ OPEN SQUARE
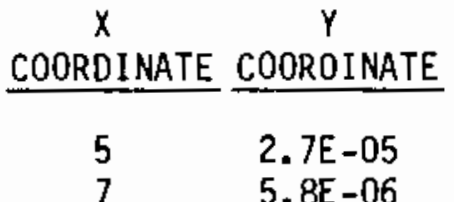

11

16

31

52

75

110

140

170

200

230

250

290

320

340

370

400

430
2. $7 \mathrm{E}-05$

5. $8 E-06$

3. $4 \mathrm{E}-06$

1. $4 E-06$

3. $1 \mathrm{E}-07$

3. $6 \mathrm{E}-07$

5. OE -07

3. $6 \mathrm{E}-07$

2. $4 \mathrm{E}-07$

2. $2 \mathrm{E}-06$

2. $4 \mathrm{E}-07$

1. $2 \mathrm{E}-07$

1. $0 \mathrm{E}-07$

4. $1 E-08$

3. $6 \mathrm{E}-08$

3. $7 \mathrm{E}-08$

3. $9 \mathrm{E}-08$

5. $0 \mathrm{E}-08$

2. $7 \mathrm{E}-08$
CURVE 3

$\angle A B E L=1.0 E-06$

SYMBOL = OPEN TR IANGLE

\begin{tabular}{c}
$X$ \\
COOROINATE \\
\hline
\end{tabular}

$\begin{array}{rr}5 & 3.1 E-05 \\ 7 & 9.0 E-06 \\ 11 & 4.5 E-06 \\ 15 & 1.2 E-06 \\ 29 & 2.1 E-07 \\ 52 & 1.2 E-07 \\ 75 & 5.5 E-08 \\ 110 & 3.2 E-08 \\ 140 & 7.1 E-08 \\ 170 & 2.3 E-07 \\ 200 & 2.5 E-08 \\ 230 & 2.8 E-08 \\ 250 & 3.1 E-08 \\ 290 & 2.2 E-08 \\ 320 & 2.0 E-08 \\ 340 & 1.5 E-08 \\ 370 & 1.2 E-08 \\ 400 & 2.1 E-08 \\ 430 & 1.4 E-08\end{array}$


REFERENCE: JOHNSON 1982, p. 25

FIGURE TITLE: 'FRACTIONAL RELEASE RATES FOR ${ }^{99}$ TC UNDER CONTROLLED OXYGEN PRESSURE CONDITIONS'

$X$-AXES LABEL IS 'TIME (DAYS)'

CURVE 1

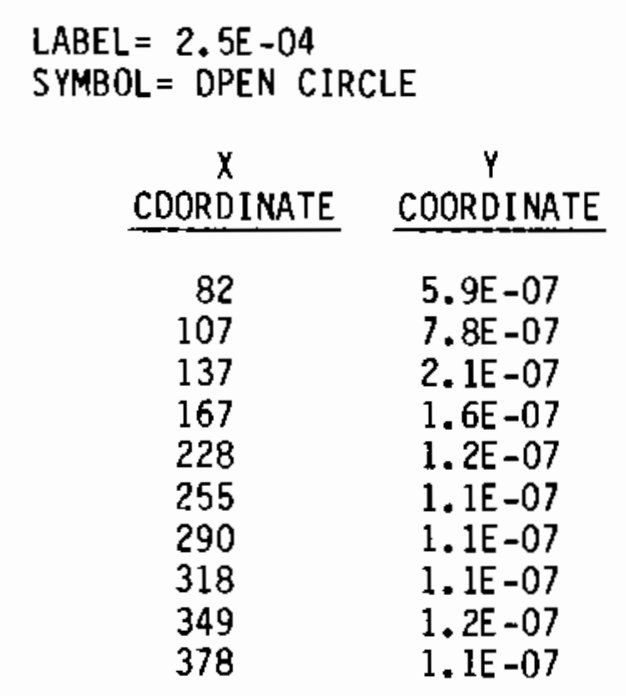

$Y$-AXES LABEL IS 'FRACTIONAL RELEASE
RATE (1/DAYS)'

CURVE 2

LABEL $=6.1 \mathrm{E}-06$
SYMBOL $=$ OPEN SQUARE

\begin{tabular}{cc}
$X$ & \multicolumn{1}{c}{} \\
COORDINATE & COORDINATE \\
\hline
\end{tabular}

194

257

289

317

349

379

410

441
1. $2 \mathrm{E}-07$

1. $0 \mathrm{E}-07$

8. $3 \mathrm{E}-08$

4. $3 \mathrm{E}-08$

4. $2 \mathrm{E}-08$

$6.4 \mathrm{E}-08$

4. $2 \mathrm{E}-08$

4. $1 \mathrm{E}-08$

8. $0 \mathrm{E} \rightarrow 08$

CURVE 3

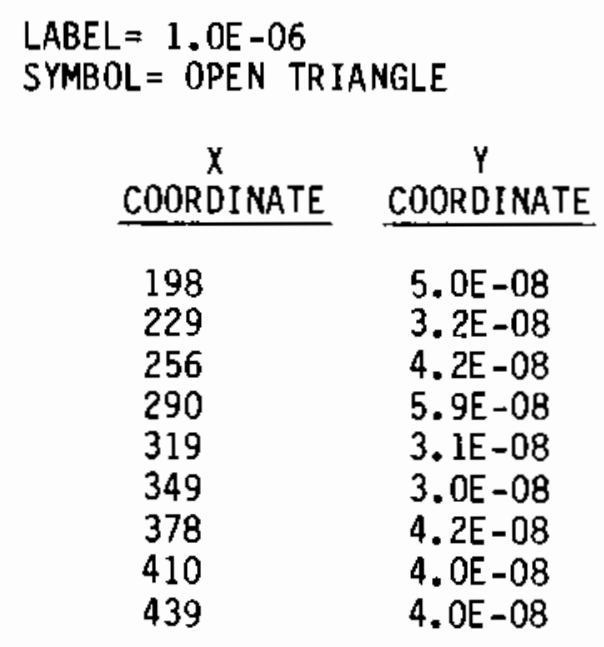

$[02] \mathrm{mo}{ }^{*}{ }^{*} \mathrm{~kg}$ e -01 
REFERENCE: JOHNSON 1982, p. 26

FIGURE TITLE: 'FRACTIONAL RELEASE RATES OF URANIUM UNDER CONTROLLED OXYGEN PRESSURE CONDITIONS'

$X$-AXES LABEL IS 'TIME (DAYS)'
$Y$-AXES LABEL IS 'FRACTIONAL RELEASE RATE (1/DAYS)'
CURVE 1

$\angle A B E L=2.5 E-04$

SYMBOL $=$ OPEN CIRCLE

\begin{tabular}{c}
$X$ \\
COORDINATE \\
\hline
\end{tabular}

$\begin{array}{rr}2 & 2.5 \mathrm{E}-06 \\ 3 & 8.0 \mathrm{E}-07 \\ 11 & 8.1 \mathrm{E}-07 \\ 15 & 2.4 \mathrm{E}-07 \\ 29 & 8.3 \mathrm{E}-08 \\ 51 & 8.3 \mathrm{E}-08 \\ 75 & 1.9 \mathrm{E}-08 \\ 109 & 1.6 \mathrm{E}-08 \\ 132 & 3.4 \mathrm{E}-08 \\ 166 & 2.7 \mathrm{E}-08 \\ 193 & 2.8 \mathrm{E}-08 \\ 228 & 2.9 \mathrm{E}-08 \\ 255 & 1.2 \mathrm{E}-08 \\ 284 & 1.1 \mathrm{E}-08 \\ 314 & 2.2 \mathrm{E}-08 \\ 348 & 2.5 \mathrm{E}-08 \\ 375 & 2.1 \mathrm{E}-08\end{array}$

CURVE 2

$\mathrm{LABEL}=6.1 \mathrm{E}-06$

SYMBOL $=$ OPEN SQUARE

\begin{tabular}{cc}
$X$ \\
COORDINATE \\
\hline
\end{tabular}

3. $9 \mathrm{E}-06$

$6.9 E-07$

5. $7 \mathrm{E}-07$

1. $0 \mathrm{E}-07$

4. $4 \mathrm{E}-08$

3. $4 \mathrm{E}-08$

7. $5 E-08$

5. $7 \mathrm{E}-08$

9. $4 \mathrm{E}-08$

3. $7 \mathrm{E}-08$

2. $5 E-08$

3. $7 \mathrm{E}-08$

3. $5 \mathrm{E}-08$

2. $6 \mathrm{E}-08$

2. $1 E-08$

1. $8 E-08$

9. $6 \mathrm{E}-09$

1. $6 \mathrm{E}-08$
CURVE 3

$\mathrm{LABEL}=1.0 \mathrm{E}-06$

SYMBOL = OPEN TR IANGLE

\begin{tabular}{cc}
$X$ & $Y$ \\
COORDINATE & COORDINATE \\
\hline
\end{tabular}

2. $0 \mathrm{E}-06$

7. $0 \mathrm{E}-07$

5. $7 \mathrm{E}-07$

6. $8 \mathrm{E}-07$

8. $2 E-08$

3. $6 \mathrm{E}-08$

2. $6 \mathrm{E}-08$

2. $4 \mathrm{E}-08$

2. $3 \mathrm{E}-08$

1. $6 \mathrm{E}-08$

2. $0 E-08$

6. $3 E-09$

9. $4 \mathrm{E}-09$

1. $6 \mathrm{E}-08$

1. $4 \mathrm{E}-08$

1. $3 \mathrm{E}-08$

1. $0 E-08$

1. $6 \mathrm{E}-09$

2. $4 \mathrm{E}-09$

8. $4 \mathrm{E}-09$ 
REFERENCE: JOHNSON et al. 1982, p. 246

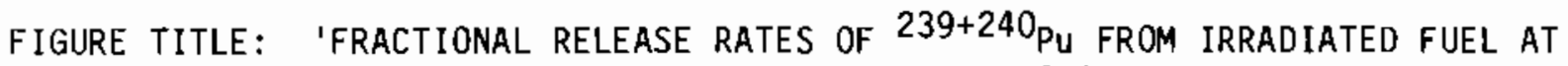
VARIOUS OXYGEN CONCENTRATIONS AT $25^{\circ} \mathrm{C}$ '

$X$-AXES LABEL IS 'TIME (DAYS)'

CURVE 1

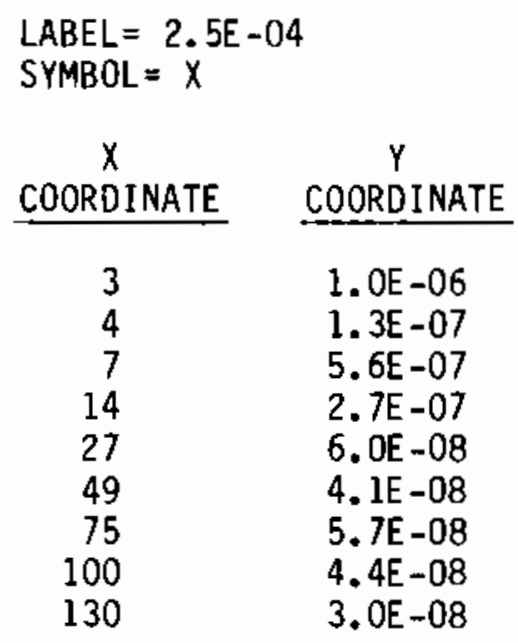

Y-AXES LABEL IS 'FRACTIONAL RELEASE
RATE (1/DAYS)'

CURVE 2

\begin{tabular}{|c|c|}
\hline \multicolumn{2}{|c|}{$\begin{array}{l}\text { LABEL }=6.1 \mathrm{E}-04 \\
\text { SYMBOL }=\text { OPEN CIRCLE }\end{array}$} \\
\hline $\begin{array}{c}x \\
\text { COORDINATE } \\
\end{array}$ & $\begin{array}{c}\text { Y } \\
\text { COORDINATE }\end{array}$ \\
\hline 3 & 5. DE - 07 \\
\hline 4 & $8.0 \mathrm{E}-08$ \\
\hline 7 & $6.3 \mathrm{E}-08$ \\
\hline 14 & $3.1 \mathrm{E}-08$ \\
\hline 27 & $1.9 \mathrm{E}-08$ \\
\hline 49 & 3. $3 \mathrm{E}-08$ \\
\hline 75 & $1.5 \mathrm{E}-08$ \\
\hline 100 & 3. $3 E-08$ \\
\hline 130 & 2.1E-09 \\
\hline
\end{tabular}

CURVE 3

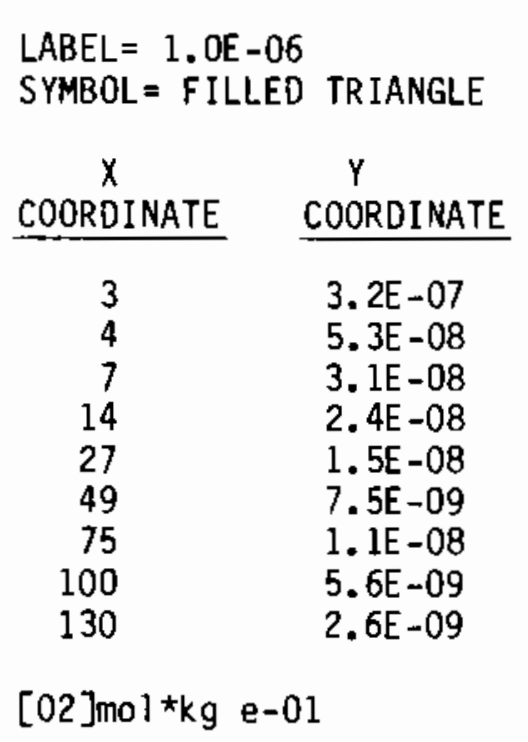


REFERENCE: JOHNSON et al. 1982, p. 247

FIGURE TITLE: 'FRACTIONAL RELEASE RATES OF ${ }^{137}$ CS FOR FUELS OF MODERATE AND HIGH POWER RATINGS'

$X$-AXES LABEL IS 'TIME (DAYS)'

CURVE 1

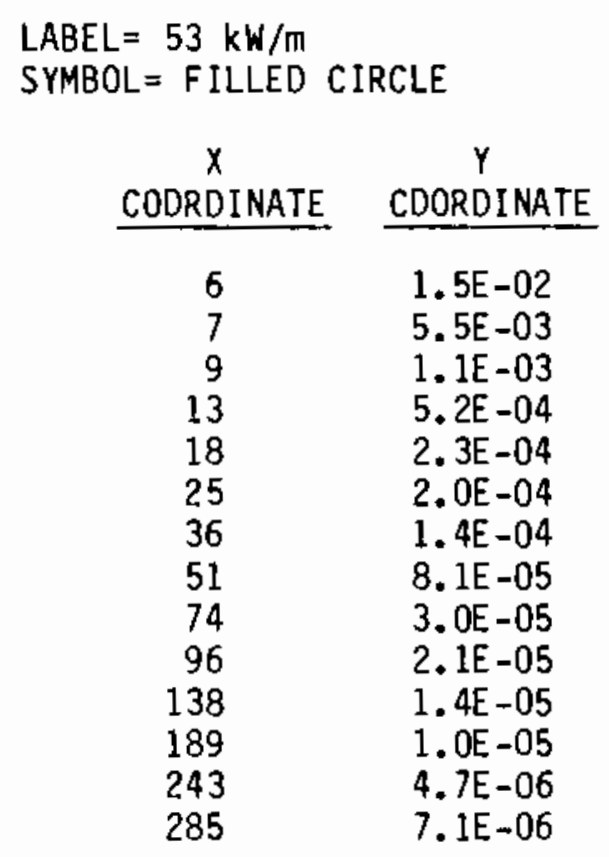

Y-AXES LABEL IS 'FRACTIONAL RELEASE RATE (1/DAYS)'

CURVE 2

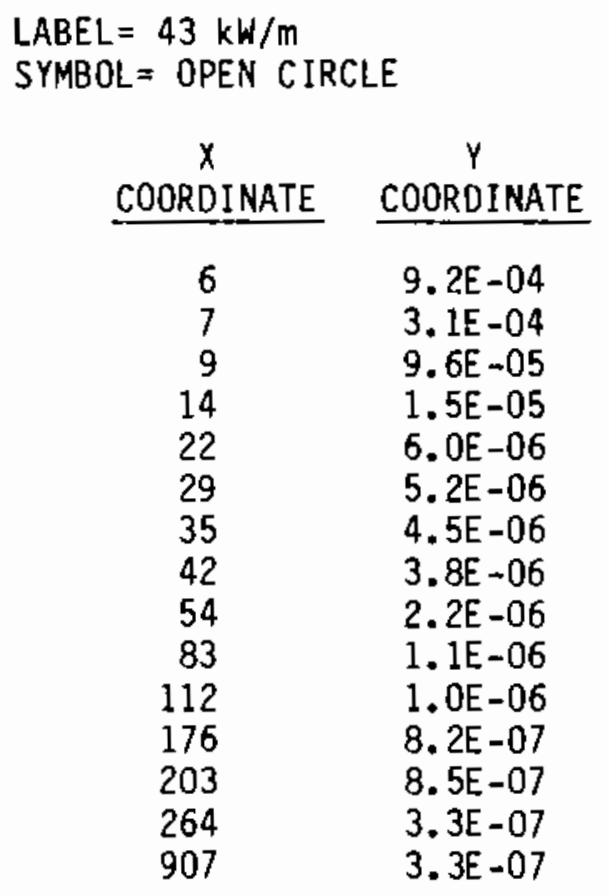


REFERENCE: JOHNSON et al. 1983, p. 473

FIGURE TITLE: 'GAS RELEASE AND CUMULATIVE ${ }^{137}$ CS LEACHING DATA FOR PICKERING BUNDLE $15527 C^{\prime}$

$X$-AXES LABEL IS 'TIME (DAYS)' CURVE 1

\begin{tabular}{|c|c|}
\hline \multicolumn{2}{|l|}{$\begin{array}{l}\text { LABEL }=\text { CURVE } 1 \\
\text { SYMBOL }=x\end{array}$} \\
\hline $\begin{array}{c}x \\
\text { COORDINATE } \\
\end{array}$ & $\begin{array}{c}Y \\
\text { COORDINATE }\end{array}$ \\
\hline 1 & 0.78 \\
\hline 3 & 1.2 \\
\hline 11 & 1.9 \\
\hline 20 & 2.2 \\
\hline 35 & 2.5 \\
\hline 60 & 2.8 \\
\hline 97 & 2.9 \\
\hline 274 & 3.1 \\
\hline
\end{tabular}

CURVE 3

LABEL $=$ CURVE 3

SYMBOL = OPEN CIRCLE

\begin{tabular}{ccc}
$\begin{array}{cc}X \\
\text { COORDINATE }\end{array}$ & & $\begin{array}{c}Y \\
\text { COORDINATE }\end{array}$ \\
\cline { 1 - 1 } 1 & & 0.80 \\
3 & & 1.2 \\
4 & & 1.5 \\
11 & & 2 \\
20 & & 2.4 \\
35 & & 2.7 \\
60 & & 2.9 \\
96 & & 3.1 \\
274 & & 3.4
\end{tabular}

Y-AXES LABEL IS 'PERCENT RELEASED'

CURVE 2

LABEL $=$ CURVE 2

SYMBOL $=X$

\begin{tabular}{ccc}
$\begin{array}{c}x \\
\text { COORDINATE }\end{array}$ & & $\begin{array}{c}y \\
\text { COORDINATE }\end{array}$ \\
\cline { 1 - 1 } 1 & & 0.63 \\
3 & & 1.0 \\
4 & & 1.2 \\
11 & 1.8 \\
21 & 2.1 \\
36 & & 2.3 \\
60 & & 2.6 \\
97 & & 2.8 \\
277 & & 3.0
\end{tabular}

CURVE 4

LABEL $=$ CURVE 4

SYMBOL = OPEN CIRCLE

\begin{tabular}{ccc}
$\begin{array}{c}x \\
\text { COORDINATE }\end{array}$ & & $\begin{array}{c}y \\
\text { COORDINATE }\end{array}$ \\
\cline { 1 - 1 } 1 & & 1.5 \\
3 & & 2.1 \\
4 & & 2.3 \\
10 & & 2.7 \\
20 & & 3.0 \\
34 & & 3.3 \\
$5 B$ & & 3.5 \\
93 & & 3.7 \\
280 & & 3.9
\end{tabular}


REFERENCE: JOHNSON et al. 1984, p. 5

FIGURE TITLE: 'PERCENTAGE ${ }^{137}$ CS AND ${ }^{129}$ I RELEASED FROM BRUCE F21271C OUTER FUEL-ELEMENT SECTIONS LEACHED IN DEIONIZED DISTILLED WATER AT $25^{\circ} \mathrm{C}$ WITH NO CARRIER PRESENT'

X-AXES LABEL IS 'TIME (DAYS)'

CURVE 1

LABEL = I WITH ATTACHED SHEATH

SYMBOL = FILLED CIRCLE

\begin{tabular}{|c|c|}
\hline $\begin{array}{c}x \\
\text { COORDINATE }\end{array}$ & $\begin{array}{c}\text { Y } \\
\text { COORDINATE }\end{array}$ \\
\hline 0 & 1. $2 E-02$ \\
\hline $\begin{array}{l}1 \\
2\end{array}$ & $\begin{array}{l}\text { 2. } 8 \mathrm{E}-02 \\
\text { 3. } 3 \mathrm{E}-02\end{array}$ \\
\hline
\end{tabular}

CURVE 3

LABEL $={ }^{137}$ Cs WITH ATTACHED SHEATH SYMBOL = FILLED CIRCLE

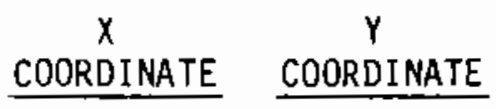

$\begin{array}{ll}0 & 0.12 \\ 1 & 0.52 \\ 1 & 1.7 \\ 2 & 1.8\end{array}$

Y-AXES LABEL IS 'INVENTORY RELEASED'

CURVE 2

LABEL = I WITH CUT OPEN SHEATH

SYMBOL = OPEN CIRCLE

\begin{tabular}{|c|c|}
\hline $\begin{array}{c}x \\
\text { COORDINATE }\end{array}$ & $\begin{array}{c}y \\
\text { COORDINATE }\end{array}$ \\
\hline 0 & 3. $1 \mathrm{E}-\mathrm{C}$ \\
\hline 1 & $\begin{array}{l}5.3 \mathrm{E}-02 \\
4.7 \mathrm{~F}-02\end{array}$ \\
\hline
\end{tabular}

CURVE 4

LABEL $={ }^{137}$ CS WITH SHEATH CUT OPEN SYMBOL $=$ OPEN CIRCLE

\begin{tabular}{ccc}
$\begin{array}{cc}x \\
\text { COORDINATE }\end{array}$ & $\begin{array}{c}Y \\
\text { COORDINATE }\end{array}$ \\
\cline { 1 - 1 } 1 & & 1.4 \\
1 & & 1.8 \\
2 & & 2.1
\end{tabular}


REFERENCE: JOHNSON et al. 1984, p. 6

FIGURE TITLE: 'PERCENTAGE ${ }^{137}$ CS AND ${ }^{129}$ I RELEASED FROM PICKERING A13894W OUTER FUEL ELEMENT SECTIONS (IN DEIONIZED DISTILLED WATER AT $25^{\circ} \mathrm{C}$ WITH $0.2 \mathrm{~g} / \mathrm{L}$ KI CARRIER)'

$X$-AXES LABEL IS 'TIME (DAYS)'

CURVE 1

\begin{tabular}{|c|c|}
\hline \multicolumn{2}{|c|}{$\begin{array}{l}\text { LABEL }={ }^{129} I \\
\text { SYMBOL }=\text { OPEN CIRCLE }\end{array}$} \\
\hline $\begin{array}{c}x \\
\text { COORDINATE }\end{array}$ & $\begin{array}{c}Y \\
\text { COORDINATE } \\
\end{array}$ \\
\hline $\begin{array}{l}0 \\
0 \\
1 \\
3 \\
4\end{array}$ & $\begin{array}{c}5.4 \mathrm{E}-02 \\
6.4 \\
9.4 \\
10 \\
11\end{array}$ \\
\hline
\end{tabular}

Y-AXES LABEL IS 'INVENTORY RELEASED ( $\%)$ ' CURVE 2

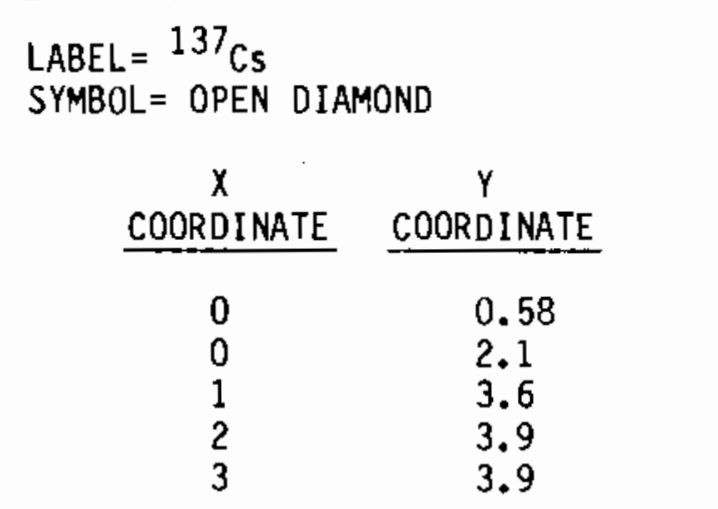


REFERENCE: WILSON AND OVERSBY 1984, p. 8

FIGURE TITLE: 'URANIUM IN SOLUTION'

X-AXES LABEL IS 'TIME (DAYS)'

CURVE 1

LABEL $=$ BARE HBR FUEL

SYMBOL $=$ OPEN CIRCLE

\begin{tabular}{ccc}
$\begin{array}{cc}X \\
\text { COORDINATE }\end{array}$ & & $\begin{array}{c}Y \\
\text { COORDINATE }\end{array}$ \\
\cline { 1 - 1 } 1 & & $4.5 \mathrm{E}+01$ \\
5 & & $0.6 \mathrm{E}-01$ \\
16 & & $0.1 \mathrm{E}-01$ \\
30 & & $0.3 \mathrm{E}-01$ \\
59 & & $0.2 \mathrm{E}-01$ \\
89 & & $0.4 \mathrm{E}-01$ \\
119 & & $0.5 \mathrm{E}-01$ \\
150 & & $0.8 \mathrm{E}-01$ \\
179 & & $0.5 \mathrm{E}-01$
\end{tabular}

CURVE 3

LABEL $=$ HOLES DEFECTS

SYMBOL = OPEN TRIANGLE

\begin{tabular}{ccc}
$\begin{array}{ccc}X \\
\text { COORDINATE }\end{array}$ & & $\begin{array}{c}Y \\
\text { COORDINATE }\end{array}$ \\
\cline { 1 - 1 } 2 & & $4.0 \mathrm{E}-03$ \\
6 & & $2.0 \mathrm{E}-03$ \\
15 & & $6.0 \mathrm{E}-03$ \\
30 & & $6.0 \mathrm{E}-03$ \\
59 & & $4.1 \mathrm{E}-03$ \\
90 & & $3.7 \mathrm{E}-03$ \\
119 & & $5.8 \mathrm{E}-03$ \\
148 & & $1.7 \mathrm{E}-02$ \\
178 & & $5.4 \mathrm{E}-03$
\end{tabular}

Y-AXES LABEL IS 'FRACTIONAL RELEASE RATE (1/DAYS)'

CURVE 2

LABEL = SPLIT DEFECTS

SYMBOL = OPEN SQUARE

\begin{tabular}{|c|c|}
\hline $\begin{array}{c}x \\
\text { COORDINATE }\end{array}$ & $\begin{array}{c}Y \\
\text { COORDINAT }\end{array}$ \\
\hline $\begin{array}{r}2 \\
6 \\
14 \\
29 \\
59 \\
90 \\
120 \\
149 \\
179\end{array}$ & $\begin{array}{l}8.2 \mathrm{E}-03 \\
3.9 \mathrm{E}-02 \\
2.7 \mathrm{E}-02 \\
2.7 \mathrm{E}-02 \\
2.3 \mathrm{E}-02 \\
2.9 \mathrm{E}-02 \\
3.9 \mathrm{E}-02 \\
2.2 \mathrm{E}-02 \\
3.3 \mathrm{E}-02\end{array}$ \\
\hline
\end{tabular}

\begin{tabular}{|c|c|}
\hline \multicolumn{2}{|c|}{ CURVE 4} \\
\hline \multicolumn{2}{|c|}{$\begin{array}{l}\text { LABEL }=\text { UNDEFECTED } \\
\text { SYMBOL = FILLED CIRCLE }\end{array}$} \\
\hline $\begin{array}{c}x \\
\text { COORDINATE }\end{array}$ & $\begin{array}{c}\text { Y } \\
\text { COOROINATE }\end{array}$ \\
\hline $\begin{array}{r}2 \\
6 \\
14 \\
30 \\
61 \\
89 \\
18 \\
49 \\
78\end{array}$ & $\begin{array}{l}2.8 \mathrm{E}-03 \\
2.0 \mathrm{E}-03 \\
1.9 \mathrm{E}-03 \\
1.8 \mathrm{E}-03 \\
3.0 \mathrm{E}-03 \\
1.7 \mathrm{E}-03 \\
1.9 \mathrm{E}-03 \\
5.7 \mathrm{E}-03 \\
2.7 \mathrm{E}-03\end{array}$ \\
\hline
\end{tabular}


REFERENCE: WILSON AND OVERSBY 1984, p. 8

FIGURE TITLE: $\quad 239+240 \mathrm{Pu}$ IN SOLUTION'

$X$-AXES LABEL IS 'TIME (DAYS)'

CURVE 1

LABEL $=$ BARE FUEL

SYMBOL = OPEN CIRCLE

\begin{tabular}{ccc}
$\begin{array}{ccc}X \\
\text { COORDINATE }\end{array}$ & & $\begin{array}{c}Y \\
\text { COOROINATE }\end{array}$ \\
\cline { 1 - 1 } 3 & & $1.4 \mathrm{E}+03$ \\
6 & & $8.0 \mathrm{E}+02$ \\
16 & & $1.2 \mathrm{E}+03$ \\
30 & & $1.4 \mathrm{E}+03$ \\
61 & & $1.0 \mathrm{E}+03$ \\
90 & & $9.7 \mathrm{E}+02$ \\
119 & & $9.4 \mathrm{E}+02$ \\
150 & & $7.4 \mathrm{E}+02$ \\
179 & & $9.0 \mathrm{E}+02$
\end{tabular}

CURVE 3

$\angle A B E L=$ HOLE OEFECTS

SYMBOL = OPEN TRIANGLE

\begin{tabular}{|c|c|}
\hline $\begin{array}{c}x \\
\text { COORDINATE }\end{array}$ & $\begin{array}{c}Y \\
\text { COORDI NATE }\end{array}$ \\
\hline $\begin{array}{r}1 \\
6 \\
15 \\
31 \\
59 \\
90 \\
120 \\
150 \\
177\end{array}$ & $\begin{array}{l}1.4 \mathrm{E}+00 \\
1.4 \mathrm{E}+00 \\
6.2 \mathrm{E}+00 \\
1.3 \mathrm{E}+01 \\
1.5 \mathrm{E}+01 \\
1.8 \mathrm{E}+01 \\
1.9 \mathrm{E}+01 \\
1.9 \mathrm{E}+01 \\
1.9 \mathrm{E}+01\end{array}$ \\
\hline
\end{tabular}
$Y$-AXES LABEL IS 'FRACTIONAL RELEASE RATE (1/OAYS)'

CURVE 2
LABEL = SPLIT DEFECTS

SYMBOL = OPEN SQUARE

\begin{tabular}{ccc}
$\begin{array}{cc}X \\
\text { COOROINATE }\end{array}$ & & $\begin{array}{c}Y \\
\text { COORDINATE }\end{array}$ \\
\cline { 1 - 1 } 2 & & $2.8 \mathrm{E}+00$ \\
7 & & $5.5 \mathrm{E}+00$ \\
15 & & $7.5 \mathrm{E}+00$ \\
29 & & $2.6 \mathrm{E}+01$ \\
60 & & $3.8 \mathrm{E}+01$ \\
89 & & $5.9 \mathrm{E}+01$ \\
118 & & $1.0 \mathrm{E}+02$ \\
149 & & $5.9 \mathrm{E}+01$ \\
178 & & $7.7 \mathrm{E}+01$ \\
813 & & $7.7 \mathrm{E}+01$
\end{tabular}

CURVE 4

\section{LABEL $=$ UNDEFECTED \\ SYMBOL = FILLED CIRCLE}

\begin{tabular}{ccc}
$\begin{array}{cc}X \\
\text { COORDINATE }\end{array}$ & & $Y$ \\
\cline { 1 - 1 } 2 & & $Y$ \\
& & $0.8 \mathrm{E}+00$ \\
5 & & $0.8 \mathrm{E}+00$ \\
15 & & $1.1 \mathrm{E}+00$ \\
29 & & $4.2 \mathrm{E}+00$ \\
61 & & $6.5 \mathrm{E}+00$ \\
90 & & $8.6 \mathrm{E}+00$ \\
120 & & $1.0 \mathrm{E}+01$ \\
148 & & $1.0 \mathrm{E}+01$ \\
178 & & $1.1 \mathrm{E}+01$
\end{tabular}


REFERENCE: WILSON AND OVERSBY 1984, p. 8

FIGURE TITLE: $" 137$ CS IN SOLUTION"

$X$-AXES LABEL IS 'TIME (DAYS)'

CURVE 1

LABEL = BARE FUEL

SYMBOL = OPEN CIRCLE

\begin{tabular}{ccc}
$\begin{array}{cc}X \\
\text { COORDINATE }\end{array}$ & & $\begin{array}{c}Y \\
\text { COORDINATE }\end{array}$ \\
\cline { 1 - 1 } 1 & & $9.9 E+06$ \\
4 & & $1.6 E+07$ \\
13 & & $2.0 E+07$ \\
29 & & $2.1 E+07$ \\
60 & & $1.9 E+07$ \\
89 & & $1.2 E+07$ \\
119 & & $5.0 E+06$ \\
149 & & $2.5 E+06$ \\
178 & & $1.4 E+06$
\end{tabular}

CURVE 3

LABEL $=$ HOLE DEFECTS

SYMBOL = OPEN TRIANGLE

\begin{tabular}{ccc}
$\begin{array}{cc}X \\
\text { COORDINATE }\end{array}$ & & $\begin{array}{c}Y \\
\text { COORDINATE }\end{array}$ \\
\cline { 1 - 1 } 1 & & $1.3 E+04$ \\
5 & & $2.4 E+04$ \\
14 & & $1.1 E+06$ \\
29 & & $2.7 E+06$ \\
59 & & $4.2 E+06$ \\
89 & & $5.0 E+06$ \\
120 & & $4.2 E+06$ \\
149 & & $4.9 E+06$ \\
178 & & $4.9 E+06$
\end{tabular}

$Y$-AXES LABEL IS 'FRACTIONAL RELEASE RATE (1/DAYS)'

CURVE 2

$\angle A B E L=S L I T$ DEFECTS

SYMBOL = OPEN SQUARE

\begin{tabular}{ccc}
$\begin{array}{ccc}X \\
\text { COORDINATE }\end{array}$ & & $\begin{array}{c}Y \\
\text { CODRDINATE }\end{array}$ \\
\cline { 1 - 1 } 1 & & $2.4 \mathrm{E}+04$ \\
5 & & $4.9 \mathrm{E}+05$ \\
13 & & $1.5 \mathrm{E}+06$ \\
29 & & $3.4 \mathrm{E}+06$ \\
59 & & $5.9 \mathrm{E}+06$ \\
90 & & $8.7 \mathrm{E}+06$ \\
119 & & $9.4 \mathrm{E}+06$ \\
149 & & $1.0 \mathrm{E}+07$ \\
179 & & $1.0 \mathrm{E}+07$
\end{tabular}

CURVE 4

LABEL = UNOEFECTED

SYMBOL = FILLED CIRCLE

\begin{tabular}{cc}
$X$ & $Y$ \\
COORDINATE & CDORDINATE \\
\hline
\end{tabular}

$\begin{array}{rr}1 & 2.9 \mathrm{E}+03 \\ 5 & 2.9 \mathrm{E}+03 \\ 14 & 3.5 \mathrm{E}+03 \\ 30 & 2.9 \mathrm{E}+03 \\ 59 & 3.2 \mathrm{E}+03 \\ 90 & 3.5 \mathrm{E}+03 \\ 119 & 3.5 \mathrm{E}+03 \\ 149 & 3.5 \mathrm{E}+03 \\ 180 & 3.8 \mathrm{E}+03\end{array}$


REFERENCE: WILSON AND OVERSBY $1985, p .3$

FIGURE TITLE: 'URANIUM IN UNFILTERED SOLUTION'

$X$-AXES LABEL IS 'TIME (DAYS)'

CURVE 1

$\angle A B E L=B A R E \quad H B R$ FUEL SYMBOL = FILLED CIRCLE

\begin{tabular}{ccc}
$\begin{array}{c}X \\
\text { COORDINATE }\end{array}$ & \multicolumn{1}{c}{$\begin{array}{c}Y \\
\text { COORDINATE }\end{array}$} \\
\cline { 1 - 2 } 3 & & 4.1 \\
7 & & 4.4 \\
10 & 4.6 \\
21 & 3.8 \\
30 & 3.6 \\
63 & 2.3 \\
120 & 1.5 \\
181 & 1.3 \\
223.0742 & & 1.144536
\end{tabular}

CURVE 3

LABEL $=$ HOLE DEFECTS

SYMBOL = OPEN TRIANGLE

\begin{tabular}{ccc}
$\begin{array}{c}X \\
\text { COORDINATE }\end{array}$ & & $\begin{array}{c}Y \\
\text { COORDINATE }\end{array}$ \\
\cline { 1 - 1 } 3 & & $7.1 \mathrm{E}-03$ \\
7 & & $8.9 \mathrm{E}-03$ \\
21 & & $1.0 \mathrm{E}-02$ \\
31 & & $6.7 \mathrm{E}-03$ \\
64 & & $6.7 \mathrm{E}-03$ \\
121 & & $4.6 \mathrm{E}-03$ \\
182 & & $4.6 \mathrm{E}-03$ \\
223 & & $5.5 \mathrm{E}-03$
\end{tabular}

Y-AXES LABEL IS 'FRACTIONAL RELEASE RATE (1/DAYS)"

CURVE 2

$\angle A B E L=S L I T$ DEFECT

SYMBOL = DPEN SQUARE

\begin{tabular}{ccc}
$\begin{array}{c}x \\
\text { COORDINATE }\end{array}$ & $\begin{array}{c}y \\
\text { COORDINATE }\end{array}$ \\
\cline { 1 - 1 } 3 & & $2.8 \mathrm{E}-02$ \\
7 & & $5.0 \mathrm{E}-02$ \\
21 & & $5.3 \mathrm{E}-02$ \\
30 & & $6.1 \mathrm{E}-02$ \\
63 & & $6.8 \mathrm{E}-02$ \\
120 & & $6.5 \mathrm{E}-02$ \\
182 & & $8.7 \mathrm{E}-\mathrm{D} 2$ \\
223 & & $9.5 \mathrm{E}-02$
\end{tabular}

CURVE 4

\section{$\angle A B E L=$ UNDEFECTED \\ SYMBOL $=$ OPEN CIRCLE}

\begin{tabular}{ccc}
$\begin{array}{c}x \\
\text { COORDINATE }\end{array}$ & & $\begin{array}{c}y \\
\text { COORDINATE }\end{array}$ \\
\cline { 1 - 1 } 3 & & $1.5 \mathrm{E}-02$ \\
7 & & $2.0 \mathrm{E}-02$ \\
21 & & $2.2 \mathrm{E}-02$ \\
30 & & $1.9 \mathrm{E}-02$ \\
64 & & $1.6 \mathrm{E}-02$ \\
121 & & $1.4 \mathrm{E}-02$ \\
182 & & $1.4 \mathrm{E}-02$ \\
223 & & $1.1 \mathrm{E}-02$
\end{tabular}



APPENDIX B

ANNOTATED BIBLIOGRAPHY OF LITERATURE ON SPENT FUEL/UO2 CHARACTER IZATION 
APPENDIX B

ANNOTATED BIBLIOGRAPHY OF LITERATURE ON SPENT FUEL/UO, CHARACTERIZATION

Due to the heterogeneous nature of spent nuclear fuel, it is critical to have accurate, detailed information on the characteristics of the materials being used to evaluate the performance of spent fuel as a potential waste form. This appendix presents the Titerature compiled for the informal Waste Package Program (WPP) library at PNL on characterization and the properties of spent fuel and $\mathrm{UO}_{2}$. The annotations are either the abstract or a synopsis of the publication. Exhaustive reviews of the literature in this area were not conducted; the intent of this appendix is to present the available literature.

This appendix is organized with groupings of the various publications into subject areas. The sections address subject areas of general information on spent fuel characterization (including general reference material), experimental methods of characterization, data on destructive and nondestructive testing of spent fuel, and modeling efforts related to spent fuel characterization. Literature references are also included for fuel restructuring, radionuclide redistribution within the spent fuel, and out-of-reactor fuel performance. These last three subject areas are given without individual summaries of the articles.

GENERAL INFORMATION ON SPENT FUEL CHARACTERIZATION

Almassy, M. Y. and R. E. Woodley, August 1972. Possible Effects of U0 $20 x i d a-$ tion on Light Water Reactor Spent Fuel Performance in Long-Term Geotogic Disposa 1. HEDL-TC-1502, Rev. 1. Hanford Engineering Development Laboratory, Richland, WA.

A technical assessment of published literature representing the current level (August 1982) of understanding of spent fuel characteristics and conditions that may degrade pellet integrity during a geologic disposal sequence. The main emphasis is the identification of the main modes of $\mathrm{UO}_{2}$ degradation in a geologic setting (69 references). 
Barner, J. 0. 1984. LWR Spent Fuel Approved Testing Materials for Radionuclide Release Studies. PNL-4686, UC-70, Pacific Northwest Laboratory. Richland, WA.

Criteria are defined for the selection of light water reactor (LWR) spent fuels for use as MCC-Approved Testing Materials (ATMs) in radionuclide dissolution and interaction studies. Fuel-related characteristics affecting the release of radionuclides from spent fuel are reviewed and their pertinence evaluated. ATM spent fuel criteria are defined and classes of ATM spent fuels are determined. The available inventory of governmentowned LWR spent fuel is identified and current plans for acquisition by the MCC are summarized. The characterization data to be supplied with the spent fuel ATMs are also described (11 references).

Belle, J., ed. 1961. Uranium Dioxide: Properties and Nuclear Applications. Naval Reactors, Division of Reactor Development, Unites States Atomic Energy Commission, U.S. Government Printing Office, Washington D.C.

A textbook presentation of $\mathrm{UO}_{2}$ with regard to the physical properties of $\mathrm{UO}_{2}$ and the detailed phase reTationships in the uranium-oxygen system, sofid state reaction and the oxidation and corrosion behavior of uranium dioxide, and the irradiation behavior and performance as a fuel. Numerous references to the literature prior to 1961.

Funk, C. W. and L. D. Jacobson, May 1978. Inventory and Characterization of Spent LWR Fuel. HEDL-TME 77-82, Hanford Engineering Development Laboratory. Richland, WA.

An inventory of spent LWR fuel discharged from reactors and stored in water basins up to 1976. Defective fuel is identified and categorized, and the trends of failed fuel are evaluated for their impact on the operation of receiving facilities. Possible failure mechanisms that lead to the release of radioactivity have been identified. The sources and levels of activity are estimated for typical LWR spent fuel assemblies (38 references).

Greene, E. M. 1980. Spent Fuel Data for Waste Storage Programs. HEDL-TME 79-20, Hanford Engineering Development Laboratory, Richland, WA.

A compilation of data on LWR spent fuel for dissemination to participants in DOE-sponsored waste storage programs. Included are mechanical descriptions of the existing major types of LWR fuel assemblies, fission product. inventories for spent LWR fuel calculated by the ORIGEN code, decay heat data, and inventories of LWR spent fuel currently in storage, with projec:tions of future quantities (25 references).

Houston, M. D. 1978. "Properties of Spent Fuel." In Proceedings of the Conference on High-Level Radioactive Solid Waste Forms, NUREG/CP-0005, Denver. Co, Nuclear Regulatory Commission, Washington, OC., p. 561-589. 
The properties of spent fuel from current commercial nuclear power reactors are discussed in this review of the literature by the NRC. The major topics are as follows: fission product formation, fission product relocation and release, pellet cracking and relocation, fuel-to-cladding interaction, and Zircaloy growth and embrittlement. The chemical and physical properties of reactor fuel after achieving its designed irradiation exposure are described. The integrity of spent fuel rods is discussed as it relates to short- and long-term storage (39 references and panel discussion).

Johnson, L. H. and J. L. Crosthwaite, November 1984. Fuel Characterization Research for the Canadian Nuclear Fuel Waste Management Program. AECL-8375. Whiteshell Nuclear Research Estabi ishment, Atomic Energy of Canada Limited. Pinawa, Manitoba, Canada.

An outline of the fuel characterization work being performed in support of the Canadian Nuclear Fuel Waste Management Program. A general evaluation of CANDU fuel characteristics is given with regard to its use as a waste form (29 references).

01 ander, D. R., 1976. Fundamental Aspects of Nuclear Reactor Fuel Elements, TID-26711-P1, Technical Information Center, Energy Research and Development Administration.

Covers the general knowledge needed to understand the subsequent discussions of the properties and behaviors of oxide nuclear fuel. The book includes references to advanced fuels as well as a companion volume Solution to Problems which contains solutions to many of the problem sets contained in the text (numerous literature references).

Rothman, A. J. 1984. Potential Corrosion and Degradation Mechanisms of Zircaloy Cladding on Spent Nuclear Fuel in a Tuff Repository. UCID-20172, Lawrence Livermore National Laboratory, Livermore, CA.

A literature review of the potential corrosion and degradation processes applicable to Zircaloy cladding on spent nuclear fuel in a tuff repository. The author concludes that failure due to oxidation of the Zircaloy is not credible, mechanical overload is not a problem, and hydride cracking is not anticipated for the bulk of spent fuel pins. Also, it is concluded that insufficient information exists to evaiuate stress corrosion cracking, and some experimental confirmation of crack depths and the effect of slow cooling on the formation of radial hydrides is needed ( 89 references).

Sutherland, S. H. and D. E. Bennett, September 1979. Defense High-Level Waste and Spent Fuel Characterization for Geologic Waste Repositories. SAND79-0172, Sandia Laboratories, Albuquerque, NM. 
Results are given for the SANDIA-ORIGEN calculated thermal output and radionuclide content for one spent fuel type from a pressurized water reactor and five spent fuel types from a boiling water reactor

(7 references).

Technical Reports Series No. 39, Thermodynamic and Transport Properties of Uranium Dioxide and Related Phases. Report of the Panel on Thermodynamic and Transport Properties of Uranium Dioxide and Related Phases held in Vienna March 16-20, 1964.

A summary report detailing the knowledge as of 1964 of the structure of $\mathrm{UO}_{2}$, thermodynamics, surface and oxidation properties, physical properties, practical implications of the thermodynamic and transport properties, and conclusions (184 references and 12 reports reviewed).

Woodley, R. E., October 1983. The Characteristics of Spent LWR Fuel Relevant to Its Storage in Geologic Repositories. HEDL-TME 83-28, Hanford Engineering Development Laboratory, Richland, WA.

A summary of data on spent LWR fuel (Turkey Point). Fuel rod cladding integrity and conditions within fuel rods established during reactor residence as they affect storage in geologic repositories are emphasized.

\section{EXPERIMENTAL METHDDS OF CHARACTERIZATION}

Davis, R. B. (HEDL), V. Pasupathi, D. E. Stelirecht (BCL), R. L. Fish (HEDL). 1980. "Remote Characterization of Spent LWR Fuel for Geologic Disposal Demonstrations," Spent-Fuel Handling and Storage. Trans, of Am. Nuc. Soc., Vo1. 34, p. $838-839$.

A discussion of the remote handling and examination of spent fuel conduc ted to determine the effect of geologic disposal demonstration tests on the ability of spent fuel to contain radionuclides (1 reference).

De Raedt, Ch., J. L. Genicot, L. Leenders, Dctober 1-5, 1979, Dosimetry Methods for Fuels, Cladding and Structural Materials. Proceedings of the Third ASTM-

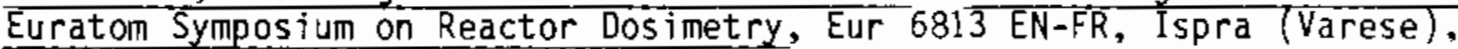
Italy.

Brief discussions of the experimental techniques for nondestructive testing of nuclear fuel assemblies. The aim of the examinations is to obtain information on burnup, power distribution, fast neutron fluence, and gadolinium burnup. The techniques discussed are gamma spectroscopy in hot cells and underwater in storage pools, and neutron radiography (3 references). 
Fish, R. L., R. B. Davis, V. Pasupathi (BCL), and R. W. Klingensmith (BCL). March 1980. Spent Fuel Characterization for the Commercial waste and Spent Fuel Packaging Program. HEDL-TC-1384, Hanford Engineering Development Laboratory, Richland, WA.

A discussion of the rationale for spent fuel characterization and 20 detailed procedures for examination of spent nuclear fuel ( 5 references).

Jenson, E. D., September 1982. Analytical Techniques for Characterization of Spent LWR Fuels with Respect to Properties Pertinent to Leaching and Dissolution. HEDL-7206, Hanford Engineering Development Laboratory, Richland, WA.

The report identifies the following as key characterization needs with respect to understanding leaching and dissolution behavior from spent LWR fuel: 1) the surface area exposed to water, 2) grain boundary conditions, 3) nature of fission product phases, 4) residence position of fission products, and 5) surface oxidation state.

The techniques to evaluate these five characteristics are discussed. The necessary precision of the measurements and limitations of the equipment are compared (11 references).

Post-irradiation Examination. Proceedings of the Conference held May 13-16, 1980 in Grange-over-Sands. British Nuclear Energy Society, London, England.

This volume contains several articles in the following subject areas:

- achievements and aims of post-irradiation examination

- new and improved nondestructive techniques

- data handling

- destructive techniques

- recent operational and management experience with established postirradiation examination facilities

- recently built, commissioned or refurbished facilities

- future trends.

It also contains brief papers on nondestructive techniques and destructive techniques. The papers cover the European and U.S. programs in these areas to the date of the conference.

Untermyer, S., II, January 1983. Development and Test of Methods for the Nondestructive Assay of Spent-Fuel Assemblies. NP-2812, Research Project 1578-1. Prepared by National Nuclear Corporation, Mountain View, CA.

Several methods were tested for the nondestructive assay of irradiated nuclear fuel assemblies stored in water-filled pools: 1) burnup measurement by neutron emission, 2) residual fissile measurement by multiplication change with boron displacement, and 3) residual fissile measurement by neutron-source multiplication. It was found that both burnup and 
residual fissile content could be measured through counting neutron emission from the fuel, both with and without a neutron source.

SPECIFIC DATA FROM TURKEY POINT AND H. B. ROBINSON FUEL CHARACTERIZATION

Atkin, S. D. 1981. Destructive Examination of 3-Cycle LWR Fuel Rods from Turkey Point Unit 3 for the CTimax - Spent Fuel Test. HEDL-TME 80-89, Hanford Engineering Development Laboratory, Richland, WA.

The destructive examination of five LWR rods from the Turkey Point Unit 3 reactor are presented. The examinations included fission gas collection and analyses, burnup and hydrogen analyses, and a metallographic evaluation of the fuel, cladding, oxide, and hydrides. The rods exhibited a low fission gas release with all other results appearing representative for pressurized water reactor fuel rods with similar burnups (28 GWd/MTU) and operating histories (11 references).

Barner, J. 0. 1984. Characterization of LWR Spent Fuel MCC-Approved Testing Material - ATM-101. PNL-5109, Pacific Northwest Laboratory, Richland, WA.

Characterization of the MCC testing material ATM-101 (i.e. H. B. Robinson spent fuel rods) is provided in the following areas:

- reactor, assembly, and rod descriptions

- assembly BO-5 irradiation history

- a description of unusual incidents that occurred to the rods

- fission gas release measurements

- results of ceramography/metallography examinations

- fuel burnup measurement results and correlations

- results of gamma scanning

- calculated values of the radionuclide inventory

- results of radionuclide chemical analyses.

Results from other studies and the distribution of ATM-101 is included. Intended to be a "living" document; will be updated as new information becomes available (6 references).

Davis, R. B. and V. Pasupathi. 1981. Data Summary Report for the Destructive Examination of Rods $67,69,38,19$, and H6 from Turkey Point Fuel Assembly B17. HEDL-TME 80-85, Hanford Engineering Development Laboratory, Rich1and, WA.

Destructive examination results of five spent fuel rods from a Turkey Point Unit 3 pressurized water reactor. Examinations included fission gas analysis, cladding hydrogen content analysis, fuel burnup analysis, metallographic examinations, autoradiography and shielded electron microprobe analysis. All rods were found to be of sound integrity with an average burnup of 27 GWd/MTU and a $0.3 \%$ fission gas release ( 3 references). 
Davis, R. B. 1981. Pre-Test Nondestructive Examination Data Summary Report on Turkey Point Spent Fuel Assemblies D01, D04 and D06 for the Climax--Spent Fuel Test. HEDL-TME 80-83, Hanford Engineering Development Laboratory, Richland, WA.

Fuel assembly sip testing concluded no leaking rods were among the thirteen fuel assemblies (Turkey Point fuel) included in the Climax--Spent Fuel Test. Detailed nondestructive examination of three (D01, D04, and D06) of the thirteen assemblies is presented (5 references).

Davis, R. B. 1980. Data Report for the Nondestructive Examination of Turkey Point Spent Fuel As sembilies B02, B03, B17, B41 and 843. HEDL-TME 79-68, Hanford Engineering Development Laboratory, Richland, WA.

Fuel assembly sip testing concluded that assembly Bl7 (Turkey Point fuel) had no leaking rods. Detailed nondestructive examination of $f i v e$ (B02, $\mathrm{B} 03, \mathrm{~B} 17, \mathrm{~B} 41$ and $\mathrm{B} 43$ ) of the thirteen assemblies mentioned in the previous article is presented (no references).

Wilson, C. N. 1985. Microstructural Characteristics of PWR Spent Fuel Relative to its Leaching Behavior. HEDL-SA-3313, Presented at The American Ceramic Society 87th Annual Meeting, Cincinnati, $\mathrm{OH}$.

Microstructural, compositional and thermochemical properties of $H$. B. Robinson spent fuel are discussed relative to its potential performance as a high-level nuclear waste form under proposed tuff repository conditions. Pre- and post-test microstructural characterization data and selected summary radionuclide release data are presented (7 references).

\section{MODELING ACTIVITIES PERTINENT TO SPENT FUEL CHARACTERIZATION}

Edlund, 0ve. 1983. Calculation of Activity Content and Related Properties in PWR and BWR Fuel using ORIGEN 2. Situdsvik Arbetsrapport--Technical Report, 83-03-07, Nw-82/191, Nykoping, Sweden.

This report lists the conditions for calculations of the core inventory for a PWR and BWR. The calculations have been performed using the computer code ORIGEN 2. The amount (grams), the total radioactivity (bequerels), the thermal power (watts), the radioactivity from alpha decay (bequerels), and the neutron emission (neutrons/sec) from the core after the last burnup are determined.

A11 parameters are calculated as a function of burnup and the natural decay, the latter over a period of $0-1.0 E 07$ years. The calculations are performed for 68 heavy nuclides, 60 daughter nuclides, to the heavy nuclides with atomic numbers under 92, 852 fission products, and 7 light nuclides (18 references). 
Fields, S. R. 1982. SAM, a Computer Model to Determine the Effective Surface Area of a Spent Fuel Pellet Immersed in Water. HEDL-7208, Hanford Engineering Development Laboratory, Richland, WA.

A mathematical simulation model, SAM (Surface Area Model), was developed to determine the effective surface area of a cracked, porous spent fuel pellet immersed in water. The primary immediate application of SAM is to determine the "time zero" or initial effective surface area of spent fuel. in underground storage, available for contact with ground water after a hypothetical breach of the waste package ( 3 references).

Notley, M. J. F. 1979. "ELESIM: A Computer Code for Predicting the Performance of Nuclear Fuel Elements." Nuclear Technology 44:455.

The ELESIM code models a single fuel element in a one-dimensional axisymmetric manner. The constituent subroutines are physically based (rather than empirical) models, and include such phenomena as fuel-to-sheath heat transfer; temperature and porosity dependence of fuel thermal conductivity; burnup-dependent neutron flux depression; burnup- and microstructuredependent fission product gas release; fuel thermal expansion, swelling and densification; and stress-, dose-, and temperature-dependent agreement with experimental data (25 references).

FUEL RESTRUCTURING AND RADIONUCLIDE REDISTRIBUTION

The informal WPP library at PNL contains the following articles which present several aspects of fuel restructuring and radionuclide redistribution within spent fuel. These articles are of particular importance in developing models, such as those described in the last section, of the restructuring and redistribution in terms of easily measured characteristics of the fuel (i.e. burnup, linear power, peak temperatures.) Without the ability to model these phenomena, the scope of the characterization would have to be greatly increased to properly account for the many different fuel types and fuel histories.

Adamson, M. G. and S. Vajdyanathan (G.E. Sunnyvale). 1981. "Mechanistic Models for Cesium Thermomigration and Cesium-Fuel Chemomechanical Interactions in Mixed-0xide Fuel Pins." Transactions of the American Nuclear Society. $38: 289-291$.

Baker, C. 1976. "The Fission Gas Bubble Distribution in Uranium Dioxide from High Temperature Irradiated SGHWR Fuel Pins." Journal of Nuclear Materia\}s. $66: 283-291$. 
Besmann, T. E., and T. B. Lindemer. 1977. "Chemical Thermodynamics of the System Cs-U-Zr-H-I-0 in the Light Water Reactor Fuel-Cladding Gap." Nuclear Technology. 40:297.

Branman, J. I., R. M. Sharpe, D. Thom and G. Yates. 1968. "Metallic FissionProduct Inclusions in Irradiated 0xide Fuels." Journal of Nuclear Materials. 25:201-215.

Bramman, J. I., and H. J. Powe11. 1975. "Redistribution of Fuel Fission Products in Irradiated 0xide Fuel Pins." J. Br. Nucl. Energy Soc. 1:63-75.

Bray, L. A., L. G. Morgan and L. L. Burger. 1981. "Therma T Outgassing of Irradiated Fuel." Transactions of the American Nuclear Society. 39:219-220.

Bray, L. A., L. L. Burger, L. G. Morgan, and D. L. Baldwin. 1983. Thermal Release of Volatile Fission Products from Irradiated Nuclear Fuel. PNL-4488, Pacific Northwest Laboratory, Richland, WA.

Cubicciotti, D, and J. E. Sanecki. 1978. "Characterization of Deposits on Inside Surfaces of LWR Cladding." Journal of Nuclear Materials. 78:96-111

Davies, J. H., and F. T. Ewart. 1971. "The Chemical Effects of Composition Changes in Irradiated 0xide Fuel Materials." Journal of Nuclear Materials. $41: 143-155$.

Davies, J. H., F. T. Frydenbo, and M. G. Adamson. 1979. "Determination of the Chemical Activity of Fission Product Iodine in Zircaloy Clad U0, Fuel

Rods." Journal of Nuclear Materials. 80:366-370.

Ewart, F. T., R. G. Taylor, J. M. Horspool, and G. James, 1976. "The Chemical Effects of Composition Changes in Irradiated 0xide Fuel Materials II-Fission Product Segregation and Chemical Equilibria." Journal of Nuclear Materials. $61: 254-270$.

Findlay, J. R. 1973. "The Birth, Abundance and Movement of Fission Products Through Fuel." Journal of the British Nuclear Society. 12:415-419.

Forsberg, K. and A. R. Massih. 1985. "Fission Gas Release Under Time-Varying Conditions." Journal of Nuclear Materials. 127:141-145.

Friskney, C. A. and J. A. Turnbul1. 1979. "The Characteristics of Fission Gas Release from Uranium Dioxide During Irradiation." Journal of Nuclear Materials. 79:184-198.

Guardini, S. and G. Guzzi, 1981. "Post Irradiation Analysis of BWR and PWR Fuel Samples: Experimental Results and Their Interpretation." "Nuclear Materials Management." In Proceedings of the Institute of Nuclear Materials Management Conference, San Francisco, CA. pp. 90-94. 
Hastings, I J., D. H. Rose and J. Baird. 1976. "Identification of Precipitates Associated with Intergranular Fission Gas Bubbles in Irradiated $\mathrm{UO}_{2}$ Fuel." Journal of Nuclear Materials. 61:229-331.

Hastings, I. J., et al. 1978. "Irradiation-Induced Volume Changes in Commercial $\mathrm{UO}_{2}$ Fuel: Comparison with Model Prediction." Journal of Nuclear Materials. $75: 301-303$.

Hermann, A. and R. Berndt. 1983. "New Possibilities in Isotope Correlation Analysis of Spent Nuclear Fuel." J. Radioanal. Chem. 80(1-2):189-198.

Jeffery, B. M. 1966. "Microanalysis of Inclusions in Irradiated $\mathrm{UD}_{2}$ " Journal of Nuclear Materials. 22:33-40.

Johnson, L. H. S. Stroes-Gascoyne, J. D. Chen, M. E. Attas, D. M. Sellinger and H. G. Delaney. 1984. "The Relationship Between Fuel Element Power and the Leaching of ${ }^{\mathrm{S}} 137$ and I 129 from Irradiated $\mathrm{UO}_{2}$ Fuel." Proceedings of the Topical Meeting on Fission Product Behavior and Source Term Research. Snowbird, UT, JuTy 15-19, 1984, p. 15-1 to 15-12.

Kleykamp, H. 1979. "The Chemical State of LWR High-Power Rods Under Irradiation." Journal of Nuclear Materials. 84:109-117.

Koizumi, M., M. Satoh, and K. Noro. 1974. "Phase Study on Solid Fission Prod-ucts, $\mathrm{Ba} \mathrm{Sr}$ and $\mathrm{Zr}$ in 0xide Fuel." Journal of Nuclear Materials. 51:90-94.

Lewis, W. B., J. R. MacEwan, W. H. Stevens, and R. G. Hart. 1964. Fission-Gas Behavior in $\mathrm{UO}_{2}$ Fuel. AECL-2019, Chalk River Nuclear Laboratories, Chalk River, Ontario, Canada.

Lorenz, R. A., J. L. Collins, A. P. Malinauskas, 0. L. Kirkland, and R. L. Towns. 1980. Fission Product Release From Highly Irradiated LWR Fuel. NUREG/CR-0722 ORNL/NUREG/TM-287/R1, Oak Ridge National Laboratory, Oak Ridge, TN.

Manzel, R., F. Sontheimer and R. Wurtz. 1984. "The Radial Distribution of Fission Gases and Other Fission Products in Irradiated PWR Fuel." Journal of Nuclear Materials. 126:132-143.

Manzel, R., F. Sontheimer, and R. Wurtz. 1984. "The Radial Distribution of Fission Gases and Other Fission Products in Irradiated PWR Fuel." Journal of Nuclear Materia1s. 126:132-143.

Matzke, Hj. and C. Ronchi. 1977. "Fuel Properties of Advanced Fuels (U,Pu)CN Important for Out-of-Pile and In-Pile Kinetics." International Meeting on Advanced LMFBR Fuels. Tucson, AZ.

Neeb, K. H., W. Schweighofer, and R. Wurtz. 1981. "Experimental Methods for Investigations on Light Water Reactor Fuels." Journal of Nuclear Materials. $97: 165-172$. 
Notely, M. J. P. and I. J. Hastings. 1978. A Microstructure-Dependent Model for Fission Product Gas Release and Swelling in $\mathrm{VO}_{2}$ Fuel. AECL-5838, ChaTk River Nuclear Laboratories, Chalk River, Ontario, Canada.

Peehs, M., R. Manzel, W. Schweighofer, W. Maas, E. Haas, and R. Wurtz. 1981. "On Behavior of Cesium and Iodine in Light Water Reactor Fuel Rods." Journal of Nuclear Materials. 97:157-164.

Peehs, M., R. Kuhnel, G. Kaspar. 1982. "Discussion of Spent LWR Fuel Properties in Relation to Actual Long-Term Storage Concepts." Transactions of the American Nuclear Society. 40:135.

Sari, C., C.T. Walker, and G. Schumacher. 1979. "Solubility and Migration of Fission Product Barium in 0xide Fuel." Journal of Nuclear Materials. 79:255-259.

Thomas, Jr., C. C., Cobb, D. D. and C. A. Ostenak (LANL), 1981. "Spent Fuel Composition: A Comparison of Predicted and Measured Data." Transactions of the American Nuclear Society. 39:323-325.

Turnbu11, J. A. and C. A. Friskney. 1978. "The Relation Between Microstructure and the Release of Unstable Fission Products During High Temperature Irradiation of Uranium Dioxide." Journal of Nuclear Materials. $71: 238-248$.

Wasywich, K. M., J. D. Chen, K. I. Burns, and D. G. Boase. 1982. "The Characterization of Irradiated Candu Fuel Bundles Stored in Concrete Canisters at WNRE (Whiteshe11 Nuclear Research Establishment)." InternationaT Conference on Radioactive Waste Management. pp. 452-457.

Yang, Rosa L. and D. R. 0lander. 1981. "Behavior of Metallic Inclusions in Uranium Dioxide." Nuclear Technology. 54:223-233.

Zimmerman, H. 1978. "Investigations of Swelling and Fission Gas Behavior in Uranium Dioxide." Journal of Nuclear Materials. 75:154-161.

OUT-OF-REACTOR STORAGE EXPERIENCE

The informal WPP library at PNL contains the following articles on the behavior of spent fuels in dry and wet (pool) storage. These articles may be of particular importance if it is deemed necessary to predict the integrity of the spent fuel cladding (i.e. a barrier to the release of radionuclides) over a geologic time period.

Bailey, H. J., and A. B. Johnson, Jr. 1984. Surveillance of LWR Spent Fuel in Wet Storage. EPRI NP-3765, Electric Power Research Institute, Pa10 A1to, CA. 
Bailey, W. J. and A. B. Johnson, Jr. 1983. Wet Storage Integrity Update. PNL-4726, Pacific Northwest Laboratory, Richland, WA.

Bonilla, C. F. 1974. "Preface: Advanced Course in In-Reactor Behavior of Water Reactor Fuels and its Influence on Design, Manufacture and Operation." Nuclear Engineering and Design, Vol. 33, p. 93.

Bosi, D. M. 1981. An Assessment of Spent Fuel Structural Integrity Under Disposa? Cycle Conditions. HEDL-TME 80-84, Hanford Engineering Development Laboratory, Richland, WA.

Bosi, D. M. 1980. An Assessment of Spent Fuel Structural Integrity Under Dis posal Cycle Conditions. HEDL-TC-1860, Hanford Engineering Development Laboratory, Richland, WA.

Bradley, E. R., W. J. Bailey, A. B. Johnson, Ur., and L. M. Lowry. 1981. Examination of Zircaloy-Clad Spent Fuel After Extended Pool Storage. PNL-3921, Pacific Northwest Laboratory, Richland, WA.

Eickelpasch, N., H. Wilstermann, Gundremmigen, W. Fettel, and D. Hubscher, Offenbach. 1981. "Radioactivity Releases from fuel Elements Stored in the KRB-A Storage Pool Over Prolonged Periods of Time." Atomiwirtschaft Atomtechnik. 26(4):242-246.

Einziger, R. E. and R. L. Fish. 1982. Characterization of LWR Spent Fuel Rods used in the NRC Low-Temperature Whole Rod and Crud Performance Test. NUREG/CR-2871, HEDL-TME 82-27, RW., Hanford Engineering Development Laboratory, Richland, WA.

Einziger, R. E., and R. Kohli. 1984. Low-Temperature Rupture Behavior of Zircaloy Clad Pressurized Water Reactor Spent Fuel Rods Under Dry Storage Conditions. HEDL-740D, Hanford Engineering Development Laboratory, Richland, WA.

Einziger, R. E., S. D. Atkin, D. E. Stellrecht, and V. Pasupathi. 1981. High Temperature Post Irradiation Materials Performance of Spent Pressurized Water Reactor Fuel Rods Under Ory Storage Conditions. HEDL SA-2484 FP, Hanford Engineering Development Laboratory, Richland, WA.

Einziger, R. E. and J. A. Cook. 1984. LWR Spent Fuel Dry Storage Behavior at $229^{\circ} \mathrm{C}$. Hanford Engineering Development Laboratory. NUREG/CR-3708, HEDL-TME 84-17, RJ, Hanford Engineering Development Laboratory, Richland, WA.

Einziger, R. E, and 0. M. Bosi. 1981. "Zircaloy Cladding--Tough Containment for Spent Fuel Storage." Presented at the 1981 Annual Meeting of the American Nuclear Society, HEDL-SA-2325 FP, Miami, FL.

Einziger, R. E., R. L. Fish, and R. L. Knecht. 1982. A Technical Description of the NRC Long-Term Whole Rod and Crud Performance Test. NUREG/CR-28-89, Hanford Engineering Development Laboratory, RichTand, WA. 
Garzarolli, F., R. von Jan, and H. Stehle. 1979. "The Main Causes of Fuel Element Failure in Water-Cooled Power Reactors." Atomic Energy Review. Vol. 17, No. 1, p. 31-128.

Johnson, Jr., A. B. 1978. Impacts of Reactor-Induced Defects on Spent Fue? Storage, PNL-SA-6917, Pacific Northwest Laboratory, Richiand, WA.

Johnson, Jr., A. B., E. R. Gilbert and R. J. Guenther. 1983. Behavior of Spent Nuclear Fuel and Storage System Components in Dry Interim Storage. PNL-4189 Rev. 1, Pacific Northwest Laboratory, Richland, WA.

Johnson, Jr., A. 8. and E. R. Gilbert: 1984. "Current Status of Fuel Degradation Studies in Dry Storage." Presented at the Seminar on Spent Fuel Storage Technology, Pacific Northwest Laboratory, PNL-SA-11894, Richland, WA.

Johnson, Ur., A. B. and W. J. Bajley. 1981. Assessment of Interim Storage of Spent High-Burnup LWR Fuel(a). PNL-SA-9697, Pacific Northwest Laboratory, Richland, WA.

Johnson, Jr., A. B., P. A. Pankaskie, and E. R. Gilbert. 1982. Spent Fue? Behavior in Dry Storage, PNL-SA-10248, presented at the 0ECD Specialist Workshop on Techniques for the Dry Storage of Spent Fuel Elements, Madrid, Spain, Pacific Northwest Laboratory, Richland, WA.

Johnson, Jr., A. B., W. J. Bailey, E. R. Bradley, S. M. Bruemmer, and D. C. Langstaff. 1981. Annual Report--FY 1980 Spent Fuel and Fuel Pool Component Integrity. PNL-3868, Pacific Northwest Laboratory, Richiland, WA.

Johnson, Jr., A. G., W. J. Bailey, E. R. Bradley, and D. C. Langstaff. 1980. Significance of Shippingport and Connecticut Yankee Fuel Examinations to Extended Water Storage of LWR Fue1. PNL-SA-8833, Pacific Northwest Laboratory, Richland, WA.

Langstaff, D. C., W. J. Bailey, A. B. Johnson, Jr., M. P. Landow, V. Pasupathi and R. W. Klingensmith. 1982. Examination of Stainless Steel-Clad Connecticut Yankee Fuel Assembly S004 After Storage in Borated Water. PNL-3828, Pacific Northwest Laboratory, Richland, WA.

Pasupathi, V., and D. Stahl. 1982. Expected Performance of Spent LWR Fuel. Under Dry Storage Conditions. EPRI NP-2735, Electric Power Research Institute, Palo Alto, CA.

Peehs, M., D. Jorde, H. Unger, and J. Fleisch. 1984. "Results of a Long-Term Wet Storage Demonstration Test with Intact and Operational Defective LWR Fuel Rods." Nuclear Engineering and Design. 83:67-73.

Sachs, R. G., J. A. Kyger. 1975. Light-Water-Reactor Safety Research Program: Quarterly Progress Report. ANL 75-58, Argonne National Laboratory, Argonne, IL. 
Stah1, D., M. P. Landow, R. J. Burian, and V. Pasupathi. 1986. Spent Fuel Behavior Under Abnormal Thermal Transience During Dry Storage, PNL-5456. Pacific Northwest Laboratory, Richland, WA.

Woodley, R. E. 1983. Considerations Relevant to the Dry Storage of LWR Fuel Rods Containing Water. NUREG/CR-3658, Hanford Engineering Development Laboratory, Richland, WA.

Zima, G. E. 1979. An Evaluation of Potential Chemical/Mechanical Degradation Process Affecting Fuel and Structural Materials Under Long-Term Water Storage. PNL-2379, Pacific Northwest Laboratory, Richland, WA. 


\section{DISTRIBUTION}

No. of

Copies

\section{OFFSITE}

10 DOE/Office of Scientific and Technical Information

5 DOE Office of Civilian Radioactive Waste Management Forrestal Building Washington, DC 20585

ATTN: D. H. Alexander, (RW-232)

M. W. Freí, (RW-231)

S. H. Kale, $(\mathrm{RW}-20)$

C. E. Kay, (RW-2)

R. Stein, (RW-23)

A. T. Clark

Division of Fuel Material Safety

Nuclear Regulatory Commission

Washington, DC 20555

G. L. Sjoblom

Environmental Protection Agency

Office of Radiation Programs

401 M Street, S.W.

Washington, DC 20460

J. M. McGough

DOE Albuquerque Operations Office

P.0. Box 5400

Albuquerque, NM 87185

8 Atomic Energy of Canada Limited Whiteshell Nuclear Research Establishment

Pinawa, Manitoba, Canada

ROE $1 \mathrm{LO}$

ATTN: B. W. Goodwin

L. H. Johnson

R. J. Lemire

D. W. Shoesmith

S. Stroes-Gascoyne

S. Sunder

J. Tajt

Technical Library
No. of

Copies

T. H. Pigford

University of California

Berkeley, CA 94720

Lars Werme

SKBF-Swedish Nuclear Fuel

Supply Co.

Division KBS

Box 5864

S-102 48 Stockholm, Sweden

L. D. Ramspott

Lawrence Livermore National Laboratory

University of California

P.D. Box 808

Livermore, CA 94550

J. W. Roddy

Oak Ridge National Laboratory

P.0. Box $Y$

Dak Ridge, TN 37830

M. J. Plodinec

E. I. du Pont de Nemours $\&$ Company, Inc.

Savannah River Laboratory

Aiken, SC 29801

G. F. Thomas

Ontario Hydro Research Division

800 Kipling Ave.

Toronto, Ontario, Canada

M8Z 554

Pergamon Journals, Inc. Journal Permissions Dept. Maxwell House, Fairview Park Elms ford, NY 10523

2 S. A. Simonson

8 Waban St.

Natick, MA 01760 
No. of

Copies

2 Studsvik Energiteknik

Nykoping S-611 82

Sweden

ATTN :

H. Christensen

R. S. Forsyth

J. Bruno

Royal Institute of Technology Dept. of Inorganic Chemistry Stockholm S-100 44

Sweden

B. Grambow

Hahn-Meitner-Institut Berlin

Glienickerstrasse 100

D-1000 Berlin 39

Federal Republic of Germany

$R$. Wuertz

Kraftwerk Union Aktiengesel 1 schaft

D-8757 Karlstein

Federal Republic of Germany

K. $011 i l a$

Technical Research Center of Finland

Imatra Power Company

P. 0. Box 138

SF-00101 Helsinki 10

Finland
No. of

Copies

ONSITE

3 DOE Richland Operations Office

D. C. Langstaff

J. J. Sutey

G. W. Rosenwald

31 Pacific Northwest Laboratory

M. J. Apted

D. J. Bradley

D. G. Coles

R. E. Einziger

W. J. Gray

R. J. Guenther

M. R. Kreiter

W. L. Xuhn

S. C. Marschman

J. E. Mendel

L. G. Morgan

P. W. Reimus (10)

D. M. Strachan

A. E. Van Lujk

C. N. Wilson

Technical Report Files (5)

Publishing Coordination (2) 